UNIVERSIDADE DE SÃO PAULO

FACULDADE DE ARQUITETURA E URBANISMO

ALICE DE OLIVEIRA VIANA

Gottfried Semper e o Ornamento em Arquitetura

São Paulo

2017 


\section{Gottfried Semper e o Ornamento em Arquitetura}

Tese apresentada ao Núcleo de PósGraduação da Faculdade de Arquitetura e Urbanismo da Universidade de São Paulo para obtenção do título de Doutor em Ciências, junto ao Programa de Arquitetura e Urbanismo

Área de Concentração: História e Fundamentos da Arquitetura e do Urbanismo

Orientador: Prof. Dr. Ricardo Marques de Azevedo 
AUTORIZO A REPRODUÇÃO E DIVULGAÇÃO TOTAL OU PARCIAL DESTE TRABALHO, POR QUALQUER MEIO CONVENCIONAL OU ELETRÔNICO, PARA FINS DE ESTUDO E PESQUISA, DESDE QUE CITADA A FONTE.

E-MAIL DA AUTORA: alice_viana@yahoo.com.br

Viana, Alice de Oliveira

V614g Gottfried Semper e o ornamento em arquitetura / Alice de Oliveira Viana. -- São Paulo, 2017. 183p.: il.

Tese (Doutorado - Área de Concentração: História e Fundamentos da Arquitetura e do Urbanismo) - FAUUSP. Orientador: Ricardo Marques de Azevedo

1.Ornamentação 2.Arquitetura 3.Estilo 4.Ordem 5.Semper, Gottfried, 1803-1879 I.Título 
Nome: VIANA, Alice de Oliveira.

Título: Gottfried Semper e o Ornamento em Arquitetura

Tese apresentada ao Núcleo de PósGraduação da Faculdade de Arquitetura e Urbanismo da Universidade de São Paulo para obtenção do título de Doutor em Ciências, junto ao Programa de Arquitetura e Urbanismo

Aprovado em

Prof.Dr.

Instituição:

Julgamento:

Prof.Dr.

Instituição:

Julgamento:

Prof.Dr.

Instituição:

Julgament:

Prof.Dr.

Instituição:

Julgament:

Prof.Dr.

Instituição:

Julgamento: 
Para Gu,

Jana, Jack e Johnny. 


\section{AGRADECIMENTOS}

Ao José Gustavo Bononi, meu amor e companheiro de todas as horas, por não ter me deixado desistir e pelas tristezas e alegrias compartilhadas nestes quatro anos.

À minha família, pelo carinho e consideração. À Letícia Bononi, pelo apoio e auxílio prestativo em São Paulo.

Ao professor Ricardo, pela orientação dedicada e sempre tão esclarecedora, pelo conhecimento compartilhado gentilmente e pela confiança depositada em $\operatorname{mim}$.

Aos professores membros da banca de qualificação, Mário Henrique S. D'Agostino e Jens Baumgarten pelas valiosas contribuições, e aos professores da disciplina Preceptivas Artísticas, Andrea Loewen e Luciano Migliaccio, os quais, juntamente com prof. Ricardo e prof. Mário Henrique S. D'Agostino, possibilitaram dois semestres de rico aprendizado e aprofundamento teórico.

À Barbara von Orelli-Messerli, supervisora do doutorado sanduíche no Kunsthistorisches Institut da Universidade de Zurique, pela atenção e orientação quanto aos caminhos a seguir.

À amiga Elena Chestnova, pelas conversas agradáveis e informais, pelas interlocuções sobre Gottfried Semper e pelo material gentilmente cedido.

Aos funcionários do Semperarchiv da ETH, principalmente Filine Wagner e Muriel Pérez, tão prestativas e cuidadosas na organização deste valoroso acervo de Arquitetura.

À Universidade do Estado de Santa Catarina, por ter possibilitado minha dedicação integral à tese por dois anos e pelo incentivo à capacitação dos docentes.

Aos vários colegas, amigos e alunos que, por via direta ou não, me permitiram refletir sobre e questionar aspectos da tese.

À CAPES, pela bolsa de doutorado sanduíche na Suíça entre outubro de 2015 e janeiro de 2016. 
"Todas as artes começaram pelo necessário".

Goethe, Arte e artesanato. In: Escritos sobre arte, 2008, p.91.

"Na costura manifesta-se, em sua expressão mais simples, mais original e ao mesmo tempo mais compreensível, o mais importante e primeiro axioma da prática artística - a regra, a saber, de fazer da necessidade uma virtude".

Gottfried Semper, Der Stil, volume I, 1860, p.78-9, grifos do autor. 


\section{RESUMO}

A tese investiga o conceito de Ornamento no arquiteto e teórico Gottfried Semper (1803-1879), quem elabora, em meados do século XIX, importante teorização deste elemento arquitetônico. Destina-se a demonstrar que, em meio a um processo de depreciação semântica vigente na época, Semper procura restabelecer o status quo do Ornamento, consagrando a ele uma importância fundamental para os indivíduos e suas instituições sociais. Os vínculos tradicionais entre Ornamento e noções clássicas como Estilo e ordem são reforçados e atualizados pelo autor, considerando o contexto da época. Para este estudo, a investigação considerou dois momentos. Primeiramente, adotouse um recuo temporal, trabalhado na longa duração, com o intuito de se apresentar um quadro sintético de noções e conceitos interdependentes que estruturaram o conceito de Ornamento na Tradição Clássica. Aqui a escrita foi organizada a partir da observação atenta às transformações dos sentidos atribuídos ao termo, aos conceitos que giraram em torno dele e o constituíram como um componente imprescindível do que se compreende por Arquitetura na Tradição. Em um segundo momento analisou-se o conceito de Ornamento em Semper em meio ao contexto europeu de meados dos oitocentos, tendo em vista o enfraquecimento da legitimidade da Tradição Clássica e as implicações resultantes do desenvolvimento da indústria moderna. Considera-se que os escritos deste autor, na medida em que procuram atualizar o conceito de Ornamento, evidenciam parte do contexto de crise da ornamentação em Arquitetura, que, diferentemente do que costuma colocar a historiografia tradicional, iniciou-se bem antes da aurora do moderno. O Ornamento em Semper deve ser compreendido como um conceito que opera dentro da disciplina Arquitetura e que faz parte dos esforços do autor em reorganizá-la em meados do século XIX.

Palavras-chave: Ornamento. Gottfried Semper. Arquitetura. Estilo. Ordem. 


\begin{abstract}
This thesis investigates the concept of Ornament in the writings of the architect and theorist Gottfried Semper (1803-1879), who put forth an important theory about this architectural element in the middle of the nineteenth century. It aims to show that Semper tried to restore the status quo of the Ornament in the midst of semantic devaluation, thereby granting the Ornament essential prominence in social institutions and to individuals. This thesis also shows that the author reinforces and updates traditional connections between the Ornament and classical notions, such as Style and Order. In order to accomplish the above, this study considered two moments. Firstly, the concept of Ornament in Classical Tradition was presented using temporal regression in a long duration structure; the writing about this moment is organized according to transformations in the meanings attributed to the term Ornament, and to the concepts that revolved around it and constituted essential components of Architecture in Tradition. The second moment is that in which Semper's concept of Ornament is analyzed throughout the mid-nineteenth century European context; in this view, the legitimacy of Classical Tradition is weakened, due in part to the development of modern industry. In seeking to update the concept of Ornament, Semper's writings make explicit the crisis of Ornamentation in Architecture, which began well before the dawn of modern time, unlike traditional historiography says. This thesis argues that the Semperian Ornament should be understood as a concept that operates within the discipline of Architecture and is part of the author's efforts to reorganize it in the mid-nineteenth century.
\end{abstract}

Keywords: Ornament. Gottfried Semper. Architecture. Style. Order. 


\section{ZUSAMMENFASSUNG}

Die Arbeit untersucht den Begriff "Ornament" in den Schriften des Architekten und Theoretikers Gottfried Semper (1803-1879), der dieses Element der Architektur der Mitte des neunzehnten Jahrhunderts in einer wichtigen Theorie erarbeitet. Es will nachweisen, dass Semper in der Mitte eines Prozesses semantischen Abwertung den status quo Ornament wiederherzustellen versucht, indem er ihm eine grundlegende Bedeutung für die Menschen und ihre sozialen Instituitionen widmet. Traditionelle Verbindungen zwischen Ornament und klassischen Begriffen wie Stil und Ordnung werden gestärkt und vom Verfasser aktualisiert, indem er den Kontext seiner Zeit berücksichtigt. Für diese Arbeit betrachtet die Forschung zwei Momente. Erstens wurde eine auf lange Dauer zeitliche Rückkehr angenommen, um eine Übersicht der Begriffe und voneinander abhängigen Vorstellungen zu präsentieren, die das Begriff des Ornaments in der klassischen Tradition strukturieren. Hier wurde auf Grund der Beobachtung auf die Veränderung der Bedeutungen des Worts, sowie auf die Begriffe, die sich um auf Ornament als eine wesentliche Komponente beziehen und bilden, was als Architektur in der Tradition verstanden wird, aufmerksam gemacht. In einem zweiten Moment wurde Semper's Begriff des Ornaments im europäischen Kontext der Mitte des neuzehnten Jahrhunderts analysiert, indem man die Schwächung der Legitimität der klassischen Tradition und die daraus resultierenden Auswirkungen der modernen industriellen Entwicklung berücksichtigt. Es wird betrachtet, dass die Schriften Semper's, insofern sie den Begriff „Ornament“ zu aktualisieren beabsichtigen, zeigen der Kontext der Krise der architektonischen Verzierung, was, anders als der traditionellen Architekturgeschichtsschreibung bestätigt, früher als die Morgendämmerung der Moderne anfing. Semper's Ornament soll als ein Begriff des Fachgebietes Architektur verstanden werden, und als Teil der Bemühungen des Verfasser in der Mitte des neunzehnten Jahrhunderts dieses Fachgebiet neu zu organisieren.

Schlüsselwörter: Ornament. Gottfried Semper. Architektur. Stil. Ordnung. 


\section{LISTA DE FIGURAS}

\section{Capítulo $1 \quad$ O Ornamento na Tradição Clássica}

$\begin{array}{lll}\text { Figuras } 1 \text { e } 2 \text { Disposição "destacada" da coluna. } & \text { p. } 44\end{array}$

Figura $3 \quad$ Prancha "Des Ornemens de l'Architecture", do livro p.46 de André Félibien.

$\begin{array}{lll}\text { Figura } 4 & \text { Gravura das cinco ordens de Sebastiano Serlio. } & \text { p.49 }\end{array}$

\section{Capítulo $2 \quad 0$ Ornamento na origem das artes}

Figura 5

Gravura da obra de Gustav Klemm, representando

p.72 as tatuagens faciais de homens primitivos.

Figura 6

Coroa de folhas, desenho de Semper.

Figuras 7 e $8 \quad$ Exemplos de nó, desenhos de Semper.

p.82

Figura 9

Ilustração do Caduceu de Hermes, desenho de

p.82 Semper.

Figura 10

Exemplos de trançados, à esquerda, um exemplo p.84 de três fios e à direita, um de quatro. Desenhos de Semper.

Figuras 11 e 12 Exemplos de trabalhos em trama, cuja variedade permite observar a possibilidade de ricas composições. Desenhos de Semper.

Figura 13

Cabana caribenha observada na Exposição industrial de Londres de 1851. Desenho de Semper.

p.91

\section{Capítulo 3}

\section{Ornamento e Estilo}

Figura 14

Cordão de pérolas e nós e sua estilização em uma moldura ornamental. Desenhos de Semper.

Figuras 15 a 17 À direita dois tipos de cordões, abaixo uma coroa de flores e acima uma sequência de ondas. À esquerda, um cordão marcando o pescoço de um vaso cerâmico. Desenhos de Semper.

Figuras 18 a 20 À direita tipos de faixas e à esquerda sua

p.122 exemplificação nos toros da base jônica. Desenhos de Semper. 
Figuras 21 e 22 Exemplos de cordões estilizados, usados na p.122 arquitetura. Desenhos de Semper.

Figuras 23 e 24 Edificação coroada com ameias e franjas de uma p.123 vestimenta medieval. Desenhos de Semper.

Figuras 25 e 26 Castelo assírio com ameia e franjas de um dossel p.123 estilo Luis XIV. Desenhos de Semper.

Figura 27

Anforas das premiações panatenaicas exibindo como decoração cordões e faixas. Desenhos de Semper.

Figura 28

Representação de piso de mosaico do pronau do p.124 templo de Zeus Olímpico em Atenas. Desenho de Semper.

Figura 29

Representação de um piso de mosaico romano.

p.125 Desenho de Semper.

Figura 30

Vaso etrusco da Toscana. Desenho de Semper.

Figura 31

Representação de um "espírito protetor" assírio.

p.132 Desenho de Semper.

Figura 32

Representação assíria de uma caça ao leão real.

p.133 Desenho de Semper.

Figura 33

Padrão de tapete assírio gravado em pedra.

p.133 Desenho de Semper.

Figura 34

Exemplo de "tapete de pedra" assírio.

Figuras 35 e 36 Hábito do soberano assírio, com borlas e cadilhos. p.134 Desenhos de Semper.

Figura 37

Tríglifos como borda de um piso de mosaico. p.135 Desenho de Semper.

Figura 38

Representação de leão em ladrilhos coloridos, palácio de Susa, antigo império persa.

Figura 39

Sítula egípcia. Desenho de Semper.

\section{Capítulo $4 \quad 0$ Ornamento como ordem}

Figuras 40 e 41 Carros de combate egípcio e assírio. Desenhos de p.144 Semper. 
Figura 42 Coluna egípcia com capitel de botão de lótus. p.146 Desenho de Semper.

Figura 43 Perfis de cima indicando tipos de carregamento. p.150

Figura 44 Tipos de óvalo-e-dardo e folha-e-dardo, em vista e p.150 em perfil.

Figura $45 \quad$ Estudos das bases das ordens e das curvaturas dos p.151 perfis.

Figura 46

Perfis de curvatura dupla (a) e de curvatura simples p.152

(b). Motivos folha-e-dardo (a) e óvalo-e-dardo (b).

Figura 47

Tipos de folha-e-dardo (esq.) e óvalo-e-dardo com

p.153 contas de rosário (dir.). Desenho de Semper.

Figura 48

Prancha de desenhos de Semper mostrando seus

p.156 estudos da policromia clássica.

Figuras 49 e 50 Coluna e capitel egípcios com motivos vegetais. p.158 Desenhos de Semper.

Figura 51

Capitel de coluna persa. Desenho de Semper.

p. 160

Figura 52

Cadeira assíria, com formas aludindo ao dorso e às

p. 160 patas de animais. Desenho de Semper.

Figura 53

Hídria grega. Desenho de Semper.

p.165 


\section{SUMÁRIO}

INTRODUÇÃO. 14

I - O conceito de Ornamento em Arquitetura na Tradição

10 ORNAMENTO NA TRADIÇÃO CLÁSSICA 23

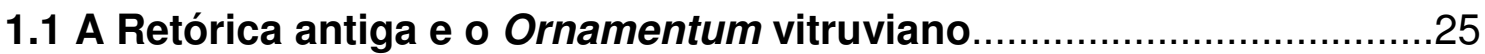

1.2 O Ornamentum em Alberti e a coluna como Ornamento.......................39

1.3 Ordem arquitetônica como Ornamento: normatividade e crítica.

II - O Ornamento semperiano

2 O ORNAMENTO NA ORIGEM DAS ARTES

2.1 Adorno e ritual: a constituição da individualidade 68

2.2 A divisória decorada e a cabana primitiva: a vida coletiva em família 85

2.30 revestimento do corpo social: a arquitetura monumental. 92

3 ORNAMENTO E ESTILO. 100

3.1 Estilo como correspondência a uma ideia.......................................105

3.2 O Ornamento é a linguagem do Estilo...........................................115

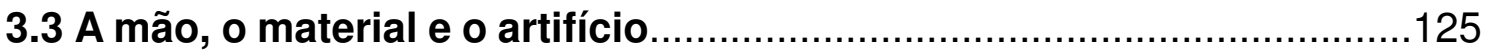

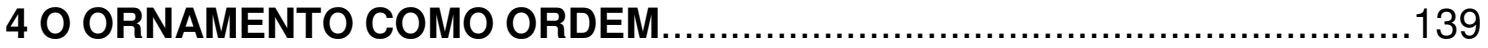

4.1 A união do princípio decorativo ao princípio estrutural......................141

4.2 Ornamento como símbolo estrutural da Arquitetura...........................148

4.3 Unidade entre beleza, aspectos estruturais e de utilidade...................157

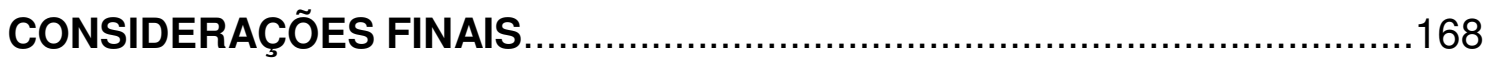

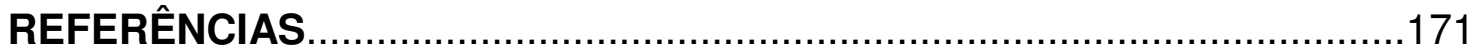




\section{INTRODUÇÃO}

Os compromissos do discurso científico com a presunção de verdade muitas vezes camuflam as fragilidades e incertezas do processo de seleção de que se vale a pesquisa histórica em Arquitetura. Exemplo paradigmático desta condição é o caso do arquiteto e teórico hamburguês Gottfried Semper (1803 1879). Não obstante a autoria de obras monumentais em várias cidades da Europa central, como também de vasta produção teórica - coroada com sua opus magnum, Der Stil in den technischen und tektonischen Künsten ${ }^{1}$-, é surpreendente o fato de Semper, que já durante sua atuação profissional na segunda metade do século XIX foi reconhecido como "mestre da teoria e prática alemã", ${ }^{2}$ ter se tornado "quase completamente esquecido [...] nas explicações de princípios do século XX sobre este período" (o século XIX). ${ }^{3}$

Desde a década de sessenta do século $X X$, alguns estudos procuram reverter não somente o "esquecimento", 4 como também as leituras reducionistas ${ }^{5}$ e, muitas vezes deterministas que essa escrita da história da

\footnotetext{
1 O título completo é Der Stil in den technischen und tektonischen Künsten, oder, Praktische Aesthetik. Ein Handbuch für Techniker, Künstler und Kunstfreund. A obra foi publicada em dois volumes, o primeiro em 1860 (Frankfurt: Verlag für Kunst und Wissenschaft, 1860, v.l) e o segundo em 1863 (München: Friedrich Bruckmann's Verlag, 1863, v.lI).

2 "... master of German theory and practice". MALLGRAVE, Harry Francis. Gottfried Semper. architect of the nineteenth century. New Haven: Yale University Press, 1996, p.355.

3 “....almost entirely forgotten [...] by early twentieth-century explanations of this period...". Id.Ibid., p.355.

${ }^{4}$ Nos escritos basilares sobre história da Arquitetura moderna, particularmente nas principais obras de Sigfried Giedion e Nikolaus Pevsner, a menção a Semper aparece somente em breves trechos e notas esparsas. Pevsner somente menciona a Ópera de Dresden de autoria de Semper, caracterizando-a como um projeto neorenascentista e em outro momento faz uma breve menção ao texto Wissenschaft, Industrie und Kunst, escrito por Semper em meados do século. Cf PEVSNER, Nikolaus. Os Pioneiros do Desenho Moderno: de William Morris a Walter Gropius. Trad. João Paulo Monteiro. SP: Martins Fontes, 2002. Já Giedion menciona Semper em três momentos. Um deles é em uma nota de rodapé, na qual o nome do teórico é associado às discussões sobre policromia no século XIX. Em outro momento, Semper é brevemente mencionado como tendo se manifestado sobre a estrutura em ferro do Jardin des Plantes em Paris. E por último, Giedion afirma rapidamente ter sido Semper um dos fundadores da primeira escola de inglesa desenho, de 1851, e cita um trecho do texto Wissenschaft, Industrie und Kunst, no qual o teórico descreve as artes industriais americanas. GIEDION, Sigfried. Espaço, Tempo e Arquitetura. O desenvolvimento de uma nova tradição. Trad. Alvamar Lamparelli. SP: Martins Fontes, 2004.

${ }^{5}$ Hendrik P. Berlage não somente associa as ideias de Semper ao "racionalismo estilístico" de Viollet-leDuc, como também sustenta ser a obra Der Stil responsável por "ensinar a evolução materialista da arte", ponto de vista que hoje é avaliado como distorcido, constituindo uma leitura superficial de seus escritos. Cf BERLAGE, Hendrik Petrus. "Some reflections on Classical Architecture" (1908) in: MALLGRAVE, Harry Francis (ed.). Hendrik Petrus Berlage: Thoughts on Style, 1886-1909. Trans. lain Boyd White and Wim de Wit. Los Angeles: Getty Research Institute, 1996, p.264. Tradução nossa de: “... [Der Stil...] teaches the materialist evolution of art'. Também Hermann Muthesius, em sua obra Stilarchitektur und Baukunst (1902), apesar de caracterizar o autor do Der Stil como "o brilhante Gottfried Semper", estabelece-o também como "a figura mais importante do movimento historicista na Arquitetura" na Alemanha, movimento que Muthesius associa depreciativamente à arquitetura dos estilos, marcada por um formalismo estilístico e ornamental do passado que, segundo ele, deveria ser superado. MUTHESIUS, Hermann. Style Architecture and BuildingArt, transformations of Architecture in the nineteenth century and its present conditions. Trans. Stanford Anderson. Los Angeles: Getty Research Institute, 1994, p.68. Tradução nossa de: ... "the brilliant Gottfried Semper [...] the most important figure in the historicist movement in architecture".
} 
Arquitetura construiu acerca de Semper. ${ }^{6}$ Uma rica literatura sobre este autor veio desde então se formando, considerando as contribuições que ele trouxe a uma variedade de temas que orbitam em torno das Artes, sobretudo da Arquitetura. ${ }^{7}$

\section{Um interesse da literatura recente que aborda o trabalho de Gottfried} Semper é o tema do Ornamento, ${ }^{8}$ tratado em diversos escritos deste autor e que se apresenta como objeto de estudo da presente investigação de tese. Após sua rejeição pela teoria e prática da Arquitetura no período de vigência do moderno,

\footnotetext{
${ }^{6}$ No campo da Teoria e História da Arte, Lionello Venturi foi quem apresentou uma visão generalizante, além de condenadora, ao que ele avaliava ser o pensamento teórico de Semper. Em sua História da Crítica de Arte, de 1936, Venturi não somente afirma que Semper conferiu um "caráter universal e algumas bases estéticas ao movimento técnico", como também o critica pelo "caráter repugnante de tal concepção materialista da arte". Tradução nossa conforme versão em espanhol: "...carácter universal y unas bases estéticas al movimiento técnico" e "...carácter repugnante de dicha concepción materialista del arte...". VENTURI, Lionello. Historia de la crítica de arte. Barcelona: Debolsillo, 2004, p.256.

${ }^{7}$ Sokratis Georgiadis traça um importante panorama do que ocorreu com as análises do legado de Semper nas primeiras décadas que se seguiram à Segunda Guerra Mundial (GEORGIADIS, Sokrates. Sempers schwierige Rückkehr aus dem zweiten Exil. In: Werk, Bauen + Wohnen, n.4, 1992, pp.61-2). Segundo ele, a situação de desinteresse pelos escritos deste autor, de um modo geral, se manteve na Alemanha Ocidental; foi em Dresden - à época uma cidade da República Democrática Alemã - e em Zurique, onde aos poucos foram aparecendo pesquisas. Se em Dresden, consoante coloca Georgiadis, forma-se um "campo de exercício privilegiado de uma historiografia histórico-materialista", contribuindo de certo modo com a continuidade deste tipo de abordagem da obra teórica de Semper, é em Zurique que se constitui gradativamente um centro de produção não somente de novas temáticas, mas principalmente de abordagens e pontos de vista renovados sobre este autor (Tradução de "...zum privilegierten Übungsfeld historisch-materialistischer Geschichtsschreibung"..lbid., p.61). Isto se deve sobretudo à iniciativa do Institute für Geschichte und Theorie der Architektur (gta) do Eidgenössische Technische Hochschule (ETH) da Universidade de Zurique em sistematizar e classificar os escritos e desenhos de Semper, os quais haviam sido reunidos e preservados por seus ex-alunos. A partir da catalogação de seus textos e desenhos foram publicadas importantes obras que, ao trazer manuscritos e desenhos inéditos, bem como parte da biografia de Semper, facilitaram a pesquisa acadêmica: Gottfried Semper: zeichnerischer Nachlass an der ETH-Zürich, de Martin Fröhlich (Basel: Birkhäuser, 1974), Gottfried Semper im Exil e Gottfried Semper: theoretischer Nachlass an der ETH-Zürich, estas últimas de autoria de Wolfgang Herrmann (Basel: Birkhäuser, 1978 e Basel: Birkhäuser, 1981). Logo em seguida à publicação destas obras, surgem estudos em inglês que possibilitaram maior difusão da obra de Semper; um deles é Gottfried Semper: in search of architecture, compilação seguida da tradução dos dois livros de Herrmann citados anteriormente. Também dignos de nota são o estudo de Joseph Rykwert sobre Semper, divulgado pelo texto Semper and the conception of style (RYKWERT, Joseph. Semper and the conception of style. In: . The necessity of artifice: ideas in architecture. New York: Rizzoli, 1982, pp.123-130) e a tese de Doutorado de Harry Francis Mallgrave, The idea of style: Gottfried Semper in London (Doutorado em Arquitetura apresentado para as Graduate Faculties of the University of Pennsylvania, Filadélfia, 1983).

${ }^{8}$ Além desta temática do Ornamento, podem ser citadas, por exemplo, pesquisas que vêm investigando o legado ou as relações de Semper para com o discurso de outros teóricos (ZEISING, Andreas. Haus und Herd: Wagner, Semper und die Urhütte. In: ZEISING, Andreas; IMORDE, Joseph (Hrsg.) Wahn und Wirkung. Perspektiven auf Richard Wagner. Siegen: Universitätsverlag Siegen, 2014; também OECHSLIN, Werner. Gottfried Semper und Jacob Burckhardt: der unterschiedliche Blick auf die Renaissance. In: BEYER, Andreas; TÖNNESMANN, Andreas; MARKSCHIES, Alexander (Hrsg.) Zeitschrift für Kunstgeschichte. Müncher: Deutscher Kunstverlag, 2009, n.72, 1, pp.99-110.); a importância de seus escritos para a constituição dos museus, especialmente os de artes aplicadas na Europa (LEONI, Claudio. Art, production and market conditions Gottfried Semper's historical perspective on commodities and the role of museums. In: WOODFIELD, Richard (ed.). Journal of art historiography, n.11, Dec. 2014; cf. também HOUZE, Rebecca. Hungarian nationalism, Gottfried Semper and the Budapest Museum of Applied Art. In: Studies in the decorative arts. Chicago: The university of Chicago press, 2009, v.16, n.2, pp.7-38.); as relações entre historiografia e "estética prática" em sua obra (HILDEBRAND, Sonja. Concepts of creation: historiography and design in Gottfried Semper. In: WOODFIELD, Richard (ed.). Journal of art historiography, n.11, Dec. 2014; cf. também KARGE, Hendrik. Projecting the future in German art historiography of the nineteenth century: Franz Kugler, Karl Schnaase and Gottfried Semper. In: WOODFIELD, Richard (ed.). Journal of art historiography, n.9, Dec. 2013.); entre outros.
} 
a partir do fim dos anos setenta do século passado, a questão do Ornamento retorna no âmbito arquitetônico, sobretudo como "parte integrante das táticas de releitura do pós-modernismo, [...] despertando igualmente o interesse dos historiadores e dos críticos". 9 A renovada historiografia do Ornamento que gradativamente se forma, concentra-se, sobretudo a partir dos anos noventa, principalmente no recorte temporal dos séculos XIX e XX, uma vez que, na maior parte das vezes, dedica-se a rever, pelos discursos sobre o Ornamento, os paradigmas historiográficos modernos. ${ }^{10} \mathrm{O}$ Ornamento e os discursos em torno dele são tomados como fontes epistemológicas para perscrutar os fundamentos próprios do modernismo. Sob esta perspectiva crítica, antes de ser objeto de repreensão e negação pelos defensores do moderno, o tema do Ornamento é compreendido, sobretudo, como um importante "campo de batalhas" e de investigações das teorias do próprio modernismo. ${ }^{11}$

Nesse sentido, de um modo geral, observa-se na maior parte das pesquisas recentes - das duas últimas décadas - que o interesse pelo discurso de Semper sobre o Ornamento acompanha a atitude de revisão crítica do modernismo. ${ }^{12}$ Se o Ornamento constitui um dos fios principais dos discursos sobre a Arquitetura no modernismo, é fato que foi no século XIX, momento de entrada no moderno, e sobretudo a partir da obra de Gottfried Semper e de seus contemporâneos como John Ruskin e Augustus Pugin, quando o Ornamento foi

\footnotetext{
9 “... partie intégrante des tactiques de relecture du postmodernisme, [...] éveillant également l'intérêt des historiens et des critiques". PAYNE, Alina. L'ornement architectural: du language classique des temps modernes à l'aube $d u \quad X X e$ siècle. Perspective [En ligne], n.1, 2010, p.77. Disponível em http://perspective.revues.org/1220. Acesso em 5.nov.2015.

10 Id. Ibid.

11 Conforme Jörg Gleiter, "o modernismo aperfeiçoa sua orientação conceitual no Ornamento: é aí onde ocorre sua reconceitualização no campo de forças culturais em mudança. O Ornamento é onde as mentes se dividem, mas menos no sentido do gosto do que como um ponto onde as questões teóricas centrais do período se cristalizam: o Ornamento é o campo de batalhas da teoria". Tradução de: "Modernism hones its conceptual orientation on ornament: this is where its reconceptualization in the changing cultural force field occurs. Ornament is where minds divide, but less in the sense of taste than as the point where the central theoretical questions of the period crystallise: ornament is the battlefield of theory". Ornament: the battleground of theory. In: GLEITER, Jörg (ed.) Zona \#4. Ornamento. Ritorno del represso. Bolzano: Facoltà di Design e Arti dela Libera Università di Bolzano, n.8, 2009, p.14

12 Podem ser citadas as seguintes obras, cuja relação entre Ornamento e moderno, já se mostra explícita em muitos títulos: OECHSLIN, Wagner. Stilhülse und Kern: Otto Wagner, Adolf Loos und der evolutionäre Weg zur modernen Architektur. Zurich: gta Verlag, 1994; WIGLEY, Mark. White walls, designer dresses: the fashioning of modern architecture. Cambridge: MIT Press, 1995; HARATHER, Karin. Haus-Kleider. Zum Phänomen der Bekleidung in der Architektur. Wien/Koln/Wiemar: Böhlau, 1995; GLEITER, Jörg. Rückkehr des Verdrängten. Zur kritischen Theorie des Ornaments in der architektonischen Moderne. Weimar: Universitätsverlag der Bauhaus-Universität Weimar, 2002; SCHAFTER, Debra. The order of ornament, the structure of style. Theoretical foundations of modern art and architecture. Cambridge: Cambridge University Press, 2003; OCÓN FERNÁNDEZ, Maria. Ornament und Moderne. Theoriebildung und Ornamentdebatte im deutschen Architekturdiskurs (1850-1930). Berlin: Dietrich Reimer Verlag, 2004; PAYNE, Alina Alexandra. From Ornament to Object: Genealogies of Architectural Modernism. New Haven: Yale University Press, 2012.
} 
reivindicado, para posteriormente ser incriminado com Hermann Muthesius, Adolf Loos e Le Corbusier no século XX. Tem sentido pensar que, se Semper propõe uma nova conceituação e concomitante renovação dos pressupostos de utilização prática de uma categoria conceitual tradicional da Arquitetura, é porque já pressupunha sua fragilidade, mormente ao ter em conta a incipiente consagração de uma economia capitalista industrial.

Isto favorece a compreensão do posicionamento de grande parte da historiografia recente em abordar o Ornamento em Semper como parte dos discursos que levaram ao moderno. No entanto, se o caminho tomado por esta historiografia por um lado contribui para desconstruir juízos depreciativos sobre o autor e evidenciar, pela categoria conceitual do Ornamento, sua participação na formulação do pensamento moderno, por outro lado tal caminho não dá relevo à posição do teórico hamburguês em atualizar uma abordagem tradicional do Ornamento.

É acompanhando essa posição de Semper que a presente investigação de tese pretende seguir. Ao perseguir o objetivo principal, 0 de investigar 0 conceito de Ornamento no discurso teórico de Gottfried Semper, pretende-se evidenciar como o autor identifica no Ornamento uma categoria conceitual da Arquitetura, um conceito que opera em sua disciplinaridade, a qual é igualmente revisada por Semper. Pesquisar o Ornamento em Semper é, deste modo, investigar parte de sua proposta de reorganização da Arquitetura em meados do século XIX. Argumenta-se aqui que o modo como Semper procura reformular o conceito de Ornamento e, consequentemente a disciplina Arquitetura, consiste mais na atualização de noções e pressupostos da Tradição Clássica do que em uma ruptura com o passado clássico. Semper reafirma os vínculos do Ornamento com o Estilo em Arquitetura, assim como seu imprescindível propósito de evidenciar uma ordem na edificação, ordem que guarda relações com noções construtivas, de utilidade e beleza - pressupostos que são reinterpretados pelo autor, considerando a epistemologia da época.

O empenho em sustentar o que ele compreendia serem os inexoráveis liames do Ornato com a Arquitetura podem ser observados na construção de uma historização deste elemento. ${ }^{13} \mathrm{~A}$ inserção do Ornamento em um

13 O verbete Ornar vem do latim ornare, daí Ornamento (século XIV), que deriva da palavra latina Ornamentum, daí também Ornato (século XVI), derivada do latim ornatus. Deste modo, neste estudo, 
encadeamento causal, como parte de um discurso de origem das Artes, é tributária dos esforços que desde o século XVIII procuravam redefinir a Arquitetura a partir de suas causas primeiras. A estratégia adotada por Semper é a de elaboração de uma genealogia que tem como artefato originário o adorno. Trata-se de (re)estabelecer a fabricação artística como princípio da arte, no duplo sentido que este vocábulo pode ter.

A tese está estruturada em duas partes e compreende ao todo quatro capítulos. A primeira parte é composta por um único capítulo, que pretende situar o Ornamento como conceito fundamental da Arquitetura na Tradição Clássica. Apresenta um quadro sintético de noções e conceitos interdependentes que estruturaram na Tradição a ideia de Ornamento, não deixando de destacar transformações desta concepção no declínio do vitruvianismo. Esta primeira parte tem a intenção de fundamentar a argumentação da segunda, a qual trata propriamente do conceito de Ornamento em Semper e, quando possível, dos pontos de contato com a acepção tradicional.

É objetivo do capítulo 2, que inicia a segunda parte, investigar o discurso de Semper sobre a origem das Artes e nela situar o Ornamento. Analisam-se as premissas teóricas e conceituais que fundamentam este discurso das origens e as evidentes relações genealógicas que o autor estabelece entre Ornamento e as artes. Na sequência, o capítulo seguinte examina o conceito de Estilo e o papel preponderante do Ornato nele. Estilo em Semper deve ser compreendido como um atributo qualitativo de uma obra, sua excelência artística, medida pela adequada correspondência do tratamento dos fatores internos e externos da obra a uma ideia cultural da época. Nessa concepção de Estilo, que apresenta proximidades àquela da Tradição Clássica, o Ornamento caracteriza a linguagem particular da arquitetura de cada grupo cultural, consistindo, com isso, no meio pelo qual se conferem sentidos à obra. O último capítulo exemplifica esses sentidos, na medida em que investiga a caracterização simbólica que o autor confere ao Ornato arquitetônico a partir de sua particular interpretação da Ornamentação grega. Aí observa-se como, mediante uma comparação entre gregos, assírios e egípcios, Semper manifesta evidente predileção aos

Ornato e Ornamento são utilizados como sinônimos, de modo intercambiável. CUNHA, Antônio Geraldo da [et.al.]. Dicionário Etimológico Nova Fronteira da Língua Portuguesa. RJ: Editora Nova Fonteira, 1982, verbete Ornar. 
primeiros. Somente os gregos compreenderam e assimilaram a ordem do universo, ordem que associa e une exemplarmente aspectos construtivos, de utilidade e beleza, e que deveria ser perseguida na contemporaneidade.

As fontes selecionadas para a pesquisa de tese, de um modo geral, correspondem a determinado recorte temporal da trajetória de Semper. Apesar de menções ao Ornamento ocorrerem desde sua primeira publicação de juventude que trata do tema da policromia clássica, Vorläufige Bemerkungen über bemalte Architectur und Plastik bei den Alten (1834), ${ }^{14}$ uma abordagem crítica e investigativa sobre este tema só é assumida a partir de seus anos de exílio em Londres (1850-1855), momento a partir do qual ele se dedica mais à atividade teórica. ${ }^{15}$

É na capital inglesa, mediante a experiência diária da Exposição Industrial de 1851, resultado da conquista de um emprego temporário, que o teórico toma uma maior consciência crítica dos efeitos da indústria capitalista e seus métodos no campo artístico tradicional. ${ }^{16} \mathrm{~A}$ má qualidade dos artefatos da indústria fica evidenciada ao compará-los com aqueles exibidos pelas nações menos desenvolvidas - ou seja, aquelas nações que não alcançaram progresso material - e mesmo com os produtos da tradição artística ocidental. "Ao lado de tantos avanços técnicos", reconhece Semper em Wissenschaft, Industrie und Kunst - publicação em que ele apresenta suas considerações sobre a exposição -, "nós permanecemos bem atrás deles no formal, mesmo no adequado e no apropriado". ${ }^{17}$ As ideias expostas nessa obra contribuíram para sua colocação como professor das Schools of Design em Londres, ao lado de profissionais como Henry Cole, Owen Jones, Richard Regrave e Ralph Wornum. ${ }^{18}$ Todos

\footnotetext{
${ }^{14}$ Altona: Johann Friedrich Hammerich, 1834. Esta publicação é resultado de sua viagem às terras clássicas entre 1830 e 1833.

${ }^{15}$ No ano de 1849, por conta de sua insurgência contra a coroa de Dresden como parte das revoluções que ocorreram nas principais cidades europeias entre 1848-9, Semper teve que abandonar os territórios de língua alemã. Nesta época, ele atuava já há quinze anos como professor da escola de Arquitetura da Academia de Belas Artes de Dresden, primeiro cargo de ensino que ocupou. Antes de Londres, Semper procurou sem sucesso se estabelecer profissionalmente em Paris, cidade em que ele havia realizado sua formação como arquiteto.

${ }^{16} \mathrm{Na}$ exposição, Semper foi encarregado de organizar a decoração dos expositores de Canadá, Turquia, Dinamarca e Suécia, Estados de menor expressividade na exibição. HERRMANN, Wolfgang. In exile: Semper in Paris and London. In: Massachusetts: MIT Press, 1984, pp.9-83.

17 "Bei so manchen technischen Fortschritten sind wir im Formellen, ja selbst im Angemessenen und Zweckgemässen, weit hinter ihnen zurückgeblieben". Wissenschaft, Industrie und Kunst: Vorschläge zur Anregung nationalen Kunstgefühles, bei dem Schlusse der Londoner Industrie-Ausstellung. Braunschweig: Vieweg und Sohn, 1852, p.11.

${ }^{18}$ As Schools of Design foram criadas na segunda metade da década de 1830 e tinham a finalidade de reformar a educação da arte industrial britânica. A partir da Exposição de 1851, foi oferecida a Henry Cole
} 
praticamente compartilhavam o ponto de vista de que "nossos melhores objetos são reminiscências mais ou menos fiéis"19 e "a maior parte é uma confusa mistura de formas", ${ }^{20}$ como sustenta Semper. A melhora da qualidade do desenho da indústria britânica - principal objetivo das Schools - tinha como um de seus argumentos o uso indiscriminado e aleatório do ornamento nos artefatos industriais, o que gerou intensos debates e especulações entre esses profissionais. ${ }^{21}$

É a partir desse período em Londres que os textos de Semper direcionamse mais abertamente ao tema do Ornamento, assim como ao dos objetos industriais. Ainda assim, observa-se que o autor não abandonou problemáticas de investigação anteriores, como sua teoria dos quatro motivos da Arquitetura apresentada na célebre obra Die vier Elemente der Baukunst ${ }^{22}$-, sua defesa do revestimento policromo e sua concepção do Estilo. Todas estas problemáticas, após algumas mudanças e revisões, são reunidas em um discurso único na grande obra Der Stil, finalizada quando Semper já trabalhava em Zurique como professor da recém formada (1855) Eidgenössische Polytechnische Schule, atual Eidgenössische Technische Hochschule Zürich (ETH Zürich), da Universidade de Zurique.

Fazem parte desta pesquisa não somente as publicações de meados do século, mas igualmente manuscritos do autor, alguns já publicados e outros inéditos, os quais se encontram reunidos no Semperarchiv na ETH. ${ }^{23} \mathrm{O}$ contato com este arquivo possibilitou também o acesso a desenhos do teórico - alguns

a administração do Department of Practical Art das Schools. Por intermédio de Cole, a partir de 1852, Semper passa a fazer parte do corpo de professores e a ministrar aulas sobre trabalhos em metal. Em outubro de 1853, o Departament foi reorganizado sob o nome de Department of Science and Art, momento a partir do qual foi conferida a Semper a responsabilidade pelas aulas de "Construção Prática, Arquitetura e Decoração Plástica". Sobre as Schools, conferir BELL, Quentin, The Schools of Design. London: Routledge \& Kegan Paul, 1963. Sobre o período de trabalho de Semper nas Schools, conferir HERRMANN, Wolfgang. Gottfried Semper: in search of architecture. Cambridge, Massachusetts: MIT Press, 1984, p.6583.

19 "Unsere besten Sachen sind mehr oder weniger getreue Reminiscenzen...". SEMPER, Wissenschaft, Industrie und Kunst, p.11.

20 "Das meiste ist verworrenes Formengemisch...". Id.lbid., p.11.

${ }^{21}$ CHESTNOVA, Elena. 'Ornamental design is... a kind of practical science'. Theories of ornament at the London School of Design and Department of Science and Art. Journal of Art Historiography, n.11, 2014, pp.1-18. Disponível em https://arthistoriography.files.wordpress.com/2014/11/chestnova.pdf. Acesso em 20.out.2015.

22 O título completo é Die vier Elemente der Baukunst: ein Beitrag zur vergleichenden Baukunde. Braunschweig: Vieweg und Sohn, 1851.

${ }^{23}$ Os manuscritos citados nesta tese seguem a numeração do arquivo, classificada por Wolfgang Herrmann. O acesso a esta documentação foi proporcionado por bolsa CAPES para estágio de Doutorado Sanduíche na Universidade de Zurique. A duração da bolsa foi de outubro de 2015 a janeiro de 2016 e foi realizada sob a supervisão da Privatdozentin Barbara von Orelli-Messerli, do Kunsthistorisches Institut. 
dos quais estão servindo como ilustração desta tese ${ }^{24}$-, além de bibliografias recentes sobre Semper e acerca do tema do Ornamento.

Essa proximidade às bibliotecas e ao arquivo da Universidade de Zurique foi de fundamental importância para a conclusão da presente pesquisa, uma vez que investigações acadêmicas sobre Gottfried Semper ainda são escassas no Brasil, algo que acompanha a inexistência de traduções de suas obras para o português. As traduções e publicações em inglês de seus principais livros e de alguns manuscritos ${ }^{25}$ - trazidas a público no decorrer das três últimas décadas - também foram um grande auxílio para a preparação e o desenvolvimento da pesquisa, principalmente no sentido de possibilitar cotejar com os originais. ${ }^{26}$

Não obstante as carências citadas, no transcurso do desenvolvimento desta tese surgiram traduções para o espanhol que certamente contribuirão para modificar o cenário investigativo, senão no Brasil, ao menos nos demais países latino-americanos. ${ }^{27}$ Sobretudo a tradução do Der Stil irá provavelmente contribuir para modificar aquilo que, na América Latina, segundo Juan Ignacio Azpiazu, era abordado somente em círculos especializados e conhecido de segunda mão, ou seja, por outros autores. ${ }^{28}$ A presente tese pretende acompanhar este incipiente momento de divulgação científica, favorecendo assim novas pesquisas, principalmente no Brasil.

\footnotetext{
${ }^{24}$ Não é intenção do presente trabalho problematizar teoricamente as imagens. Estas são abordadadas como ilustração de ideias do autor, do mesmo modo que ele as trabalhou em suas obras.

${ }^{25}$ London lecture of November 11, 1853. In: PELLIZZI, Francesco (ed.). RES: Anthropology and Aesthetics, New York, London: Cambridge University Press, 1983, v. 6, pp.5-31; London lecture of autumn 1854: On architectural symbols. In: PELLIZZI, Francesco (ed.). RES: Anthropology and Aesthetics, New York, London: Cambridge University Press, 1985, v. 9, pp.61-67; The four elements of architecture and other writings. Trans. Harry Francis Mallgrave and Wolfgang Herrmann. Cambridge: Cambridge University Press, 1989; Style in the Technical and Tectonic Arts; or Practical Aesthetics. 2 vol. Trans. Harry Francis Mallgrave and Michael Robinson. Los Angeles: Getty Research Institute, 2004.

${ }^{26}$ Em francês não há tradução completa, em 2007 foi feita a tradução somente de trechos do Prolegômenos e do primeiro volume do Der Stil, publicados juntamente com outros textos do autor (cf. Gottfried Semper du style et de l'architecture, Écrits, 1834-1869. Trad. Jacques Soulillou et Nathalie Neumann. Marseille: Éditions Parenthèses, 2007).

${ }^{27}$ Semper: El estilo. (EI estilo em las artes técnicas y tectónicas, o, Estética práctica y textos complementários). Trad. Juan Ignacio Azpiazu. Buenos Aires: Azpiazu ediciones, 2013 e Escritos fundamentales de Gottfried Semper. El fuego y su protección. Edición y prólogo de Antonio Armesto. Trad. Manuel García Roig Barcelona: Fundación Arquia, 2014.

${ }^{28}$ AZPIAZU, Juan Ignacio. Prefacio. In: Semper: El estilo, op.cit., pp. IV-XI.
} 
I. O CONCEITO DE ORNAMENTO EM ARQUITETURA NA TRADIÇÃO 


\section{O ORNAMENTO NA TRADIÇÃO CLÁSSICA}

Falar em Ornamento na Tradição Clássica da Arquitetura é indubitavelmente remeter a questão aos dois principais protagonistas da tradição das preceptivas artísticas, do "acervo de normas, critérios e procedimentos por meio dos quais se efetua a distinção entre simples 'coisas' e as 'obras' às quais se atribui o estatuto de Arte". ${ }^{29}$ Trata-se do romano Vitrúvio ${ }^{30}$ (c.a séc. I a.C - I d.C.) e do genovês Leon Battista Alberti (1404 - 1472), cujos escritos serviram de fonte primordial para todos os sentidos e interpretações do Ornamento na tradição: Vitrúvio, com a obra De Architectura, elaborou o único tratado de Arquitetura de que se tem conhecimento ter sobrevivido do período denominado Idade Antiga, estabeleceu um conceito de Arquitetura que a define como originária não somente de uma ação sobre a matéria (fabrica), mas também de uma operação intelectual (ratiocinatio) e orientou a ciência do arquiteto como sendo "ornada de muitas disciplinas e de vários saberes". ${ }^{31}$ Alberti, por sua vez, apesar de se dedicar aos estudos dos antigos tendo como referência a orientação vitruviana, criou, a partir deste referencial, novos sentidos para as artes às quais ele pretendia afirmar o estatuto de liberais. ${ }^{32}$ Além disso, como apontado por Mário Krüger, sua escrita foi caracterizada pela "enorme versatilidade, que se manifesta tanto na variedade dos temas abordados, como nos diversos estilos de linguagem", ${ }^{33}$ e foi responsável, com sua obra $D e R e$ AEdificatoria, por abrir "as portas da modernidade em Arquitetura". ${ }^{34}$ Segundo

${ }^{29}$ AZEVEDO, Ricardo Marques de. Preceptivas artísticas. In: AZEVEDO, Ricardo Marques de; D’Agostino, Mário Henrique Simão; Loewen, Andrea Buchidid. Preceptivas Arquitetônicas. São Paulo: Annablume, 2015, p.7.

${ }^{30}$ Este de quem, segundo Mário D’Agostino, infelizmente, "desconhecemos inclusive o nome completo, apenas o gentilício Vitruvius..." Cf. D’AGOSTINO, Mário Henrique Simão. Vitrúvio, De Architectura. In: AZEVEDO, Ricardo Marques de; D’Agostino, Mário Henrique Simão; Loewen, Andrea Buchidid. Preceptivas Arquitetônicas. São Paulo: Annablume, 2015, p. 15.

31 VITRÚVIO. Tratado de Arquitetura. Tradução, introdução e notas M. Justino Maciel. SP: Martins Fontes, 2007, livro I, capítulo I, p.61. Deve-se ter em mente aqui fabrica e ratiocinatio no sentido de que a Arquitetura não se sustenta só na teoria, nem só na prática. Deste modo, a prática é fabricação, no sentido de obras feitas pela mão, que têm previamente estabelecido seu propósito, sendo fruto de uma reflexão. A teoria explica e demonstra o que é feito pela mão e é exercitada com método e solércia.

32 LOEWEN, Andrea Buchidid. Lux pulchritudinis. Sobre beleza e ornamento em Leon Battista Alberti. SP: Annablume, 2012. Consoante Loewen (Ibid., p.17), Alberti perseguiu tal empreitada "recolhendo os veneráveis saberes, sistematizando-os e adicionando suas próprias perquirições, [...] unificando e redefinindo noções para então distribuí-las com conveniência e colocá-las de maneira precisa e oportuna em meio à policromia lexical que conforma e luz sua preceptiva".

${ }^{33}$ Cf. KRÜGER, Mário. A escrita do De Re AEdificatoria de Leon Battista Alberti. In: AZEVEDO, Ricardo Marques de; D’Agostino, Mário Henrique Simão; Loewen, Andrea Buchidid. Preceptivas Arquitetônicas. São Paulo: Annablume, 2015, p.39.

34 Id.lbid., p.39. 
Harry Francis Mallgrave, "como o primeiro tratado sobre Arquitetura do Renascimento, o esforço de Alberti está ao lado do de Vitrúvio como um dos dois pilares da teoria clássica". 35

Até fins do século XVIII e princípios do XIX, ou seja, até o período que a historiografia caracteriza como crepúsculo do que se entende por Tradição Clássica em Arquitetura ${ }^{36}$, nos variados gêneros preceptivos publicados, o Ornamento é reconhecido como um elemento que possui um status central. Isto porque não somente estava estreitamente ligado ao que se entendia por beleza na Arquitetura, como também era um elemento que conferia significado a esta arte, responsável por fazê-la "falar", 37 atuando, conforme coloca Alina Payne, como "o veículo para 'explicar' a Arquitetura, para domesticar sua abstração em termos acessíveis a um observador". 38

No entanto, se, segundo também afirma Alina Payne, no Renascimento, momento em que se iniciam as preceptivas da chamada Idade ou Era Moderna - destacando-se não só o tratado arquitetônico de Alberti, mas também os primeiros ensaios de interpretação do legado vitruviano -, não houve algum tipo de teoria geral do Ornamento, tampouco definições claras, ficando as discussões centradas mais nas ordens arquitetônicas ${ }^{39}$, foi a partir do final do século XVIII que, com o questionamento da legitimidade da tradição vitruviana e com ele a aceitação do caráter opcional das ordens, se estabelecem novas problematizações sobre o Ornamento e seu papel na Arquitetura, certamente sugerindo os rumos que este elemento iria assumir ao longo do século XIX.

Neste capítulo pretende-se observar as interpretações do conceito de Ornamento na Tradição, observando, a partir de uma escrita estruturada em uma longa duração, noções e pressupostos interdependentes que deram sentido ao termo. Desta forma, esta parte se constitui em uma investigação geral das significações doadas pelas preceptivas arquitetônicas clássicas à concepção de

\footnotetext{
${ }^{35}$ Cf. MALLGRAVE, Harry Francis. Architectural Theory. Vol I: An anthology from Vitruvius to 1870. Oxford: Blackwell Publishing, 2006, p. 31. Tradução de "As the first renaissance treatise on architecture, Alberti's effort stands alongside that of Vitruvius as one of the twin pillars of classical theory".

36 Cf. AZEVEDO, Ricardo Marques de; D’Agostino, Mário Henrique Simão; Loewen, Andrea Buchidid. Preceptivas Arquitetônicas, op.cit. Conferir sobretudo páginas 7-8 e 11-13.

${ }^{37}$ AZEVEDO, Ricardo Marques. Arquitetura falante. In: MUHAN, Adma; LAUDANNA, Mayra; BAGOLIN, Luiz A. (org.) Retórica. SP: Annablume; IEB, 2012, pp.45-62.

38 "...the vehicle to "explain architecture, to domesticate its abstraction in terms accessible to a viewer...". PAYNE, From ornament to object, op.cit., p.8.

39 PAYNE, Alina. Reclining bodies: figural ornament in Renaissance architecture. In: DODDS, George; TAVENOR, Robert (ed.). Body and Building. Essays on the changing relation of body and architecture. Cambridge, London: the MIT Press, 2002, pp.95-113.
} 
Ornamento em Arquitetura e em uma análise de como isso chega em fins do século XVIII e princípios do XIX. Trata-se de um recorte deliberado no espaço e no tempo, uma vez que são analisadas algumas das principais teorizações que forneceram noções de continuidade ou ruptura ao conceito. Em outras palavras, trata-se de explorar no "tema que remete a um intento normativo que se enceta em tempos helênicos e que esteve em alta voga até meados do século XIX", 40 de um modo sintético, os efeitos de sentidos atribuídos ao Ornamento em Arquitetura.

O caminho percorrido para isto, como observado, é o de investigar doações pontuais recebidas pelo conceito durante a Tradição, como, por exemplo, suas referências na arte Retórica, sua regulação a partir do que se entende por Decoro, a relação com a beleza em uma acepção clássica e, por último, seu enquadramento no que é entendido por ordens arquitetônicas nesta Tradição. Depois disto, como será sugerido, no que diz respeito aos estudos teóricos das artes, e sobretudo da Arquitetura, com o advento da Estética, ou o incitar do "cultivo da excelência no gosto" ${ }^{41}$ e a tematização das ideias de sublime e gênio, esgotar-se-á a validade dos preceitos clássicos ${ }^{42}$ e um novo momento para o Ornamento deve ser levado em conta.

\subsection{A Retórica antiga e o Ornamentum vitruviano}

Ao se observar o sentido do termo tradição de uma maneira ampla, voltam-se os olhos para uma possível forma de continuidade ou permanência, escrita ou oral, seja de uma doutrina, de uma visão de mundo, de costumes ou de valores de determinado grupo cultural ou de determinadas escolas ou correntes de pensamento. No presente caso, fala-se em Tradição Clássica em Arquitetura, aquela continuada por meio de gêneros literários preceptivos os quais, de certa forma, podem ser identificados temporalmente considerando $o$ alcance contemporâneo das pesquisas em Arquitetura. Isto é, com começo a

\footnotetext{
${ }^{40}$ Cf. AZEVEDO, Ricardo Marques de; D’AGOSTINO, Mário Henrique Simão; LOEWEN, Andrea Buchidid. Apresentação. In: AZEVEDO, Ricardo Marques de; D’Agostino, Mário Henrique Simão; Loewen, Andrea Buchidid. Preceptivas Arquitetônicas, op.cit., p. 07.

${ }^{41}$ AZEVEDO, Ricardo Marques de. Preceptivas Artísticas. In: AZEVEDO, Ricardo Marques de; D’Agostino, Mário Henrique Simão; Loewen, Andrea Buchidid. Preceptivas Arquitetônicas, op.cit., p.11.

42 Id. Ibid. p. 13.
} 
partir da primeira tratadística arquitetônica, o escrito supérstite de Vitrúvio, e o fim aproximadamente contemporâneo aos escritos de Quatremère de Quincy (1755-1849), datados entre fins do século XVIII e as primeiras décadas do XIX. ${ }^{43}$

Contudo, deve-se atentar para uma questão chave para a compreensão do termo tradição. Quando se aborda aqui a ideia de Tradição Clássica, compreende-se tradição não como um encadeamento de transferências de elaborados técnicos relativos a um campo disciplinar específico, mas como repertório apropriado e transmitido que tem como principal meio o papel do autor, este entendido como um fiador e transmissor de um saber legimitado.

Seguindo a acepção de Leon Kossovitch, percebe-se na ideia de Tradição Clássica "[...] menos a recepção do que a doação que se considera, ênfase que lança o termo na rede dos contributos em que ressalta a autoria [...]". ${ }^{44}$ Neste sentido, Kossovitch, observando o sentido que os autores latinos atribuíram para a ideia de tradição, observa que o

autor é o instituidor do não dado e que, por isso, oferece sua contribuição para uma arte de seguidores, os quais, captados pela promessa de fama e mais bens que retornam ao aprendizado, são exortados nos proêmios de muitos tratados, a contribuir, por sua vez, para a mesma arte. ${ }^{45}$

Para ele,

na tradição como doação, o que surge como contributo torna-se repertório, mas este, como tesouro das tópicas da invenção, não se petrifica em virtude da movência dos acrescentamentos contributivos, do mesmo modo que o autor se expõe como modelo a não ser copiado, mas emulado. ${ }^{46}$

É nessa perspectiva que se situa o reconhecimento da autoridade dos autores antigos para as artes no geral, e para a Arquitetura em particular. Alguns teóricos e estudiosos da arte edificatória sustentam que no período que é denominado Idade Antiga, a ideia de Arquitetura, conforme exposta no texto do

\footnotetext{
${ }^{43}$ Para fins deste estudo, adotar-se-á esta delimitação conceitual, considerando também como marco da Idade Moderna a retomada dos preceitos clássicos com Alberti no século XV.

${ }^{44} \mathrm{O}$ autor observa que neste sentido dá continuidade a uma abordagem abrangentemente exposta por J. A. Hansen. Cf. KOSSOVITCH, Leon. Tradição Clássica. Desígnio: revista de história da arquitetura e urbanismo. / Universidade de São Paulo. Faculdade de Arquitetura e Urbanismo. Área de concentração de pós-graduação. História e fundamentos da arquitetura e urbanismo. São Paulo: Annablume, - n.5 março de 2006, p. 17.

45 Ibidem, pp. 15-16.

46 Ibidem, pp. 17-18.
} 
arquiteto romano Vitrúvio, tomou emprestado alguns preceitos e sentidos da chamada arte Retórica. ${ }^{47}$ Tal relação tem uma boa aceitação nos estudos acadêmicos atuais e acredita-se que, para observar de perto os problemas do Ornamento no contexto da Tradição Clássica, torna-se inevitável analisar esses empréstimos.

De modo geral, a Retórica pode ser compreendida pela expressão arte da palavra, ou melhor, como sugeriu Roland Barthes, a "arte da persuasão"48 pela palavra, à princípio falada, posteriormente escrita. ${ }^{49}$ Trata-se, pode-se dizer, de uma particular "arte de pensar e de comunicar o pensamento". 50 No transcurso da Tradição Clássica, caracterizava-se por ser uma téchne - um conjunto de regras, de receitas, experimentadas praticamente e passíveis de transmissão -, que pretendia uma eficaz argumentação do discurso, podendo ser o conteúdo da argumentação real ou não. ${ }^{51}$

À princípio "produto da experiência consumada de hábeis oradores"52, a codificação de preceitos mais antiga que sobreviveu da época Antiga foi a Arte Retórica, de Aristóteles (384 a.C. - 322 a.C.). Nos três livros que compõem a obra, o conteúdo é estruturado considerando-se os três gêneros reconhecidos de discurso na época, o judiciário, o deliberado e o epidítico, os quais, em tempos latinos, foram interpretados tendo em vista três finalidades do discurso: a persuasão (movere), a instrução (docere) e o deleitar (delectare), as quais orientaram a construção dos discursos durante toda a Tradição Clássica.

Mas se Aristóteles é o autor do tratado de Retórica mais antigo conhecido que sobreviveu e referenciou esta téchne, também os escritos de seus

\footnotetext{
47 Entre eles, podem-se citar, por exemplo, na França, o pesquisador Louis Callebat, e no Brasil, os pesquisadores Andrea Buchidid Loewen, Mário Henrique Simão D’Agostino e Ricardo Marques de Azevedo. Cf. CALLEBAT, Louis. Rhetorique et Architecture dans le De Architecture de Vitruve. In : GROS, Pierre. (a cura di) Le Profect de Vitruve. Object, Destinataires et Réception du De Architecture, Acte de Colloque International (Rome, 26-27/03/1993), Rome, 1994, também AZEVEDO, Ricardo Marques de; D’Agostino, Mário Henrique Simão; Loewen, Andrea Buchidid. Preceptivas Arquitetônicas, op.cit..

48 BARTHES, Roland. A retórica antiga. Tradução de Lede Pinto Mafra Fruzun. In: COHEN, Jean et. al. Pesquisas de Retórica. Rio de Janeiro: Ed. Vozes, 1975, p.148.

49 Pois a Retórica se torna um elemento pertinente ao campo da explicação das coisas por meio da linguagem textual, como por exemplo, no campo jurídico, no âmbito do Direito, já definidas as disciplinas modernas jurídicas.

50 ALEXANDRE JÚNIOR, Manuel. Prefácio. In: ARISTÓTELES. Retórica. Tradução de Manuel Alexandre Júnior, Paulo Farmhouse Alberto e Abel do Nascimento Pena. Lisboa: Imprensa Nacional - Casa da Moeda, 2005, p.10.

51 Conforme Barthes, a Retórica enquanto uma "arte" no sentido clássico da palavra seria a "arte da persuasão, conjunto de regras, de receitas, cuja realização permite convencer o ouvinte do discurso (e mais tarde, o leitor da obra), mesmo se aquilo que se pretende inculcar for 'falso'”. Cf. BARTHES, Roland. A retórica antiga. In: COHEN, Jean et al. Pesquisas de Retórica, op.cit., p.148.

${ }^{52}$ ALEXANDRE JÚNIOR, Manuel. Introdução. In: ARISTÓTELES. Retórica, op.cit., p.16.
} 
sucessores latinos da Antiguidade foram fundamentais para que os preceitos da Retórica alcançassem as preceptivas da Arquitetura das Idades Antiga e Moderna e contribuíssem na constituição do conceito de Ornamento. Marcus Fabius Quintilianus (35-40 d.C. - 96 d.C.), por exemplo, em seu Instituto Oratoria, trata da formação do orador desde sua infância, e nos doze livros que a compõe, ele trabalha com os cinco cânones da Retórica, ou seja, cinco etapas necessárias para se fazer um discurso, a saber, inventio, dispositio, elocutio, memoria e actio. ${ }^{53}$ Enquanto memoria e actio referem-se mais à exposição oral no sentido de que apontam, respectivamente, para a memorização das palavras e para o ato de proferir o discurso, as três primeiras remetem à estrutura linguística da forma retórica, pois implicam em encontrar aquilo que será dito (inventio), organizá-lo (dispositio) e colocá-lo em palavras (elocutio). ${ }^{54}$

Pode-se afirmar que o que se entendia por elocutio - o como estruturar 0 discurso eficazmente a partir dos argumentos escolhidos, da escolha do ornamento das palavras, das figuras de linguagem - foi aquilo que mais contribuiu com sentidos para importantes conceitos da Arquitetura. ${ }^{55}$ Ao referirse à composição linguística do discurso (assim como inventio e dispositio), ao modo de estruturá-lo - certamente tendo em vista seu propósito -, elocutio estava voltada para questões que envolviam o Estilo da obra, conceito caro e explorado em Arquitetura até os dias atuais e que, por um bom tempo na história e teoria da Arquitetura, manteve, pode-se dizer, uma relação de interdependência com o conceito de Ornamento.

Certamente, parte das bases do famoso texto do Instituto Oratoria é proveniente dos escritos de Marcus Tullius Cícero (106 a.C. - 43 a.C.), um dos grandes oradores da Antiguidade e que, anteriormente a Quintiliano, forneceu sua contribuição teórica para a arte da Retórica romana. ${ }^{56}$ A julgar pelas referências ciceronianas em tratados arquitetônicos, tanto da Antiguidade

\footnotetext{
53 BARTHES, A retórica antiga, op.cit.

${ }^{54}$ CHIAPPETTA, Angélica. Uma arte da memória do século XVII. In: MUHAN, Adma; LAUDANNA, Mayra; BAGOLIN, Luiz A. (org.) Retórica. SP: Annablume; IEB, 2012, pp.63-89.

55 Segundo Marta Várzeas, no período helenístico - de que é datado o texto de Vitrúvio, por exemplo -, o interesse da Retórica desloca-se, de uma ênfase anterior na inventio, centrada na descoberta dos argumentos mais adequados a cada propósito do discurso, para a elocutio, a elocução, "daí a atenção particular dada às questões relacionadas com a composição literária, com o estilo das obras modelares...". Cf. VÁRZEAS, Marta. Introdução. In: LONGINO, Dionísio. Do sublime. Trad., introdução e comentário Marta Isabel de O. Várzeas. SP: Annablume, 2015, p.14.

${ }^{56}$ BARTHES, $A$ retórica antiga, op.cit.
} 
quanto da era Moderna, ${ }^{57}$ pode-se afirmar que sua contribuição foi fundamental para que problemas e conceitos relativos à Retórica pudessem ser pensados também para a arte da edificação, como, por exemplo, os conceitos de Estilo e de Ornamento. ${ }^{58}$

Apesar de, na tradição da Retórica antiga já houvesse uma noção da existência de diferentes estilos do discurso que correspondessem a gêneros literários diferentes e a distintos propósitos discursivos, foi Cícero quem propôs a ideia de uma correspondência entre a tarefa do orador e os estilos ou genera dicendi (gêneros discursivos). ${ }^{59}$ Ou seja, para as três finalidades do discurso do orador (movere, docere, delectare) existiriam três estilos ou gêneros discursivos, que seguiam regras próprias e eram regidos por seus próprios critérios: o estilo humilde ${ }^{60}$ o médio e o elevado. Consoante Várzeas,

o humilde assentava numa linguagem simples e clara, desprovida de Ornatos, e visava o docere; o médio, também chamado florido, era o estilo elegante que tinha por fim o delectare; o elevado, sublime ou grandiloquente, caracterizavase por uma linguagem ornada, escolhida de acordo com a elevação dos assuntos tratados, e com a qual se pretendia movere. ${ }^{61}$

Para a apresentação de um discurso eficaz e convincente, o Ornamento, entendido no sentido de palavras e figuras de linguagem, era um dos importantes requerimentos, aquela qualidade especial que auxiliava na necessária persuasão do conteúdo. ${ }^{62}$ Mas não era algo que poderia ser formulado em um livro de regras, sua utilização necessitava de habilidades especiais do orador, talento e inventividade, como, por exemplo, saber escolher as palavras mais

\footnotetext{
57 Andrea Loewen e Mária Henrique S. D’agostino, por exemplo, destacam a importância das ideias de Cícero na formulação de conceitos dos tratados de Vitruvio e Alberti, como Ornamento, Decoro e Beleza. Cf. D’AGOSTINO, Mário Henrique Simão; LOEWEN, Andrea Buchidid. Retórica e Ornamento em Vitrúvio e Alberti. In: AZEVEDO, Ricardo Marques de; D'AGOSTINO, Mário Henrique Simão; LOEWEN, Andrea Buchidid, Preceptivas Arquitetônicas, op. cit., 2015, pp.89-108.

58 Segundo Barthes, Cícero ao focar na elocutio, "desintelectualiza" a retórica de Aristóteles, "quer penetrarIhe a especulação de 'gosto'”. BARTHES, A retórica antiga, op.cit., p.158.

59 VÁRZEAS, Marta, Introdução, op.cit. Estilo também pode ser designado como character segundo a autora.

60 Também assinalado como tenro ou simples.

61 VÁRZEAS, Marta, Introdução, op.cit., p.15.

62 Segundo Cícero, "há três qualidades, então, em uma simples palavra, as quais o orador pode empregar para ilustrar e adornar sua linguagem: ele pode escolher ou uma palavra incomum, ou uma que é nova ou metafórica". Tradução de: "There are three qualities, then, in a simple word, which the orator may employ to illustrate and adorn his language: he may choose either an unusual word, or one that is new or metaphorical". CICERO. De oratore; or on the character of the orator. In: CICERO. Cicero on oratory and orators. Trans. J. S. Watson. NY: Harper and Brothers, 1875, XXXVIII, p.235.
} 
adequadas à finalidade do discurso, ao tipo de audiência, e distribuí-las de modo inteligente, inovador e inesperado.

O Estilo é caracterizado não somente por essa escolha das palavras e pela atenção à sintaxe do texto, mas também pela forma da frase e pelo ritmo resultante de uma combinação harmoniosa das palavras selecionadas. ${ }^{63}$ Esta combinação harmoniosa, estando também em conformidade com a necessidade do discurso, embeleza-o, produzindo certa simetria (concinnitatis). O ornamento do discurso deve atender estes princípios:

um discurso, então, [...] para que seja significativo, agradável, para conter erudição e conhecimento liberal, ser digno de admiração, polido, ter sentimento e paixão, tanto quanto for requerido, são qualidades não limitadas a membros particulares, mas são aparentes em todo o corpo; mas que seja, por assim dizer, espargido com flores de linguagem e pensamento, é uma propriedade que não deve ser difundida igualmente por todo o discurso, mas em tais intervalos, para que, como no arranjo dos ornamentos, possa haver certos objetos notáveis e luminosos dispostos aqui e ali. ${ }^{64}$

De acordo com o propósito de cada discurso, o Ornamento atende a certa conformidade, na quantidade e no tipo. Nesse sentido, o decorar, ou seja, o "equipar" ou o "revestir" o discurso com acessórios apropriados a sua expressão, não deveria ser algo feito sem regras ou controles, mas sim atender à necessidade do discurso, seguindo com isso o princípio da adequação, do Decoro ou decor (decorum).

Trata-se de um princípio fundamental a toda tradição retórica antiga, que deve ser entendido como a forma de saber o que é apropriado para determinado momento ou ocasião. Na arte da Retórica de Cícero, consoante D’Agostino e Loewen, ele consiste em "um tipo de sabedoria para o que é apropriado na vida e na eloquência da oratória", 65 isto é, o Decoro age sobre a ideia de conveniência. O sentido ciceroniano de decor, no retor, seria que "a excelência da elocução prima pela conveniência entre o tema e o estilo, entre as ideias e as

\footnotetext{
63 Id. Ibid.

64 "A speech, then, [...] for that it be weighty, agreeable, savoring of erudition and liberal knowledge, worthy of admiration, polished, having feeling and passion in it, as far as is required, are qualities not confined to particular members, but are apparent in the whole body; but that it be, as it were, strewed with flowers of language and thought, is a property which ought not to be equally diffused throughout the whole speech, but at such intervals, that, as in the arrangement of ornaments, there may be certain remarkable and luminous objects disposed here and there". CíCERO, De Oratore..., op.cit., XXV, pp.219-220.

65 D’AGOSTINO, Mário Henrique Simão; LOEWEN, Andrea Buchidid. Retórica e Ornamento em Vitrúvio e Alberti, op.cit., p. 94.
} 
palavras, entre estas e as pessoas" ${ }^{66}$. Ter o domínio de tal habilidade significava saber escolher os ornamentos adequados para exprimir o discurso, seu tipo, sua quantidade e sua localização no texto, e isto seria expor "a concordância e harmonia das partes entre si e com o todo"67, a concinidade, ou seja, aquela combinação harmoniosa que caracteriza a beleza do discurso.

Ao observar as ideias postas por Cícero sobre Ornamento e Decoro na arte da Retórica, nota-se que as semelhanças e proximidades entre o que viria a ser Ornamento, Decoro e decoração na Arquitetura não seriam mera casualidade, apesar dos sentidos desses termos terem certamente sofrido modificações na história.

A referência a preceitos da Retórica no mais antigo tratado de Arquitetura que chegou até os dias atuais pode ser compreendida como um empenho de Vitrúvio em afirmar a Arquitetura como uma arte liberal, que seria uma arte dotada - como é sustentado já no primeiro capítulo do primeiro livro do tratado - não somente de fabricação, mas também de uma "ação intelectual de cálculo, reflexão e projetação". 68 Todavia, como sugeriu D’Agostino, há de se atentar para a crítica que Leon Kossovitch tece acerca de análises que levam em consideração a ideia de "unidade das artes", as quais partem de um paradigma criado na modernidade e que apontam para uma orientação que pode ser considerada anacrônica. ${ }^{69}$ Seguindo a sugestão de D'Agostino, tem-se como pressuposto aqui compreender tal relação apenas como "consórcios que sequer configuram um paragone propriamente dito", 70 mas que "corroboram empréstimos pontuais de termos da Retórica no De Architectura”. ${ }^{71}$

Observado isto, nota-se que está justamente nos sentidos do termo decorum um dos empréstimos estabelecidos entre os escritos ciceronianos da Retórica e o escrito de Vitrúvio sobre Arquitetura. No capítulo dois de seu livro primeiro, o arquiteto romano estabelece o decorum como uma das seis partes

\footnotetext{
66 Id.Ibid., p.95, grifo dos autores.

67 Id. Ibid. p. 96.

${ }^{68}$ AZEVEDO, Ricardo Marques de. Arquitetura falante, op.cit., p.46.

69 D’AGOSTINO, Mário Henrique S. As palavras e as pedras. In: Desígnio: revista de história da arquitetura e urbanismo. Universidade de São Paulo. Faculdade de Arquitetura e Urbanismo. Área de concentração de pós-graduação. História e fundamentos da arquitetura e urbanismo. São Paulo: Annablume, - n.5 março de 2006, pp.39-44.

70 Ibidem, p. 40.

71 Ibidem, p.40.
} 
constitutivas da Arquitetura, ${ }^{72}$ e segundo D'Agostino e Loewen, neste tratado, "o termo decor, embora raro na época de Augusto, possui significado homólogo ao ciceroniano". ${ }^{73}$ Desta forma, concluem estes autores que "as aproximações ficam patentes com a assimilatio vitruviana entre os estilos da elocução - 'tenro, médio, elevado', segundo a fórmula ciceroniana - e as 'ordens arquitetônicas' dos templos". ${ }^{74}$

Trata-se, como se pode observar em passagens do texto de Vitrúvio, de atentar principalmente para a destinação da obra e a recepção que ela deveria ter pelos destinatários. Isto é mais explicitamente exposto na célebre e muitas vezes citada passagem do livro primeiro acerca dos três gêneros de desenhos de templo e o caráter particular que cada um deveria seguir a partir do Decoro. $\mathrm{O}$ trecho orienta sobre quais estilos deveriam ser mais adequados para cada divindade e propõe que

a Minerva, Marte e Hércules, levantam-se templos dóricos; com efeito, convém que esses deuses, devido a sua força, se ergam edifícios despojados de Ornamentos. Os dedicados a Vênus, a Flora, a Prosérpina e às Ninfas das Fontes parece que deverão ter as características próprias do gênero coríntio, porque se pensa que, devido à delicadeza destas, os templos a elas levantados se revestem de uma justa conveniência, sendo mais gráceis e floridos, assim ornados de folhas e volutas. Se forem construídos templos jônicos a Juno, Diana, ao deus Líbero e a todos os deuses análogos, será considerada sua posição intermédia, porque o teor das suas características ficará convenientemente disposto entre o severo costume dos dóricos e a delicadeza dos coríntios. ${ }^{75}$

Para D’Agostino e Loewen, a ideia de Decoro em Cícero estaria equiparada ao significado de Ornato. ${ }^{76}$ Ambos os conceitos, tanto no discurso quanto na Arquitetura, guiam a atenção do orador ou do arquiteto com relação à adequação à ocasião, ao propósito e à audiência de sua mensagem. O Ornato seria o que evidenciaria esta adequação, contribuindo, com isso, para uma eficaz argumentação e persuasão.

\footnotetext{
72 A saber: a ordenação, a disposição, a euritmia, a simetria, o decoro e a distribuição. VITRÚVIO. Tratado de Arquitetura, op.cit..

73 D'AGOSTINO, Mário Henrique Simão; LOEWEN, Andrea Buchidid. Retórica e Ornamento em Vitrúvio e Alberti, op. cit., 2015, p. 95.

74 Ibidem, p.95.

75 VITRÚVIO, Tratado de Arquitetura, op.cit., livro I, capítulo II, p.77.

76 D’AGOSTINO, Mário Henrique Simão; LOEWEN, Andrea Buchidid. Retórica e Ornamento em Vitrúvio e Alberti, op. cit.
} 
D’Agostino e Loewen, desta forma, ressaltam que, assim como na prosa e na poesia, a ignorância no decorum seria a própria fonte de equívocos admitidos na vida, ${ }^{77}$ premissa que remete à gênese grega desse termo, uma vez que prépon assumia uma orientação que atuava não somente no âmbito artístico, mas também no campo da ética. Deveria orientar o homem em direção ao belo e ao bem, na medida em que "a conveniência culmina no benéfico, no verdadeiramente bom, no útil". ${ }^{78}$

No domínio da ideia de adequação vitruviana estavam também outros conceitos que eram regulados pelo pressuposto do Decoro e também componentes da edificação e aspectos construtivos - como os materiais e a própria implantação da edificação -, o que aponta para um amplo campo de atuação deste princípio. Azevedo assim sintetiza as relações entre a observância da conveniência e os sentidos enunciados pelo "discurso" arquitetônico na Tradição Clássica: ${ }^{79}$

assim como Aristóteles preceitua que, no enredo trágico, cada personagem aja sempre de acordo com suas características e circunstâncias, também a escolha da colunação, dos ornamentos, dos ouropéis, das dimensões e das proporções hão de se conformar ao caráter que cabe transmitir àquela específica edificação. É então que a Arquitetura começa a falar de tal forma que, vislumbrando-se a imagem de um templo, um observador avisado possa entrever qual o caráter da divindade a que ele é consagrado. Também as dimensões, as qualidades dos materiais empregados, a implantação do edifício no sítio e a ordenação eleita pronunciam algo. ${ }^{80}$

Também o Ornamento em Vitrúvio é apresentado em uma acepção que guarda semelhanças com seus propósitos na Retórica e, como observado, estava estreitamente associado ao Decoro. Comentadores do De Architectura têm se dedicado à exegese do que seria precisamente a acepção do termo Ornamentum (no plural ornamenta) nesta obra, como é o caso dos escritos de Pierre Gros.

\footnotetext{
77 Id lbid.

78 D’AGOSTINO, Mário Henrique Simão. A beleza e o mármore. O tratado De Architectura de Vitrúvio e o Renascimento. SP: Annablume, 2010, p.169.

79 Pode-se dizer que, ao longo da Tradição Clássica, o Decoro foi compreendido de diferentes modos e pontos de vista, assumindo nuances diversas a partir de circunstâncias e interesses particulares, como questões de gosto, valores ideológicos, sociais e políticos, entre outros, no entanto, manteve sempre a responsabilidade por aquilo que é conveniente e adequado, e por isso, dentre outros, regulando sempre a escolha e o emprego de diferentes partes e aspectos da edificação por parte do arquiteto.

${ }^{80}$ AZEVEDO, Ricardo Marques de. Arquitetura falante, op.cit., p.47.
} 
Gros nota que a semântica do termo Ornamentum em Vitrúvio aponta para o que se entende por entablamento da obra arquitetônica, ou seja, o conjunto das partes horizontais daquilo que, a partir do Renascimento, ficou conhecido como "ordem" arquitetônica. ${ }^{81}$ E como se observa no tratado antigo, este conjunto horizontal consistia, essencialmente, na reprodução de elementos que originalmente foram fabricados em madeira, premissa que leva Gros a concluir que "os ornamenta constituem a metáfora petrificada - as imagens - das peças mestras da estrutura de madeira". 82 Com isso, sustenta o autor que o Ornamentum vitruviano era de função exclusivamente portante. ${ }^{83}$

De fato, de acordo com o texto de Vitrúvio, os templos antigos constituíam obras de carpintaria que obedeciam a uma conformidade adequada a seu propósito e uma ordem construtiva, cujas disposições e características os artífices engenhosamente imitaram na construção em pedra. ${ }^{84}$ Daí a crítica à utilização de triglífos em entablamentos jônicos, ou de dentículos nas cornijas dos entablamentos dóricos, pois tais elementos não fazem parte da estrutura original de cada estilo construtivo, o que, sendo contrário à natureza e aos costumes estabelecidos, conforme se deduz da exposição do tratado romano, acaba ferindo o postulado do Decoro. 85

Essas partes da estrutura anterior em madeira não apenas apontavam para uma necessidade estrutural, como também, considerando sua transposição para a pedra, garantiam sua própria legitimidade formal, consoante coloca Gros. ${ }^{86}$ Certamente, tendo em vista que a transposição de material implica em uma dúvida da utilidade das formas - dúvida que foi levantada séculos depois por estudiosos, uma vez que a pedra implicaria outro sistema que o da madeira

\footnotetext{
81 Cf. GROS, Pierre. Ornamentum chez Vitruve : le debat sur le décor architectural à la fin de l' epoque hellénistique. In : GROS, Pierre (org.) Vitruve et la tradition des traités d'Architecture - fabrica et ratiocinatio. Nouvelle édition. Rome: Publications de l'école française de Rome, 2006, pp.389-398. Disponível http://books.openedition.org/efr/2517. Acesso em 15.nov.2015.

82 "...les ornamenta constituent la métaphore pétrifiée - les imagines - des pièces maîtresses des charpentes de bois". Ibidem, parágrafo 12.

83 Ibidem.

84 "Assim, cada coisa tem a ver com o que Ihe é próprio, seja o lugar, seja a tipologia ou a ordem. Foi a partir dessas realidades e da obra de carpintaria que os artífices imitaram, na escultura das construções de pedra e de mármore, as disposições dos templos sagrados, julgando que deveriam ser seguidas essas invenções". VITRÚVIO, Tratado de Arquitetura, op.cit., livro quarto, capítulo II, p.208.

85 "Efetivamente, se os interiores tiverem acabamentos de bom gosto, e as entradas forem modestas e sem nobreza, não terão conveniência. Do mesmo modo, se no âmbito dos epistílios dóricos se esculpirem dentículos nas cornijas ou se nas colunas pulvinadas ou nos epistílios jônicos se inscreverem tríglifos, a aparência será afetada devido à transferência das características de diferente estilo para um outro gênero de obra, uma vez que, do antecedente, foram instituídas determinadas regras de ordem arquitetônica". Id.Ibid., livro primeiro, capítulo II, p.78.

${ }^{86}$ GROS, Ornamentum chez Vitruve..., op.cit.
} 
-, o que garantiria tal legitimidade formal seria o que Gros denomina a "[...] um pouco paradoxal dialética das origens". ${ }^{87}$

Compreende-se, nestas condições que os ornamenta vitruvianos são necessários a um duplo nível: primeiro porque eles jogam um papel primordial no equilíbrio construtivo; em seguida porque eles respondem ou reenviam aos elementos fundadores dos quais eles são a transposição estilizada. Os ornamenta são em suma, para parafrasear o título da última obra de Rykwert, artifícios necessários. ${ }^{88}$

Com isso, pode-se afirmar que os Ornamenta de Vitrúvio desempenham papel similar aos Ornamentos do discurso expostos por Cícero, ou seja, são elementos retóricos. Enquanto "metáfora petrificada" são figuras de linguagem, elementos representativos que cumprem um papel em grande medida ético são elementos de certa forma exemplares - por exprimir o adequado, o justo e o conveniente, considerando as origens. Apontam também para um saber-fazer manual, fruto do engenho humano e do pensamento racional. No tratado do arquiteto romano, é a fundamentação nas origens - em que a transposição para pedra certamente implica uma ideia de "fazer lembrar" e evitar a transitoriedade das coisas -, que sustenta o sentido dos Ornamenta, os quais, nesta lógica, não são resultado de alguma criação arbitrária ou capricho.

Gros também sustenta que o Ornamentum de Vitrúvio seria um equivalente da ideia grega de Kósmos, por indicar, já na raiz do termo, a semelhança com a noção de ordem, ordinatio. ${ }^{89}$ De fato, ao investigar o verbete cosmos em sua acepção grega kó $\mu$ os, as definições apresentadas são "pôr em ordem, ordenar, repartir, distribuir [...] adornar, embelezar...", ${ }^{90}$ daí em latim a semelhança entre ornamentum, ornare, ordinare.

$\mathrm{Na}$ acepção grega, o termo apresenta um sentido amplo, remete a um universo originário do caos que foi ordenado devido à ação de um demiurgo, assim como remete ao modo perfeito, regular e permanente de funcionamento deste universo. No texto de Vitrúvio, a ideia de ordem é mais estreita,

\footnotetext{
87 "[...] la dialectique un peu paradoxale des origines". Ibid., paragrafo 13 , grifo do autor.

88 "On comprend dans ces conditions que les ornamenta vitruviens sont nécessaires à un double degré : d'abord parce qu'ils jouent un rôle primordial dans l'équilibre constructif ; ensuite parce qu'ils répondent ou renvoient aux éléments fondateurs dont ils ne sont que la transposition stylisée. Les ornamenta sont en somme, pour paraphaser le titre du dernier ouvrage de Rykwert, des artifices nécessaires". Id. Ibid., parag.13.

89 lbid.

90 PEREIRA, Isidro S.J. Dicionário Grego-Português e Português-Grego. Porto: Livraria Apostolado da

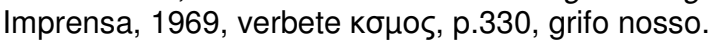


fundamenta-se, em grande medida, em uma noção ao mesmo tempo qualitativa e quantitativa de medida, nos cálculos das relações de proporção das partes da edificação entre si e com o todo - relações que têm como referência o corpo humano bem configurado pela natureza, um dos paradigmas centrais do tratado e que constituiu um dos meios pelos quais, a partir do Renascimento, os antigos eram imitados ${ }^{91}$-, e é igualmente guiada pela noção de conveniência (Decoro). ${ }^{92}$

Neste sentido, conforme o estudioso francês, os Ornamenta, enquanto as partes horizontais estruturais sobre as colunas, seriam aquilo que, por suas adequadas relações proporcionais e modulares de suas partes entre si e com as colunas abaixo, definem a função de suporte destas últimas, inclusive assinalando o próprio intercolúnio. Ou seja, consoante Gros, "eles [os ornamenta] implementam esta relação essencial entre colunas e lintéis que define justamente a noção de ordem arquitetônica". ${ }^{93}$

Apesar da exegese do termo Ornamentum em Vitrúvio apontar para tais peças horizontais estruturais da "ordem", algumas passagens do tratado abordam outras partes deste conjunto coluna e viga que são também tomadas como Ornatos, como é o caso dos elementos ornamentais da coluna jônica e da coríntia. E se o Ornamentum explicitado por Pierre Gros consiste na imitação de peças originais em madeira, os detalhes ornamentais da coluna jônica, por exemplo, sugerem uma imitação de ornamentos humanos, ${ }^{94}$ consoante expõe Clovis Lima:

não parece demasiado afirmar que no jônico as associações entre a espira e o calçado (calceo), bem como das volutas nas laterais da coluna aos cachos de cabelo, dos cimácios e festões

\footnotetext{
91 É sobretudo no livro III do tratado que estão expostas as mais importantes passagens em que o corpo masculino é base para a indicação das relações de proporção. Acerca do corpo como paradigma de imitação no Renascimento e as referências iconográficas daí resultantes, conferir TOGNON, Marcos. Arquitetura, corpo e tradição clássica: ilustrar Vitrúvio. In: Desígnio: revista de história da arquitetura e urbanismo. Universidade de São Paulo. Faculdade de Arquitetura e Urbanismo. Área de concentração de pós-graduação. História e fundamentos da arquitetura e urbanismo. São Paulo: Annablume, - n.3 março de 2005, pp.45-52.

92 Daí também a semelhança com ordinatio, uma das partes da arquitetura para o arquiteto, que trata da justa medida, das relações modulares. Conforme D'Agostino, "adstrita ao domínio da quantidade, a ordenação limita-se aos cálculos de proporção, com base em uma unidade determinada. Não se desvincula, por certo, da atenção ao destinatário[...] A ordenação mantém-se no território abstrato das relações modulares, dos tipos de composição (as species de templos, de fóruns, basílicas, etc), enfim, das doctrinae". D'AGOSTINO, A beleza e o mármore, op.cit., p.104.

93 "...qu ils mettent en oeuvre cette relation essentielle entee colonnes et linteaux qui définit justement la notion d'ordre architectural'. GROS, Ornamentum chez Vitruve, op.cit., paragrafo 15.

94 Sobre a relação do jônico com o corpo feminino, Vitrúvio sustenta que "na base colocaram uma espira imitando um sapato; no capitel, dispuseram, à direita e à esquerda, volutas, como se fossem caracóis enrolados pendentes de uma cabeleira; ornamentaram a fronte com cimácios e festões dispostos como madeixas e por todo o fuste deixaram cair estrias como drapejado das sobrevestes de uso das matronas". VITRÚVIO, Tratado de Arquitetura, op.cit., livro quarto, capítulo I, p.203.
} 
às mechas frontais, das caneluras às dobras das vestes -, constituiriam também imitações, tal como se diz que os triglífos e mútulos imitam. Mas se esses dois elementos das obras dóricas imitam o aspecto de antigas peças de madeira, os ornamentos da coluna jônica procuram transpor os ornamentos humanos (calçado, cacho de cabelo, dobras das vestes) à coluna. ${ }^{95}$

Tanto triglífos e mútulos do dórico, quanto os ornamentos supracitados do jônico ou mesmo os do coríntio, como as folhas de acanto, sugerem três caracteres diferentes - viril, feminil e virginal, respectivamente - e, juntamente com as relações de medida e tendo em vista a destinação da obra, sugerem três estilos diferentes, três distintos modos de se enunciar o discurso arquitetônico.

Outro conceito interdependente ao de Ornamento na Tradição é a noção de beleza, a qual, no terceiro capítulo do primeiro livro do tratado de Vitrúvio, é apresentada sob o termo latino venustas. No escrito vitruviano, o sentido de venustas é exposto como sendo um pré-requisito essencial da edificação, um dos princípios que o arquiteto deve ter em mente em seu trabalho. ${ }^{96}$ Consoante se observa no De Architectura, "[...] o princípio da beleza será atingido quando o aspecto da obra for agradável e elegante $e$ as medidas das partes corresponderem a uma equilibrada lógica de comensurabilidade". ${ }^{97}$ Nesta lógica estão implícitas, dentre outras, as noções correlacionadas de simetria e euritmia, ${ }^{98}$ as quais não remetem somente ao domínio de aspectos de medida

\footnotetext{
95 LIMA, Clóvis Antônio Benedini. Ratio venustatis: razões da beleza nos livros I e III do De Architectura de Vitrúvio. 2015. 222p. Dissertação (Mestrado em Arquitetura e Urbanismo apresentado para a faculdade de Arquitetura e Urbanismo da Universidade de São Paulo), São Paulo, 2015, pp.93-4.

96 Consoante Pierre Gros, o termo venustas, "construído sobre o substantivo comum Vênus, ele mesmo calcado diretamente sobre aquele da deusa do amor, implica uma relação direta com a noção de prazer". Tradução de : "...construit sur le nom commun venus, lui-même calqué directement sur celui de la déesse de l'amour, impliquait une relation directe avec la notion de plaisir'. GROS, Pierre. Voluptas chez Vitruve. In : _. Vitruve et la tradition de traités d'Architecture : fabrica et ratiocinatio. Rome : Ecole française de Rome, 2006, parágrafo 7. Venustas, neste sentido, é uma noção ligada a uma espécie de arrebatamento imediato, a um súbito ajuizamento, como se se estivesse diante do sentido do divino ; sua apreensão é, antes de mais nada, visual, do campo da apreensão pelo olhar.

97 VITRÚVIO, Tratado de Arquitetura, op.cit., livro primeiro, capítulo III, p.82.

$98 \mathrm{Na}$ acepção vitruviana, simetria seria a qualidade da obra que alcança a boa relação das partes entre si e com o todo, envolve uma idéia de perfeição métrica que engloba não somente o lado quantitativo, de estabelecimento do módulo e das relações deste com as partes, mas também o lado das medidas qualitativas ligadas ao mundo dos sentidos como cores, luz, sombra...Era uma noção do campo da doxa, de um ajuizamento comum, uma beleza apreendida quando da percepção imediata, momento em que o espectador se detém em frente à obra e é tocado por seu sentido de perfeição, por uma disposição aprazível. Importante destacar que esta noção em Vitrúvio era indissociável da noção de destinação útil da obra, de seu caráter. A euritmia seria a qualidade da obra alcançada ao se fazerem os ajustes necessários para a simetria, ajustes não somente em termos de medidas, mas também de luz, sombra, cores.... Envolve uma idéia de mensuração que aparece bela, não se restringindo, portanto, somente a números. Conferir D’AGOSTINO, A beleza e o mármore, op.cit., pp.95-101.
} 
quantitativos, como as relações de proporção métrica, ${ }^{99}$ mas também qualitativos, como, por exemplo, aqueles que envolvem o sentido de ajustes e retificações óticas, como é o caso dos triglífos, os quais, segundo Vitrúvio, antes de serem tábuas de pedra, eram tábuas em madeira pintadas e colocadas no topo das vigas transversais cortadas, "a fim de que os cortes, assim dissimulados, não ofendessem a vista". ${ }^{100}$

Entretanto, é importante observar que venustas aparece no tratado como o terceiro termo sequencial ao lado de dois outros com os quais mantém estreita relação: firmitas e utilitas, outras duas preocupações que, como depreende-se do texto, um arquiteto deveria ter em seu ofício. ${ }^{101}$ Trata-se de uma tríade conceitual, cuja ordem apresentada expõe certo vínculo de interdependência entre os três conceitos, sobretudo entre utilidade (utilitas) e beleza (venustas).

Também aí, no conúbio entre utilidade e beleza, conforme pressupõe 0 texto vitruviano, notam-se aqueles "empréstimos pontuais" da Retórica. Isto porque, assim como nos escritos de Cícero, também no de Vitrúvio a ideia de beleza, seja do discurso, seja da Arquitetura, advém da necessidade, da justa adequação ao propósito da obra, quer dizer, à finalidade do discurso do retor ou à destinação do edifício. Nota-se, nesta concepção, que novamente o Decoro é reivindicado, uma vez que, consoante D’Agostino, esta noção "se refere, sobretudo, à exposição", ${ }^{102}$ ao acolhimento pelo público, seja o que recebe o discurso do retor, seja o que observa a obra arquitetônica. Como apontam D’Agostino e Loewen, tanto nos escritos de Cícero, como nos do arquiteto Vitrúvio, "Decoro e beleza são sinônimos". ${ }^{103}$

O consórcio entre utilidade e beleza e a equiparação de seu papel na Retórica e na Arquitetura são evidenciados por D'Agostino ao mostrar que

\footnotetext{
99 Diferentemente da noção de simetria, em Vitrúvio, a noção de proporção (proportio) possui somente caráter métrico e parte do procedimento de se tomar uma parte da obra para servir como parâmetro métrico para todas as demais. Esta noção em Vitrúvio implica em um entendimento da obra a partir somente de duas dimensões, e diferencia-se da noção vigente de analogia no mundo grego, em que se tinha uma relação de três razões no mínimo, constituindo-se em altura, largura e comprimento, no caso do templo grego. Conferir D’AGOSTINO, A beleza e o mármore, op.cit., capítulo III.

100 VITRÚVIO, Tratado de Arquitetura, op.cit., livro quarto, capítulo II, p.209. Tem-se também como exemplo de retificação ótica a entasis das colunas e a solução do conflito angular do friso dórico.

101 VITRÚVIO, Tratado de Arquitetura, op.cit., livro primeiro, capítulo III.

102 D’AGOSTINO, Mário Henrique S., As palavras e as pedras, op.cit., p.42.

103 D'AGOSTINO, Mário Henrique Simão; LOEWEN, Andrea Buchidid. Retórica e Ornamento em Vitrúvio e Alberti, op.cit., p.96.
} 
"curiosamente, Cícero, quando afirma ser preciso saber não só o que dizer, mas como dizer, emprega uma imagem colhida da Arquitetura": 104

[...] as colunas sustentam os lintéis dos templos e dos pórticos, mas sua utilidade é igual a sua dignidade. Não foi, certamente, a busca da beleza, mas a necessidade que fez o célebre frontão de nosso Capitólio e de outros edifícios religiosos. De fato, uma vez cogitado o modo que permite escoar as águas de um e de outro lado do teto, a dignidade veio se unir à utilidade do frontão. ${ }^{105}$

O Decoro, ao regular o Ornamentum por suas disposições proporcionais, por sua origem lígnea, pela destinação da obra, implicava uma utilidade, como visto, e também um aspecto ético associado ao costume - o qual por sua via estava voltado a uma adequação entre o ser e o parecer, como observado na exposição de Vitrúvio. Daí a importância de todo o conjunto dos elementos de cada "ordem", tanto os detalhes decorativos quanto os estruturais, remeter a uma imagem adequada ao aspecto de solidez (firmitas) da obra - sobretudo a coluna, que endereça à imagem do homem ereto -, estando também em acordo com o caráter e a destinação da edificação. É nesta lógica de representação, daquilo que atende, enquanto representação, a um propósito, a uma destinação, que se exprime esta relação entre o útil e o belo, indicando uma concepção de que "a beleza nasce da necessidade". 106

\subsection{O Ornamentum em Alberti e a coluna como Ornamento}

Para o erudito genovês Leon Battista Alberti, autor da primeira doutrina arquitetônica do contexto da era Moderna, a Arquitetura deveria ser baseada, em seu conjunto, em três critérios fundamentais: "que os edifícios resultem adequados para suas funções"107 - e aqui Alberti está se referindo ao problema da destinação assumida na construção de determinada obra -, que "tenham a máxima solidez e duração"108, e por último, que "sejam elegantes e prazerosos

\footnotetext{
104 D'AGOSTINO, Mário Henrique S., As palavras e as pedras, op.cit., p. 42.

105 CíCERO, De Oratore, apud D'AGOSTINO, Mário Henrique S., As palavras e as pedras, op.cit., p.42. ${ }^{106}$ D'AGOSTINO, Mário Henrique S., As palavras e as pedras, op.cit., p.42.

${ }_{107}$ ALBERTI, Leon Battista. Da arte de construir. Tratado de arquitetura e urbanismo. Trad. e Org. Sérgio Romanelli. SP: Hedra, 2012, p.214.

${ }^{108}$ Id.Ibid., p.214.
} 
na forma"109. Nota-se uma referência à tríade vitruviana, e, não obstante a ordem diversa daquela exposta no tratado da Antiguidade, Alberti, guiado pela ideia de imitação do antigo - paradigma das preceptivas da era Moderna até o esmaecimento da Tradição -, assim como acreditava terem feitos seus antecessores, concedeu mais importância ao último critério, o qual, para ele, é "o mais nobre de todos, e absolutamente indispensável". 110

Trata-se, como se pode deduzir, de uma ideia de beleza, noção que Alberti se dispõe a abordar a partir do livro sexto de seu tratado, após ter dissertado sobre os outros dois até o quinto livro. Não à toa, nos cinco últimos livros do escrito, nos quais o autor se dedica ao tema do prazer que os edifícios podem suscitar, quatro deles possuem em seu título o termo Ornamento (Ornamentum). Como no tratado vitruviano, também no De Re AEdificatoria o Ornamento é um conceito intrinsecamente associado à beleza e também ao Decoro.

Tal proximidade entre beleza e Ornamento em Alberti se faz notar por uma quase equiparação conceitual sugerida pelo próprio estudioso: "o que sejam precisamente a beleza e a ornamentação, e que diferenças há entre elas, será mais fácil compreendê-lo com o espírito que expressá-lo com palavras". 111 Justifica isto afirmando ser uma opinião comum o fato de não ser de nenhum outro lugar que não fosse da "beleza e do ornamento"112 de onde nasce a impressão de prazer suscitada pela edificação:

uma prova disso poderia ser o fato de que não existe uma pessoa tão desgraçada e obtusa, tão grossa e ignorante, que não seja atraída intensamente pelas coisas mais lindas, que não prefira as mais adornadas entre todas as outras, que não fique incomodada pelas coisas feias, rejeite todas as imperfeitas ou descuidadas, e seja capaz de indicar, percebendo defeitos na ornamentação de algum elemento, o que falta para conferir elegância e decoro ao objeto. ${ }^{113}$

Nota-se, neste sentido, que, se o belo é necessário para o conceito de Arquitetura, e este está estreitamente vinculado à ornamentação, então o Ornamento, na primeira tratadística moderna, assim como em Vitrúvio,

\footnotetext{
109 Ibidem, p.214.

110 Ibidem, p.214.

111 Ibidem, p.216.

112 Ibidem, p.215.

113 Ibidem, p.215.
} 
permanece igualmente como parte essencial à obra, apesar da noção de beleza de Alberti não ser a mesma de Vitrúvio.

Andrea Loewen traz considerações que permitem compreender a distinção conceitual entre beleza e Ornamento no escrito de Alberti. Segundo a autora, a tratadística albertiana "se assenta, em grande medida, sobre uma formulação da noção de belo que distingue uma pulcritude inerente", ${ }^{114}$ concepção de beleza que é definida pelo estudioso como "a harmonia [concinidade] entre todos os membros do conjunto, conforme uma norma determinada, de forma que não seja possível acrescentar ou tirar nada sem que o todo se torne mais imperfeito". ${ }^{115}$ Nesse pressuposto da harmonia, da colocação harmônica de todas as partes do conjunto, é observável a referência na Retórica antiga, mais precisamente em Cícero e Quintiliano, em que também a escolha das partes é regida pelo princípio do Decoro. ${ }^{116}$

Consoante D’Agostino e Loewen, também é possível encontrar as referências do belo albertiano em concepções de beleza vigentes no Quattrocento. Segundo estas concepções, a Arquitetura compunha-se de dois aspectos básicos, estrutura e ornamento, podendo a beleza residir em "um dos dois ou em ambos". ${ }^{117}$ Esta antítese, revelam os autores, descortina uma diferença semântica no que diz respeito à questão: "aqueles que consideram a beleza uma qualidade intrínseca, que é percebida através do intelecto [...] e aqueles que, ao contrário, colocando mais peso na experiência sensual da beleza, consideram belo aquilo que agrada aos olhos". ${ }^{118}$ A preceptiva arquitetônica de Alberti, de certo modo, procura se posicionar tendo em conta estas duas vertentes.

Se por um lado, a beleza para Alberti é composta por pulcritude inerente, pressupondo a harmonia cósmica, por outro, é também o Ornamentum um ingrediente fundamental desta beleza. Enquanto a pulcritude consiste na instância intelectual, referente aos lineamentos da edificação, e é um "produto

\footnotetext{
114 Cf. LOEWEN, Andrea Buchidid. A beleza como Ornamento e os tratados de arquitetura do Renascimento. In: AZEVEDO, Ricardo Marques de; D’Agostino, Mário Henrique Simão; Loewen, Andrea Buchidid. Preceptivas Arquitetônicas, op.cit. p.129.

115 ALBERTI, Da arte de construir, op.cit., p.216.

116 LOEWEN, Andrea Buchidid. A beleza como Ornamento..., op.cit.

117 LOEWEN, Andrea Buchidid; D’AGOSTINO; Mário Henrique Simão. Retórica e Ornamento em Vitrúvio e Alberti,op.cit., p.90.

118 Ibidem, p.90.
} 
do ingenio"119 do arquiteto, o Ornamento albertiano equivale à matéria encarnada. ${ }^{120}$ Alberti refere-se ao Ornamentum como "uma espécie de beleza auxiliar ou de preenchimento", ${ }^{121}$ que "tem o aspecto de um atributo acessório"122 e que se acrescenta à beleza verdadeira e intrísenca dos lineamentos.

O Ornamento ainda é descrito por Alberti como "escondendo as partes que incomodavam a visão e alisando e destacando as partes mais belas", ${ }^{123}$ ou seja, a ele é atribuído o propósito de que o "desagradável resultasse menos feio e o belo mais prazeiroso", ${ }^{124}$ algo que remete à importância do Ornamento no aspecto visual da obra que já Vitrúvio tinha assinalado. Loewen, metaforicamente, equipara o Ornamento albertiano a "vestes que recobrem o corpo nu, dignificando-o, mas também corrigindo-lhe os eventuais defeitos e aprimorando suas formas". 125

Joseph Rykwert caracteriza o Ornamentum de Alberti como "a parte corpórea ou carnal da edificação", 126 o que "constitui a edificação em um fenômeno", 127 daí o fato de o erudito genovês, a partir do livro seis de seu tratado, discutir sob o termo Ornamentum uma variedade de aspectos da construção, como, por exemplo, a escolha dos materiais, a utilização das colunas, os capitéis, os revestimentos, a cobertura, a exploração de pinturas e esculturas, entre outros. Nesse sentido, lineamento e ornamentação constituem, como explicita Loewen, "momentos distintos na conformação da obra". ${ }^{28}$ Seguindo expressões exploradas por Rykwert, pode-se afirmar que o primeiro (lineamento) remete à "ideia-edifício da verdadeira beleza", enquanto o segundo (ornamentação) ao "fenômeno-edifício do ornamento", aquilo que o "veste". ${ }^{129}$

\footnotetext{
119 LOEWEN, Andrea Buchidid. Lux pulchritudinis, op.cit., p.15.

120 Consoante Loewen, o conúbio entre lineamento e matéria em Alberti reitera lição herdada do tratado vitruviano, no qual se afirma ser a Arquitetura originária da ratiocinatio e da fabrica. Quanto à importância também da instância intelectual, Rudolf Wittkower acrescenta que essa "harmonia inerente à construção [...] não provém de um capricho pessoal, mas sim do raciocínio objetivo". Tradução de "....armonía inherente a la construcción [...] no proviene de um capricho personal, sino del razonamiento objetivo". WITTKOWER, Rudolf. La arquitectura en la edad del Humanismo. Buenos Aires: Editorial Nueva Visión, 1958, p.39.

${ }^{121}$ ALBERTI, Da arte de construir, op.cit., p.216.

122 Ibidem, p.216.

123 Ibidem, p.216.

124 Ibidem, p.216.

125 LOEWEN, Andrea Buchidid. A beleza como Ornamento..., op.cit., p.129.

126 "...[ornament] is the corporeal or carnal part of the building...". RYKWERT, Joseph. Inheritance or tradition? In: RYKWERT, Joseph (ed.). Architectural Design, vol.49, n.5-6, London, 1979, p.3.

127 "... [it] constitutes the building into a phenomenon". Ibid., p.3.

128 LOEWEN, Andrea Buchidid. A beleza como Ornamento..., op.cit., p.131.

129 "idea-building of true beauty" e "phenomenon-building of ornament". RYKWERT, Joseph. Inheritance or tradition?, op.cit., p.3.
} 
Em Alberti, apesar da atribuição de novos sentidos ao conceito de Ornamento, é possível afirmar que há certa continuidade discursiva do exposto no escrito vitruviano. No tratado do estudioso de Gênova, assim como no de seu antecessor romano, percebe-se a estreita referência na Retórica antiga, por exemplo, na pressuposição de uma ordenação geral das partes do "discurso" (dispositio), ou melhor, das partes gerais da edificação enquanto ideia, e por sua colocação expositiva em "argumentos" (elocutio), em Ornamenta, os quais irão "encarnar esta ideia", evidenciando-a para os espectadores. Nesta lógica, é inegável ser o Ornamentum em Alberti algo fundamentalmente necessário à Arquitetura, pois, sem ele, como esclarece Rykwert, "nenhuma edificação pode ser usada, habitada ou mesmo vista". ${ }^{130}$ Uma vez que consiste em item importante da beleza da edificação e permanece sob a regulação do Decoro, observa-se que, também no primeiro tratado da era Moderna, utilidade e beleza evidenciam-se como princípios indissociáveis.

Sob o termo Ornamento, Alberti explora no De Re AEdificatoria uma ampla variedade de elementos, como colunas, pilastras, revestimentos, aberturas, muros, frontões, pinturas e esculturas, entre outros, que comporiam a parte material da edificação. Apesar desta diversidade, no capítulo treze do sexto livro do tratado, o estudioso destaca que "em toda a arquitetura o ornamento fundamental é constituído sem dúvida pelas colunas". ${ }^{131}$ A coluna, consoante 0 erudito, "confere beleza e decoro", ${ }^{132}$ e, assim, como fizeram os antigos, deve ser pensada para ostentar nobreza e elegância. ${ }^{133}$

A concepção albertiana da coluna como ornatus da edificação, segundo Loewen, opunha-se a uma "prática arquitetônica corrente na Florença quatrocentista, e devida, sobretudo a Brunelleschi e seus seguidores, na qual a coluna, combinada com o arco, desempenha também a função de esteio". ${ }^{134}$ Alberti mostra-se contrário ao arco sustentado por colunas, isto porque, possivelmente, como coloca Wittkower, "deve ter-se dado conta de que existia uma contradição entre a coluna redonda e o arco", ${ }^{135}$ o qual, por seu aspecto

\footnotetext{
130 "[...since without the ornament...] no building may be used, inhabited or even seen". Ibid., p.4.

131 ALBERTI, Da arte de construir, op.cit., p.244.

132 Id.lbid., p.244.

133 Ibid.

134 LOEWEN, Andrea Buchidid. A beleza como Ornamento..., op.cit., p.131.

135 "[Alberti] deve haberse dado cuenta de que existía una contradicción entre la columna redonda y el arco". WITTKOWER, La arquitectura en la edad del Humanismo, op.cit., p.41.
} 
plano, seria derivado do muro. A coluna para Alberti deveria ter um entablamento reto acima, e, em um sistema construtivo mural, estar encostada à estrutura da edificação, tendo assim seus aspectos tridimensional e plástico destacados (figuras 1 e 2), ou, transformar-se em pilastra, compatibilizando-se deste modo com a bidimensionalidade do muro.

Nessa concepção de ornatus elaborada por Alberti também se observam explícitas diferenças daquela exposta por Vitrúvio. Enquanto neste último o Ornamentum consistia nos coroamentos horizontais da "ordem arquitetônica" de efetivo propósito estrutural, no primeiro, sob a rubrica Ornamento, encontra-se uma grande amplitude de elementos materiais, "desde as pedras utilizadas nas paredes até os candelabros", ${ }^{136}$ que não assumem uma finalidade estrutural na edificação, antes, consistem em um "embelezamento do edifício no sentido mais amplo da palavra". ${ }^{137}$
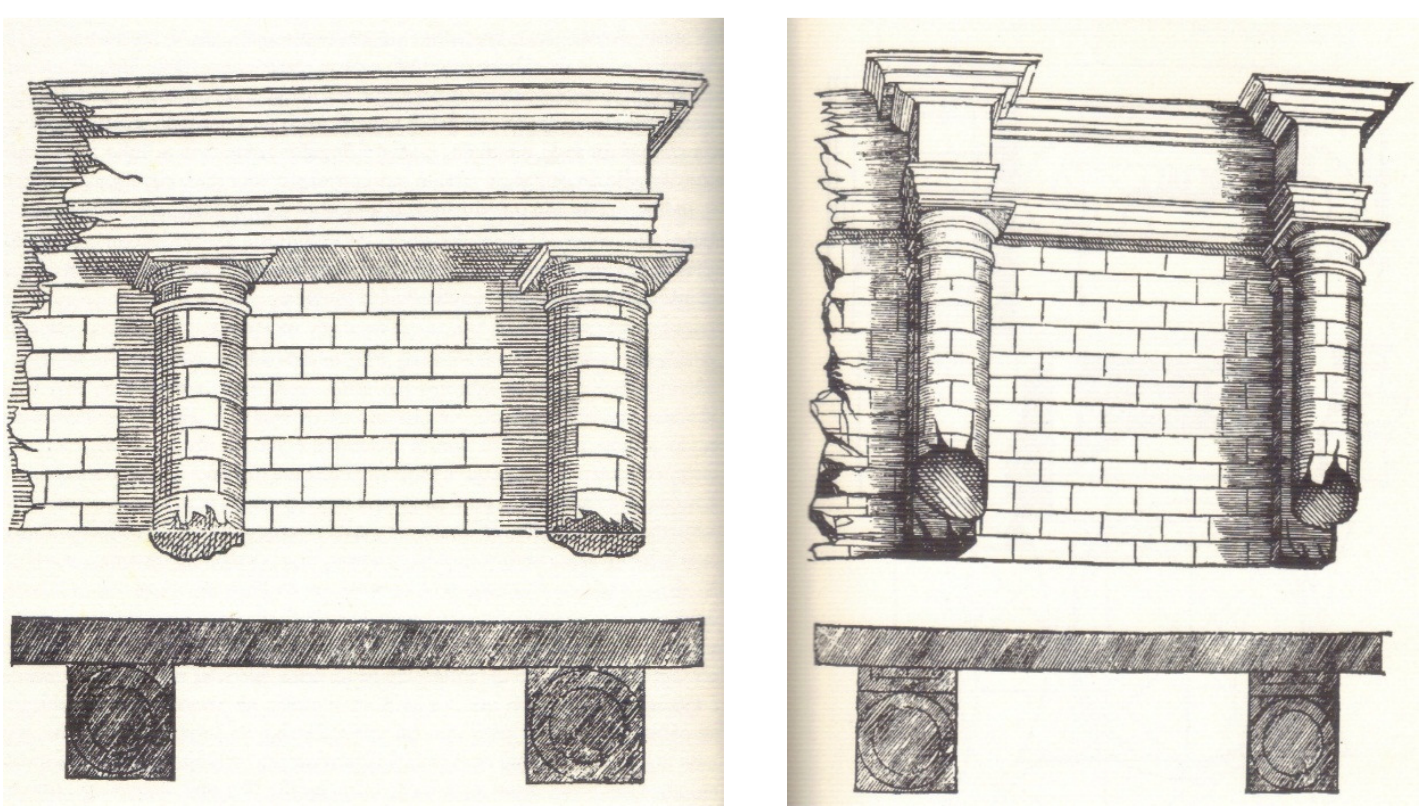

Figuras 1 e 2 - Disposição "destacada" da coluna. Desenhos da edição florentina do tratado de Alberti, de Cosimo Bartoli, do ano de 1550, publicados na edição brasileira. Fonte: ALBERTI, 2012.

Tanto a concepção de Ornamento de Alberti quanto nela o destaque da coluna como principal Ornamento do edifício foram partes importantes da fortuna crítica deste teórico tanto na teoria quanto na prática da Arquitetura da Tradição

\footnotetext{
136“...desde las piedras utilizadas en las paredes hasta los candelabros". WITTKOWER, La arquitectura en la edad del Humanismo, op.cit., p.40.

137 “...un embellecimiento del edifício en el sentido más amplio de la palavra”. Id.Ibid., p.40.
} 
que se desenrolou a partir do Renascimento. O Ornamento entendido como algo decorativo, alheio a um efetivo propósito estrutural, é observável nas leituras que os estudiosos do Renascimento e do século XVII fizeram da tradição antiga e constituía, para muitos destes, um dos meios de apropriação da Antiguidade, de imitação dos antigos. Segundo Alina Payne, iniciando-se com Alberti, ${ }^{138}$ os eruditos do Renascimento "privilegiaram a noção de uma tela ornamental aplicada que começa com pedestais, corre através de colunas e entablamentos e termina com acroteria". 139

Essa noção de tela ornamental aparece também no contexto da tradição acadêmica francesa, por exemplo, nos dicionários de Arquitetura publicados, Ornamento aparece indicado como pequenas representações, geralmente esculpidas em molduras e perfis, e caracterizadas como elementos embelezadores das edificações, que definitivamente não tinham propósito estrutural. A título de demonstração, na obra de André Félibien (1619-1695), Des principes de l'architecture, de la sculpture, de la peinture et des arts qui en dépendent, avec um dictionnaire des termes propes à chacun de ces arts, do ano de 1676, que contém o primeiro dicionário com termos de arquitetura em língua francesa, o autor, apesar de reconhecer a associação do Ornamentum de Vitrúvio às partes horizontais do entablamento, no livro sobre Arquitetura, se refere aos Ornemens como elementos não essenciais à construção, que "só servem para embelezar as partes pelas diferentes obras de escultura que aí se coloca"140, e, logo em seguida, apresenta uma prancha intitulada Des Ornemens de l'Architecture, em que estão exemplificados elementos em perfis e relevo,

\footnotetext{
138 Pierre Gros atribui a Alberti a teorização do significado, para ele (Gros), redutor que assumiu o Ornamento, ou seja, como um elemento decorativo desvinculado de um propósito estrutural. Apesar deste sentido não estrutural já vir sendo explorado na prática construtiva desde a época helenística mediante signos que remetiam a temas ou sentidos compreensíveis por quem participava daquela determinada cultura - o que explicaria parte das argumentações sobre os Ornamenta no texto de Vitrúvio - sustenta Gros, foi Alberti o responsável por constituir este sentido em uma teoria. Para Gros, a época de Vitrúvio já vivenciava um lento processo de degradação da semântica das "ordens" arquitetônicas como portadoras de significação e valor das edificações. Não sendo mais autônomas em termos de significação, eram necessários auxiliares diversos - como os ornamentos no sentido que os concebemos hoje, como no geral signos sem propósito estrutural - para transmitir a significação da obra. Gros ainda destaca que Vitrúvio teria sido um dos últimos epígonos que procurava ir contra o que seria um processo irreversível de deslocamento semântico do sentido do Ornamentum. GROS, Pierre. La notion d'ornamentum de Vitruve à Alberti, Perspective, Paris, 1, 2010, pp.130-136. Disponível em < http://perspective.revues.org/1226>. Acesso em 20.nov.2015.

139 PAYNE, Reclining bodies, op.cit., p.102. Tradução de : “...privileged the notion of an applied ornamental screen that starts with pedestals, runs through columns and entablatures, and ends with acroteria".

140 "...on peut dire qu'ils ne servent que pour embellir les parties par les differens ouvrages de Sculpture qu'on y met”. Paris: chez Jean-Baptiste Coignard, 1676, p. 37.
} 
principalmente do entablamento e da base de colunas, como guilhoches,festões, óvalos, rosetas, entre outros (figura 3)..$^{141}$

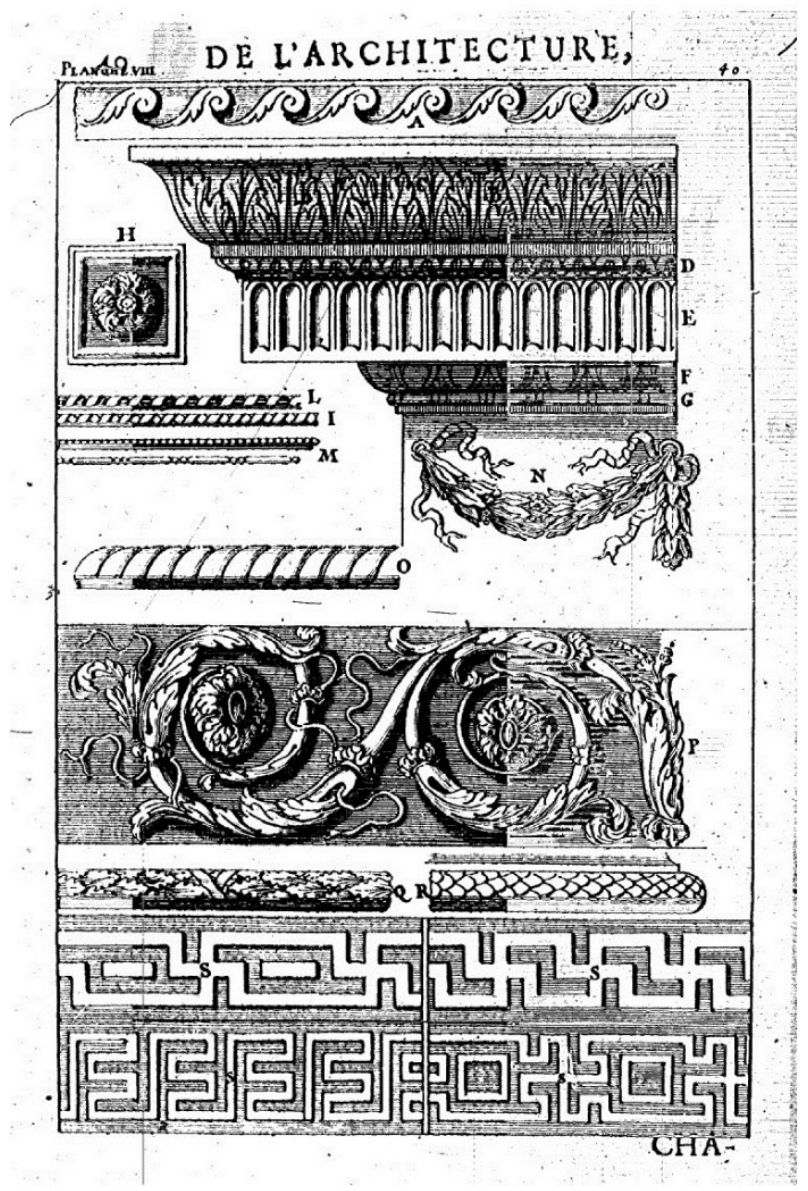

Figura 3 - Prancha "Des Ornemens de l'Architecture", do livro de André Félibien. Fonte: FÉLIBIEN, 1676.

Muito provavelmente, a principal referência às considerações de Félibien sobre o Ornamento teria sido a tradução comentada do tratado de Vitrúvio empreendida pelo arquiteto Claude Perrault (1613-1688) - quem Félibien menciona em sua obra -, que foi publicada pela primeira vez em 1673. Em seus comentários, Perrault explicita que

a palavra ornamenta em Vitrúvio significa particularmente as três partes que são colocadas sobre a coluna, a saber, a Arquitrave, o Friso e a Cornija, que é uma significação bem diferente da

\footnotetext{
${ }^{141}$ Ideia semelhante sobre o Ornamento encontra-se também na obra de Augustin Charles D'Aviler, o Cours d'Architecture...avec une ample explication par ordre alphabetique de tous les termes, de 1691 (Paris: chez Nicolas Langlois, 1691), em que ele é caracterizado como um elemento parte da decoração da obra, devendo atender ao julgamento do arquiteto e ao uso da edificação. Ainda, é possível observar no sumário que, sob a designação de ornamento, encontra-se uma grande variedade de elementos como capitéis, pedestais, colunas, lambris, cornijas, entablamentos, entre outros...
} 
significação ordinária, a qual compreende todas as coisas que não são partes essenciais, mas que são adicionadas somente para tornar a obra mais rica \& mais bela. ${ }^{142}$

O destaque dado por Alberti à coluna como principal Ornamento, conforme explicita Loewen, sugere uma "similitude entre o conceito de ornamento e o de 'ordem arquitetônica'", ${ }^{143}$ este último tão caro a boa parte da tradição da Arquitetura clássica. A não ser a definição proposta pelo estudioso genovês, o conceito de Ornamento não foi objeto de nenhuma outra definição precisa ou teorização geral em Arquitetura, ${ }^{144}$ ficando, por sua vez, estritamente associado ao conceito de ordem arquitetônica. E se a normatividade associada a esta última contribuiu para manter um padrão do emprego dos elementos ornamentais ao longo da vigência da Tradição, quando o conceito de ordem entra em questionamento e crítica, o Ornamento também é afetado.

\subsection{Ordem arquitetônica como Ornamento: normatividade e crítica}

Convencionalmente, "ordem" consiste em uma unidade formada basicamente por coluna e entablamento e que é distinguida por uma particular relação proporcional entre as partes e por um específico conjunto de elementos ornamentais. A origem do termo não é associada a Vitrúvio, tampouco a Alberti. No tratado atribuído ao primeiro, é empregado o termo "genera", do qual são reconhecidos dois, um mais severo, o dórico, e outro mais feminino, o jônico. Já no De Re AEdificatoria, Alberti se refere a "colunações" ou também a "partições", indicadas ali como dórica, jônica, coríntia e toscana. ${ }^{145}$

\footnotetext{
142 "le mot dornamenta dans Vitruve signifie particulièrement les trois parties qui sont posées sur la Colonne a savoir l'Architrave, la Frise \& la Corniche, qui est une signification bien diferente de la signification ordinaire, qui comprend toutes les choses qui ne sont point des parties essentielles, mais qui sont adjoutées seulement pour rendre l'ouvrage plus riche \& plus beau...". PERRAULT, Claude. Les dix livres d'Architecture de Vitruve corrigez et traduits nouvellement en François avec des notes et des figures. Paris: chez JeanBaptiste Coignard, (1673) 1684, p.6, n.14.

143 LOEWEN, Andrea. A beleza como Ornamento..., op.cit, p.130.

144 PAYNE, Alina. Ut poiesis architectura. Tectonics and poetics in architectural criticism circa 1570. In: KUTTNER, Ann; PAYNE, Alina; SMICK, Rebekah (ed.). Antiquity and its interpreters. Cambridge: Cambridge university press, 2000. Consoante Alina Payne, outra exceção a esta situação foi a obra do florentino Gherardo Spini, Primi tre libri sopra l'istituzioni intorno agl'ornamenti (c.1569), única obra preservada da proposta de um conjunto de cinco livros, e a qual Payne, apesar de reconhecer o isolamento do autor das principais correntes arquitetônicas da época e de seus teóricos mais importantes, observa como "uma análise densa e focada do papel e da origem do Ornamento"., p.150. Tradução de "...a dense and focused analysis of the role and derivation of ornament..."

${ }^{145}$ AZEVEDO, Ricardo Marques de. Ordens de arquitetura. In: AZEVEDO, Ricardo Marques de; D’AGOSTINO, Mário Henrique Simão; LOEWEN, Andrea Buchidid, Preceptivas Arquitetônicas, op. cit.
} 
De acordo com a historiografia, ${ }^{146}$ é no meio erudito italiano do século XVI que aparece o termo ordem, mais especificamente na Carta de RafaelCastiglione a Leão $X$ (1519). Esta consiste em um documento dedicado ao papa Leão X (1475-1521), no qual o pintor Rafael Sanzio (1483-1520), assinado como autor da carta, discorre sobre as ruínas da Roma antiga. ${ }^{147} \mathrm{O}$ termo em questão, mencionado no documento, aparece associado à arquitetura dos antigos romanos e da qual são reconhecidas cinco ordens: dórica, jônica, coríntia, toscana e ática. ${ }^{148}$

Apesar da menção de Rafael, foi Sebastiano Serlio (1475-1554), no livro IV (1537) de seu tratado,o primeiro a ser publicado e intitulado Regole generale d'architettura sopra le cinque manieri degli edificicio è Toscano, Dorico, Jonico, Corintio e Composito com gli esempi delle antichità, che per la maggior parte concordono con la dottrina di Vitrúvio, ${ }^{149}$ quem consagrou o conjunto de cinco ordens em uma sequência definida - toscana, dórica, jônica, coríntia e compósita - e mediante sua apresentação visual em gravura já no início do livro (figura 4). ${ }^{150} \mathrm{Na}$ gravura, constam não somente os ornamentos e partes que distinguem cada ordem, mas também a comensuração referente a cada uma. Neste procedimento de Serlio, observa-se que, diferentemente do proposto nos escritos de Vitrúvio e Alberti, que ao tratar de "genera", "colunações" ou "partições" referiam-se a partes ou elementos que poderiam fazer parte de um todo geral, Serlio considera a ordem como uma unidade que é subdividida em partes.

Conforme acrescenta Azevedo (Ibid., p.206), Vitrúvio também se refere em seu tratado a um "modo colunar toscano, oriundo dos etruscos" e "narra também que o escultor Calímaco, vagando pelo bosque perto de Corinto, admira sobre a lápide do jazigo de uma donzela o arbusto de acanto brotado sob uma cesta de vime coberta por uma telha e, sensibilizado, ali debuxa o capitel coríntio, que, encimando fuste e base à maneira jônica, é celebrado como conveniente para amparo e Ornamento de edifícios dedicados ao culto e ao pleito de deidades virginais".

146 Conferir, por exemplo, RYKWERT, Joseph. A coluna dançante: sobre a ordem na arquitetura. Trad. Andrea Buchidid Loewen, Maria Cristina Guimarães, Cassia Naser. São Paulo: Perspectiva, 2015 e também AZEVEDO, Ricardo Marques de. Ordens de arquitetura, op.cit.

${ }_{147}$ A Carta de Rafael-Castiglione a Leão Xé datada de cerca de 1519 e constituiu o prefácio de uma planta de levantamentos e reconstruções visuais de edificações da Roma antiga que procurava obter um registro para preservação da imagem gráfica dos monumentos da cidade antiga. Foi escrita no nome de Rafael, mas com rascunho de Baldassare Castiglione (1478-1529) e é dedicada ao papa Leão X.

148 Segundo Azevedo, a chamada "ordem ática" a que Rafael se refere, é uma remissão a Plínio e "consiste na 'ordem' que 'tem as colunas feitas de quatro lados". AZEVEDO, Ordens de arquitetura, op.cit., p.205.

149 SERLIO, Sebastiano. Regole generali di architettura sopra le cinque manieri degli edifici, cioè Toscano, Dorico, Jonico, Corintio e Composito com gli esempi delle antichità, che per la maggior parte concordono con la dottrina di Vitrúvio. Veneza, 1537.

150 "Após a publicação do primeiro dos livros arquitetônicos de Sebastiano Serlio, a formulação parece incontestável: as ordens eram cinco, e suas características aritmétricas e geométricas, assim como toda a sua decoração escultórica, estavam fixadas”. RYKWERT, A coluna dançante, op.cit., p.27. 


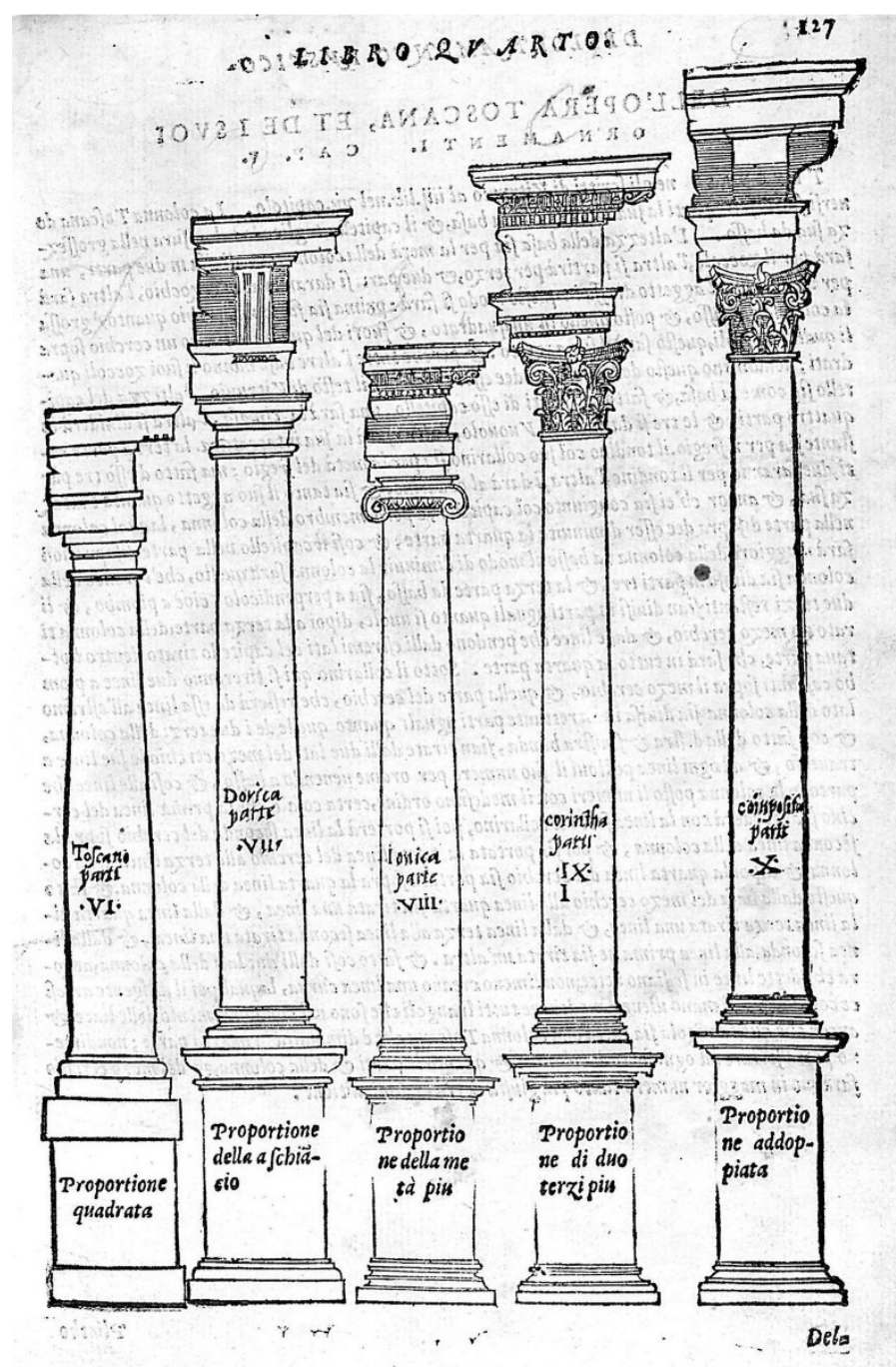

Figura 4 - Gravura das cinco ordens, de Sebastiano Serlio, publicada no livro IV da Regole Generali. Fonte: SERLIO, Regole Generali, 1537.

A Regole generale compunha um dos livros de um conjunto de sete, que, conforme o título indica, pretendia, de um modo geral, e seguindo de perto a teoria de Vitrúvio, explicitar e divulgar certa "regra geral da Arquitetura", sobre as maneiras ou modos de construir, ou seja, as "ordens", e seus respectivos ornamenti, ${ }^{151}$ no entendimento do autor. De fato, Serlio reconhece como ornamenti das cinco maneiras das edificações, "colunas, pedestais, arquitraves, frisos e cornijas, algumas portas variadas, janelas e nichos, e outros membros semelhantes..." ${ }^{152}$ os quais em suas ilustrações aparecem combinados e recombinados em diferentes arranjos compositivos para fachadas de casas de

151 SERLIO, Regole generali, op.cit., p.2.

152 lbid., p.148. Tradução de "...colonne, piedistalli, architravi, fregi, \& cornici, d'alcune porte variate, finestre, \& nicchi, \& altri simili membri separati...". 
cidade, vilas e palácios, principalmente como elementos ornamentais, seguindo o sentido da "tela ornamental" sugerida pelos escritos de Alberti.

Com o estabelecimento, no tratado de Serlio, destas cinco maneiras de edificar, as ordens, gradativamente, "passaram a ser consideradas a pedra de toque da Arquitetura [...], corporificando toda a sabedoria acumulada pela humanidade na Antiguidade no que diz respeito à arte de construir, quase que produtos da própria natureza”, ${ }^{153}$ como se assim tivesse sido na Antiguidade; o emprego das ordens, nesse sentido, constitui uma das estratégias de emulação dos antigos.

A importância disto pode ser percebida nos tratados que se seguiram, pois, conforme esclarece Azevedo, após Serlio, "a conjunção 'ordem arquitetônica' e sua enumeração quintúplice são elevadas à condição de modelo estilístico, reiteradas e pormenorizadas nos compêndios normativos sequentes". ${ }^{154}$ Também nessas publicações, como, por exemplo, o Regole delli Cinque Ordine d'Architettura, de Giacomo Barozzi da Vignola (1507-1573), as ordens são tomadas como Ornamento no sentido albertiano, como atesta Loewen. ${ }^{155}$

No estabelecimento das ordens como cânone arquitetônico, seguindo aquilo sugerido no tratado de Vitrúvio, determinados motivos ornamentais passaram a distinguir cada ordem - como as volutas a ordem jônica, os tríglifos a dórica e as folhas de acanto a ordem coríntia -, firmando a linguagem pela qual a obra exprimia seu caráter, indicando a destinação da edificação, assim como a aparência de solidez apropriada a cada uma. O repertório ornamental, de um modo geral, remetia principalmente à tradição da Antiguidade romana, ${ }^{156}$ no

\footnotetext{
153 SUMMERSON, John. A linguagem clássica da arquitetura. SP: Martins Fontes,2006, p.8.

154 AZEVEDO, Ordens de arquitetura, op.cit., p.208. Este autor ainda acrescenta (pp.208-9) que "segue-se que outros autores sancionam o acervo de ordens serliano e minuciam em seus tratados as peculiares comensurações, os elementos e os Ornamentos de cada 'ordem': entre eles sobreluzem os livros de Andrea Palladio (Palladio, 1570) e Vicenzo Scamozzi (Scamozzi, 1615), aos quais se segue copiosa messe de compêndios, digestos, tratados, manuais, précis etc., em diversos idiomas e nações até o século XIX[...] Assim, cada tratadista concebe, elabora e divulga a seleta de paradigmas que lhe parece ser a mais adequada. Embora haja evidentes variações entre as doutrinas e mensurações prescritas nos diversos tratados, as estampas transmitem a imagem, a morfologia e a regra da colenda Arquitetura 'clássica' inclusive para territórios nos quais ela não vicejara na Antiguidade, como as regiões nórdicas, o médio e o extremo Oriente e as Américas".

155 LOEWEN, A beleza como Ornamento, op.cit.

156 É importante ressaltar que, conforme coloca Irmscher, este sentido iconográfico igualmente evidencia legitimação de valores político-ideológicos. "Toda decoração, também a ornamental, é ao mesmo tempo símbolo, ou, formulado de outro modo: ela proporciona uma legitimação em níveis ideológicos. [...] A maior parte dos Ornamentos pós-medievais até o começo do século XIX, por fim, estavam direta ou indiretamente na tradição da Antiguidade romana. Desde a oligarquia financeira florentina sobre o imperador do Sacro Império Romano até a era napoleônica, cada camada dominante se compreendia ao menos idealmente
} 
entanto, não se tratava de um conjunto fixo de motivos. Consoante explicita Azevedo, a Tradição sempre esteve aberta a uma "ampla licença para o préstimo da então assaz admirada invenção (inventio), ${ }^{157}$ assim como para o emprego de elementos representativos ou simbólicos". ${ }^{158}$

A autoridade das ordens como um sistema normativo a ser seguido sobrevive, pode-se dizer, incólume, somente até o fim do século XVI e princípios do século seguinte. Apesar das variadas justificativas de sua utilização - como o fato dos antigos terem-nas usado, ou seja, sob o pretexto de uma tradição a ser mantida, ou o fato de suas proporções reproduzirem aquelas ideais encontradas no corpo humano ou no cosmos ${ }^{159}$-, a partir de meados do século XVII, especialmente no contexto da fundação da Academia de Arquitetura francesa (1671) e dos debates teóricos que dela partiram, a legitimidade das regras absolutas que elas expressavam passa a ser colocada em xeque e, com isso, sua normatividade cada vez mais a ser relativizada. ${ }^{160}$

No século XVIII, de um modo geral, é estabelecido um uso facultativo das ordens arquitetônicas, não sem intensas investidas teóricas em meio à tendência

como sucessora ou da república romana ou dos imperadores de Roma. Ornamentos antiquizantes eram, portanto, também sinais evidentes de legitimação política...". Tradução de "Jede Dekoration, also auch die ornamentale, ist zugleich Symbol, oder anders formuliert: sie vermittelt eine Legitimation auf ideologischer Ebene. [...] Die meisten nachmittelalterlichen Ornamente bis zum Anfang des 19. Jh. Letztlich direkt oder indirekt in der Tradition der römischen Antike standen. Von der florentinischen Finanzoligarchie über die Kaiser des Heiligen Römischen Reiches bis hin zur Napoleonischen Zeit begriff sich jede herrschende Schicht zumindest ideell als Nachfolger entweder der Römischen Republik oder der Imperatoren Roms. Antikisierende Ornamente waren demnach auch sinnfällige signa machtpolitischer Legitimation...". IRMSCHER, Günter. Kleine Kunstgeschichte des europäischen Ornaments seit der frühen Neuzeit (14001900). Darmstadt: Wissenschaftliche Buchgesellschaft, 1984, pp.286-287.

157 Para maior aprofundamento desta noção de licença e invenção no Renascimento, suas relações com a poética e com os escritos dos estudiosos da época, conferir PAYNE, Alina. The architectural treatise in the Italian Renaissance. Architectural invention, ornament and literary culture. Cambridge: Cambridge university press, 1999.

${ }^{158}$ AZEVEDO, Ordens de arquitetura, op.cit., p.206.

159 Conforme expõe Mallgrave, "o pensamento arquitetônico na França no começo do século dezessete, como aquele na Itália e Espanha, era baseado na noção de que a arte da arquitetura participava de uma cosmologia sancionada divinamente ou de uma ordem natural: uma gramática estável de formas eternamente válidas, números, e relações proporcionais transmitidas ao presente desde os tempos antigos". Tradução de "architectural thought in France at the start of the seventeenth century, like that in Italy and Spain, was predicated on the notion that the art of architecture participated in a divinely sanctioned cosmology or natural order: a stable grammar of eternally valid forms, numbers, and proportional relations transmitted to the present from ancient times". MALLGRAVE, Harry Francis. Modern architectural theory: a historical survey, 1673-1968. Cambridge: Cambridge university press, 2005, p.1. Para conhecimento acerca das principais justificativas apresentadas para utilização das ordens e seus autores, conferir AZEVEDO, Ordens de arquitetura, op.cit.

160 Essas dúvidas e resistências foram devidas, em grande medida, à assimilação do pensamento cartesiano em círculos científicos em meados do século na França, momento em que ocorre do mesmo modo sua recepção no meio das artes. Cf. MALLGRAVE, Harry Francis. Modern architectural theory, op.cit., p.1. Quanto aos debates teóricos resultantes em grande medida destas hesitações, vale lembrar a célebre Querelle des Anciens et des Modernes que pôs em disputa partidários de uma tradição herdada e do espírito de autoridade e partidários das ideias inéditas, por assim dizer, e do espírito de livre exame. Quanto ao teor deste debate, conferir AZEVEDO, Ricardo Marques de. Antigos modernos. Estudo das doutrinas arquitetônicas nos séculos XVII e XVIII. SP: Fauusp, 2009, pp.19-25. 
geral iluminista de crítica a conceitos consolidados e tradicionalmente aceitos e do apelo por maior racionalidade a partir da observação direta. Neste século, insurgindo contra as efusões decorativas barrocas e os abusos da ornamentação rococó e do barroco tardio, doutrinas rigoristas ${ }^{161}$ condenam a "afetação da 'arquitetura em relevo"'162, criticando, dentre outros, o uso das ordens como ornamentação. Em grande medida, é contra a tradição estabelecida a partir dos escritos de Alberti sobre o Ornamento que essas doutrinas protestam, advogando que partes construtivas portantes devam racionalmente satisfazer a seu propósito e a sua lógica racional.

Uma destas doutrinas foi a elaborada pelo abade francês Marc-Antoine Laugier (1713-1769), quem, em meados do século, reagindo às extravagâncias e arbitrariedades formais e decorativas do rococó vigentes na época, em seu Essai sur L'Architecture, publicado pela primeira vez no ano de $1753,{ }^{163}$ elabora uma noção conceitual de uma cabana primitiva que deveria servir de modelo arquetípico a ser seguido, com vistas a desvincular a Arquitetura de todo fundamento arbitrário. ${ }^{164}$ Nesta proposta de Laugier, estava implícita a crença tradicional, herdada da exegese vitruviana, de que o templo grego em pedra teria derivado sua morfologia e relações métricas diretamente de um primeiro abrigo em madeira, ou seja, o abade reconhecia o princípio da imitação em matéria lígnea descrito no tratado de Vitrúvio. ${ }^{165}$

Em uma narrativa sobre o "homem primitivo" em seu ambiente natural e confrontado com a necessidade de construção de um abrigo, ${ }^{166} \mathrm{o}$ abade relacionou a edificação a uma motivação instintiva e racional, associando as formas construtivas estritamente a propósitos estruturais, deduzidos de uma

\footnotetext{
161 Para maior aprofundamento acerca destas doutrinas e dos debates que elas levantam, conferir AZEVEDO, Ricardo Marques de. As doutrinas rigoristas do século XVIII. In: AZEVEDO, Ricardo Marques de; D’Agostino, Mário Henrique Simão; Loewen, Andrea Buchidid. Preceptivas Arquitetônicas, op.cit., pp.275-295.

162 AZEVEDO, As doutrinas rigoristas do século XVIII, op.cit., p.275, aspas do autor.

${ }^{163}$ A obra teve uma segunda edição dois anos depois (1755), desta vez acompanhada por ilustrações.

${ }^{164}$ LAUGIER, Marc-Antoine. Essai sur l'architecture. Paris: chez Duchesne, 1755.

${ }^{165}$ A ideia estabelecida por Vitrúvio de que a partir de um primeiro abrigo rústico teriam se desenvolvido construções mais elaboradas em madeira e posteriormente teria surgido o templo dórico em pedra continuou sendo reconhecida até o século XVIII, mas é Laugier quem estabelece uma relação direta da arquitetura e seus princípios deste processo transformativo.

166 Consoante Rykwert, o "homem primitivo" de Laugier era deduzido a partir da especulação, era uma noção conceitual, diferente do "homem primitivo" investigado pela arqueologia e pela antropologia na época de Semper, como se esclarecerá em seguida. RYKWERT, Joseph. A casa de Adão no paraíso: a ideia da cabana primitiva na história da arquitetura. Trad. Ana Gabriela G. de Lima, Anat Falbel, Margarida Goldsztajn e Mário Henrique S. D’Agostino. São Paulo: Perspectiva, 2003.
} 
razão natural. ${ }^{167}$ Além disso, identificou a forma final deste abrigo com aquilo que ele entendia como os elementos essenciais da composição da Arquitetura, a partir dos quais, os gregos, mediante reflexão e transcendendo as necessidades ordinárias, alcançaram perfeição no modelo do templo períptero: colunas, entablamento e frontão. ${ }^{168}$

Essas partes apontadas como essenciais, por serem partes portantes da edificação, não poderiam, no raciocínio de Laugier, ser utilizadas como ornamentação, ou seja, como elementos em relevo nas superfícies. ${ }^{169}$ Para o abade, nestas partes essenciais se encontra a beleza da obra, e elas distinguemse daquelas necessárias, introduzidas devido à inevitabilidade de um uso e que constituíam por isso licenças toleráveis como, por exemplo, a vedação dos muros entre as colunas. Se as partes necessárias são toleráveis em virtude daquilo que o uso requer, inaceitáveis eram aquelas indicadas por ele como caprichosas, a saber, aquelas partes construtivas que tradicionalmente foram utilizadas como ornamentação, como arcos, pedestais, áticos, frontões curvos ou interrompidos, nichos, entre outros. Seu fundamento era a arbitrariedade, por isto, eram a razão de todos os defeitos ou falhas na obra. ${ }^{170}$

Se a coluna era parte essencial da Arquitetura, de modo algum ela poderia ser observada e tratada como Ornamento, arrazoa o abade. O mesmo ocorria com a pilastra. Se esta havia sido pensada por Alberti como uma solução do conflito entre muro e coluna adossada, Laugier, apesar de considerá-la uma substituição inadequada da coluna - pois "a natureza não faz nada quadrado"171 -, igualmente argumentava por seu emprego estrutural:

\footnotetext{
167 Segundo Azevedo, "nas doutrinas iluministas, é premissa que o natural deva ser, por si, racional. Desse modo, a Norma da Natureza se pauta pela faculdade do Entendimento...". AZEVEDO, Ordens de arquitetura, op.cit., p.215. Conferir também do mesmo autor, Antigos modernos, op.cit. Sobre as relações entre arte e natureza no século XVIII, Ernst Cassirer esclarece que "a natureza, em todas as suas manifestações, é submetida a certos princípios que o conhecimento tem por tarefa essencial determinar e enunciar em termos claros e precisos; a arte, rival da natureza, não pode deixar de ser afetada pela mesma obrigação. A natureza está submetida a leis universais e invioláveis; devem existir para a 'imitação da arte' leis da mesma espécie e de igual dignidade". CASSIRER, Ernst. A filosofia do lluminismo. Trad. Álvaro Cabral. Campinas: Editora da Unicamp, 1992, p.373.

${ }^{168}$ Ainda de acordo com Azevedo, "... à medida que mais se retroage à pureza incorrupta das origens, mais se acerca do verdadeiro, do natural. A construção originária em rústica madeira - mais tarde perenizada em polido mármore e ajustada ao cânone da medida humana -, fixa, imutável, a forma (eidós) pela qual se consubstancia o arquétipo imaculado da verdadeira Arquitetura". AZEVEDO, Antigos modernos, op.cit., p.53.

${ }^{169}$ LAUGIER, Essai sur l'architecture, op.cit.

170 "Nas partes essenciais consistem todas as belezas; nas partes introduzidas por necessidade consistem todas as licenças; nas partes agregadas por capricho consistem todas as falhas". Tradução de : "C'est dans les parties essentielles que consistent toutes les beauté ; dans les parties introduites par besoin consistent toutes les licences ; dans les parties ajoutées par caprice consistent tous les défauts". Ibid., p.10.

171"[La Colonne doit être ronde], parce que la nature ne fait rien de quarré". Ibid., p.13.
} 
eu estou surpreso que um arquiteto coloque a pilastra no nível dos simples Ornamentos. Esta decisão é bem pouco refletida. Ele ignora que o que é chamado Ornamento é um adorno acidental de que se pode fazer uso e que se pode suprimir sem que o essencial da ordem arquitetônica sofra. Caneluras e outros embelezamentos com os quais o cinzel do escultor cobre as várias partes são Ornamentos verdadeiros porque eles podem ser aceitos ou suprimidos sem mudar a essência da coisa. ${ }^{172}$

Dentre esses "adornos acidentais", ou seja, dentre os verdadeiros ornamentos, ele reconhece os motivos ornamentais das molduras e aqueles em relevo associados ao entablamento e ao capitel de cada ordem arquitetônica, conforme o conjunto estabelecido na gravura das cinco ordens de Serlio. ${ }^{173}$ Defendendo a observância do padrão da Tradição e o cuidado com o Decoro, afirmava que esses motivos ornamentais não poderiam ser substituídos sem alterar o caráter de cada ordem. ${ }^{174}$

No entanto, apesar desta atenção ao que havia sido adotado pela Tradição, Laugier não dedica atenção às proporções em sua obra, as quais parecem não assumir para ele muita importância na questão do caráter de cada edificação. Não se trata de uma negação, ele apenas se limita a sugerir a consulta de outros autores para tratar do assunto, ${ }^{175}$ atitude que sugere não ser a questão das proporções uma parte essencial de seu pensamento teórico sobre a Arquitetura. $O$ argumento utilizado pelo estudioso para esta não atenção é de que "seu propósito [de Laugier] é somente observar o que pode interessar o gosto"176 em se tratando de cada uma das ordens.

\footnotetext{
${ }^{172}$ lbid., p.XVI. Tradução de: "J'admire qu'un Architecte mette le pilastre au rang des simples ornemens. Cette décision est bien peu réfléchie. Ignore-t-il que ce qu'on nomme un ornement, est une parure accidentelle dont on peu faire usage, et que l'on peut retrancher, sans que l'essentiel de l'Ordre d'Architecture en souffre. Les canelures et les autres richesses dont le ciseau du sculpteur charge les membres divers, sont de vrai ornemens, parce qu'on peut les admettre ou les supprimer sans altérer le fonds de la chose".

${ }^{173}$ Laugier reconhece três principais ordens, dórica, jônica e conríntia, e afirma que a toscana e a compósita são derivações destas: “...me parece que nós propriamente somente temos três ordens de arquitetura, a dórica, a jônica e a conríntia. Elas são as únicas onde se nota a invenção e um caráter especial; enquanto que a toscana e a compósita são emprestadas e só se diferenciam das precedentes de uma maneira bastante acidental". Tradução de "... il me semble que nous n'avons proprement que trois Ordres d'Architecture, le Dorique, I' lonique \& le Corinthien. Ils sont les seuls où l'ont remarque de l'invention, \& un caractere spécial; tandis que le Toscan \& le Composite n'ont rien que d'emprunté, \& ne différent des précédens que d'une maniere três-accidentelle". Ibid., p.62.

${ }^{174}$ Ibid.

${ }^{175}$ A saber, Jean-Louis de Cordemoy (Nouveau traité de toute l'Architecture) e Claude Perrault (Les dix livres d'Architecture de Vitruve...).

176 “...mon dessein étant d'observer seulement ce qui peut intéresser le gout dans chacun d'eux." Ibid., p.77, colchetes nossos.
} 
Essa pouca atenção às proporções encontra um contraponto no seu destaque ao papel do gosto. Tanto uma como o outro evidenciam o decurso de um processo de flexibilização das regras universalmente válidas e 0 deslocamento de critérios objetivos para aqueles subjetivos de apreciação e julgamento das obras que se processava no século XVIII. ${ }^{177}$ Esta mudança, que evidencia certa "antecipação da passagem de um paradigma de imitação para o da criação"178, é notada também no incentivo do abade à criação de novas ordens arquitetônicas, ou mesmo à criação de uma ordem compósita a partir das já existentes. ${ }^{179}$

Consoante coloca Schütte, no campo teórico da Arquitetura de meados dos setecentos, boa parte dos escritos passa a reclamar uma "liberdade de invenção", 180 que passa a valer sobretudo "para todos campos da arquitetura que não são determinados pelos propósitos arquitetônicos primários”. ${ }^{181} \mathrm{Se}$, de acordo com a lógica da razão moderna, as partes portantes deveriam ser coerentes a seu propósito, resta à decoração da obra, e nesta, aos elementos ornamentais, ou seja, aos pequenos ornamentos das molduras e perfis, dar curso à imaginação. ${ }^{182}$ Mas em Laugier, essa inventividade não se dava sem atenção às regras usuais das ordens - ou seja, àquilo que é essencial e característico de cada uma ${ }^{183}$-, e ao bom gosto, que pedia certo comedimento no uso do ornamento, como, por exemplo, que os ornamentos escultóricos

\footnotetext{
177 De acordo com Ernst Cassirer, o julgamento do gosto, conforme compreendido nos oitocentos, "não pretende, com efeito, tratar da 'coisa em si' e de sua natureza absoluta; enuncia tão-somente uma relação que subsiste entre os objetos e nós próprios, sujeitos perceptivos, sensíveis e judicantes". CASSIRER, $A$ filosofia do lluminismo, op.cit., pp.404-5.

178 Marco Aurélio Werle faz esta apreciação ao referir-se à obra de Charles Batteux, As Belas-Artes reduzidas a um mesmo princípio [Les beaux-arts réduits à un même príncipe], publicada alguns anos antes da de Laugier. Werle afirma ter sido esta uma característica da estética de todo o século XVIII. WERLE, Marco Aurélio. Apresentação. In: BATTEUX, Charles. As Belas-Artes reduzidas a um mesmo princípio. Trad. Natalia Maruyama e Adriano Ribeiro. SP: Imprensa oficial do estado, 2009.

179 LAUGIER, Essai sur l'architecture, op.cit.

180 "Freyheit der Erfindung". SCHÜTTE, Ulrich. Ordnung und Verzierung. Untersuchungen zur deutschsprachigen Architekturtheorie des 18. Jahrhunderts. Braunschweig/Wiesbaden: Friedrich Vieweg \& Sohn, 1986, p.153.

181 “...jene Bereichen der Baukunst, die nicht von der primär architektonischen Zwecken bestimmt sind...". lbid., p.153.

182 Id. Ibid. Schütte coloca que este apelo à liberdade criativa é observado no destaque da época, sobretudo do final do século XVIII, não somente às ordens compósitas, mas também aos arabescos, grotescos e à rocalha, cujos fundamentos estavam mais na fantasia do artista do que na natureza ou nos princípios de proporção e composição tradicionais.

${ }^{183}$ Consoante Laugier (op.cit., p.99), "seria desejável que nossos artistas olhassem mais adiante, que, pela combinação de membros que são particulares a todas as ordens, eles nos fornecessem novos capitéis, novas arquitraves, novas cornijas; é um vasto campo aberto ao gênio e à emulação". Tradução de "Il seroit à souhaiter que nos Artistes portassent plus loin leurs vûes, \& que par la combinaison des membres qui sont particuliers à tous les Ordres, ils nous donnassent de nouveaux chapiteaux, de nouvelles architraves, de nouvelles corniches; c'est un vaste champ ouvert au génie \& à l'émulation".
} 
devessem ser em baixo relevo, sem distorções das formas e em molduras sem grandes projeções. ${ }^{184}$

Outros discursos dos setecentos apontados como rigoristas foram os dos venezianos Francesco Algarotti (1712-1764) e Andrea Memmo (1729-1793), ambos discípulos e compiladores da doutrina arquitetônica do carmelita veneziano Carlo Lodoli (1690-1761) e que, assim como Laugier, seguiam o tom iluminista de critica a conceitos consolidados e que não seguissem a observação direta. ${ }^{185}$

A postura Lodoli, do mesmo modo que a do abade francês, consoante expõe Rykwert, "ignorou ou condenou as práticas correntes consideradas corruptas"186 e propôs como solução "o recurso aos princípios primeiros". ${ }^{187}$ Lodoli também ia de encontro à adoção da ordem arquitetônica e de outros elementos construtivos como ornamentação em relevo. Como Laugier, preceito fundamental em seu pensamento teórico era a coerência estrutural na construção arquitetônica, no sentido de que partes portantes deveriam ser portadoras das cargas, ao invés de suportadas.

Seguindo esse raciocínio, Algarotti, em seu Saggio sopra l'Architettura, ${ }^{188}$ critica abusos observados tanto na arquitetura antiga como na moderna, como, por exemplo, "a fachada de um templo subdividida em duas ordens e que dentro seja de uma só ordem"189 ou a utilização de cornija no interior das edificações ou em qualquer lugar coberto, pois "o próprio ofício da cornija sendo o jogar a água longe da construção"190 não é atendido neste caso. Afirmando ter a verdade como propósito, Algarotti sustenta que "em uma construção não se veja nada que não tenha seu próprio ofício e que não seja parte integrante da construção mesma". 191

\footnotetext{
${ }^{184}$ LAUGIER, Essai sur l'architecture, op.cit. Contrariamente ao que se observava nos arabescos e nas bizarrices rococó da época, que Laugier condenava.

${ }^{185}$ Acerca das aproximações e diferenças entre os escritos de Algarotti e Memmo e suas posições em relação à doutrina do mestre, conferir UNGUREANU, Cosmin. Sia funzion la rappresentazione. Carlo Lodoli and the crisis of architecture. RIHA Journal, n.18, 21 march 2011, pp.1-25.

${ }^{186}$ RYKWERT, A casa de Adão no paraíso, op.cit., p.47.

187 Ibidem, p.47

188 ALGAROTTI, Francesco. Saggio sopra l'Architettura. Veneza: Stamperia Graziosi, 1784. A primeira edição é datada de 1753.

189 "...la facciata di um tempio, che dentro sia di un ordine solo, compartita in due ordine". Ibidem, p.9.

190 “....proprio ufizio della cornice essendo il gettar lontane dalla fabbrica le acque...". Ibidem, pp.9-10.

191 "....niente ha da vedersi in una fabbrica, che non abbia il proprio suo ufizio, e non sia parte integrante della fabbrica stessa...". Ibidem, p.9.
} 
Consoante esclarece Rykwert, essas eram premissas do mestre Lodoli, para quem as partes da edificação devem ser o resultado da necessidade, a qual é prescrita pela razão. ${ }^{192}$ É esta razão analítica que deve evidenciar os princípios verdadeiros aos quais a autoridade dos antigos deveria se submeter. O aforismo de Lodoli evocado por Rykwert, "a verdade é mais antiga que os antigos", ${ }^{193}$ põe em evidencia, ainda que não explicitamente, um duplo questionamento do que foi aceito e assumido na Tradição até então: de um lado, algo que Laugier também critica, a exploração de partes portantes como suportadas, e de outro e aqui se encontra o desencontro entre Lodoli e Laugier - a suposta origem da arquitetura pétrea em uma construção em madeira.

A contraposição de Lodoli à proposição vitruviana da transposição de uma estrutura original em matéria lígnea para uma em pedra, colocava em questão o discurso tradicional das origens da Arquitetura, que na segunda metade do século XVIII assumiria a forma de controversos debates. ${ }^{194}$ Diversamente de Laugier, a razão de Lodoli, seguindo o apontamento de Rykwert, considerava "as leis da estrutura em função dos materiais". ${ }^{195}$

Andrea Memmo, na sua compilação dos escritos lodolianos, Elementi dell'Architettura lodoliana ossia l'arte del fabricare com solidità scientifica e com eleganza non capricciosa, discorre sobre as contradições das ordens arquitetônicas da tradição vitruviana, sobre a relação inapropriada entre forma clássica e pedra e condena toda parte construtiva que não surja da natureza e do propósito do material. ${ }^{196}$ A crítica de Lodoli e dos lodolianos à arquitetura antiga e moderna tem como fundamento essa desatenção da relação entre os

\footnotetext{
192 “...Lodoli não era um utilitarista. A necessidade não era imposta pela utilidade, ela era ditada pela razão...". RYKWERT, $A$ casa de Adão no paraíso, op.cit., p.56.

193 "O aforismo preferido de Lodoli afirmava que a verdade era ais antiga que os antigos e mais antiga do que os povos orientais ou gregos, ou seus pórticos ou cabanas". Ibid., p.55.

${ }_{194}$ Consoante explicita Rykwert ( $A$ casa de Adão no paraíso, op.cit., p.49), a divergência entre Laugier e Lodoli localizava-se sobretudo na questão da origem da arquitetura, questão que assumiria grande importância nas últimas décadas do século XVIII (momento em que ambos já haviam morrido), devido ao "incipiente nacionalismo do período": "Frente aos recém descobertos protótipos gregos [...], certos italianos advogaram a originalidade etrusca e sua independência com respeito aos gregos. A essa originalidade poderia ser atribuída, ainda, uma ancestralidade imemorável que remontava à primeira arquitetura em pedra dos egípcios [...] e assim, poder-se-ia considerá-la como derivando diretamente das mesmas fontes da arquitetura grega. Os romanos, como herdeiros diretos dos etruscos, convertiam-se, portanto, nos mediadores da principal corrente da arquitetura tradicional, da qual a arquitetura grega era um mero afluente".

195 Ibidem, p.56.

${ }^{196}$ MEMMO, Andrea. Elementi dell'Architettura lodoliana ossia l'arte del fabricare com solidità scientifica e com eleganza non capricciosa. Roma:Stamperia Pagliarini, 1786.
} 
elementos construtivos e a natureza e propriedade dos materiais. Acerca disto, critica Algarotti:

por que razão a pedra não representa a pedra, a madeira a madeira, cada matéria a mesma e não outra? Tudo exatamente ao contrário do que se pratica e se ensina como deve ser a Arquitetura, o que se convém às qualidades características, à maleabilidade ou rigidez das partes componentes, a níveis de força de resistência, à própria essência de uma palavra, ou natureza da matéria que é posta em obra. ${ }^{197}$

A defesa da coerência entre forma e leis estruturais, assim como forma e propriedades da matéria, pretendia antes buscar a regeneração de uma Arquitetura invadida pelas efusões e caprichos ornamentais barrocos do que banir o Ornamento do domínio da construção arquitetônica, como assevera Azevedo: ${ }^{198}$

assim, segrega-se o ornamento 'necessário' para a consignação do devido 'caráter' à obra e para a garantia da precípua variedade exigida para o encanto, a elegância e a graça do edifício do adorno considerado 'inútil', o qual, assoberbando a edificação, obnubila sua legibilidade e tolda a apreensão nítida da articulação dos elementos colocados em composição. ${ }^{199}$

Apesar do Ornamento, consoante sustenta Rykwert, sobreviver em Lodoli por questões de gosto e costume ${ }^{200}$ - razões de sua aceitação também em Laugier -, consubstanciando ainda o consórcio entre beleza e utilidade, ${ }^{201}$ a sobriedade no seu emprego é "condição para a honestidade" da obra, ${ }^{202}$ premissa ética que se observa na teorização lodoliana. Tal sobriedade, somada

\footnotetext{
197“ Perché ragione la pietra non rappresenta ella la pietra, il legno il legno, ogni materia se medesima, e non altra ? Tutto al contrario per appunto di quanto si pratica e s'insegna, tale esser dovrebbe l'Architettura, quale si conviene alle qualità caratteristische, alla pieghevolezza o rigidità delle parti componenti, a gradi di forza resistente, alla propria essenza in una parola, o natura della materia che vien posta in opera". Algarotti, Saggio sopra l'Architettura, op.cit., pp.14-15.

198 Algo que, como se sabe, ocorreria mais tarde, no funcionalismo do século XX, sobretudo a partir das investidas de Adolf Loos contra o ornamento.

199 AZEVEDO, As doutrinas rigoristas do século XVIII, op.cit., pp.284-5.

200 "O ornamento era [em Lodoli] uma questão de gosto e costume (l'uso fa legge, como havia afirmado Piranesi em seu Dialogue) ". RYKWERT, A casa de Adão no paraíso, op.cit., p.56.

201 Conforme Algarotti (Saggio sopra l'Architettura, op.cit., p.10), "não há local onde se encontra beleza em que não haja qualquer utilidade". Tradução de "che punto si trovasse di belleza là dove non si riscontri una qualche utilità".

202 Consoante Ungureanu, “.... tendência a refrear o papel do ornamento tornou-se em Lodoli uma condição de honestidade...". Tradução de "...the tendency to restrain the role of ornament [...] was turned by Lodoli into a condition of truthfulness...". UNGUREANU, Sia funzion la rappresentazione, op.cit., p.20, parágrafo 36.
} 
ao emprego de princípios objetivos, contribui para evidenciar a "verdade arquitetônica". 203

As teorias rigoristas, não obstante o reconhecimento de um ornamento necessário - que dignifica a obra na atenção à conveniência - trouxeram, de acordo com Ungureanu, "uma disjunção entre teoria e prática e a perda do conteúdo metafórico"204 da Arquitetura, este último tão essencial ao que era compreendido por Ornamento na Tradição. A valorização de uma verdade demonstrável cientificamente passa a ter precedência às "metáforas petrificadas"205 da teoria vitruviana, ou seja, aos recursos linguísticos explorados em toda a Tradição Clássica, dos quais o Ornamento era um dos itens fundamentais.

Nas primeiras décadas do século XIX, as lições de Jean-Nicolas-Durand na École Polytechnique francesa, compiladas em seu Précis des leçons d'architecture donnés à L'École Polytechnique, ${ }^{206}$ confirmam a emergência de nova ordem de valores associados à Arquitetura em que é possível notar certa depreciação semântica do Ornamento. Durand defende que os princípios mais importantes da Arquitetura seriam a economia e a utilidade e reprova não só a ideia da cabana - conforme atestada teoricamente por Laugier - e do corpo humano como referências para a imitação, mas também critica a de ordem como essência da Arquitetura, condenando sua correlata decoração como uma despesa insensata na construção arquitetônica. ${ }^{207} \mathrm{O}$ autor do Précis, ao elaborar

\footnotetext{
203 Id.Ibid., p.16, parág.30. Ungureanu sustenta que "Carlo Lodoli é talvez o primeiro a se dirigir à questão da 'verdade arquitetônica'. [...] Sua busca por verdade tem uma dimensão moral: ela aborda a ética da arquitetura tanto quanto envolve princípios construtivos objetivos". Tradução de "Carlo Lodoli is perhaps the first to address the question of 'architectural truth'. [...] His quest for truth has a moral dimension: it touches upon the ethics of architecture just as much as it engages objective building principes".

204 Certamente, seguindo o exposto por Ungureanu (lbid., p.16, parág. 29), essa mudança não se deve somente aos rigoristas; seus discursos fazem parte de um amplo fenômeno de revolução científica que vinha se processando já desde o século XVII: "seu discurso revolucionário era, na verdade, parte de um fenômeno bem mais amplo que incluía os séculos 17 e 18, e foi descrito como a crise da modernidade. Para a ars aedificatoria, isto trouxe [...] a disjunção entre teoria e prática e a perda do conteúdo metafórico na esteira da revolução científica...". Tradução de "His revolutionary discourse was, in fact, part of a much larger phenomenon that covered the $17 \mathrm{~h}$ and $18^{\text {th }}$ centuries, and was described as the crisis of modernity. For the ars aedificatoria this brought, [...] the disjunction between theory and practice and the loss of metaphorical content in the wake of the scientific revolution...".

205 Conferir nota 82.

206 DURAND, Jean-Nicholas-Louis. Précis des leçons d'architecture donnés à L'École Polytechnique. Paris : chez l'auteur, à l'École Polytechnique, 1802, Premier volume.

${ }^{207} \mathrm{Em}$ seu Précis (Ibid., p.13), Durand afirma que "se a cabana não é um objeto natural, se o corpo humano não pôde servir de modelo à arquitetura, se,na suposição mesmo do contrário, as ordens não representam a imitação nem de um e nem do outro: deve-se necessariamente concluir que estas ordens não constituem a essência da arquitetura; que o prazer que se espera de seu emprego e da decoração que delas resulta é nulo; que esta decoração, ela mesma é uma quimera; e a despesa que ela origina, uma insensatez". Tradução de "...si la cabane n'est point un objet naturel; si le corps humain n'a pu servir de modèle à l'architecture; si, dans la supposition même du contraire, les ordres ne sont point une imitation de l'un et de
} 
um sistema de desenho arquitetônico planificado a partir da planta baixa, desconsiderava a importância tradicional do volume escultórico ornamentado; daí sua crítica às ordens e à decoração.

Também sintomático de uma depreciação semântica do Ornamento e sinal de uma época já mergulhada na nova sensibilidade que advém da Estética $^{208}$ é o exposto na preceptiva arquitetônica de Quatremère de Quincy, consolidada derradeiramente na última versão de seu Dictionnaire historique d'architecture, em 1832, a qual, no verbete Decoração, caracteriza os Ornamentos arquitetônicos como "signos mais ou menos arbitrários"209, como parte de uma "reunião de objetos, de assuntos, de composições onde o gosto e o gênio do artista sabe introduzir o prazer e a aprovação naquilo que era obra da imprescindibilidade e da necessidade". ${ }^{210}$

Já conceitualmente desvinculado das ordens como unidade e conjunto decorativo onde estavam implicadas e entre si relacionadas noções de solidez, utilidade e beleza, a ideia de Ornamento que passa a se consolidar a partir dos oitocentos valora-o, em grande medida e de um modo geral, como elemento meramente embelezador, ou seja, um acessório decorativo - porque apenas atenderia a uma atração agradável do olhar.

Paradoxalmente, o século que mais explora e exalta a ornamentação a partir dos avanços técnicos obtidos com a indústria moderna e mediante a

l'autre: il faut nécessairement en conclure que ces ordres ne forment point l'essence de l'architecture; le plaisir que l'ont attend de leur emploi et de la décoration qui en résulte est nul; cette décoration, elle-même, une chimère; et la dépense dans laquelle elle entraîne, une folie".

208 Nas reflexões da Estética elaboradas a partir do século XVIII, a Arquitetura foi de certo modo ranqueada como estando abaixo das outras artes, tomada por muitos como uma arte utilitária, por ser dependente de necessidades mecânicas e materiais. Com isso, para muitos estudiosos, a Arquitetura só se caracterizaria uma arte elevada quando investida de formas mais nobres de representação artística, como, por exemplo, a ornamentação pintada e esculpida. Nesse sentido, ao transcender os processos mecânicos e as necessidades utilitárias, os ornamentos seriam os responsáveis por, na edificação, proporcionar prazer estético - um dos pilares da concepção estética da arte. Conferir, por exemplo, o escrito de MORITZ, Karl Philipp. Versuch einer Vereinigung aller schönen Künste und Wissenschaften unter dem Begriff in sich selbst Vollendeten. In: Berlinische Monatsschrift, vol.5, 1785, pp.225-30.

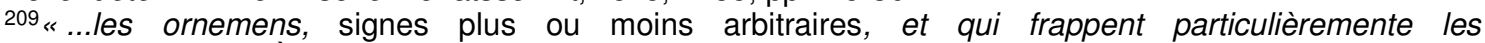
yeux...".QUATREMĖRE DE QUINCY, Antoine-Chrysostôme. Dictionnaire historique d'architecture, comprenant dans son plan les notions historiques, descriptives, archaeologiques, biographiques, théoriques, didactiques et practiques de cet art. Paris: Librairie d'Adrien Le Clère et Cie, 1832, Première Tome, p.502.

210 O trecho completo assim diz "Em um ou outro sentido, aplica se esta palavra a arquitetura, seja que se fale da arte que abrange todas as partes e todos os gêneros de Ornamento que contem o exterior e 0 interior das edificações, seja que se especifique de uma maneira particular a reunião de objetos, de assuntos, de composições onde o gosto e o gênio do artista sabe introduzir o prazer e a aprovação naquilo que era obra da necessidade".Tradução de "Dans l'un et l'autre sens, on applique ce mot à l'architecture, soit qu'on parle de l'art qui embrasse toutes les parties et tous les genres d'ornement que comportent l'extérieur et l'intérieur des édifices, soit que l'on spécifie d'une manière particulière l'emsemble d'objets, de sujets, de compositions dont le goût ou le génie de l'artiste sait introduire le plaisir et l'agrément dans ce qui n'étoit que l'oeuvre du bésoin et de la nécessité". Ibid., p. 500, grifos nossos. 
proposição restaurativa de formas nostálgicas provenientes de tempos e lugares distantes é igualmente aquele em que tal elemento passa a estar na berlinda dos debates teóricos em virtude de seus sentidos, modos de expressão e fabricação. No discurso do arquiteto e teórico Gottfried Semper, o Ornamento, se não é o tema principal, certamente é um dos alvos principais para se refletir sobre a própria ideia de Arquitetura. 
II. O ORNAMENTO SEMPERIANO 


\section{O ORNAMENTO NA ORIGEM DAS ARTES}

Por volta de meados do século XIX, não são poucos os indícios que apontam para uma crise do estatuto tradicional do Ornamento, ${ }^{211}$ perceptível primeiramente na Grã-Bretanha e com certa evolução, no decorrer do século, em outros países, conforme o processo de industrialização. São assuntos recorrentes da historiografia da Arquitetura que trata sobre este período os debates acerca da má qualidade dos objetos industriais, bem como as cópias das linguagens arquitetônicas do passado; ${ }^{212}$ situações nas quais o Ornamento está diretamente envolvido. ${ }^{213}$

Não é o caso aqui de problematizar as razões efetivas desse cenário, mas pode-se afirmar que ele foi marcado, de um lado, pelo enfraquecimento da legitimidade da Tradição Clássica em Arquitetura - algo que Luciano Patetta caracteriza como "crise do vitruvianismo"214 -, e por outro, pelo desenvolvimento, a nível ocidental, de uma sociedade capitalista industrial que trouxe modificações nos modos de se fazer e pensar parte do campo que era tradicionalmente compreendido como artístico.

Se anteriormente os objetos e elementos de decoração eram fabricados em oficinas ou ateliês tradicionais para atender a uma clientela mais restrita e definida, a partir de então seu lugar é a fábrica com seu moderno sistema de fabricação, e seu destino é, antes de tudo, o mercado. Ou seja, são destinados a consumidores indistintos e anônimos, além de fabricados semelhantemente, em grandes quantidades e muitas vezes com materiais mais baratos do que os tradicionalmente usados. ${ }^{215}$

\footnotetext{
211 Conforme coloca Jörg Gleiter, tem-se uma crise do Ornamento toda vez que sua questão é posta em debate, indicando, simultaneamente, "uma mudança estrutural fundamental que é, portanto, vista como uma crise e grande reviravolta na cultura". Tradução de "...a fundamental structural change which is therefore seen as a crisis and major upheaval in culture". GLEITER, Ornament: the battleground of theory, op.cit., p.14.

212 Conferir, por exemplo, BENEVOLO, Leonardo. História da arquitetura moderna. SP: Ed. Perspectiva, 1998, sobretudo os itens $A$ crise do ecletismo e O movimento pela reforma das artes aplicadas.

213 Apesar de já desde princípios do século os problemas relativos aos artefatos da indústria terem sido constatados em muitas localidades, como na Inglaterra e na França, o despertar para esta situação só ocorreu, em grande medida, em meados do século, principalmente com o panorama global proporcionado pela Exposição Industrial de 1851.

214 Segundo Patetta, esta crise vinha se processando desde meados do século XVIII. PATETTA, Luciano. Los revivals en arquitectura. In: ARGAN, Giulio Carlo et al. El pasado en el presente: el revival en las artes plásticas, la arquitectura, el cine y el teatro. Barcelona: Ed. Gustavo Gili, 1977, p.130.

215 Pode-se dizer que a indústria moderna altera o próprio fundamento artístico destes elementos: podem ser citados, seu valor, de certo modo, precioso, na medida em que eram fabricados manualmente (indicativo não somente do gesto de quem o fez, mas também de sua reflexão), também o valor simbólico dos materiais
} 
Para atender a esse mercado consumidor, são os Ornamentos do passado que são convocados para decorar os objetos da indústria, como uma tentativa, pode-se dizer, de conferir um status artístico àquilo que passa a ser fabricado industrialmente. ${ }^{216}$ No entanto, diversamente de boa parte do que era fabricado na Tradição, os motivos históricos são utilizados muitas vezes em locais inapropriados, com uma desatenção à escala e ao propósito do artefato. ${ }^{217}$ Alguns estudiosos da época, dentre eles o arquiteto e teórico britânico Richard Redgrave (1804-1888), observam que uma das razões principais dessa má qualidade da ornamentação localiza-se no próprio método industrial de divisão das tarefas, responsável pela dissociação entre a mente que concebe e a mão que fabrica. Redgrave declara que

- Ornamento das eras passadas era principalmente descendente do trabalho manual, o da era presente é do motor e da máquina. Esta grande diferença no modo de produção causa uma diferença similar nos resultados. Nos tempos antigos o artista era de uma vez desenhista, ornamentista e artífice e para ele era indiferente usar o lápis ou o pincel, o martelo, o cinzel ou um furador: sua mão e sua mente forjavam juntas, não somente no desenho, mas em cada estágio de sua finalização, e então entrava uma porção desta mente em cada minuto, e em cada estágio de finalização e uma bela reflexão tardia era incorporada pelas mãos do artista astuto, uma graça adicionada à obra por sua maestria e habilidade. ${ }^{218}$

\footnotetext{
genuínos (como madeira e cerâmica, por exemplo, que, se não passam a ser copiadas são substituídas por materiais menos custosos), assim como seu valor de utilidade, no sentido de que possuíam uma destinação definida e inscrita socialmente.

216 Peter Collins, ao referir-se à tendência da era vitoriana em tudo ornamentar, acredita que isso se deve a uma apreciação comum na época de ver no ornamento um símbolo de status social, algo que era particularmente observado na classe burguesa. Segundo ele, "a classe média enriquecida, mas sem o gosto refinado por uma educação aristocrática, quis imitar os poderosos de outros tempos. Não admirava a simplicidade dos móveis antigos ou dos trabalhos de talheres. Desejava reproduções de obras em rico metal, densamente trabalhado, e tapetes e tapeçaria como as dos príncipes do Renascimento". Tradução de: "...la clase media enriquecida, pero sin el gusto refinado por una educación aristocrática, quiso imitar los poderosos de otros tiempos. No admiraba la simplicidad de los muebles antiguos o de los trabajos de platería. Deseaba reproducciones de obras en metal rica, densamente trabajado, y tapices y tapicerías como las de los príncipes del Renacimiento". COLLINS, Peter. Los ideales de la arquitectura moderna; su evolución (1750-1900). Barcelona: Ed. Gustavo Gili, 1977, p.123-4.

217 É uma marca do século XIX, conforme esclarece Argan, a dissociação entre valor artístico e valor estético das obras, observada em produtos industriais de beleza duvidosa (que ele aponta com kitsch) na medida em que os processos da indústria sacrificam "manifesta e conscientemente, o fator qualitativo em benefício do quantitativo". ARGAN, Giulio. Lo artístico y lo estético. Madrid: Casimiro Libros, 2010, p.13. Tradução de "...manifiesta y conscientemente, el factor cualitativo en beneficio del cuantitativo".

218 REDGRAVE, Richard. Supplementary report on design. In: EXHIBITION OF THE WORKS OF INDUSTRY OF ALL NATIONS. Reports by the juries on the subjects in the thirty classes into which the exhibition was divided. London: William Clowes and Sons, 1852, p.710. Tradução de "The ornament of past ages was chiefly the offspring of handicraft labour, that of the present age is of the engine and the machine. This great difference in the mode of production causes a like difference in the results. In old times the artist was at once designer, ornamentist, and craftsman, and to him was indifferent to use of the pencil or the brush, of the hammer, the chisel, or the punch: his hand and his mind wrought together, not only in the design, but in every stage of its completion, and thus there entered a portion of that mind into every minute,
} 
No entanto, paradoxalmente, apesar desse reconhecimento da conjuntura social em curso, ${ }^{219}$ uma atitude comum a muitos comentadores é reforçada pelo discurso de Redgrave: a de "culpar" o Ornamento por boa parte dos males da época, levando, com isso, a uma desqualificação de seu conceito. Assim declara o estudioso:

ornamento é então necessariamente limitado, já que, assim definido, não pode ser outro que não secundário, e não deve usurpar um lugar principal; se ele o faz, o objeto não é mais uma obra ornamentada, mas é degradada a mero ornamento. ${ }^{220}$

Naturalmente, essa definição assume maior sentido se inserida no contexto de fabricação dos objetos industriais britânicos de meados do século XIX, particularmente aqueles contemporâneos à exposição industrial de 1851, ${ }^{221}$ com a qual Redgrave diretamente se envolveu; ainda assim, de fato era uma avaliação recorrente tomar o Ornamento como algo supérfluo ou acessório, provedor somente de "belas aparências" e, com isso, distante de qualquer senso de utilidade. 222

and into every stage of finish, and many a beautiful after-thought was embodied by the hand of the "cunning artificer", many a grace added to the work by his mastery and skill".

219 Reconhecimento que revela, de certo modo, um olhar um tanto quanto nostálgico em relação à ornamentação dos tempos passados. O discurso de Redgrave, assim como o de outros contemporâneos, como John Ruskin (1819-1900) e Augustus Welby Pugin (1812-1852), parece impregnado por ideias românticas relativas ao modo de fabricação tradicional. No mesmo texto, ele afirma, por exemplo, que o artífice do passado "trabalhava geralmente a partir de sentimentos de piedade, a partir do amor a seus trabalhos". Tradução de "... [the old ornamentist] worked generally from feelings of piety, from love of his labours....". Ibidem, p.710.

220 "[...] Ornament is thus necessarily limited, for, so defined, it cannot be other than secondary, and must not usurp a principal place; if it do so, the object is no longer a work ornamented, but is degraded into a mere ornament". Ibidem, p.708.

${ }^{221}$ A crítica ao ornamento que usurpava visualmente as características estruturais da obra foi recorrente no século XIX. Sobretudo na Inglaterra vitoriana, ocorria um predomínio abusivo da linha curva e exuberante. Consoante Nikolaus Pevsner, "uma substituição universal da linha reta pela curva é uma das características principais do desenho de meados da era vitoriana. Contrariamente a outros estilos que favorecem a curva, a curva vitoriana é generosa, cheia ou, como foi dito mais de uma vez antes, saliente. Ela representa, e apelou para, uma classe próspera, bem satisfeita e autoconfiante. [...] Outra marca de 1850 é igualmente notável. Deve haver decoração em baixo ou alto relevo por todas as superfícies disponíveis. Isto obviamente aumenta o efeito de riqueza". Tradução de "a universal replacement of the straight line by the curve is one of the chief characteristics of mid-Victorian design. As against other styles favouring curves, the Victorian curve is generous, full or, as has been said more than once before, bulgy. It represents, and appealed to, a prospering, well-fed, self-confident class. [...] Another hallmark of 1850 is equally telling. There must be decoration in the flat or thick relief all over all available surfaces. This obviously enhances the effect of wealth". PEVSNER, Nikolaus. High Victorian design. In:

victorian and after. New Jersey: Princeton University, 1982, p.54.

222 Para os colegas de Redgrave, Ralph Wornum (1812-1877) e Owen Jones (1809-1874), o ornamento é, respectivamente, "[ornamento é] essencialmente a província do olho; são belas aparências o que nós exigimos..." e "[ornamento é mais propriamente] somente um acessório à arquitetura...". Tradução de: "[ornament is] essentially the province of the eye; it is beautiful appearances that we require..." e "[ornament is most properly] only an accessory to architecture...". WORNUM, Ralph. The exhibition as a lesson in taste. In: THE CRYSTAL PALACE EXHIBITION. ILLUSTRATED CATALOGUE - LONDON, 1851. New York: Dover publication, 1970, p.I e JONES, Owen. The grammar of ornament. London: Day \& Son, 1856, "Leaves and flowers from nature", p.2. 
Essa condição de desqualificação é realçada na medida em que se percebe que, consoante expõe Alina Payne, nas variadas publicações de meados do século acerca das chamadas artes industriais ou decorativas, ${ }^{223} \mathrm{o}$ vocábulo Ornamento, apesar de aparecer em um grande número delas - até figurando nos títulos - não recebe quaisquer definições aprofundadas, inclusive aparecendo como sinônimo do termo mais amplo decoração, como também tampouco são esclarecidas as diferenças de sua manifestação na Arquitetura, nas artes decorativas e na indumentária. ${ }^{224}$

A imprecisão do termo Ornamento vinha se processando já desde o século anterior, uma vez que, conforme explicitam alguns estudiosos da ornamentação, em escritos de língua alemã do século XVIII, principalmente nos tratados de Arquitetura e em publicações sobre o assunto, "ornamento" [Ornament] é intercambiável com "decoração" [Zierath, Verzierung] e assim como com "adorno" [Schmuck]. ${ }^{225}$ Segundo Frank-Lothar Kroll, tal sobreposição

${ }^{223}$ No século XIX, os termos artes decorativas e artes industriais abrangiam tanto o que era chamado na época de Kunsthandwerk quanto Kunstgewerbe, em língua alemã. No Deutsches Wörterbuch de Jacob e Wilhem Grimm, publicado em Leipzig no ano de 1854 (cópia digitalizada em 33 volumes, Munique, 1984), Kunstgewerbe aparece como sinônimo de Kunstindustrie, assim como de Kunstfleisz e Kunstmanufactur. Todos eram termos cunhados mais recentemente na linguagem e refletiam as condições modernas da sociedade industrial ao se referirem a objetos que eram fabricados segundo o método da divisão das tarefas e que eram concebidos por projetistas não necessariamente pertencentes ao local de fabricação, e que por isso não se envolviam com nenhuma etapa de fatura do produto. Já o termo Kunsthandwerk está associado à Handwerk, e ambos, diferentemente de Kunstgewerbe, eram termos tradicionais, já existentes em língua alemã há alguns séculos, como se observa no Dicionário. Ainda segundo a obra dos Grimm, o verbete Handwerk indica um "opificium, ars manuaria, manu factum; obra efetuada com as mãos" [mit der Hand vollbrachte Werk]; "ofício contínuo em uma fábrica, para cuja execução excelente habilidade manual se exigiu" [dauernd betriebenes gewerbe, zu dessen ausführung vorzüglich manuelle geschicklichkeit erfordert ist]. Era o tipo de produção tradicional, tal como até o século XVIII era realizada nas corporações de ofício ou guildas. Já no verbete Kunsthandwerk, o termo é definido como "ofício que se baseia na arte, propagase no campo da arte" [handwerk das sich mit der kunst berührt, in das kunstgebiet übergreiff]. Nota-se que Kunsthandwerk diferencia-se de Handwerk na medida em que prevê um investimento artístico na obra, ou seja, o termo aponta para artefatos cujo valor de uso era secundário ao valor artístico e representativo. Na produção definida como Handwerk, pelo contrário, importava mais seu valor de uso. Durante a Idade Média, a figura do mestre de ofício era a responsável pelas etapas de fabricação - projetação e execução manual - assim como pelos tipos de produtos - arte e ofício. Com a caracterização das artes plásticas como artes liberais ao invés de mecânicas a partir do Renascimento, passam a existir artistas que somente concebem projetos de Kunsthandwerk, distanciando-se da execução, e artífices não mais responsáveis pela concepção, ficando somente incumbidos da produção manual. Esta relação foi intensificada naquela época com os meios técnicos de impressão, no caso, da gravura em madeira e em cobre. No século XIX, todas estas noções (Handwerk, Kunsthandwerk e Kunstgewerbe) eram vigentes, ainda havia oficinas, e os processos produtivos das fábricas ainda eram largamente baseados na atividade manual. Talvez o principal problema desta época estivesse com a categoria Kunstgewerbe, pois implicava na sepração entre as duas principais etapas de fabricação: a concepção e a fatura propriamente dita.

224"Este era o caso, em particular, com o termo 'ornamento', o qual aparecia em no mínimo metade dos titulos. Não somente ornamento e decoração funcionavam como equivalentes entre si, mas também nenhuma distinção era feita entre sua manifestação na arquitetura, artes decorativas e indumentária". Tradução de: "Such was the case, in particular, with the term 'ornament', which cropped up in at least half the titles. Not only did ornament and decoration function as equivalents for each other, but no distinction was made between its manifestation in architecture, decorative arts and apparel'. PAYNE, From ornament to object..., op.cit., p.30.

${ }^{225}$ Cf. KROLL, Frank-Lothar. Das Ornament in der Kunsttheorie des 19. Jahrhunderts. Hildesheim, Zürich, New York: Georg Olms Verlag, 1987; IRMSCHER, Günter. Kleine Kunstgeschichte des europäischen 
contribuiu para a construção da ideia de Ornamento como algo meramente acessório:

...na teoria do ornamento do século 18, a equiparação, tão evidente e etimologicamente inteiramente substituível dos conceitos 'ornamento', 'adorno' e 'decoração' muito dificulta uma discussão apropriada sobre a essência, o valor e o significado do ornamento precisamente por causa de tais 'conotações' etimológicas (e também de conteúdo). A partir do sentido da palavra, a classificação do ornamento como 'mero' acessório parece ser não somente compreensível, mas também quase inevitável. ${ }^{226}$

Já a ausência de distinção entre o Ornamento usado na Arquitetura, daquele empregado pelas artes decorativas e pela indumentária ${ }^{227}$ evidencia, pode-se dizer, o fato de, em meados do século XIX, segundo aponta Payne, "a conexão entre as chamadas artes 'menores', ou decorativas, e as artes 'maiores' permaneceu, quando reconhecida, uma questão aberta e geralmente desconfortável". ${ }^{228}$ Assim, tendo em vista esse panorama de imprecisão e indefinição do Ornamento, Payne aponta os efeitos que se processaram ao longo de todo o século: "esta ampla e vagamente circunscrita categoria "ornamento", que veio a levar uma existência semi-autônoma, ficou cada vez mais sob pressão, e começava-se a sentir alguma urgência para esclarecer as questões". 229

O arquiteto e teórico Gottfried Semper insere-se no grupo desses que, em torno de meados do século, procuraram elucidar tais questões, assim como

Ornaments seit der frühen Neuzeit (1400-1900), op.cit. e também SCHÜTTE, Ulrich. Ordnung und Verzierung..., op.cit..

226“...die in der Ornamentheorie des 18.Jahrhunderts so selbstverständliche und etymologisch durchaus vetretbare Gleichsetzung der Begriffe 'Ornament', 'Schmuck' und 'Verzierung' eine sachgerechte Diskussion über Wesen, Wert und Bedeutung 'des' Ornaments gerade wegen solch etymologischer (und damit zugleich inhaltlicher) 'Vorbelastungen' stark erschwert. Vom Wortsinn her scheint die Klassifizierung des Ornaments als eine 'bloßer' Zutat nicht nur verständlich, sondern fast schon unvermeidlich zu sein". KROLL, Das Ornament in der Kunsttheorie des 19. Jahrhunderts, op.cit., p.12, aspas e grifo do autor.

${ }^{227}$ O estudioso Karl Philipp Moritz (1756-1793), por exemplo, em Vorbegriffe zu einer Theorie der Ornamente (Berlin: Karl Matz-Dorff's, 1793), não somente usa, dentre outros termos, "ornamento" [Ornament] e "decoração" [Zierrath] como sinônimos - conceitos que ele caracteriza como algo supérfluo - , mas também inclui sob essa designação uma variedade de elementos como objetos domésticos, roupas, fivelas, botões, entre outros. De acordo com ele (Ibid., p.18): "Sob [o termo] decoração imaginamos, por assim dizer, o supérfluo sobre uma coisa, por meio do qual ela não se torna mais útil do que já era, mas sim agrada melhor aos olhos". Tradução de "Unter Zierrath denken wir uns dasjenige gleichsam Überflüssige an einer Sache, wodurch sie nicht nützlicher wird, als sie schon war, sondern nur besser ins Auge fällt'.

228 "...the connection between the so-called 'minor', or decorative, and 'high' arts remained an open and often uneasy, if acknowledged, question". PAYNE, From ornament to object..., op.cit., p.28.

$229 " . .$. this broadly and vaguely circumscribed category 'ornament', which had come to lead a semiautonomous existence, came increasingly under pressure, and some urgency to clarify the issues was beginning to be felf". Ibidem, p.30. 
restabelecer o status quo do Ornamento, sobretudo do Ornamento arquitetônico. Entretanto, não se pode reduzir sua teoria do Ornamento a uma afirmação simplista de que ele procurou restabelecer ali os sentidos provenientes da Tradição Clássica em Arquitetura. Suas referências na Tradição são fundamentadas na epistemologia e nos problemas da época em que Semper viveu, e trouxeram importantes contribuições para a história e teoria da Arquitetura e das artes no geral. ${ }^{230}$

O presente capítulo pretende demonstrar como Gottfried Semper insere o Ornamento arquitetônico em uma genealogia histórica e evolutiva de surgimento e desenvolvimento das artes. Semper historiza o Ornato, localizando sua origem antes no adorno do que na escultura, ou seja, nas 'artes menores' ao invés das 'maiores', além de consagrar a ele uma importância indispensável para os indivíduos e suas instituições sociais. O Ornamento é origem da arte para o estudioso hamburguês, e, na teoria semperiana, ele encarna aquilo que Heinz Quitzsch apontou como sendo "a matéria da arte" para Semper: "a vida humana nas suas diversas formas". 231

\subsection{Adorno e ritual: a constituição da individualidade}

A estudiosa Mari Hvattum associa o discurso de Semper sobre as origens das artes a uma herança do século XVIII e seu "interesse pelas causas primeiras e a sua - intimamente relacionada - obsessão com as origens, então perseguida em toda disciplina". 232 De fato, a partir do século XVIII, particularmente considerando-se a emergência e consolidação do pensamento iluminista, nota-

\footnotetext{
230 Acerca do legado de Semper para a teoria e a prática da Arquitetura, conferir The Semper legacy: Semper and Riegl in: MALLGRAVE, Harry Francis. Gottfried Semper: architect of the nineteenth century. New Haven: Yale University Press, 1996, pp.355-381.

231 Segundo Quitzsch, "a matéria da arte, quer dizer, na sua interpretação, o homem como indivíduo e o homem na família, o homem coletivo como Estado e a humanidade como ideal, é, portanto, a vida humana nas suas diversas formas". Tradução de "La materia dell'arte, cioè nella sua interpretazione, l'uomo come individuo e l'uomo nella famiglia, l'uomo collettivo come Stato e l'umanità come ideale, è dunque la vita umana nelle sue diverse forme". QUITZSCH, Heinz. La visione estetica di Semper. Trad. Daria Rescaldani. Jaca Book: Milano, 1991, p.48.

232"[ the eighteenth century can be characterised in part by the growing] interest for the first causes and the near obsession with origins, pursued in every discipline". HVATTUM, Mari. Gottfried Semper and the problem of historicism. Cambridge: Cambridge University Press, 2004, p.30.
} 
se a recorrência, em vários campos do saber, de estudos que buscavam as origens de valores, hábitos e práticas culturais dos indivíduos. ${ }^{233}$

Tratava-se de uma forma de se construir princípios explicativos que não bastavam somente enquanto pensamento teórico, pois em muitos campos serviam para fundamentar, além do julgamento, também a ação. E pode-se dizer que o que fornecia a garantia destes princípios era não somente a suposta certeza das origens, mas também a explicação dos processos históricos que eles ilustravam. Ao invés dos saberes e das práticas estarem fundamentados em antigos mitos e lendas, busca-se, a partir de então, a compreensão científica por via da historicidade dos fenômenos, dos eventos, dos grupos humanos e das coisas que cercam o mundo dos indivíduos. Pode-se dizer que, entre os setecentos e os oitocentos, estava-se diante do florescer de um novo sentido da história que ganharia legitimidade enquanto construção do conhecimento em diferentes áreas do saber. ${ }^{234}$

Mas, nessa nova forma de conhecimento histórico, o mito não foi completamente descreditado. Ele é investigado particularmente a partir do século XIX e sobretudo com o avanço dos estudos em Antropologia. Conforme esclarece Mircea Eliade, apesar de parecer ir de encontro ao espírito científico que vigorou no século XIX, o mito passa a ser valorizado nos estudos sobre os grupos ditos primitivos, justamente por ser a "revelação" de certa verdade absoluta, originária, e, deste modo, por permitir reviver ou recriar algum tipo de experiência primordial. ${ }^{235}$ Tomada como explicação plausível do passado, logo,

\footnotetext{
${ }^{233}$ Sobretudo tendo em vista o contexto de uma tradição que a muitos parecia duvidosa, a busca das origens tornou-se necessária para legitimar o presente e também justificar as propostas de mudanças. Dentre as investigações que surgiram na época, podem ser citados, por exemplo, os estudos sobre a origem da linguagem de Johann Gottfried Herder (1744 - 1803), sobre a origem da fé religiosa de David Hume (1711 - 1776) e sobre a natureza do bom de Denis Diderot (1713 - 1784).

${ }^{234}$ Foi devido às novas perspectivas proporcionadas pela chamada "Ciência Nova" de Giambattista Vico (1688-1744) que, especialmente a partir do século XVIII, se pode pensar em uma forma de conhecimento histórico. Vico, contrapondo a defesa de Descartes da matemática como única forma de conhecimento possível, formada a partir de leis naturais e imutáveis, coloca o homem no centro de suas investigações, enquanto agente que cria e sofre, enquanto, ao mesmo tempo, sujeito e objeto de conhecimento. As fontes de investigação de Vico, objetos filológicos, muitos comumente associados ao mundo da fantasia e da imaginação - e por isso, desconsiderados pelos estudiosos até então - como mitos, relatos bíblicos e fábulas, foram tomados por ele como fontes de conhecimento legítimas que deveriam ser interpretadas para construir um patamar de verdade científica. Posteriormente, com o movimento romântico alemão, as ideias colocadas pioneiramente por Vico foram mais desenvolvidas. Ao ideal abstrato das ciências naturais, os estudiosos afirmaram a contingência da experiência humana e a especificidade das sociedades, de sua cultura e instituições. Para compreender os sentidos desta nova consciência histórica no caso da arquitetura, conferir COLQUHOUN, Alan. Três tipos de historicismo. In: Modernidade e tradição clássica: 1980-1987. SP: Cosac \& Naify, 2004, pp.23-37.

235 ELIADE, Mircea. Mitos, sonhos e mistérios. Lisboa: Edições 70, 2000. Ainda Eliade esclarece que o mito "conta uma história sagrada; ele relata um acontecimento ocorrido no tempo primordial, o tempo fabuloso do princípio. Em outros termos, o mito narra como, graças as façanhas dos Entes Sobrenaturais, uma
} 
também das origens, a construção mítica torna-se um meio viável da escrita concebida como científica.

O discurso de Semper acerca da origem das artes é construído aos moldes de uma argumentação mítica em torno dos indivíduos primitivos. Já desde sua época de estudante ele tinha conhecimento dos recentes estudos antropológicos sobre os mitos, pois na década de vinte, em uma estadia na universidade de Göttingen, ${ }^{236}$ teve a oportunidade de assistir algumas conferências do arqueólogo Karl Otfried Müller (1797-1840) acerca da mitologia antiga. ${ }^{237}$ No entanto, de acordo com a historiografia sobre Semper, ${ }^{238}$ a principal referência desta sua construção sobre as origens foram os escritos do etnólogo de língua alemã Gustav Klemm (1802-1867),239 com cuja obra ele teve proximidade durante seus anos de professor em Dresden. ${ }^{240}$

Klemm é responsável pela elaboração de uma vasta obra literária, em dez volumes, ${ }^{241}$ que tinha a pretensão de abarcar uma "história cultural da humanidade". ${ }^{242}$ Neste estudo, ele apresenta o que compreendia como o padrão

realidade passou a existir, seja uma realidade total, o Cosmos, ou apenas um fragmento: uma ilha, uma espécie vegetal, um comportamento humano, uma instituição. É sempre, portanto, uma narrativa de 'criação': ele relata de que modo algo foi produzido e começou a ser'. ELIADE, Mircea. Mito e Realidade. Ed. 4. Trad. Pola Civelli. São Paulo: Perspectiva, 2011, p.11, aspas e grifo do autor.

${ }^{236}$ Semper frequentou essa universidade a partir de 1823, momento em que ele se inscreveu em aulas sobretudo de matemática e história moderna. Por insatisfação com os cursos, em 1825 ele abandona a universidade e a cidade de Göttingen. Acerca deste assunto e da trajetória de estudante de Semper, conferir MALLGRAVE, Gottfried Semper: architect of the nineteenth century, op.cit., pp.11-65.

237 Müller na década de vinte era um dos importantes estudiosos da Antiguidade clássica e usou a mitologia como fonte para construir uma visão compreensiva da história antiga, distinta daquela dos literatos. Grande parte do conteúdo de seus estudos foi compilado em seu Handbuch der Archäologie der Kunst (Breslau: Josef Max und Komp Verlag, 1830), obra que Semper cita em seu Der Stil.

238 Conferir, sobretudo: MALLGRAVE, Gottfried Semper. architect of the nineteenth century, op.cit., e (do mesmo autor) Gustav Klemm and Gottfried Semper: the meeting of ethnological and architectural theory. In: RES: Anthropology and Aesthetics, New York, London: Cambridge university press, 1985, v.9, pp.68-79. Também HVATTUM, Gottfried Semper and the problem of historicism, op.cit.

239 Estudioso que, por volta da década de quarenta do século XIX trabalhava como bibliotecário real da corte da Saxônia em Dresden e que, segundo Mari Hvattum, referenciando-se em J. Leopold, é "celebrado como um dos pais da moderna antropologia, introduzindo o termo cultura em um sentido aproximadamente moderno". Tradução de "[he is] celebrated as one of the fathers of modern anthropology, introducing the term culture in an approximately modern sense". HVATTUM, Mari.Gottfried Semper and the problem of historicism, op.cit., p. 43. Conferir também trechos da obra original citada por Hvattum, J. Leopold, Culture in comparative and evolutionary perspective: E. B. Tylor and the making of primitive culture. Berlin: Reimer: 1980, pp.67-90.

240 No primeiro volume do Der Stil, Semper menciona diretamente os estudos de Klemm, primeiramente acerca do posicionamento deste último, em sua obra Kulturgeschichte (referenciada a seguir), sobre os habitantes das ilhas do Pacífico Sul, e depois, sobre uma obra posterior do etnólogo, denominada Allgemeine Kulturwissenschaft. Conferir SEMPER, Der Stil, vol. I, 1860, op.cit., p. 98 e p. 102. Essas menções a um colega estudioso consistem em raras exceções, pois, conforme colocam Harry F. Mallgrave e Wolfgang Herrmann, Semper raramente citava e referenciava suas fontes. Cf. MALLGRAVE, Gustav Klemm and Gottfried Semper, op. cit., assim como HERRMANN, Gottfried Semper: in search of architecture, op.cit.

${ }^{241}$ KLEMM, Gustav. Allgemeine Kulturgeschichte der Menschheit. Leipzig: Teubner: 1843-1852.

242 Como pode ser compreendido pelo próprio título de sua obra. 
de desenvolvimento humano, ${ }^{243}$ que tem como referência noções de raça e de cultura. $^{244}$ Dentre seus temas de investigação estão os costumes, crenças, hábitos, artefatos, e outros aspectos culturais dos homens, examinados desde os primórdios, ou seja, desde as culturas primitivas.

Em termos das manifestações artísticas, Klemm acredita que toda arte se constituía, em essência, em uma fundamental necessidade humana de representação. Essa necessidade é caracterizada por ele como sendo um impulso ou instinto artístico, ${ }^{245}$ que ordenava e dava forma ao universo particular humano. Assim como outras manifestações culturais, a arte estava presente desde os primórdios do homem e seguia um processo evolutivo que acompanhava o desenvolvimento dos grupos sociais:246

nós encontramos os princípios da arte nos mais baixos estágios da cultura, onde nós também encontramos os princípios dos estados, posto que o homem tem o instinto de representar externamente o que a ele acontece, o que a ele se apresenta, e com estas representações adornar seu ambiente. ${ }^{247}$

O estágio mais inferior da arte se manifestava em expressões como os nós de um cordão ou trama têxtil, em um colar de contas, danças ritualísticas e também na pintura corporal (figura 5). Estas expressões artísticas primordiais,

243 Está implícita nesta ideia a noção de progresso, um dos paradigmas teóricos do século XIX. Segundo Reinhart Koselleck, o conceito de progresso foi criado e difundido a partir de fins do século XVIII e ele subentendia nessa época "o objetivo de uma perfeição possível, que antes só podia ser alcançado no além", mas que a partir de então é temporalizado e mundanizado, implicando um horizonte de expectativa que passa a incluir como pressuposto a busca por melhoramento, aperfeiçoamento. A partir de então, coloca o autor, "toda a história pôde ser concebida como um processo de contínuo e crescente aperfeiçoamento; apesar das recaídas e rodeios, ele [o progresso] teria que ser posto em prática pelos homens". KOSELLECK, Reinhart. Futuro passado: contribuição à semântica dos tempos históricos. Tradução Wilma Patrícia Mass, Carlos Almeida Pereira. RJ: Contraponto, Puc-Rio, 2006, pp.316 e 317 respectivamente, colchetes nossos.

244 Segundo Mallgrave, Klemm compreende o desenvolvimento da humanidade em um processo que envolvia três fases: selvageria, domesticidade e liberdade. Subjacente a estes estágios está a noção de raça de Klemm que implica uma diferenciação entre raças passivas - americanos, indianos, africanos, egípcios, entre outros - e ativas, que corresponderia às tribos linguísticas indo-européias e que teriam dominado as raças passivas, resultando em um processo de fusão cultural equilibrada em cada sociedade. MALLGRAVE, Harry Francis. Gustav Klemm and Gottfried Semper, op.cit. Ainda nesta obra (p.73), Mallgrave afirma que a obra de Gustav Klemm se tratou do "maior estudo antropológico a examinar o homem fora da estrutura bíblica", cujo discurso era dominante até o momento. Tradução de: "Certainly it was the major anthropological study to examine man outside the biblical framework".

245 Kunsttrieb. Para Mari Hvattum, o Kunsttrieb de Klemm antevia o Kunstwollen do historiador vienense Alois Riegl. Cf. HVATTUM, Gottfried Semper and the problem of historicism, op.cit., p.44.

246 Este dependia da raça e da fase evolutiva de cada grupo social.

${ }^{247}$ Tradução de "Die Anfänge der Kunst finden wir aus den niedrigsten Stufen der Cultur, wo wir auch die Anfänge des Staates fanden, indem der Mensch den Trieb hat, das was ihm vorgeht, was ihm erscheint, nach Aussen darzustellen und mit diesen Darstellungen seine Umgebung zu schmücken“. KLEMM, Allgemeine Kulturgeschichte der Menschheit, op.cit., vol.1, p.214. 
segundo o autor, estavam associadas ao surgimento da vida coletiva, da vida em comum e portavam os valores sagrados dos mitos:

quanto mais a vida social se forma em vida do povo, em estados, em teocracia, mais nós vemos surgir meios de auxílio para proteção e o cuidado dos valores de despertar, por conseguinte também o mito. Semelhantes meios de auxílio são os nós, os quais os de Otdia tecem em cordões, para se memorizar coisas, os nós cronológicos dos negros no Congo e as contas de concha dos índios norteamericanos. Por fim deve-se também mencionar a dança como suporte do mito; a dança - não se trata de algo no sentido do mundo moderno dos salões - mas sim como representação plástica, como narrativa mímica de realidades ordenadas. $^{248}$

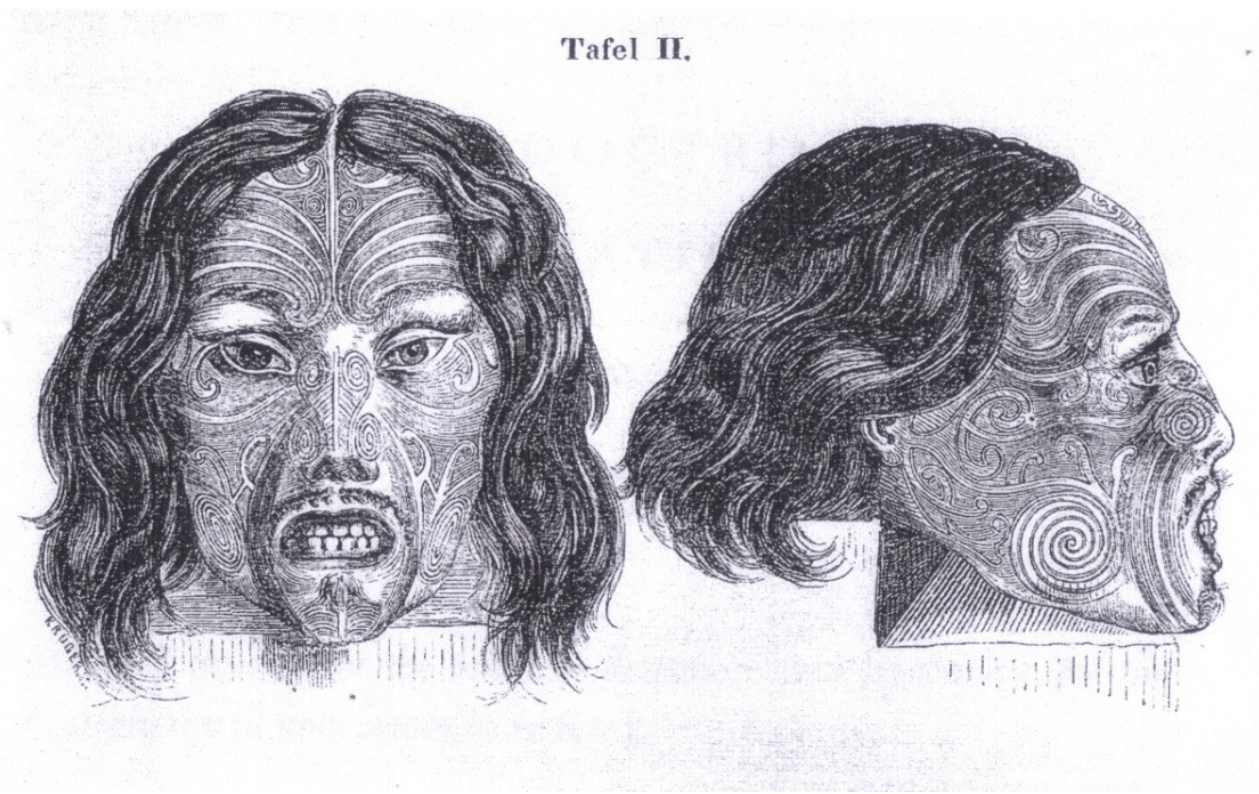

Figura 5 - Gravura da obra de Gustav Klemm, representando as tatuagens faciais de homens primitivos. Fonte: HVATTUM, Gottfried Semper and the problem of historicism,2004.

O pensamento de Semper sobre a origem das artes é muito semelhante ao de Klemm. ${ }^{249}$ Nos prolegômenos de sua extensa obra Der Stil, local onde ele

\footnotetext{
248 KLEMM, op.cit.,vol.1, pp.2-3. Tradução de "Je mehr sich das gesellschaftliche Leben zum Volksleben, zum Staate, zur Theocratie ausgebildete, desto mehr Hülfsmittel zu Bewahrung und Pflege des Wekenswerthen, mithin auch der Sage, finden wir entstehen. Dergleichen Hülfsmittel sind die Knoten, die man aus Otdia in Schnuren knüpfen, um sich Namen zu merken, die chronologischen Knoten der Neger in Kongo und die Wampums der nordamericanischen Indianer. Endlich ist noch der Tanz als Träger der Sage zu nennen; der Tanz - doch nicht etwa in der Bedeutungslosigkeit der modernen Salonwelt - sondern als plastiche Darstellung, als mimische Erzählung einer Reihe Thatsachen".

249 Mallgrave, acerca dos pontos de contato de Semper com a teoria de Klemm, coloca que: "[...] suas muitas generalizações sobre as condições raciais, sociais e políticas das primeiras civilizações eram reunidas na maior parte a partir dos importantes historiadores alemães da primeira metade do século dezenove, cujas explicações, por sua vez, eram baseadas principalmente nos esforços dos autores clássicos". Tradução de "Their many generalizations on the racial, social, and political conditions of early civilizations were gathered for the most part from the major German historians of the first half of the
} 
apresenta sua compreensão da origem das manifestações artísticas, Semper associa os primórdios da atividade artística a uma condição psicológica dos indivíduos primitivos, que ele, assim como Klemm, chama de "instinto ou impulso artístico", ou, também como sinônimos, "sentido da beleza", "prazer na beleza" e "prazer artístico".250

Esse indivíduo primitivo, tanto em Semper como também em Klemm, consiste no homem primitivo contemporâneo a eles, que estava sendo investigado pelos estudos antropológicos e que, a partir de um olhar eurocêntrico comum à época, é avaliado como primitivo por supostamente não ter se desenvolvido suficientemente, principalmente em termos materiais, ou seja, não acompanhou o progresso das outras culturas. ${ }^{251}$ Apesar desta abordagem eurocêntrica, o instinto de que trata Semper não é simplesmente motivado por uma determinação material e tampouco era restrito aos indivíduos primitivos. Pelo contrário, esse instinto era um atributo de todos os indivíduos, somente sua manifestação é que era mais "clara" e "pura" nas condições primitivas. E, nestas condições, o teórico afirma que ele era análogo aos

instintos, prazeres e satisfações através dos quais a conservação da existência telúrica comum é condicionada, e os quais, considerado exatamente, podem ser atribuídos à dor e sua momentânea eliminação, entorpecimento ou esquecimento. ${ }^{252}$

Ou seja, Semper compara o instinto artístico àquele que visa satisfazer as necessidades primárias do homem - como progetegê-lo do frio e saciá-lo da fome - e que o leva muitas vezes a produzir artefatos para aliviar tais desconfortos, como, por exemplo, abrigos. ${ }^{253} \mathrm{~A}$ analogia entre ambos se deve ao fato de que os dois procuravam, cada um a seu modo - um deles refere-se à

\footnotetext{
nineteenth century, whose accounts in turn were based largely on the efforts of classical authors". MALLGRAVE, Gustav Klemm and Gottfried Semper, op.cit., p.74.

250 Kunsttrieb, Schönheitsinn, Freude am Schönen e Kunstgenuss, respectivamente. SEMPER, Der Stil, vol.I, op.cit.,p.XXI.

251 Como coloca Rykwert, para Semper "a palavra primitivo geralmente refere-se aos povos primitivos que eram seus contemporâneos, não aqueles da Idade da Pedra. Ele conhecia esta arte "primitiva" por meio de museus e descrições; ele estendeu seu conhecimento por analogia aos homens de anos muito anteriores". Tradução nossa de "...the word most usually refers to the 'primitive' people who were his contemporaries, not those of the Stone Age. He knew such 'primitive' art through museums and descriptions; he extended his knowledge by analogy to the men of much earlier ages". RYKWERT, Gottfried Semper and the conception of style. In: The necessity of artifice, op.cit., p.124.

252“...Trieben, Genüssen und Befriedigungen, durch welche die Erhaltung des gemeinen tellurischen Daseins bedungen ist, und die, genau betrachtet, sich auf Schmerz und dessen momentanes Beseitigen, Betäuben oder Vergessen zurückführen lassen". SEMPER, Der Stil, vol. I, op.cit.,p.XXI. 253 Id. Ibid.
} 
existência telúrica do homem, o outro à existência espiritual, pode-se dizer aliviar os efeitos das circunstâncias hostis do meio, como, por exemplo, da imensidão de um universo frente à condição humana. ${ }^{254}$

E o meio privilegiado pelo qual esse indivíduo procura mitigar as agruras de sua existência é o ritual sagrado. ${ }^{255}$ Assim Semper descreve a condição primitiva nos prolegômenos do Der Stil:

cercado por um mundo cheio de maravilha e forças, cuja lei o homem pressente, que ele gostaria de compreender, mas nunca decifra, que somente toca-o em poucos acordes fragmentários e mantém sua alma continuamente em insatisfatória tensão, ele faz aparecer a si no jogo, como que por mágica, a perfeição faltante, cria para si um mundo em miniatura, no qual a lei cósmica, em estreita limitação, mas em si mesma completa e neste respeito perfeita, se evidencia; neste jogo ele satisfaz seu instinto cosmogônico. ${ }^{256}$

Trata-se, pode-se dizer, do que Mircea Eliade chama de um "esboço cosmogônico" 257 , ou seja, essa descrição de Semper, ao referir-se à criação do mundo material do homem - o mundo em miniatura -, recorda a criação do universo, no sentido que, pode-se afirmar, ela "pressupõe e prolonga a cosmogonia". 258 Isto porque o indivíduo primitivo tenta reproduzir as obras exemplares de um deus demiurgo, aquilo que é concretizado no que se entende por cosmos, totalidade perfeita da criação. E é no ritual religioso que ocorre essa experiência, pois os cultos sagrados, em suas diversas expressões, constituem a atualização e reiteração, por seus participantes, dos mitos de origem, dos feitos exemplares dos deuses. ${ }^{259}$

No ritual, o homem não está somente fabricando um artefato, é como se ele estivesse operando "uma recriação mágica do mundo"260, imitando o gesto criador original e com isso conferindo ordem, harmonia a seu universo. Ainda

\footnotetext{
${ }^{254}$ No Der Stil (vol.I, op.cit.), o autor afirma não saber exatamente qual dos dois instintos surgiu primeiro. 255 Consoante Mircea Eliade, "a principal função do mito consiste em revelar os modelos exemplares de todos os ritos e atividades humanas significativas". ELIADE, Mircea. Mito e Realidade, op.cit., 2011, p. 13. 256"Umgeben von einer Welt voller Wunder und Kräfte, deren Gesetz der Mensch ahnt, das er fassen möchte, aber nimmer enträthselt, das nur in einzelnen abgerissenen Akkorden zu ihm dringt und sein Gemüth in stets unbefriedigter Spannung erhält, zaubert er sich die fehlende Vollkommenheit im Spiel hervor, bildet er sich eine Welt im Kleinen, worin das kosmische Gesetz in engster Beschränktheit, aber in sich selbst abgeschlossen, und in dieser Beziehung vollkommen, hervortritt; in diesem Spiel befriedigt er seinen kosmogonischen Instinkt'. " SEMPER, Der Stil, vol.I, op.cit., p.XXI.

${ }^{257}$ ELIADE, Mito e Realidade, op.cit., p37.

258 Id.lbid., p.25.

259 Id.lbid.

260 Id.lbid., p.28.
} 
Mircea Eliade esclarece que, na concepção primitiva, "fazer bem alguma coisa, trabalhar, construir, criar, estruturar, dar forma, in-formar, formar - tudo isso equivale a trazer algo à existência, dar-lhe 'vida' e, em última instância, fazê-la assemelhar-se ao organismo harmonioso por excelência, o Cosmos". ${ }^{261}$

O instinto cosmogônico a que se refere Semper é o instinto artístico, pois a arte reproduz as leis do cosmos, da natureza, dando ordem ao universo particular do homem. A arte é, deste modo, uma atividade que, para Semper, surge das circunstâncias do ritual sagrado e é essencialmente simbólica. ${ }^{262} \mathrm{E}$ como esse instinto artístico é inerente ao homem, ou seja, está presente no indivíduo não importa a que época ele pertença - é uma faculdade inclusive dos homens do século XIX - a arte está sempre recriando o mundo; o discurso de Semper, nesse sentido, procura legitimar a atividade artística como algo intrínseco e, por isso, fundamental ao homem enquanto ser no mundo.

Das práticas primitivas desenvolvidas no culto, Semper aponta algumas e notam-se aí prováveis referências em Gustav Klemm:263

por meio da regularidade de uma sequência periódica de espaço e tempo, na coroa, no colar de pérolas, no arabesco, em uma dança ritualística, nos sons rítmicos com os quais a dança ritualística é acompanhada, na cadência do remo, e por aí vai. ${ }^{264}$

Logo, como manifestações artísticas primordiais estariam a dança, a música e os artefatos de adorno. Dentre essas práticas, Semper, como arquiteto, confere maior atenção ao adorno, ou Ornamento - dois termos que, seguindo a predisposição comum de sua época, o teórico utiliza de modo intercambiável em muitos de seus escritos e muitas vezes usa-os também como sinônimo de decoração. ${ }^{265}$

\footnotetext{
${ }^{261}$ Id.lbid., p.35, aspas do autor.

262 "Sem dúvida a arte sem piedade não existe: a piedade faz o homem ter prazer nos seres que o Artífice criou; ela o conduz, arrebatado, a se expressar criativamente e como uma divindade em sua própria obra". Tradução nossa de "No doubt true art without piety does not exist: piety causes man to take delight in the living beings that the Maker has created; it drives him, enraptured, to express himself creatively and like a deity in his own work". SEMPER, Gottfried. The basic elements of architecture. In: HERRMANN, Wolfgang. Gottfried Semper: in search of architecture, op.cit., p.196.

${ }^{263}$ Semper não cita o estudioso como uma de suas fontes neste tema.

264 “....durch die Regelmässigkeit periodischer Raumes - und Zeitfolgen [...], im Kranze, in der Perlenschnur, im Schnörkel, im Reigentanze, in den rhythmischen Lauten womit der Reigentanz begleitet wird, im Takte des Ruders, u.s.W....". SEMPER, Der Sti, vol. I, op.cit., p.XXII.

265 O teórico, de um modo geral, não se mostra preocupado com o rigor filológico dos termos usados em seus textos. Isto ocorre também entre Architektur e Baukunst, usadas de modo intercambiável pelo autor.
} 
No ritual, ao adornar a si mesmo e às coisas ao redor, evidencia-se a "mágica" do jogo, na qual se dissimula a vulgaridade da condição humana primitiva, o estado de natureza. Isto porque, ao adornar-se ou adornar o que o cerca, o homem se distingue do mundo natural - pois, consoante Semper, "nenhum animal adorna a si mesmo"266 _, assim como "anima" o mundo ao redor. Trata-se, pode-se dizer, de uma distinção entre cultura e natureza. Consoante Semper:

no adornar busca-se expressão daquela aspiração por individualidade, aquele sentido de separação, que é inerente ao homem e que é um dos dois principais momentos do desenvolvimento humano; qualquer coisa que eu adorne, seja isto animado ou inanimado, uma parte ou um todo, eu dou a ele um direito próprio de existência; - quando eu o faço o foco das relações que primeiramente valem somente a ele, ele é elevado a [nível de] uma pessoa. ${ }^{267}$

Tanto o adorno, quanto a dança e a música ordenam o universo por meio da expressão de sequências rítmicas, constantemente recapituladas no ritual. ${ }^{268}$ Se de um lado o indivíduo em seu gesto criador produz uma impressão de movimento - e, consequentemente, de tempo -, pelos sons e pela ordenação sequencial produzidos na dança e na música, de outro, ao fabricar um objeto, ele age recriando o mundo, como afirma o autor, um "mundo em miniatura para si”. ${ }^{269}$ O ritmo, deste modo, ao estabelecer relações sequenciais entre partes, seria o mais simples princípio ordenador próprio ao instinto cosmogônico. De acordo com Hvattum, nessas ações rítmicas tem-se uma espécie de "reificação do tempo e do movimento", a qual possui sua "incorporação tangível", não exatamente na música e na dança, mas principalmente nos artefatos de adorno. ${ }^{270}$

\footnotetext{
266“...kein Thier schmückt sich...”. SEMPER, Gottfried. Über Baustyle. Zurich: Druck und Verlag von Friedrich Schultess, 1869 , p.13.

267“Im Schmücken sucht sich jenes Streben nach Individualität, jener separatistischer Sinn, der dem Menschen innewohnt und eines der beiden Hauptmomente menschlicher Entwicklung ist, Ausdruck zu verschaffen; denn was ich schmücke, sei es belebt oder leblos, Theil oder Ganzes dem ertheile ich eine eigene Lebensberechtigung; - indem ich es zu einem Mittlepunkte der Beziehungen mache,die zunächst nur ihm gelten, wird es zu einer Person erhoben." Ibid., p.13.

268 SEMPER, Der Stil, vol. I, op.cit.

269 Cf. nota 256.

270"reification of time and movement" e "tangible embodiment". HVATTUM, Gottfried Semper and the problem of historicism, op.cit., p.66.
} 
Para Semper, o adorno é um ofício, é Kunst, do modo como etimologicamente significa esse conceito em alemão. ${ }^{271}$ Semper acredita que o ofício originário é proveniente da técnica têxtil, ou seja, do trançar, entrelaçar. ${ }^{272}$ Não que esta técnica tivesse sido a primeira a ser explorada, mas pelo fato de que, além de certamente ela se encontrar nos primórdios da atividade fabricadora do homem, ela teria sido o ponto de partida de toda filiação artística posterior e, com isso, teria fornecido os princípios artísticos fundamentais das artes - como o ritmo, por exemplo. Isto porque sua matéria-prima, inicialmente ramos e fibras naturais, além de ser de fácil manuseio - adequada para criar uma sequência ritmada, por exemplo -, mostava-se mais disponível no ambiente do indivíduo primitivo; daí a referência de Semper à coroa, ao colar e ao arabesco, todos artefatos fabricados com estes tipos de materiais naturais. Uma coroa, por exemplo, seria resultado da simples junção e do trançado rítmico de ramos de folhas ou flores (figura 6).

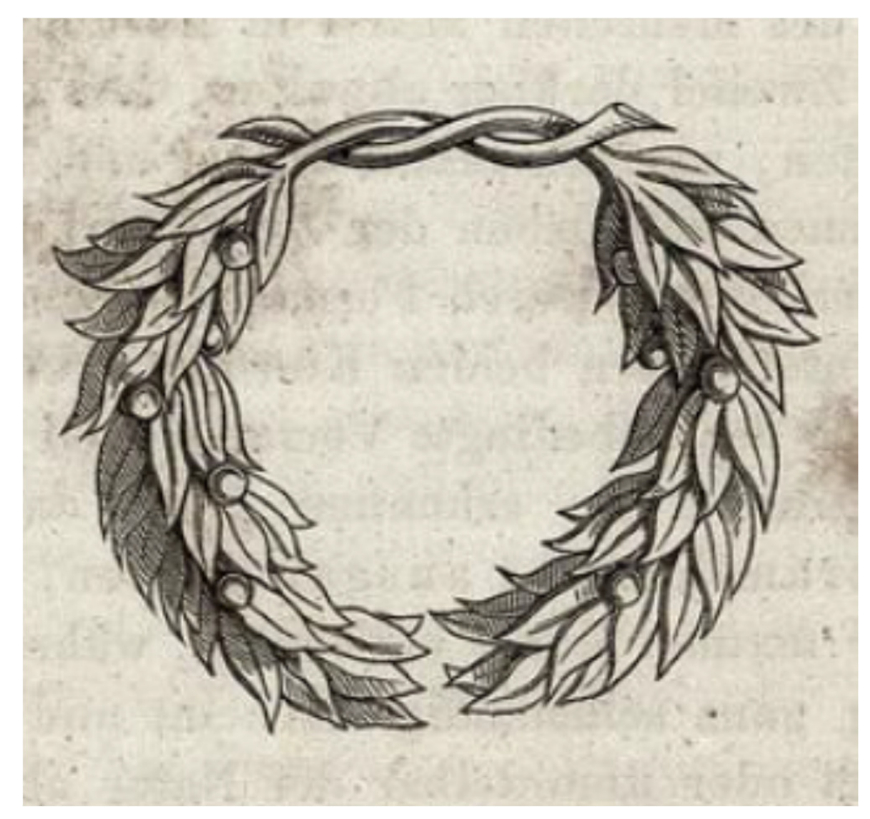

Figura 6 - Coroa de folhas, desenho de Semper. Fonte: SEMPER, Der Stil, vol. I, 1860.

\footnotetext{
271 Kunst estaria associada à palavra Können (inicialmente Künnen, depois Kunnen). Tal palavra referir-seia primeiramente a um saber, uma forma de conhecimento - daí Kennen [conhecer]. Können também designaria um poder, no sentido de uma habilidade [Geschichlichkeit]. GRIMM, Jacob e Wilheim. Deutsches Wörterbuch,op.cit. Verbete Kunst.

272“...[a arte têxtil] revela-se deste modo como uma arte originária..... Tradução de "[...der textilen Kunst...] sie sich dadurch gleichsam als Urkunst zu erkennen gibt...”. SEMPER, Der Stil, vol.I, op.cit., p.13.
} 
Como em todo ofício pensar e fazer encontram-se associados, Semper acredita que os adornos eram motivados por uma dupla necessidade, ou uma necessidade com dois vieses, implícitos na sua fatura: além do aspecto utilitário de todo ofício, há no adorno ma necessidade estética, de embelezamento, e uma necessidade sagrada, de conferir ordem ao universo. Ao trançar ritmicamente as flores de uma coroa, o indivíduo está reproduzindo a harmonia cósmica e ao mesmo tempo embelezando. Ou seja, ao embelezar ele está simbolicamente ordenando o universo. Semper retoma aqui, a seu modo, tema recorrente da Tradição, já sugerido no tratado de Vitrúvio, a associação entre beleza, ordem e Ornato.

Mas, apesar desta referência em noções tradicionais, o discurso de Semper traz contribuições que não faziam parte do universo das preceptivas clássicas. Considerando o fundamento antropológico de sua investigação, e conforme se pode deduzir do exposto até então, a beleza e as leis cósmicas, ao invés de terem surgido na prática artística com os gregos, já eram intuídas pelos indivíduos primitivos. Essa beleza ordenadora consiste em uma beleza formal para o teórico, seguia leis formais, as quais já estariam evidentes na natureza, por exemplo, no corpo humano ou nos outros seres naturais. ${ }^{273} \mathrm{O}$ que o adorno faria era reforçar estes princípios no elemento adornado, pois, coloca 0 estudioso, "onde o homem adorna, simplesmente ele destaca mais claramente, com uma ação mais ou menos consciente, a legalidade da natureza nos objetos que ele decora". ${ }^{274}$

Dentre estas leis, Semper refere-se mais especificamente à quatro, três das quais consistem em uma reinterpretação de termos explorados no tratado

\footnotetext{
${ }^{273}$ Não se trata aqui de a arte imitar mecanicamente a natureza, mas sim reproduzir o modo como ela cria, sua força criadora. Essa ideia, que sugere a noção tradicional de uma natura naturans, segundo esclarece Harry F. Mallgrave (The idea of style, op.cit.), foi despertada em Semper a partir dos escritos de F.W.J. Schelling, pela via indireta do historiador Karl Friedrich von Rumohr. Conforme o sistema das artes elaborado por Schelling, coloca Moraes Barros, "é essa natureza viva e criadora que o artista deve, a seu modo, reproduzir, e não o produto natural totalmente privado de significação. Deve, pois, afastar-se do produto ou da criatura, para 'elevar-se à força criadora"”. MORAES BARROS, Fernando R. de. Introdução. In: SCHELLING, F.W.J. Sobre a relação das artes plásticas com a natureza. Introd., trad. e notas de Fernando R. de Moraes Barros. BH: Ed. UFMG, 2011, p.21.

274 "Wo der Mensch schmückt, hebt er nur mit mehr oder weniger bewusstem Thun eine Naturgesetzlichkeit an dem Gegenstande, den er ziert, deutlicher hervor'. SEMPER, Gottfried. Über die formelle Gesetzmassigkeit des Schmucks und dessen Bedeutung als Kunstsymbol. Zürich: Meyer \& Zeller, 1856, p. 102 .
} 
de arquitetura do romano Vitrúvio: simetria, ${ }^{275}$ da qual deriva a euritmia ${ }^{276}$ - uma espécie de simetria fechada e que, por isto, proporciona um enquadramento ou moldura $^{277}$, , proporcionalidade ${ }^{278}$ e direção ${ }^{279}$. Tem-se como exemplo de adornos destes tipos os brincos, que reforçam a simetria, os colares, relacionados à euritmia e também à proporcionalidade, e adornos usados na cabeça que possam reforçar a direção frontal.

Essas são para Semper leis formais abstratas, presentes na conformação de todo fenômeno natural, que o homem reproduzia por meio dos artefatos por ele fabricados e reforçava mediante a ação de adornar algo. Mas, associadas a essas abstrações estariam forças que agem no mundo real dos fenômenos, acredita o autor. ${ }^{280} \mathrm{Em}$ virtude disso, Semper associa esses princípios formais aos três eixos de coordenadas geométricas espaciais nos quais agiria para ele a mecânica do universo. Logo, no eixo vertical (proporcionalidade) agem a força da gravidade e, oposta a ela, a que Semper chama de força vital, quer dizer, "aquela que com independência da vontade produz o crescimento orgânico da configuração, de baixo para cima". ${ }^{281}$ No eixo horizontal que se projeta perpendicularmente à frente do vertical (direção) agem a força da vontade e, no sentido oposto, a inércia, que é resultado do meio, mas atua no fenômeno. E por último, no outro eixo horizontal, no sentido direita-esquerda (simetria) não necessariamente atuam forças, mas o que há é a distribuição das massas. ${ }^{282}$

Como se observa, apesar de Semper retomar a tradicional associação entre Ornamento e ordem cósmica, ele opera a partir da epistemologia científica de sua época. Segundo Spyros Papapetrus, em Semper os adornos atendem a uma ordenação ao

diagramar e conotar simbolicamente relações analógicas com o cosmos. Mas, se no antigo tais correspondências cosmológicas seriam mediadas pela imaginação antropomórfica e zoomórfica, [...] então no universo pós-newtoniano de Semper as mesmas

\footnotetext{
275 Symmetrie, para Semper, implica o espelhamento bilateral a partir de um eixo central, concepção possivelmente proveniente da interpretação que Claude Perrault fez do antigo tratado De Architectura.

${ }^{276}$ Semper emprega Eurhythmie em uma acepção bem diversa da de Vitrúvio, no sentido literal de bom ritmo, enquanto uma sequência fechada, ordenada e sucessiva.

277“...euritmia é simetria fechada...” [...ist Eurhythmie geschlossene Symmetrie...] e por isto seu fundamento é o fechamento, a moldura ou enquadramento [Rahmen]. Der Stil, vol. I, op.cit., p.XXVII.

278 Proportionalität seria a relação entre as partes verticais de um fenômeno.

279 Richtung, o princípio da direção, para Semper, implica o realce das propriedades de movimento e direção dos corpos.

280 SEMPER, Über die formelle Gesetzmassigkeit des Schmucks, op.cit.

281 “...die unabhängig vom Willen, das organische Wachstum der Gestaltung von unten nach oben vertikal aufwärts hervorbringt”. Ibidem, p.118.

282 Id. Ibid.
} 
analogias cósmicas seriam convertidas em eixos geométricos que suportam a mecânica celestial do universo. ${ }^{283}$

No entanto, tais leis não são tão claras para o primitivo, segundo Semper. Como explícito em citação anterior, este indivíduo habita um universo "cuja lei o homem pressente, que ele gostaria de compreender, mas nunca decifra, que somente toca-o em poucos acordes fragmentários...". 284 O teórico constata esse pouco esclarecimento das leis mediante a observação dos tipos de adornos das tribos primitivas estudadas então pela Antropologia. Muitos destes artefatos, ao invés de embelezarem, eram usados para deformar partes do corpo, como brincos nas orelhas e colares no pescoço, ou para esconder partes corporais inteiras e também amedrontar, como, por exemplo, as máscaras ritualísticas: ${ }^{285}$

as primeiras tentativas de enriquecer a constituição natural do homem por meio de agregados artificiais apontavam mais a amedrontar do que a destacar o prazeroso da figura, mas mesmo nessa negação da aparência normal há uma difusa intuição e reconhecimento de sua legalidade. [...] também o esforço de mostrar imunidade heroica contra dores corporais deu o motivo para desfigurar e mutilar o corpo ou partes do corpo com meios artificiais, mais do que adorná-lo. 286

Certamente, com o avanço das civilizações - e na historiografia que Semper concebe ele refere-se de um modo geral às grandes civilizações da Antiguidade, principalmente a egípcia, assíria e grega - o olhar do autor que, assim como o Klemm, é de certo modo evolutivo, observa um progresso na percepção e representação da beleza, uma vez que acredita que as leis passam a ser melhor seguidas e a dependência da beleza do conteúdo religioso muitas vezes a ser reduzida. ${ }^{287}$

\footnotetext{
283 "...to diagram and symbolically connote analogical relations with the cosmos. But if in the antique such cosmological correspondences would be mediated by anthropomorphic and zoomorphic imagination [...] then, in Semper's pos-newtonian universe the same cosmic analogies would be converted into geometric axes supporting the celestial mechanics of the universe". PAPAPETRUS, Spyros. World ornament. The legacy of Gottfried Semper's 1856 lecture on adornment. In: PELLIZZI, Francesco (ed.). RES: Anthropology and Aesthetics, New York, London: Cambridge University Press, 2010, v.57/58, p.310.

284 Conferir nota 256.

${ }^{285}$ Ele cita as máscaras de animais usadas pelos índios das ilhas da Oceania para as danças de guerra, também os botocudos brasileiros, que perfuram lábios e outras partes do corpo. Cf. SEMPER, Über die formelle Gesetzmassigkeit des Schmucks..., op.cit.

286 "Die ersten Versuche freilich, den natürlichen Wuchs des Menschen durch künstliche Zuthaten zu bereichern, zielen mehr darauf ab, zu schrecken als das Wohlgefallen der Erscheinung zu erhöhen, doch selbst in diesem Verleugnen des Normalen der Erscheinung liegt ein dunkles Ahnen und Anerkennen seiner Gesetzlichkeit. [...] auch gab das Bestreben, heroische Abhärtung gegen körperliche Schmerzen zu zeigen, die Veranlassung, den Körper other Theile des Körpers durch künstliche Mittel mehr zu entstellen und zu verstümmeln, als zu schmücken". Id. Ibid., p.102.

287"As abomináveis mascaras de animais dos guerreiros índios aparecem em uma configuração mais refinada entre os egípcios [...]. A máscara se tornou um símbolo muito antigo do ocultamento, do secreto e
} 
Esse viés religioso, segundo o autor, mostra-se presente já no que ele compreendia como sendo possivelmente o mais primordial artefato têxtil: o nó

(figuras 7 e 8), "talvez o mais antigo símbolo técnico [...], a expressão das mais antigas ideias cosmogônicas", ${ }^{288}$ que serve como "meio de ligação das terminações de dois fios". ${ }^{289}$ O nó exemplifica o sentido mais essencial de todo artefato têxtil, o de unir, juntar, e, na compreensão de Semper, ele está presente no simbolismo religioso de diversos povos:

\begin{abstract}
em todos sistemas teogônicos e cosmogônicos ele é o símbolo universal do encadeamento primordial das coisas, da necessidade - que é mais antiga, como o mundo e os deuses, que encaixa tudo e dispõe de tudo [...] Nós o encontramos em profusa proliferação e quase sempre o mesmo, ou pelo menos, em essência muito semelhante, no começo e no fim de toda grande existência social; também as próprias formas, que resultaram de sua interpretação refinada, são encontradas em notáveis semelhanças por povos que parecem não ter a menor relação ou parentesco um com o outro. ${ }^{290}$
\end{abstract}

\footnotetext{
por sua vez aterrador. Frequentemente em uma posterior forma artística não permanece da máscara mais do que é característico do animal, como os chifres do touro como adorno da mitra do soberano assírio ou os chifres de carneiro como penteado do rei egípcio, que Alexandre, como filho de Zeus Amon, também adotou para si ". Tradução de "So treten die abscheulichen Thiermasken der indianischen Krieger in feinerer Ausbildung [...] Es wurde die Maske ein sehr frühes Sinnbild der Verhüllung, des Geheimnissvollen und zugleich Schreckbaren. Oft bleibt in späterer Kunstform von der Maske nichts als das Charakteristikum des Thieres übrig; z.B. die Stierhörner als Schmuck der Mitra der assyrischen Herrscher, die Widderhörner als Kopfputz der ägyptischen Könige, die auch Alexander, als Sohn des Zeus Ammon, für sich adoptirte". Id.Ibid., p.102.

288"Der Knoten ist vielleicht das älteste technische Symbol [...], der Ausdruck für die frühesten kosmogonischen Ideen...". SEMPER, Der Stil, v.l, op.cit., p.180. Em seus escritos, como se verá, Semper explora a ideia de símbolo. Consoante demonstra Todorov, desde o final dos setecentos, a ideia de símbolo vinha sendo rediscutida por estudiosos da literatura e das artes visuais e envolvia novos modos de pensar a significação. No entanto, ainda segundo este autor, as teorias estéticas que se formam a partir de então ainda mantém certo compromisso com o ponto de vista clássico, a partir, sobretudo, da ideia de imitação da natureza, a qual, em sua relação com a significação, vê implicada a problemática dos símbolos. TODOROV, Tzvetan. Teorias do Símbolo. Tradução Enid A. Dobránszky. Campinas, SP: Papirus, 1996. Na teorização dos símbolos elaborada na época da Estética nota-se a emergência de uma reflexão da linguagem que é abordada não mais como meio para a representação, mas como uma finalidade em si, condição que se observa também nos escritos de Semper. Para uma discussão mais aprofundada sobre a questão do símbolo na época de Goethe, por exemplo, conferir: ROSA, Elis Piera. O símbolo e a alegoria nos textos teóricos de Goethe (de 1772 a 1798). 2012. 161f. Dissertação (Mestrado em estudos Literários apresentado para a Faculdade de Ciências e Letras da Universidade Estadual Paulista Júlio de Mesquita Filho -UNESP), Araraquara, 2012.

289“... als Verknüpfungsmittel zweier Fadenenden”. SEMPER, Der Stil, vol.I, op.cit.,p.180.

290" Es ist in allen theogonischen und kosmogonischen Systemen das gemeinsam gültige Symbol der Urverkettung der Dinge, der Nothwendigkeit - die älter ist, als die Welt und die Götter, die Alles fügt und über Alles verfügt.[...] Wir begegnen ihm daher in vollstem Wucher und zwar fast immer gleich oder doch im Wesentlichen sehr nahe verwandt, am Beginne und am Schlusse jeder grossen Gesellschaftsexistenz; auch selbst Formen, die aus seiner veredelten Auffassung hervorgegangen sind, finden sich in auffallendster Aehnlichkeit bei Völkern, die nicht die geringste Gemeinschaft oder Stammverwandtschaft mit einander zu haben scheinen..... Id.Ibid., p.83.
} 

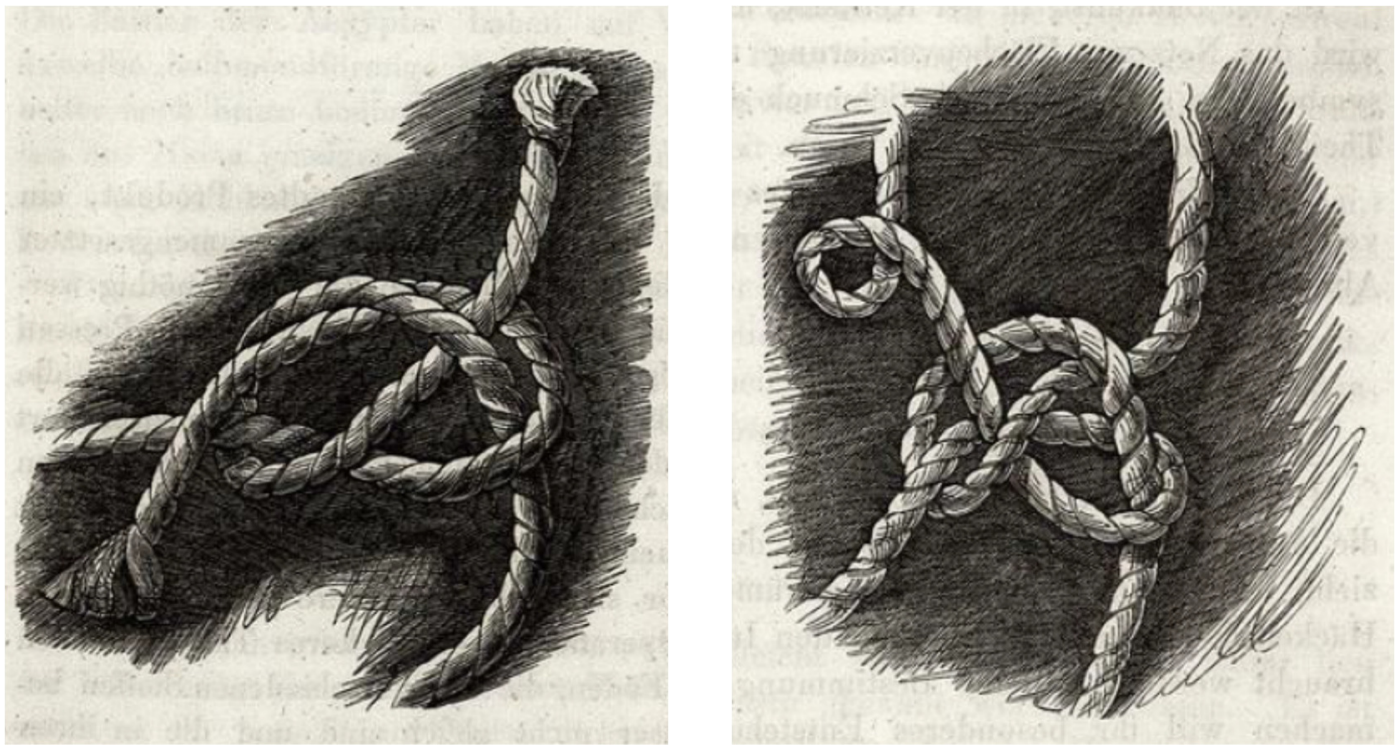

Figuras 7 e 8 - Exemplos de nó, desenhos de Semper. Fonte: SEMPER, Der Stil, vol.I, 1860.

Um exemplo deste simbolismo religioso seria o caduceu de Hermes (figura 9), além do propósito essencial de unir partes, ele representa o símbolo do comércio, reforçado pelos motivos iconográficos tradicionais das asas:

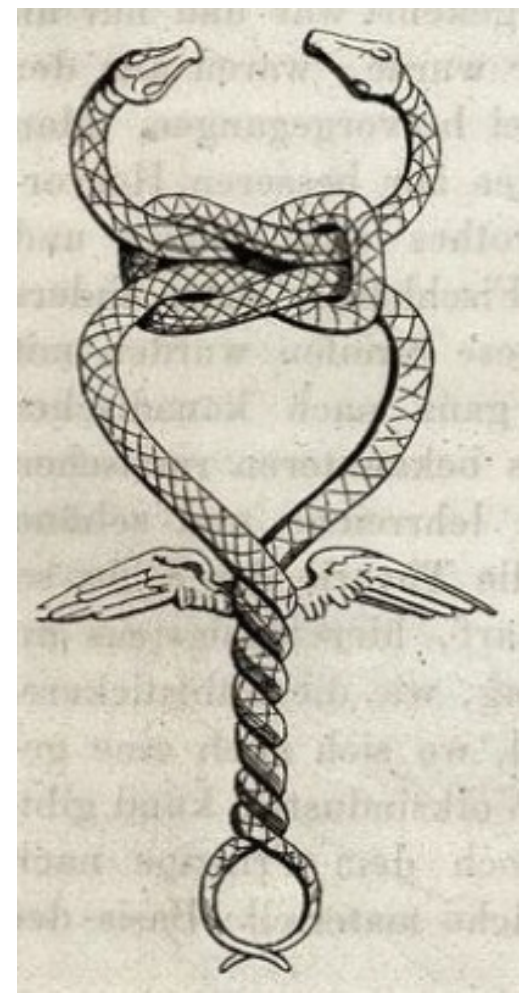

Figura 9 - llustração do Caduceu de Hermes, desenho de Semper. Fonte: SEMPER, Der Stil, vol.I, 1860. 
$\mathrm{Na}$ concepção evolutiva do teórico hamburguês, do nó surgiriam outros artefatos com trabalhos e materiais mais complexos, como laços, trançados e, em seguida, superfícies planimétricas em trama (figuras 10 a 12). Todos estes entrelaçados eram fabricados inicialmente com ramos e fibras vegetais, e Semper acredita que a diversidade natural de cores e nuances cromáticas destes materiais teria sugerido ao primitivo trabalhá-los em uma disposição alternada, em combinações diferenciadas, o que teria levado ao surgimento do padrão decorativo. ${ }^{291}$ Nota-se neste discurso que a cor, para Semper, está na origem da fábrica artística, pois foi ela que motivou a percepção e reprodução do padrão. ${ }^{292}$ Mas o domínio de tais superfícies planimétricas decoradas, antes de serem pensadas para o vestuário próprio, atendiam a uma necessidade ordenadora fundamental: a construção de um abrigo, de uma casa.

\footnotetext{
291 "....as diversidades de cores naturais dos caules logo motivaram a sua utilização segundo uma ordem alternada e assim surgiu o padrão decorativo". Tradução de "...die Verschiedenheiten der natürlichen Farben der Halme veranlassten bald ihre Benützung nach abwechselnder Ordnung und so entstand das Muster". Id.Ibid., p.228, grifo do autor. Essa conclusão de Semper teve fortuna na história da arte e gerou repercussão em meios especializados devido a sua suposta sugestão materialista da origem do padrão decorativo geométrico. Exemplo disto foi o fato de ter sido um dos pontos de contenda entre o historiador da arte Alois Riegl e as interpretações dos escritos de Semper por seus seguidores. Em seu Stilfragen, Riegl procurou desconstruir a interpretação, suscitada pelos escritos de Semper no Der Stil, de que o estilo geométrico, ou seja, os padrões geométricos da ornamentação teriam surgido espontaneamente do processo técnico de entrelaçamento. Conforme Riegl, estava claro que Semper "não estava desconsiderando a intervenção de fator não materialista. [...], não foi o mero acaso que trouxe o primeiro padrão ao mundo; alguém fez uma escolha consciente, preparada [...]. Consequentemente, aos seres humanos é concedida explicitamente uma contribuição criativa, artística a todo o processo". Tradução de "...he was discounting the intervention of a nonmaterialist factor. [...] it was not pure chance that brought the first pattern into the world; someone had made a conscious, "prompted" choice... Consequently, human beings are explicitly granted a creative, artistic contribution to the whole process". RIEGL, Alois. Problems of style: foundations for a history of ornament. Trans. Evelyn Kain. Princeton: Princeton University Press, 1992, p.24.

292 Semper sustenta que os indivíduos tinham naturalmente em si um prazer na cor, que teria surgido antes do prazer na forma e ao qual não correspondia nenhuma necessidade material: "O prazer na cor desenvolveu-se anteriormente ao prazer na forma; mesmo o inseto mais inferiormente organizado alegrase com o brilho do sol, com a chama, e com as crianças da luz, as flores brilhantes do campo". Tradução de "Die Lust an der Farbe ist früher entwickelt als die Lust an der Form; selbst das niedrig organisirte Insekt freut sich am Sonnenglanz, an der Flamme und an den Kindern des Lichts den glänzenden Blumen des Feldes". SEMPER, Der Stil, vol. I, op.cit., p.202. Ele ainda suspeita que a pintura ou o tingimento de peles, de animais ou da própria pele, possa ter sido uma das primeiras manifestações desse prazer na cor, o que também pode ter levado a tatuagem a ter sido a primeira das artes decorativas.
} 


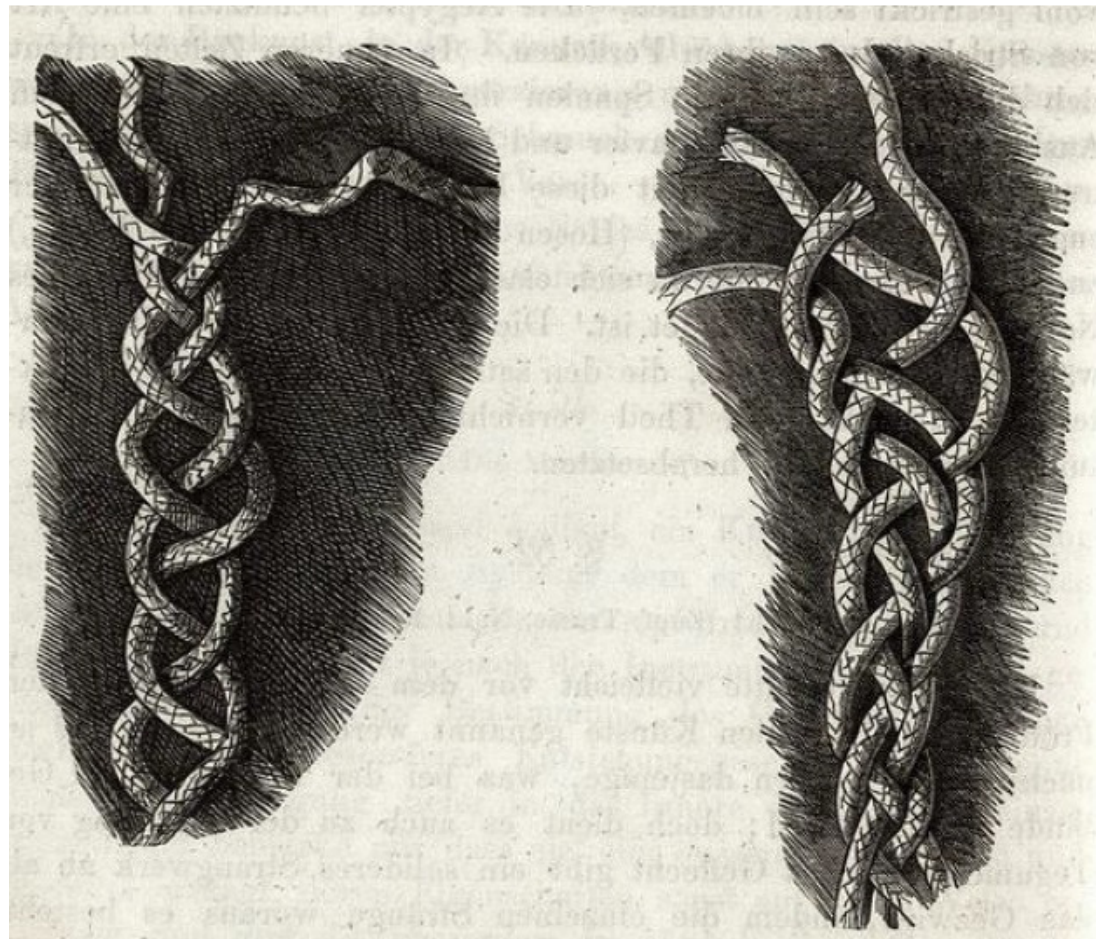

Figura 10 - Exemplos de trançados, à esquerda, um exemplo de três fios e à direita, um de quatro. Desenhos de Semper. Fonte: SEMPER, Der Stil, vol.I, 1860
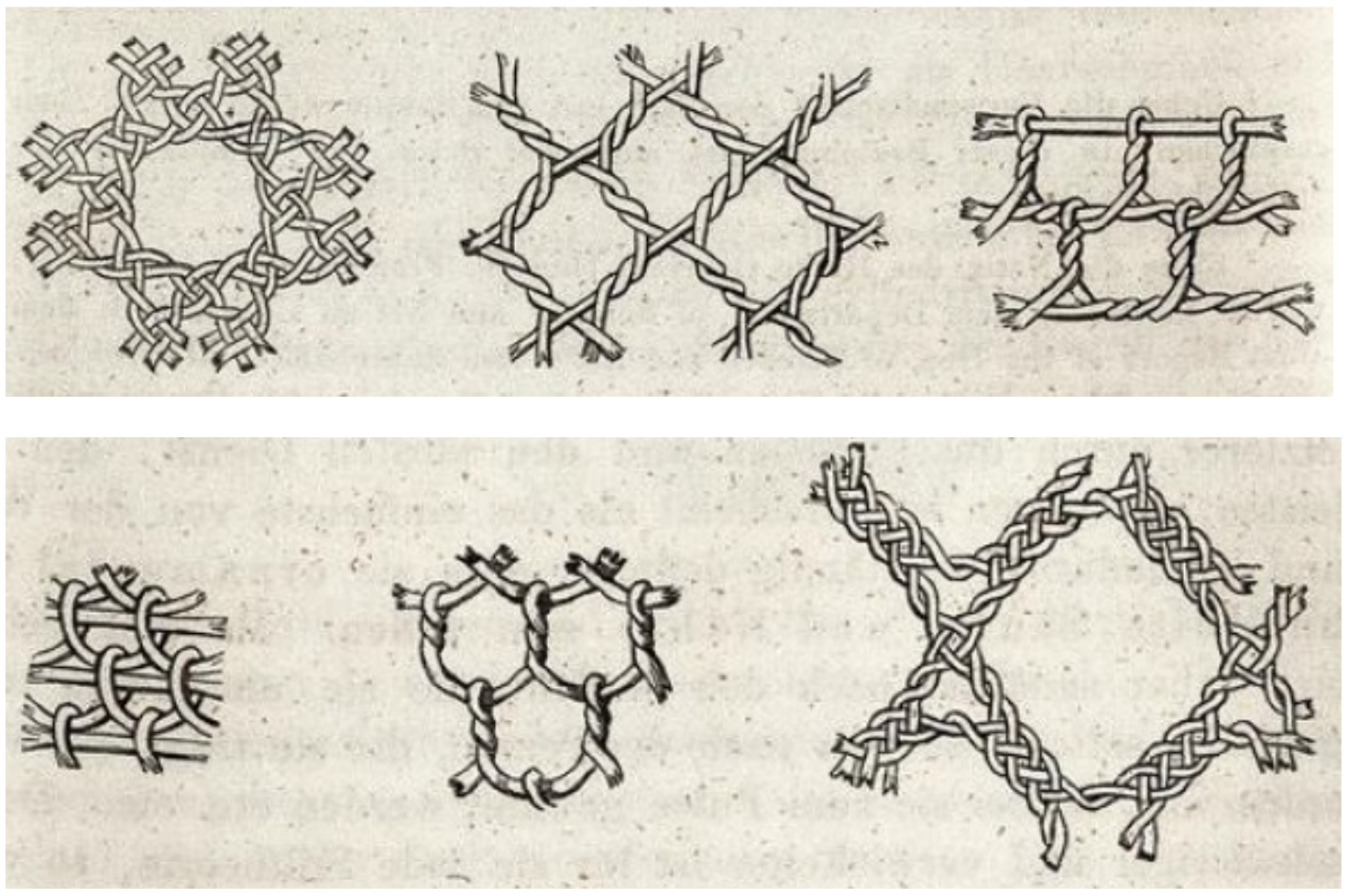

Figuras 11 e 12 - Exemplos de trabalhos em trama, cuja variedade permite observar a possibilidade de ricas composições. Desenhos de Semper. Fonte: SEMPER, Der Stil, vol.I, 1860. 


\subsection{A divisória decorada e a cabana primitiva: a vida coletiva em família}

$\mathrm{Na}$ sua forma primitiva, o ritual, conforme compreendido por Semper, girava em torno de um elemento de fundamental importância: o fogo. Segundo o teórico, este era o centro sagrado em torno do qual a vida coletiva se constituía:

ao redor do fogo os primeiros grupos se reuniram; nele as primeiras alianças se teceram; nele os primeiros rudes conceitos religiosos foram formulados nos usos culturais de um culto. Por todas as fases de desenvolvimento da sociedade o fogo formou o ponto sagrado ao redor do qual o todo tomava ordem e forma. ${ }^{293}$

Desde tempos imemoriais, o local em que a fogueira era acesa era lugar de adoração solene, pois em muitos agrupamentos os líderes ou chefes tribais primitivos eram enterrados próximo à chama sagrada, assim como sacrifícios eram ali realizados em devoção a eles. ${ }^{294}$ Daí o fato de em torno dele terem surgido as primeiras alianças e conceitos religiosos, que contribuíram na constituição da vida em comum; o fogo, nesse sentido, tinha para Semper um propósito moral, e também político.

A importância desse elemento, deduz o teórico hamburguês, teria levado os grupos primitivos a uma preocupação em proteger sua flâmula:

proteção da lareira. Não há necessidade de provar em detalhes que a proteção da lareira contra os rigores do tempo, bem como contra ataques de animais selvagens e inimigos foi a principal razão de separar algum espaço do mundo exterior. ${ }^{295}$

O impulso inicial dessa necessária proteção foi o cercamento do fogo, com a fabricação de divisórias verticais, próximas à escala humana, que pudessem ao menos proteger o homem e a chama do vento e dos ataques externos. No discurso de Semper, aí se encontra o "mais primordial

\footnotetext{
293“ Um den Herd versammelten sich die ersten Gruppen, an ihm knüpften sich die ersten Bündnisse, an ihm wurden die ersten rohen Religionsbegriffe zu Culturgebräuchen formulirt. Durch alle Entwicklungsphasen der Gesellschaft bildet er den heiligen Brennpunkt, um den sich das Ganze ordnet und gestaltet'. SEMPER, Die vier Elemente.., op.cit., p.55.

294“...ela [a lareira] era o lugar sagrado para adoração solene. O sepulcro do ancestral era localizado prórimo ao fogo. Este ainda é o costume com os índios da Colômbia. Alguns [...] colocam os túmulos de seus chefes no centro de suas cabanas..." Tradução de: "...it [the hearth] was the sacred place for solemn worship. The ancestors' grave was close to the heart. This is still the custom with the Indians of Colombia. Some [...] place the tombs of their chiefs in the center of their huts..." SEMPER, The basic elements of architecture. (Introduction to "Comparative Building Theory"), op.cit., p.198.

295 "Protection of the hearth. There is no need to prove in detail that the protection of the hearth against the rigors of the weather as well as against attacks by wild animals and hostile men wasthe primary reason for setting apart some space from the surrounding world'. Id.lbid., p.199.
} 
encerramento vertical do espaço", 296 que seria o ponto inicial para a constituição do espaço habitado na forma de um abrigo; e esse encerramento constitui, podese dizer, em fase embrionária, a "ideia arquitetônica original". ${ }^{297}$ Para o teórico, o fogo é a motivação principal da construção de um abrigo e, consequentemente, do surgimento da Arquitetura.

Esse cercamento originário que protege o fogo e que, pode-se afirmar, delimita-o como um centro - o centro sagrado da casa como sendo a reprodução em miniatura do centro do mundo ${ }^{298}$-, é fabricado a partir da habilidade adquirida com o procedimento do trançar, entrelaçar, ou seja, a divisória consiste em uma forma planimétrica resultante da linearidade dos materiais utilizados. ${ }^{299}$ E Semper sustenta que, do trabalho de entrelaçamento de fibras naturais houve um salto lógico e natural para meios artificiais de fabricação, como a tecelagem e o tingimento, ${ }^{300}$ o que levou à consequente substituição da cerca por tapetes coloridos, usados também como divisórias, pisos e forros de tetos: "logo superou-se estes materiais naturais da arte mediante procedimentos artificiais de preparação do material, o tingimento e a tecelagem de tapetes coloridos foram inventados para vestir paredes, cobrir pisos e forrar tetos." 301 Também com a tecelagem veio em seguida o bordado, que permitiu a criação de padrões figurativos curvilíneos, como figuras de animais e plantas.

E, como observado, para Semper, o trabalho com trançados e tapetes para a habitação pode inclusive ter precedido a elaboração de vestimentas têxteis próprias, o que sugere que a cultura enquanto fenômeno coletivo, distinto do estado de natureza, manifestou-se antes na casa do que no vestuário. $O$ autor sustenta que

há tribos cuja selvageria parece ser a mais primitiva, que não conhecem nenhum vestuário; das quais, entretanto, não é

\footnotetext{
296“...den ursprünglichsten vertikalen räumlichen Abschluss”. SEMPER, Der Stil, vol. I, op.cit., p.227. 297“... die ursprüngliche architektonische Idee..." Id.Ibid., p.228.

298 Nota-se no raciocínio de Semper aquilo que colocou Mircea Eliade sobre a casa primitiva. Consoante Eliade, os grupos arcaicos desde muito cedo assimilaram a relação entre corpo humano, casa e cosmos, na medida em que os dois primeiros seriam uma espécie de reprodução do segundo, ou seja, um microcosmo. ELIADE, Mito e Realidade, op.cit., p.141.

299 As superfícies têxteis serviam também para outros propósitos, como para capacho de pisos ou forro para tetos, uma vez que ambos, de certo modo, também forram um espaço. Eles só não se relacionam diretamente com o corpo humano ereto, marca definidora do espaço para o teórico.

300 Consoante Joseph Rykwert, observa-se neste discurso "a passagem sutil, gradual, do dispositivo natural ao artifício". RYKWERT, A casa de Adão no paraíso..., op.cit., p.25.

301 "Bald überbot man diese natürlichen Hülfsmittel der Kunst durch künstliche Vorbereitung des Stoffs, das Färben und die Wirkerei der bunten Teppiche zu Wandbekleidungen, Fussdecken und Schirmdächern wurde erfunden". SEMPER, Der Stil, v.l, op.cit, , p.228.
} 
desconhecida a utilização de peles e mesmo possuem uma indústria mais ou menos desenvolvida de fiação, trançamento e tecelagem, que empregam para a fundação e a proteção de seus acampamentos. ${ }^{302}$

Assim, em Semper, "os começos da construção coincidem com os começos dos têxteis", ${ }^{303}$ e se as origens da fábrica artística se dão com o adorno têxtil - pois ao mesmo tempo que o homem fabrica algo ele também embeleza - o Ornamento, na forma do padrão decorativo têxtil, empregado agora em coloridos tapetes, é também origem da construção.

Essa construção primordial concebida por Semper é constituída por quatro elementos; além do fogo e da divisória vertical, tem-se uma plataforma elevada e também um telhado de duas águas que forma uma unidade junto à estrutura de colunas que o suporta. Todos eles, além de atender a necessidades materiais, também são fruto do instinto artístico, e por isso, evidenciam um simbolismo ordenador: o fogo, como observado, além de aquecer, viabilizar o preparo alimentos e proteger, reúne e centraliza os indivíduos, é, pois, "símbolo da civilização e da religião";304 a divisória, além de proteger contra o vento e ataques de inimigos, delimita, envolve um espaço e marca o centro; a plataforma elevada não somente protege contra possíveis inundações e contra a umidade do solo, mas também eleva, e, como um pedestal, separa a edificação da natureza e da vida mundana ao redor, pois, "ao elevar uma edificação ou um objeto em um pedestal com fomato de altar ou em uma base, isto significa ser ele sagrado"; 305 e por fim o telhado de duas águas que, além de proteger contra a chuva, é "símbolo universal para a divindade e atributo de santuários e habitações divinas". ${ }^{306}$ Assim como o adorno corporal, também esses elementos, como expressões artísticas, seguem as leis cósmicas; por exemplo, a divisória, ao envolver e destacar o fogo, atende à euritmia - cria um pequeno mundo fechado em si mesmo; o telhado de duas águas, por sua vez, ao cair lateralmente e apontar para o alto, evidencia a simetria, assim como a direcionalidade.

\footnotetext{
302“Es gibt Stämme deren Wildheit eine ursprünglichste zu sein scheint, die keinerlei Bekleidung kennen, denen aber die Benützung von Fellen und sogar eine mehr oder minder entwickelte Industrie des Spinnens, Flechtens und Webens, die sie zur Einrichtung und Sicherung ihres Lagers anwenden, nicht unbekannt ist". Ibid.,p.227.

303“...die Anfänge des Bauens mit den Anfängen der Textilien zusammenfallen”. Ibid., p.227.

304 "It [the fireplace] is the symbol of civilization and religion...". SEMPER, London lecture of autumn 1854: On architectural symbols, op.cit., p.66.

305 "By elevating a building or an object on an altar-formed pedestal or basement it signifies (it) to be sacred". Id.Ibid., p.66.

306 "the universal symbol for divinity and the attribute of sanctuaries, and divine dwellings". Id.Ibid., p.66.
} 
Destes valores simbólicos, o do fogo e da divisória seriam os principais e assumem maior importância no discurso de Semper, pois, como se deduz, referem-se direta e essencialmente ao homem e a valores humanos, um porque reúne e favorece a vida coletiva, a outra porque, em estreita relação com 0 primeiro, cria o espaço, não somente o espaço de referencia antropométrica, mas sobretudo porque promove o espaço habitado. Ou seja, essa ideia espacial evidenciada pela divisória vertical, na concepção de Semper, não se refere simplesmente à definição de um espaço geométrico, encerrado, um "dentro" em relação a um "fora", mas sim à configuração do lar, na medida em que a divisória faz separar a vida interna da vida externa. ${ }^{307}$ Isto porque, na vida doméstica, é a decoração, os efeitos sensórios da materialidade de sua superfície colorida e de seus padrões decorativos simbólicos que definem a casa, manifestam a ideia de lugar ocupado, onde ocorre a experiência da vida em comum.

Como coloca Mark Wigley:

para Semper, a construção originou-se com o uso de materiais trançados para definir o espaço social, especificamente, o espaço da domesticidade. Mas os têxteis não eram simplesmente colocados dentro de um espaço para definir certa interioridade. Eles não eram simplesmente organizados na paisagem para dividir um pequeno espaço que poderia ser ocupado por uma determinada família. Mais do que isso, eles eram a própria produção do espaço, lançando a própria ideia de ocupação [...]. A moradia, deste modo, é um efeito da decoração. [...] Espaço, casa, e estrutura social surgem com o Ornamento. O interior não é definido por um invólucro contínuo de paredes, mas pelas dobras, torções e desvios em uma superfície frequentemente descontínua. ${ }^{308}$

Antes de elementos materiais, construtivos, os quatro elementos pensados por Semper pressupõem ideias criadoras ou motivos originários que, reificados nos quatro tipos citados, constituiriam uma cabana primitiva. ${ }^{309} \mathrm{~A}$ cada

\footnotetext{
307“....assim é certo que a utilização de um rude trançado provém da cerca, como um meio de estabelecer o lar, de separar a vida interna da vida externa....". Tradução de "...so bleibt gewiss dass die Benützung grober Gewebe, von Pferch ausgehend, als ein Mittel das 'home', das Innenleben, von dem Aussenleben zu trennen...". SEMPER, Der Stil, v.l, op.cit, p.228.

308"For Semper, building originated with the use of woven fabrics to define social space, specifically, the space of domesticity. But the textiles were not simply placed within space to define a certain interiority. They were not simply arranged on the landscape to divide off a small space that could be occupied by a particular family. Rather, they were the production of space itself, launching the very idea of occupation. [...] Housing is an effect of decoration then. [...] Space, house and social structure arrive with ornament. The interior is not defined by a continuous enclosure of walls, but by the folds, twists and turns in an often discontinuous ornamental surface". WIGLEY, Mark. White walls, designer dresses, op.cit., p.11.

309 Em grande parte de seus escritos, Semper emprega mais ou menos indistintamente "motivos", "elementos" e "idéias" para se referir a estas ideias primordiais de criação. Mallgrave considera o termo
} 
motivo originário Semper associa um ofício e um material mais apropriados para o propósito construtivo e simbólico: ao fogo estava associada a cerâmica e o trabalho com argila; à divisória vertical, como observado, fibras têxteis e o trabalho de trançados ou tecelagem; à plataforma estava associada a pedra e a estereotomia ou trabalho com alvenaria de pedras; ao telhado vinculava-se a madeira e a carpintaria.

À primeira vista, a associação da origem da construção a uma cabana primitiva sugere um vínculo à Tradição Clássica da Arquitetura, que reconhecia a especulação das origens conforme exposta na tratadística vitruviana. De fato, o discurso de Semper sobre os primórdios guarda certa afinidade com o do estudioso romano. Também em Vitrúvio o fogo tem um papel fundamental no surgimento da vida em comum e das instituições culturais humanas. Se Semper menciona a religião e as alianças políticas como resultado do agrupamento proporcionado pelo calor do fogo, no De Architectura é apontada a linguagem que, ao facilitar a comunicação, permitiu ao homem se organizar e constituir sua vida coletiva e com ela, construir abrigos para si. ${ }^{310} \mathrm{Em}$ ambos, o fogo foi o responsável pela condução a uma vida civilizada.

No entanto, apesar desta proximidade, Semper rejeitou implacavelmente a cabana de Vitrúvio, bem como as interpretações posteriores dela, como as de Laugier e Quatremère de Quincy. ${ }^{311}$ Para o autor do Der Stil, uma cabana de

elementos [Elemente] como "enganoso" [misleading], pois dá a entender algo material ou formal, fato que em sua origem não era. Ao contrário, deve-se percebê-lo mais na acepção de um conceito, uma idéia, uma força, associada a operações técnicas das artes aplicadas. Conferir Introduction. In: SEMPER, Gottfried. The four elements of architecture and other writings. Trans. Harry Francis Malgrave and Wolfgang Herrmann. Cambridge: Cambridge University Press, 1989, p.24. Em uma conferência de sua época londrina, Semper distinguiu entre Tipo e Motivo. Segundo ele, as Ideias Elementares são "o que o artista designa os Motivos das coisas"; os Tipos são "as formas primeiras, nas quais estas Ideias fundamentais foram vestidas". Tradução conforme o original em inglês “...the elementary ldeas or what the Artist calls the Motives of the things..." e "...the early forms, in which these fundamental Ideas have been clothed". SEMPER, London Lecture of November 11, 1853, op.cit., p.11.

310 "...árvores agitadas e oprimidas pelas tempestades e pelos ventos, friccionando repetidamente entre si os ramos, provocaram o fogo; [...] aproximando-se e dando conta da grande vantagem para os corpos em estar junto do calor do corpo, ajuntando lenha e mantendo-o aceso, chamaram outros, e, dando-o a entender por sinais, descobriram o proveito que daí poderiam retirar. Como naquele encontro de homens se produziam sons que eram alimentados pelo sopro, foram-se estabelecendo vocábulos à medida que iam surgindo no uso cotidiano [...] Tendo, pois, assim nascido, devido à descoberta do fogo, o encontro, a reunião e a sociedade entre os homens, reunindo-se muitos no mesmo lugar e tendo naturalmente a vantagem de andar ereto e não curvado como o restante dos seres vivos, para olhar a magnificência do firmamento e dos astros, assim como poder, com as mãos e os dedos, trabalhar facilmente tudo aquilo que quisessem, começaram uns nesse ajuntamento a construir habitações...". VITRÚVIO, Tratado de arquitetura, op.cit., livro segundo, capítulo I, pp.112-3.

311 A visão idealista neoclássica de Laugier era fundamentada, em grande medida, na autoridade dos antigos, a qual de certo modo, considerando a difusão dos diversos revivalismos no século XIX e o sentido da história vigente, já tinha perdido parte de sua legitimidade como cânone a ser absoluta e fielmente seguido. Para Colquhoun, "a visão historicista discutia a epistemologia da qual dependia essa visão de Arquitetura e gerou uma interpretação totalmente diferente do Ideal". COLQUHOUN, Três tipos de 
madeira não era a origem do templo grego em pedra, tampouco a origem da Arquitetura, bem como não era um modelo fixo a ser seguido. A cabana pensada por Semper é resultado dos quatro motivos e não assume uma forma fixa. ${ }^{312}$ Segundo Sokratis Georgiadis, Semper "demoliu o protótipo da concepção clássica da Arquitetura, a cabana vitruviana, e colocou em seu lugar o conceito pluralista dos quatro elementos (fogo, cerca, telhado, plataforma) como tipos originários da Arquitetura". 313 Para Semper, a origem da Arquitetura está nos ofícios, particularmente no adorno decorativo, não em um modelo de cabana.

Ainda, diferentemente da Tradição, que conferiu grande importância à coluna, é à parede, ou melhor, ao fechamento, que Semper dirige sua atenção. Nesse sentido, ele difere substancialmente de Laugier, para quem a parede fazia parte dos elementos toleráveis de um rigorismo arquitetônico que observava a Arquitetura na essencialidade de coluna, entablamento e frontão. ${ }^{314}$ Semper destaca a divisória como móvel, maleável e policroma, definidora e responsável pela delimitação do espaço e um resultado da ornamentação.

A cabana também não é produto de alguma cultura específica, como a helênica. Semper não pretende afirmar uma origem, mas sim evidenciar as condições primordiais da criação de um abrigo pelos primitivos. ${ }^{315}$ Conforme atesta Herrmann:

\footnotetext{
historicismo, op.cit., p.25. Quanto a Quatremère de Quincy, Semper, sem citá-lo diretamente, critica sua teoria dos tipos: "...mencionou-se anteriormente escritores, os quais dedicam-se com pormenorizada minuciosidade às investigações sobre as origens da arte e daí a saber derivar a diversidade do modo de construir [...] entretanto, enquanto sua perspicácia reconhece a regra do modo tártaro-chinês de construção na linha do telhado da tenda nômade (apesar desta mesma forma ocorrer também nos gorros e sapatos destes povos), eles ignoram a influência mais geral e menor duvidosa que o tapete, em sua qualidade de parede, como meio de proteção vertical, exerceu no desenvolvimento de determiandas formas construtivas...". Tradução de "es wurde vorhin der Schriftsteller erwähnt, die mit umständlicher Gründlichkeit sich den Untersuchungen über die Anfänge der Kunst hingeben und daraus die Verschiedenheiten des Bauwesens abzuleiten wissen [...] Während aber ihr Scharfsinn in der Kettenlinie des Zeltdaches die Norm der tartarisch-chinesischen Bauweise erkennt (obschon dieselben Formen doch auch an den Mützen und Schuhen dieser Völker vorkommen), übersehen sie den allgemeineren und weniger zweifelhaften Einfluss, den der Teppich in seiner Eigenschaft als Wand, als vertikales Schutzmittel auf die Entfaltung gewisser Bauformen übte....". SEMPER, Die vier Elemente..., op.cit., p.56.

312 Para Bletter, os quatro motivos devem ser entendidos como "arquétipos" ou "conceitos arquetípicos". BLETTER, Rosemarie H. On Martin Fröhlich's Gottfried Semper. In: Oppositions, n.4, outubro de 1974, p.146-153.

313“...er demolierte den Prototyp klassizistischer Architekturauffassung, die vitruvianische Urhütte [...]. [An deren Stelle setzte er] das pluralistischere Konzept der vier Elemente (Herd, Umfriedigung, Dach, Erdaufwurf) als Urtypen der Architektur'. GEORGIADIS, Semper's schwierige Rückkehr aus dem zweiten Exil, op.cit., p.61.

314 Sobre a cabana primitiva de Laugier, conferir o primeiro capítulo. Conforme Rykwert, em Semper, "...os apoios, que mantêm o telhado sobre a lareira e que foram a principal preocupação dos teóricos, de Vitrúvio a Laugier, não apresentam nenhuma função como parte do arquétipo, qualquer que seja seu papel estrutural". RYKWERT, A coluna dançante, op.cit., p.36.

315 “...eu me vejo obrigado a retornar às condições primordiais da sociedade humana de modo a seguir naquilo que eu realmente intenciono explicar". Tradução de: “...sehe ich mich genöthigt, in die Urzustände
} 
obviamente, Semper tinha em mente cabanas reais, não estruturas ideais ou fictícias; ele examinou a influência destas cabanas no passado no surgimento e modificação das formas arquitetônicas. Ele não aceitou a função normativa do modelo fictício da cabana, que foi recomendado por muitos escritores da teoria clássica da Arquitetura, por exemplo, Laugier, como uma diretriz para a Arquitetura contemporânea. A cabana 'não é o modelo material e padrão para o templo', ele declarou no Der Stil... ${ }^{316}$

Sua cabana tem como referência aquela observada por ele na grande exposição industrial de 1851, uma cabana caribenha, de tribos da região da América Central (figura 13). Conforme apontou, nela "evidenciam-se todos os elementos da construção no seu modo mais original e não misturado..." 317

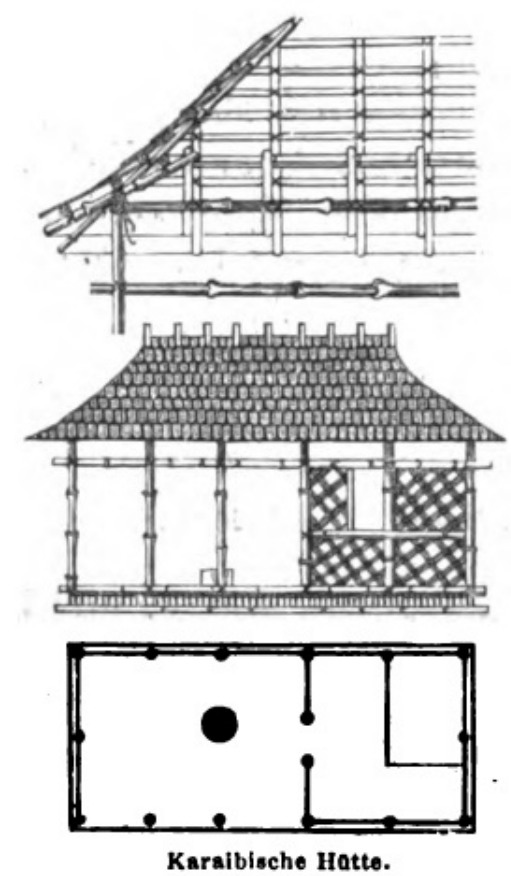

Figura 13 - Cabana observada na Exposição de Londres de 1851. Desenho de Semper. Fonte: SEMPER, Der Stil, vol.I, 1860.

\footnotetext{
der menschlichen Gesellschaft zurückzukehren, um zu dem zu kommen, was ich eigentlich darzulegen beabsichtige". SEMPER, Die vier Elemente..., op.cit., p.54.

316 "Obviously, Semper had in mind real huts, not ideal or fictitious structures; he examined the influence of these huts in the past on the rise and modification of architectural forms. He did not accept the normative function of the fictitious model of the hut, which had been commended by many writers on the classical theory of architecture, for instance Laugier, as a guideline for contemporary architecture. The hut 'is not the material model and pattern for the temple', he declared in Der Stil...". HERRMANN, Wolfgang. Semper's position on the primitive hut. In: Gottfried Semper. in search of architecture. Cambridge, Massachusetts: MIT press, 1984, pp.168-9, grifo de Semper reproduzido por Herrmann.

317 "An ihr treten alle Elemente der antiken Baukunst in höchst ursprünglicher Weise und unvermischt hervor...".SEMPER, Der Stil, v.II, op.cit., p.276.
} 
O teórico também tinha consciência de que a existência dos quatro motivos não era uma normativa. Como sua cabana era fruto das condições primitivas, não tendo, com isso, uma origem geográfica determinada e sendo dependente das características de clima e geografia, um ou outro motivo pode ter se desenvolvido mais ou menos, ou mesmo não ter sido explorado - com exceção do local do fogo e da envoltória -; o abrigo primitivo, em alguns locais, pode ter sido uma tenda, como em tribos nômades de caçadores e pastores.

Semper acredita que essa cabana primitiva levou ao surgimento do templo religioso, local onde a vida coletiva se expande na organização das instituições religiosas. Pois, se inicialmente os ritos ocorriam ao redor do fogo e este motivou a habitação, as práticas eram realizadas nas próprias habitações, e estas, com o desenvolvimento posterior das civilizações e da instituição religiosa, serviram como referência para a edificação sagrada: "o templo é a forma refinada e idealizada do mesmo motivo que fundamenta 0 desenvolvimento das habitações humanas". ${ }^{318}$ Refinado e idealizado porque, por ser a casa da divindade, o templo é mais rico nos seus materiais e mais exuberante na ornamentação, atributos que indicam o surgimento da Arquitetura, arte monumental para o autor.

\subsection{0 revestimento do corpo social: a arquitetura monumental}

Semper observa a condição humana como formada por oposições, por duas forças que se contrapõem: de um lado o esforço de independência, de destacar-se da existência telúrica e firmar sua individualização e de seu grupo familiar; e de outro a necessidade de constituir e centralizar sua vida social, provavelmente por questões de sobrevivência em meio aos perigos da existência:

ambas potências, a força centrífuga do senso de independência e o impulso oposto por subordinação, segundo a mais antiga concepção, estavam ativos, separados e ao lado um do outro, assim como também os maiores e mais antigos centros de cultura cresceram em imediata proximidade das localidades de

318 "... the temple is the refined and idealized form of the same motif that underlies the development of human dwellings". SEMPER, The basic elements of architecture. (Introduction to "Comparative Building Theory"), op.cit., p.197. 
estabelecimento de povos nômades. Esta oposição foi necessária também para a arte. ${ }^{319}$

Os grupos que se desenvolveram e conseguiram centralizar sua vida social organizaram um forte aparato institucional, o Estado. Foi o caso de algumas das grandes civilizações da Antiguidade - de acordo com a historiografia concebida por Semper -, em que Estado e religião eram os pilares fundamentais e centralizadores do corpo social coletivo. Com isso, nessas culturas, o templo era uma das principais instituições, e de acordo com Semper, ele surge das grandes festividades religiosas promovidas pelos poderes hieráticos e do Estado, como no Egito faraônico:

desta maneira surgiu o templo egípcio, dos motivos do mercado de peregrinação improvisado, os quais de certa forma, muito frequentemente, mesmo em tempos mais tardios, de modo muito semelhante, eram fixados a partir de estacas e cobertas de tendas, onde algum deus local, para o qual ainda nenhum templo fixo tivesse sido construído, chegou com a reputação de [ter] particulares poderes milagrosos e atraiu para sua festividade, em numerosas inesperadas incursões, camponeses peregrinos do Egito antigo. ${ }^{320}$

E essa estrutura precária de estacas e cobertas, móvel e improvisada, feita para glorificar a divindade, era profusamente ornamentada, mais do que as habitações. Recebia guirlandas, festões, máscaras, tapetes decorados, fitas esvoaçantes, partes de animais sacrificados, entre outros motivos os quais remetiam ao deus que se queria louvar e eram nela pendurados. Para Semper, esta estrutura decorada era o gérmen do verdadeiro monumento, da "verdadeira Arquitetura": 321

o aparato das festas, a armação improvisada, com todo seu fausto e acessórios, que mais precisamente marca a ocasião da comemoração e exalta, adorna e decora a glorificação da festa [...] é o motivo do monumento permanente". ${ }^{322}$

\footnotetext{
319 "Beide Potenzen, die Centrifugalkraft des Unabhängigkeitssinnes und die entgegengesetzte des Sinnes für Unterordnung waren nach ältester Vorstellung ausser und neben einander thätig wie denn auch die ältesten grossen Culturcentren in unmittelbarster Nähe der Sitze unstäter Nomadenvölker emporwuchsen. Man bedurfte dieses Gegensatzes auch für die Kunst'. SEMPER, Über Baustyle, op.cit., p.14.

320 "So ist der ägyptische Tempel aus dem Motive des improvisirten Wallfahrtsmarktes entstanden, der gewiss sehr häufig noch in später Zeit in ganz ähnlicher Weise aus Pfählen und Zeltdecken zusammengeschlagen wurde, wo irgend ein Lokalgott dem noch kein fester Tempel erbaut war in den Geruch besonderer Wunderthätigkeit kam und die wallfahrenden Fellahs Altägyptens in unerwartet zahlreichen Zügen zu seinem Feste herbeilockte". SEMPER, Der Stil, v.l, op.cit, p.230.

321 “...die eigentlich Baukunst". Ibidem, p.229.

322“Der Festapparatus, das improvisirte Gerüst, mit allem Gepränge und Beiwerke welches den Anlass der Feier näher bezeichnet und die Verherrlichung des Festes erhöht, geschmückt und ausgestattet [...] diess ist das Motiv des bleibenden Denkmals... "Ibidem, pp.229-30.
} 
Assim como o indivíduo se adorna e procura se destacar do estado de natureza, também as construções são adornadas e personificam valores de cada grupo social, valores expressos no monumento e reiterados nas comemorações. Deste modo, é no monumento que o fundamento moral e político do fogo encontra sua expressão máxima. Para Semper, a verdadeira Arquitetura é e deve ser monumental, ter uma forma pública exaltada na grandiosidade de edificações cujo propósito é "imortalizar comemorativamente algum ato solene, religioso, um acontecimento da história mundial, uma ação principal e do Estado". ${ }^{323}$

$E$, logicamente, a intenção de perenizar esses valores não seria alcançada com a estrutura improvisada e precária dos abrigos, feitos com materiais frágeis e mais facilmente perecíveis. $O$ abrigo móvel e débil da cabana primordial não possui o status de Arquitetura, trata-se, para Semper, de uma condição material e primitiva ou, como coloca Herrmann, do "estágio material da construção doméstica primitiva". ${ }^{324}$

De modo semelhante ao exposto em Vitrúvio, em Semper a Arquitetura como monumento só eterniza na memória social o que ela pereniza na carne, ou melhor, na pedra - principalmente. Na história da cultura, ela surge quando o homem passa a adotar materiais mais duráveis e resistentes. Por isso, de acordo com Semper, "a história geral da cultura da humanidade nos dá evidências do seguinte importante fato: a saber, que a Arquitetura não começa no mesmo ponto que a história da construção de casas e da engenharia". ${ }^{325} \mathrm{E}$, na historiografia observada na escrita de Semper, a Arquitetura é expressão das grandes civilizações da Antiguidade, como egípcios, fenícios, assírios, persas, gregos, romanos, entre outros que formaram estruturas políticas organizadas, assim como um ordenado aparato de Estado.

\footnotetext{
323“...der Wille irgend einen feierlichen Akt, eine Relligio, ein welthistorisches Ereignis, eine Haupt-und Staatsaktion, kommemorativ zu verewigen..... Ibidem, pp.229.

324“...material stage of primitive domestic building". HERRMANN, Semper's position on the primitive hut. In:_ Gottfried Semper: in search of architecture, op.cit., p.169.

325 "The general history of culture of mankind gives us evidence of the following important fact: namely that the history of architecture does not begin at the same point with the history of housebuilding and engineering". SEMPER, On architectural symbols, op.cit., p.62. Apesar de o autor observar uma evolução entre a criação de abrigos e a Arquitetura, ele não demonstra crer em uma visão linear do desenvolvimento histórico-cultural das civilizações, uma vez que as condições precárias ou primitivas dos povos em estágios anteriores poderiam facilmente indicar um momento de declínio em que os artefatos são meras reminiscências de grandes estágios civilizatórios do passado.
} 
Semper acredita que, para construir e reunir o corpo coletivo do Estado, os monumentos, e neles os ornamentos, cumprem um papel fundamental. Retomando um discurso tradicional, que remete à Retórica antiga, ${ }^{326}$ para o autor do Der Stil, o Ornamento é o responsável por fazer o monumento "falar" aos espectadores:

as praças e monumentos são dignitários antigos e sagrados do povo, eles valem não para serem escondidos e se tornarem não reconhecíveis, mas sim para evidenciar, apropriadamente, de um modo suspreendentemente animado e novo, a ocasião; eles, por assim dizer, através do adorno emprestado, em uma elocução improvisada, dirigem-se ao povo sobre o motivo da festa [...] Através do Ornatus e dos argumentos inseridos neles, eles tornavam-se festivamente animados, a ele [ornato] era emprestado o órgão para se conversar, em voz alta, como um antigo conhecido, com o povo, sobre as circunstâncias de seus tempos. ${ }^{327}$

\section{Diferentemente dos tempos hodiernos oitocentistas, em que parece ganhar cada vez mais destaque na cultura artística o aspecto prático e econômico, 328 os povos antigos, para o teórico hamburguês, tinham "provavelmente menos qualificações práticas e certamente mais poéticas": ${ }^{329}$}

ao preparar e modelar aos blocos de madeira e pedra em vigas prismáticas e cilindros de modo a fazê-los adequar-se à construção de seus templos e de outras obras arquitetônicas, eles não poderiam deixar de conferir a eles uma espécie de vida plástica. ${ }^{330}$

\footnotetext{
${ }^{326}$ Conferir capítulo 1.

327 "Die Plätze und Monumente waren alte geheiligte Würdenträger des Volks, die es galt, nicht zu verhüllen und unkenntlich zu machen, sondern der Gelegenheit entsprechend in überraschend festlicher und neuer Weise hervorzuheben, sie gleichsam durch den ihnen geliehenen Schmuck eine improvisirte, die Veranlassung des Festes betreffende Allokution an das Volk halten zu lassen [...] Durch den Ornatus und die ihm eingefügten Argumenten wurden sie nur festlichbeseelt, wurde ihnen das Organ sich as alte Bekannte vernehmlich mit dem Volke über die Zeitumstände zu unterhalten geliehen". SEMPER, Der Stil, v.l, op.cit., p.291.

${ }^{328}$ No Der Stil, o autor critica a ênfase realista da educação artística de sua época, dominada, em grande medida, pela perspectiva da ciência, que acredita que na construção os aspectos práticos são a essência da Arquitetura: "quando os povos se encontram sob o ponto de vista da cultura artística [...], a verdadeira educação do povo é idealista, no momento, ela é totalmente o oposto, a saber, realista. As ciências exatas assumiram a direção". Tradução de "Während der Zeit in welcher sich die Völker auf dem Standpunkte der künstlerichen Bildung befinden [...] ist die eigentlich Volkserziehung idealistisch, jetzt ist sie von Grund aus das Gegentheil, nämlich, realistisch; - die exakten Wissenschaften haben die Leitung derselben übernommen". Ibid, p. VIII, grifo do autor.

329 "[People of old $]$ had probably less practical but certainly more poetical qualifications". SEMPER, On architectural symbols, op.cit., p.62.

330 "They could not help giving a sort of plastical life to the blocks of wood or stone, in preparing and modelling them into prismatic beams or cylinders in order to make them fit for the construction of their temples and other architectural works". Id.Ibid., p.62.
} 
É papel do Ornamento conferir às partes da construção uma "vida plástica", ou seja, animá-la, de preferência na pedra. Os ornatos, em uma linguagem simbólica, contam, nos monumentos, as fábulas e histórias dos povos antigos, "a razão de sua existência, a direção e poder de sua ação, o papel e a parte destinados a eles em toda a obra, e como suas relações serviriam para ensinar uns aos outros; por quem e para qual destinação toda a construção foi feita". ${ }^{331}$ Isto ocorre ao perpetuar na pedra o que antes era feito com matérias mais perecíveis e era pendurado nas estruturas móveis improvisadas.

Tal é o caso dos antigos tapetes decorativos; antes pendidos na armação de madeira, encerrando o espaço, são reproduzidos na pedra. Mesmo quando, com o aperfeiçoamento técnico das culturas, se por questões de durabilidade, segurança ou proteção, paredes sólidas de tijolo, pedra ou qualquer outro material mais resistente surgiu, os tapetes decorativos continuam a "falar" simbolicamente aos espectadores, pois continuam sendo os "limites visíveis do espaço", ${ }^{332}$ na forma de um revestimento da parede sólida atrás. Semper esclarece:

como o trançado foi o original, assim ele reteve também mais tarde - quando as paredes leves de tapete se transformaram em sólidas paredes de ladrilhos, tijolos ou pedra de cantaria -, [...] toda a importância de seu significado anterior, a verdadeira essência da parede [...] A parede reteve este significado quando se a substituiu por outro que os materiais originais, atendendo a maior durabilidade ou para melhor conservação da parede atrás, ou por economia, ou, ao contrário, para apresentação de maior suntuosidade, ou por quaisquer outros motivos. ${ }^{333}$

Para Semper, os monumentos dos povos antigos, sem exceção, eram todos inteiramente revestidos, e este revestimento poderia ser feito por diversos meios e materiais, geralmente placas de pedra em relevo e pintadas, ou até mesmo só pintura. Ali a decoração é esculpida na pedra e pintada ou pintada no

\footnotetext{
331 "...the reason for their existence, the direction and power of their action, the role and part which they were destined to take in the whole work, and how their relations would be to teach each other; [...] by whom and for what destination the whole construction was made". Id.lbid., p.62.

332 "O tapete permaneceu sendo a parede, o limite visível do espaço". Tradução de "Es blieb der Teppich die Wand, die sichtbare Raumbegrenzung". SEMPER, Die vier Elemente..., op.cit., p.58.

333 "Wie das Flechtwerk das Ursprüngliche war, so behieltes auch später, als die leichten Mattenwände in feste Erdziegel - Backstein - oder Steinquadermauern sich umgestalteten, [...] die ganze Wichtigkeit ihrer früheren Bedeutung, das eigentliche Wesen der Wand [...] Diese Bedeutung behielt die Wand selbst dann, als man sie aus Rücksichten größserer eigener Dauer, oder zu besserer Erhaltung der dahinter befindlichen Mauer, oder aus Sparsamkeit, oder umgekehrt zu Entfaltung größserer Pracht, oder aus was immer für Gründen, durch andere als die ursprünglichen Stoffe ersetzte”. Ibidem, pp.57-58.
} 
próprio suporte. Isto tudo sugere que a Arquitetura, para Semper, não existe sem pintura e escultura, o monumento é em si mesmo uma coletividade das artes, conduzida pela Arquitetura. ${ }^{334}$

Como é possível notar, esse ponto de vista do estudioso hamburguês sobre a Arquitetura contraria a tradição do classicismo alemão, que desde os escritos de Winckelmann observava o valor ideal da arte, particularmente da arte grega, na forma ${ }^{335}$ - exaltada no branco do mármore helênico e para cuja apreciação a cor seria um obstáculo. ${ }^{336}$ Semper ainda avalia que, no momento em que pintura e escultura se separam da Arquitetura, o que há é só decadência. ${ }^{337}$

O mais relevante dessa concepção de Arquitetura é que o revestimento reteve a importância simbólica da antiga divisória vertical colorida e decorada.

334 O termo Gesamtkunstwerk, que pode ser traduzido como "síntese das artes", é costumeiramente atribuído ao compositor Richard Wagner, amigo de Semper. Mas o autor do Der Stil, já desde sua primeira obra publicada, antes dele conhecer Wagner, manifesta este ponto de vista sobre as artes. Nessa publicação ele diz: "Já desde seu primeiro desenvolvimento a partir do embrião, o qual a necessidade humana chamou à vida, as artes aparecem a nós em uma relação de íntimo crescimento, cuja dissolução só poderia ocorrer violentamente e ter como consequência um inevitável enfraquecimento ou empobrecimento". Tradução de "Schon seit ihrer frühesten Entwickelung aus dem Keime, den das menschliche Bedürfniss in's Leben rief, erscheinen uns die Künste in einen engverwachsenen Zusammenhange, dessen Auflösung nur gewaltsam geschehen konnte, und unvermeidlich Entkräftung oder Entartung zur Folge hatte". SEMPER, Vorläufige Bemerkungen über bemalte Architectur und Plastik bei den Alten, op.cit., p.3.

335 Conferir especialmente WINCKELMANN, Johann Joachim. Historia del arte en la Antiguedad. Trad. Manuel Tamayo Benito. Madrid: Ed. Aguilar, 1955. A visão branca da escultura e da arquitetura, como se sabe, teve imensa fortuna entre estudiosos alemães da segunda metade do século XVIII e começo do XIX, principalmente devido aos escritos de Kant que reafirmaram a supremacia da forma em detrimento da cor, mero atrativo. Em sua obra Crítica da faculdade do juízo, o filósofo afirma que "...na pintura, escultura, enfim, em todas as artes plásticas; na arquitetura, na jardinagem, na medida em que são belas artes, 0 desenho é o essencial, no qual não é o que deleita na sensação, mas simplesmente o que apraz por sua forma, que constitui o fundamento de toda disposição para o gosto. As cores que iluminam o esboço pertencem ao atrativo; elas, na verdade, podem vivificar o objeto em si para a sensação, mas não torná-lo belo e digno de intuição; antes, elas em grande parte são limitadas muito por aquilo que a forma bela requer, e mesmo lá, onde o atrativo é admitido, são enobrecidas unicamente por ela". KANT, Immanuel. Crítica da faculdade do juízo. RJ: Ed. Forense universitária, 2005, parág. 14, p.71.

336 Semper critica em diversas frentes a tradição do classicismo de Winckelmann - quem demonstrou, segundo o autor do Der Stil, certa incompetência em avaliar obras de arquitetura - e da escola idealista que se seguiu. Em um de seus manuscritos contendo uma de suas conferências na Academia de Arquitetura de Dresden, o teórico analisa os papéis de Winckelmann e Lessing na História da Arte e finaliza criticando ironicamente a escola idealista que se consolidou: "Winkelmann manifestou-se com ardor e atirou tudo ao chão àqueles que tomavam emprestado o antigo não de regras de beleza baseadas em si mesmas, mas ao deteriorado, sobretudo difundido gosto da arte francesa do século 18. Lessing o seguiu e tiranizou a arte, posto que estava empenhado em encerrá-la em limites estreitos e rigoroso em separar as artes individuais. Felizmente faltou isto a ele, apesar de sua clara perspicácia em um sentido verdadeiro da arte e em toda sua competência em matérias de arte. Daí resultou a escola idealista que somente autorizou a expressão da verdadeira beleza na arte". Tradução nossa de "Winkelmann trat mit Feuereifer auf und warf mit ganz denen der Antike entlehnten, aber nicht auf sich selbst gegründeten Schönheitsregeln, den verderbten über all verbreiteten Geschmack d. franz. Kunst d. 18. Jhs. zu Boden. Lessing folgte ihm und tyrannisirte die Kunst, indem er sie in enge Schranken einzuschließen und die einzelnen Künste scharf zu sondern bemüht war. Zum Glück fehlte es ihm, trotz seines hellen Scharfsinnes an eigentlichem Kunstsinn und an aller Sachkenntniß im Kunstfache. Es folgte hierauf die idealisirende Schule die nur den Ausdruck des wirklich Schönen in der Kunst gestattete". SEMPER, Gottfried. Geschichte der Baukunst, Manuscrito n.19, Semperarchiv an der ETH Zürich, 1834, fol.5.

${ }^{337}$ Conferir nota 334. 
Ao evidenciar a aparência, aquilo que é visível aos olhos, que se dá a ver, ele evoca a essência da Arquitetura: o espaço ocupado. ${ }^{338}$ Pois, para Semper, ser é parecer:339 "a parede é aquele elemento arquitetônico que formalmente evoca e identifica externamente aos olhos o espaço cercado como tal, por assim dizer, absoluto e sem referência a conceitos secundários". 340

Ainda, o revestimento decorativo é aquilo que "anima" a construção no sentido de que ele mascara a realidade nua e crua da matéria construtiva, assim como o adorno mascara o estado de natureza do homem. Consoante Caroline van Eck, em Semper

a Arquitetura não é somente uma representação monumental de um ato momentoso mostrando ao espectador a decoração e o revestimento das partes estruturais ao lançar mão de formas que representam os ofícios primitivos da humanidade. Ela é também, mediante este próprio ato de revestir ou mascarar, uma negação da matéria e até da realidade mesma. ${ }^{341}$

Nesse sentido, a vida coletiva, em seu aspecto público, só é possível através do jogo de aparências, do jogo de máscaras que adornam e revestem o corpo social. Na perspectiva de Semper, a Arquitetura é item importante da cultura, enquanto fenômeno coletivo de experiências compartilhadas e essa partilha é viabilizada sobretudo pelo Ornamento, pelos símbolos decorativos que possibilitam o discurso arquitetônico.

\footnotetext{
338 É interessante perceber que no momento em que o também arquiteto e teórico Viollet-le-Duc defende em seus escritos o valor nervurável e de clareza construtiva das estruturas góticas e seus ornamentos para a prática contemporânea, Semper sustenta uma validade sensória e significante da "parede-recinto", usando uma expressão de Stéphane Huchet (Horizonte tectônico e campo "plástico" - de Gottfried Semper ao grupo Archigram. Pequena genealogia fragmentária. In: MALARD, Maria Lúcia (org). Cinco textos sobre arquitetura. BH: Editora da UFMG, 2005, pp.169-233). A exaltação da parede-recinto, neste sentido, vai de encontro à promoção contemporânea da engenhosidade e do progresso das estruturas metálicas e das vedações em vidro, cada vez mais exploradas pelas tendências construtivas da época, como ficou explícito no sucesso de público do Crystal Palace londrino. Igualmente, no momento em que os discípulos de Durand levam a cabo os ensinamentos do mestre de prevalência do esquema planimétrico da grade estrutural, Semper reconhece e defende o valor do elemento vertical da parede, elemento relacional ao corpo humano, enquanto definidor do espaço, dando, a seu modo, continuidade ao prestígio e à importância que o corpo possuía na Tradição Clássica.

${ }^{339}$ Daí o fato de Semper, em uma nota de rodapé do Der Stil (vol.l, op.cit., p.231, nota 2), já muito comentada, exaltar o espírito do carnaval e de festividades semelhantes, como, por exemplo, o teatro, como a verdadeira atmosfera da arte, ou seja, o espaço onde se joga, onde, ao se vestir ou revestir, se dissimula a realidade ordinária.

340 "Die Wand ist dasjenige bauliche Element, das den eingeschlossenen Raum als solchen gleichsam absolute und ohne Hinweis auf Seitenbegriffe formaliter vergegenwärtigt und äusserlich dem Auge kenntlich macht". SEMPER, Der Stil, vol. I, op.cit., p.227.

341 "Architecture is not only a monumental representation of a momentous act, offering the viewer the decorativon and dressing of the structural parts by making use of forms that represent the primitive crafts of mankind. It is also, by this very act of dressing or masking, a negation of matter and even reality itself'. ECK, Caroline van. Figuration, tectonic and animism in Semper's Der Stil. In: The journal of architecture, volume 14, number 3, 2009 , pp.327.
} 
$\mathrm{Na}$ teoria de Semper, a localização da origem do Ornamento nos ofícios e sua posterior consagração em motivos esculpidos e pintados no monumento estabelece uma relação de continuidade entre as chamadas artes menores e maiores. Tal posicionamento teórico, como coloca Rykwert, contraria toda uma tradição erudita que observava uma ruptura entre os primeiros indivíduos fabricadores de artefatos e aqueles posteriores fabricadores de imagens. ${ }^{342}$ Longe de ser algo secundário ou supérfluo, o Ornato, para Semper, atende a um "notável fenômeno histórico-cultural", o adornar, ${ }^{343}$ apreciação que o leva a investigar o modo como as culturas historicamente fabricaram os Ornamentos e, consequentemente, como eles deveriam ser fabricados na época hodierna -, ou seja, a ideia do Estilo.

\footnotetext{
${ }^{342}$ Segundo Rykwert, para muitos cientistas sociais e historiadores da arte contemporâneos a Semper, "o progresso do homem da formação de rudes ferramentas à fabricação de belas imagens parecia tão natural quanto qualquer parte do processo evolutivo, e a continuidade que isto implicava não admitia a visão abrupta e integrada do processo de fatura que Semper sustentava. Tradução nossa de "the progress of man from the shaping of rough tools to the making of beautiful images seemed as natural as any part of the evolutionary process, and the continuity which this implied did not admit the abrupt and integrated view of the making process which Semper held'. RYKWERT, Semper and the conception of style, op.cit., p.129. 343 "Das Schmücken ist in der That eine sehr merkwürdige kultur-historische Erscheinung!" SEMPER, Über Baustyle, p.13.
} 


\section{ORNAMENTO E ESTILO}

Por ser um fenômeno histórico-cultural, a atitude de ornamentar a si e às coisas modifica-se no tempo e no espaço, adaptando-se de acordo com as diferentes culturas; é o que percebe Semper. E se as condições modernas revelavam uma crise no campo artístico da ornamentação, no sentido de "causarem temporariamente confusão nos campos daquelas capacidades do homem relacionadas com o discernimento e a representação da beleza", ${ }^{344}$ as culturas do passado, tanto dos grupos primitivos quanto dos antepassados ocidentais, traziam grandes lições a ensinar. ${ }^{345} \mathrm{O}$ teórico hamburguês acredita que uma alternativa viável para essa situação temporária de crise é o estudo do modo como essas culturas anteriores, no seu estágio de excelência artística, ornamentavam. Isto é, é necessário investigar os Estilos do passado para orientar-se artisticamente no presente.

Perscrutar os Estilos com vistas a deduzir princípios para a prática contemporânea foi o maior empreendimento da trajetória teórica de Gottfried Semper e que o consagrou com a obra que leva como título este tema. Mas investigar o tema do Estilo não foi uma contribuição exclusiva do autor do Der Stil. O século XIX, marcado por experiências revivalistas no campo da Arquitetura, ${ }^{346}$ foi também aquele no qual o conceito de Estilo foi intensamente discutido por intelectuais europeus após sua interpretação tradicional, em fins do século anterior, ter sofrido modificações.

A partir de sua acepção pela Retórica antiga, o conceito de Estilo havia sido apropriado pela doutrina acadêmica clássica na era Moderna. Durante este

\footnotetext{
344 “...nur zeitweilige Verwirrung auf dem Gebiete derjenige Fähigkeiten des Menschen veranlassen, die sich in dem Erkennen und Darstellen des Schönen bethätigen..." SEMPER, Der Stil, v.I, op.cit., p.V.

345 "Se fatos individuais tivessem a força de demonstração, então o reconhecido triunfo dos povos semibárbaros, sobretudo os indianos em alguns pontos com sua magnífica arte industrial, seria suficiente para provar que nós com nossa ciência até agora ainda não alcançamos muito nestes pontos. Esta mesma vergonhosa verdade se impõe quando nós comparamos nossos produtos com aqueles de nossos antepassados". Tradução de "Hätten einzelne Thatsachen Beweiseskraft, so würde der anerkannte Sieg, den die halbbarbarischen Völker, vor allen die Indien, in einigen Punkten mit ihrer herrlichen Kunstindustrie über uns davon trugen, genügen, um darzuthun, dass wir mit unserer Wissenschaft in diesen Punkten bis jetzt noch nicht viel ausgerichtet haben. Dieselbe beschämende Wahrheit drängt sich auf, wenn wir unsere Erzeugnisse mit denjenigen unserer Vorfahren vergleichen". SEMPER, Wissenschaft, Industrie und Kunst, op.cit., p.11.

${ }^{346}$ Luciano Patetta denomina ecletismo o período compreendido entre 1750 e 1900, que foi marcado por diversas experiências revivalistas, os revivals ou estilos históricos, em um contexto de consolidação da cultura burguesa, desenvolvimento da civilização industrial e da produção em massa, dentre outros. Cf. PATETTA, Luciano. Los revivals en arquitectura, op.cit.
} 
período, ele era de um modo geral entendido, consoante Caroline van Eck, "no sentido da maneira de trabalho característica de um particular artista, e no sentido de uma hierarquia de estilos que correspondiam à hierarquia de propósitos e gêneros", 347 como, por exemplo, no caso da pintura, o estilo elevado era reservado às pinturas históricas. Na teoria da Arquitetura, tal conceito só foi utilizado com frequência a partir do século XVIII, ${ }^{348}$ caracterizando uma comparação da Arquitetura à poesia e das ordens aos gêneros poéticos, em que a escolha do Ornamento ou de uma ordem arquitetônica específica evocava determinados temperamentos emocionais que deveriam estar de acordo com a destinação da edificação. ${ }^{349}$

As mudanças processadas no conceito de Estilo nos fins dos setecentos podem ser observadas nos escritos de Quatremère de Quincy. A definição do termo Style da última versão de seu Dictionnaire já havia aparecido na Encyclopédie Methodique, escrita ainda no fim do século dezoito. Neste conteúdo, o autor apresenta duas definições do termo. A primeira remete ao sentido estabelecido na tradição da Retórica, na medida em que se refere "à forma que o escritor dá ao conjunto de seus pensamentos, segundo a natureza do assunto que ele trata, dos efeitos que ele quer produzir, e do acordo deste meio com o objetivo ao qual ele deve buscar". ${ }^{350}$ A segunda acepção, como o próprio autor declara, aborda o termo em um sentido mais geral - no qual se inserem também, segundo ele, as artes do desenho - como sendo "esta forma típica e característica que causas gerais imprimem às produções do espírito, segundo as diferenças de climas, de impressões físicas, de hábitos, de costumes, da ação dos governos, e de instituições políticas ou morais". ${ }^{351}$ Ainda, neste sentido geral, Estilo, para Quincy, se tornaria sinônimo de caráter, ou "da

\footnotetext{
347 "...in the sense of the working manner characteristic of an individual artist, and in the sense of a hierarchy of styles that corresponded to a hierarchy of aims and genres.... ECK, Caroline van. Classical rhetoric and the visual arts in early modern Europe. Cambridge: Cambridge university press, 2007, p.194.

348 Momento em que acompanhou a teoria do caráter, mais particularmente, a partir de 1714 na GrãBretanha, e a partir de 1750 na França, segundo van Eck (lbid.).

349 ld. Ibid.

350"...la forme que l'écrivain donne à l'ensemble de ses pensées, selon la nature du sujet qu'il traite, des effets qu'il veut produire, et de l'accord de ce moyen avec le but auquel il doit tendre". QUATREMÈRE DE QUINCY, Antoine-Chrysostôme. Dictionnaire historique d'architecture...,1832, op.cit., Tome Second, verbete Style, p.501.

351 “...cette forme typique et caractéristique que des causes très-générales impriment aux productions de l'esprit, selon les différences des climats, des impressions physiques, des habitudes, des moeurs, de laction des gouvernemens, et des institutions politiques ou morales". Ibid., p.501.
} 
maneira própria, da fisionomia distintiva, que pertencem à cada obra, à cada autor, à cada gênero, à cada escola, à cada país, à cada século, etc."352

Apesar dos argumentos usados por ele ainda apresentarem referência na tradição da Retórica, nota-se que já não se sustentam na validade universal do classicismo. Particularmente sua segunda definição sugere uma noção de Estilo conforme este conceito passa a ser compreendido no século XIX, como uma expressão relativa a condições particulares, ou seja, condicionada a variáveis e não mais fundamentada no valor absoluto da linguagem clássica como padrão de gosto. Os chamados estilos históricos, a partir de então, são muitos e não mais se restringem à hierarquia de gêneros clássica.

O reconhecimento dessa variedade estilística no século XIX foi motivado pelas investigações em curso no campo da Arqueologia - cujas descobertas, desde o século XVIII e ao longo de todo o XIX, não somente permitiram um conhecimento maior e mais objetivo das construções arquitetônicas da Antiguidade clássica, assim como também de outras culturas, como as orientais $^{353}$ - e pelas decorrentes atividades taxonômicas dos historiadores da arte, a quem, muitas vezes, segundo aponta Rykwert, "parecia que a marca de qualquer estilo era um repertório de ornamentos". 354

$\mathrm{Na}$ atividade prática da Arquitetura, se antes a compreensão do Estilo remetia a uma linguagem comum a partir da qual se criava, no século XIX ela acabou se caracterizando como uma pluralidade de sistemas linguísticos, cada um pressupondo uma suposta unidade estilística mediante determinado conjunto de formas construtivas e de tipos ornamentais e, com isso, cada um evocando significados e valores associados às imagens do passado que a cultura em questão possibilitava imaginar. ${ }^{355}$

\footnotetext{
352 “...de la manière propre, de la physionomie distinctive, qui appartiennent à chaque ouvrage, à chaque auteur, à chaque genre, à chaque école, à chaque pays, à chaque siècle, etc." lbid., p. 501.

${ }^{353} \mathrm{O}$ maior conhecimento destas últimas contribuiu também para provocar certa fascinação e reforçou o gosto pelo caráter "exótico" atribuído a elas. Este tipo de atribuição de sentidos foi recorrente na interpretação dos estilos e pode-se dizer que foi decorrente também da capacidade imaginativa de tramar imagens de culturas passadas, prática em partes decorrente daquilo que Patetta designa como Teoria Associacionista, em que as formas da arquitetura passam a ser interpretadas a partir das sensações e emoções que provocam na mente do espectador. Cf. PATETTA, Luciano. Los revivals en arquitectura, op.cit.

${ }^{354}$ RYKWERT, Joseph. A coluna dançante, op.cit., p.349.

355 Conforme nota 353.
} 
Com o fim do valor absoluto do clássico, Estilo passou a ser uma questão de escolha, ${ }^{356}$ conforme sugere a publicação do arquiteto Heinrich Hübsch (1795-1863), de 1828, que questionava Em que estilo devemos construir? e que provocou intenso debate teórico no ambiente intelectual das regiões de língua alemã, em meio à difusão dos revivalismos. ${ }^{357}$ Segundo Günther Irmscher, nas principais potências europeias, a escolha de um estilo do passado veio também suprir uma necessidade de legitimação política e ideológica antes exercida pela hegemonia da tradição greco-romana. ${ }^{358}$ Naturalmente, em muitos estados essa escolha não ocorreu sem disputas e conflitos simbólicos, ${ }^{359}$ como foi o caso do concurso para as novas instalações do parlamento britânico em meados do século, celebrizado por determinada historiografia da Arquitetura e indicado como a "batalha dos estilos". 360

\footnotetext{
${ }^{356}$ Conforme expõe Leonardo Benevolo, se por um lado esta escolha implicava em uma liberdade ao artista no sentido da variedade estilística a sua disposição, por outro lado, o conhecimento mais acurado e objetivo dos monumentos não permitia muitas variações individuais: "[...] a unidade da linguagem, de um ponto de vista, parece definitivamente garantida, pois o conhecimento objetivo dos monumentos históricos permite imitar um dado estilo passado com toda a fidelidade possível; mas os estilos são muitos, e apresentam-se ao mesmo tempo na mente do projetista, daí ser o repertório historicista, em seu conjunto, absolutamente descontínuo [...] $\mathrm{Na}$ aplicação concreta de cada estilo vale o critério da fidelidade histórica; o artista pode aceitar tais referências ou recusá-las, ou manipulá-las, porém as recebe de fora e não possui uma margem (teoricamente) para assimilá-las a seu modo, porque não se trata de modelos ideais, mas sim de exemplos reais que podem ser conhecidos pela experiência. Pelo contrário, em abstrato, o projetista goza de uma liberdade ilimitada, pois pode decidir em termos absolutos se irá empregar o estilo A ou o estilo B". BENEVOLO, História da arquitetura moderna, op.cit., p.29.

357 In welchem Style sollen wir bauen? Karlsruhe: Chr. Fr. Müller Hofbuchhandlung und Hofbuchdruckeren, 1828. A obra foi traduzida para o inglês e publicada em uma coletânea com uma série de outros textos de arquitetos que, na época, procuraram de certo modo "responder" ao questionamento de Hübsch. Cf. HÜBSCH, Heinrich et.al. In What Style Should We Build? The German Debate on Architectural Style. Trans. Wolfgang Herrmann. Santa Monica: Getty Center for the History of Arts and the Humanities, 1992. Segundo Wolfgang Herrmann, no ambiente intelectual de língua alemã, nas tentativas teóricas de responder ao questionamento de Hübsch, "valores tradicionais foram sustentados em oposição a propostas radicais, e uma abordagem materialista foi oposta a um ponto de vista idealista". Tradução nossa de "...traditional values were upheld against radical proposals, and a materialistic approach was opposed by an idealistic point of view.". HERRMANN, Wolfgang. Introduction. In: HÜBSCH, Heinrich et.al. In What Style Should We Build?, op.cit., p.1.

358 IRMSCHER, Kleine Kunstgeschichte des europäischen Ornaments seit der frühen Neuzeit (1400-1900), op.cit., p.286.

${ }^{359}$ Sobretudo tendo em vista a emergência dos ideais românticos e nacionalistas que se difundiram por boa parte do século. Com o declínio das monarquias absolutistas de direito divino e a formação dos estadosnação modernos, passava a ser necessário criar signos que denotassem identidades próprias, e os monumentos arquitetônicos não deixavam de ser alguns dos meios mais adequados para isto. Os valores evocados por determinado estilo representavam, para alguns, como determinada sociedade se via ou gostaria de ser vista a partir de então. Assim sendo, os estilos não eram simples evocações nostálgicas do passado, mas principalmente contribuíam para formar o tempo presente, no sentido, por exemplo, de tentar aplicar soluções formais do passado à realidade da época. O fato é que, seja a defesa do clássico como um ideal atemporal a ser consumado no novo estado germânico, como sustentada por Leo von Klenze e Karl Friedrich Schinkel, seja a do gótico ou do Rundbogenstil - estilo que explora o sistema construtivo de arcos de volta perfeita, semelhante ao românico - como uma linguagem estrutural e econômica adequada às necessidades do presente por Viollet-le-Duc e por Heinrich Hübsch respectivamente, todos buscavam, mediante variados argumentos, demonstrar a superioridade de cada linguagem, que serviria para constituir a expressão apropriada da contemporaneidade.

360 Parte da narrativa deste acontecimento, que envolveu inclusive a imprensa britânica da época, é encontrado em PEVSNER, Nikolaus. Os pioneiros do desenho moderno: de William Morris a Walter Gropius. SP: Martins Fontes, 1980, pp.25-26. A disputa em questão evidenciou uma luta simbólica entre os
} 
Desta forma, em meio ao confuso panorama arquitetônico devido ao impasse na questão que se colocava sobre em qual estilo os novos estados nações deveriam basear suas edificações, Gottfried Semper propõe investigar o Estilo, no singular, em contraposição aos estilos, no plural. ${ }^{361} \mathrm{O}$ estudioso rejeita compreender o Estilo como uma escolha formal do passado, assim como "protesta contra uma utilização nacional dos estilos"362 e apresenta sua teoria sobre este tema como uma tarefa prática, que propunha-se "procurar, nos casos individuais, a regularidade e a ordem que se evidenciam nos fenômenos artísticos durante o processo do tornar-se e do surgir", ${ }^{363}$ e pretendia, com isso, "obter, a partir do que se encontrar, princípios gerais, os fundamentos de uma teoria empírica da arte". 364

Este capítulo pretende demonstrar como, no conceito de Estilo elaborado por Semper, ${ }^{365}$ o Ornamento não é o repertório decorativo fixo que caracteriza uma linguagem convencional do passado e que deveria ser copiado para evocar valores formadores do presente. Guardando similitudes aos propósitos expostos nas principais preceptivas clássicas, também em Semper, o Ornamento, item fundamental do Estilo, é o artifício que possibilita à Arquitetura transmitir sentidos a partir das escolhas do arquiteto, tendo em vista a correspondência a uma ideia de sua época.

\footnotetext{
defensores do neogótico e os dos valores clássicos representados então pelo estilo neopaladiano. Segundo Pevsner (Ibidem, p.25.), foi Lorde Palmerston, um dos responsáveis pelo julgamento do concurso, quem classificou o episódio como "a batalha do estilo gótico contra o estilo paladiano".

361 Ideia que também se pode observar nos escritos de Viollet-le-Duc, que inicia o verbete Estilo da versão de 1866 do Dictionnaire raisonné de l'architecture apontando para que "existe o estilo" e "existem os estilos" ("Il y a le style; il y a les styles". VIOLLET-LE-DUC, Eugène Emmanuel. Dictionnaire raisonné de l' architecture française du XIe au XVe siècle. Paris: A. Morel éditeur, 1866, vol.8, verbete Style, p.474). 0 autor diferencia entre estilos remetendo à atividade taxonômica do século XIX que reconheceu e classificou vários estilos artísticos ao longo da história e em diferentes localidades - noção relativa de estilo já indicada nos escritos de Quincy - , e Estilo como uma questão de qualidade expressiva pertinente à própria atividade artística e intelectual do artista, ou, como o próprio autor fala, como "uma concepção do espírito", tratandose, neste caso, para ele, da "manifestação de um ideal estabelecido sobre um princípio ou seja, sobre os próprios princípios racionais construídos por ele como válidos e legítimos para a Arquitetura ("Nous ne parlerons donc que du style qui appartient à l'art pris comme conception de l' esprit. [...] C'est, dans une oeuvre d'art, la manifestation d'un ideal établi sur un principe"). Ibid., p.474.

362 “...verwahrt er [Semper] sich gegen eine nationale Inanspruchnahme von Stilen”. ORELLI-MESSERLI, Barbara von. Gottfried Semper (1803-1879). Die Entwürfe zur dekorativen Kunst. Petersberg: Michael Imhof Verlag, 2010, p.23.

363 "...die bei dem Prozess des Werdens und Entstehens von Kunsterscheinungen hervortretende Gezetzlichkeit und Ordnung im Einzelnen aufzusuchen...". SEMPER, Der Stil, vol. I, op.cit., p.VI.

364 "...aus dem Gefundenen allgemeine Prinzipien, die Grundzüge einer empirischen Kunstlehre, abzuleiten". Id.Ibid.., p.VI.

365 Ao dedicar-se a investigar teoricamente o conceito de Estilo, o teórico hamburguês de certo modo coloca-se como um seguidor de uma tradição de pensadores de língua alemã que desde Winckelmann se empenharam na especulação teórica desta noção e com isso apresentaram importantes contribuições para a própria disciplinaridade da Arquitetura, como se nota no debate gerado pelo questionamento de Heinrich Hübsch.
} 


\subsection{Estilo como correspondência a uma ideia}

A tarefa prática proposta pela teorização do Estilo de Semper consiste em perscrutar princípios que pudessem servir como meio de invenção artística, ou, consoante acredita o autor, como estratégia para construir uma espécie de "estética prática" 366 para o artífice oitocentista. Com isso em mente, Semper, assim como todos os que debatiam o tema do Estilo na época, acreditava justamente estar tentando solucionar o problema contemporâneo de crise no campo artístico.

Em sua opinião, os principais motivos dessa crise localizavam-se na abundância de meios de fabricação, evidenciada pelas numerosas conquistas técnicas da indústria moderna, e na enorme expansão do conhecimento da época, que se expressava, por exemplo, pela grande quantidade e variedade de publicações técnicas e artísticas disponíveis. ${ }^{367}$ Para ele, a riqueza material e científica não trouxe semelhante evolução no campo artístico. Logicamente, o próprio Semper não deixava de participar - como produtor e também consumidor - deste contexto cultural de abundância de literatura especializada advinda de distintos campos do conhecimento, principalmente o histórico, o qual ele explora profusamente, como se pode notar nas inúmeras publicações e nos muitos autores que ele cita no Der Stil. ${ }^{368}$

O teórico hamburguês acredita que todos esses excessos eram prejudiciais para o artista, uma vez que ele (o artista) não desfrutava de tempo suficiente para dominar as informações teóricas e as inovações técnicas que surgissem, e, era justamente por isso que, nessa "quantidade de escritos artísticos, falta ainda um guia prático para invenção, que indique os recifes e bancos de areia a serem evitados e que apontasse para o firme ponto de direção". ${ }^{369}$

\footnotetext{
366 "praktische Aesthetik" inclusive faz parte do título geral do Der Stil. SEMPER, Der Stil, vols.I e II, op.cit. 367 Sobre esta crítica do autor conferir, por exemplo, SEMPER, Wissenschaft, Industrie und Kunst, op.cit., e também os prolegômenos do Der Stil, vol.I, op.cit.

368 Para tomar conhecimento dos autores e obras citados por Semper no Der Stil, conferir SEMPER, Gottfried. Style in the Technical and Tectonic Arts; or Practical Aesthetics. 2 vol. Trans. Harry Francis Malgrave and Michael Robinson. Los Angeles: Getty Research Institute, 2004, pp.921-946.

369"...Denn unter der Masse von artistischen und technischen Schriften fehlt es noch gänzlich an einer praktischen Hereutik, welche die Klippen und Sandbänke bezeichnet, denen man auszuweichen hat und die auf feste Richtungspunkte hinweist'. SEMPER, Wissenschaft, Industrie und Kunst, op.cit., p.14.
} 
No entanto, ele esclarece que sua teoria do Estilo não pretendia ser "um manual para a prática artística". ${ }^{370} \mathrm{Em}$ toda a teorização de Semper, o fato da historiografia nutrir a criação artística não implica em demonstrar ao artista "o [como] produzir de uma qualquer forma de arte, mas sim seu surgimento", ${ }^{371}$ ou seja, ele pretende evidenciar como ela se torna uma forma artística, o que se distancia de qualquer sugestão demonstrativa de um passo-a-passo criativo. Trata-se, como se pode perceber, de compreender a Gestaltung da obra, sua "formatividade", ou seja, seu processo ou capacidade permanente de formação e transformação - daí a importância da investigação das origens da atividade artística -, não a observando como algo absoluto em si.

Esse ponto de vista igualmente se distancia da proposta de oferecimento de padrões convencionais de ornamentos referentes a estilos do passado, conforme usualmente se observava nos famosos compêndios decorativos, como, por exemplo, na célebre publicação The grammar of ornament (1856), de Owen Jones, colega de Semper nas Schools of Design. ${ }^{372}$ Esta obra, a despeito de declaração contrária do autor - em que ele confessa desejar, com sua publicação, frear a tendência geral da cópia de ornamentos -, acabou tendo sido "rapidamente aceita como fonte definitiva de motivos ornamentais e reimpressa nada menos que nove vezes até 1910 ". 373

A cópia dos estilos e tipos ornamentais do passado é avaliada por Semper como uma atitude típica da escola histórica de sua época, uma das principais correntes de pesquisa científica e de aplicação nas artes à qual ele procura opor seu discurso teórico sobre o Estilo, uma vez que seus representantes, os

\footnotetext{
370 "[Eine solche Lehre darf] kein Handbuch der Kunstpraxis sein". SEMPER, Der Stil, vol. I, op.cit., p.VI. 371 ".....nicht das Hervorbringen einer beliebigen Kunstform, sondern deren Entstehen...". Id.Ibid., p.VI, grifos do autor.

372 Também Ralph Wornum, por exemplo, em seu texto sobre a exposição industrial de 1851, associava os estilos aos desenvolvimentos dos Ornamentos em diferentes épocas e nações, e para ele, "as obras de arte ornamental devem ser mantidas perfeitamente sujeitas aos simples princípios da beleza do arranjo das formas materiais". WORNUM, The exhibition as a lesson in taste, op.cit., p.I. Tradução de "works of Ornamental Art may be associated with ornament, but they must be kept perfectly subject to the mere principles of beauty of arrangement of the material forms". No mesmo texto, em outro local (p.II), ele coloca que "todos os estilos são somente muitos modos diferentes de usar a mesma linguagem, aquela do Ornamento" e reconhece nove: Egípcio, Grego, Romano, Bizantino, Sarraceno, Gótico, Renascença, Cinquecento e Luis XIV. Tradução de "all styles are only so many different ways of using the same language, that of ornament...".

373 ZACZEK, lain. Introdução [à edição brasileira da Grammar]. In: JONES, Owen. A gramática do Ornamento: ilustrado com exemplos de diversos estilos de Ornamento. Tradução de Alyne A. Rosenberg. SP: Ed. Senac São Paulo, 2010, p.15. Jones, do mesmo modo como era professado nas Schools of Design, procurou "resolver" o problema do Ornamento na época mediante a formulação de princípios universais bidimensionais de forma e cor, em grande medida desconsiderando as relações entre as formas e as culturas em que foram criadas.
} 
historicistas, influenciados pelos métodos críticos e classificatórios da história da arte e da pesquisa arqueológica, ao tomarem como modelo imitativo obras de tempos passados ou de outras nações, ${ }^{374}$ tentam "trabalhar nestes modelos as exigências do presente, ao invés de, como parece mais natural, desenvolver livremente a solução do problema das premissas como o presente as oferece." ${ }^{375}$. Ao fazer isto, acredita Semper, não se estimula o instinto artístico, ficando o artista enfraquecido em sua capacidade de guiar-se criativamente, e, para o autor, este também era um dos motivos da crise contemporânea. ${ }^{376}$

Outras duas correntes científicas da época são igualmente alvo de críticas por parte do teórico hamburguês por apresentarem caminhos que ele considerava inadequados. Uma delas seria a dos filósofos da Estética, os quais Semper, de maneira crítica, analisa como aqueles que apenas se preocupavam com a beleza na arte e em "trazer a beleza do mundo dos fenômenos de volta para a ideia". ${ }^{377} \mathrm{O}$ teórico hamburguês opõe-se a tais estudiosos, sustentando criticamente que eles apenas se empenhavam em especulações abstratas próprias a seu exercício intelectual e desconsideravam os aspectos práticos da arte, relativos à atividade criativa do artista. Um desses estudiosos da Estética a que o autor se refere negativamente nos prolegômenos do Der Stil é o matemático e filósofo Adolf Zeising (1810-1876). Zeising publicou duas obras na década de cinquenta que, segundo Mallgrave, ${ }^{378}$ ganharam proeminência na época, e das quais Semper coloca-se por vezes como interlocutor, Neue Lehre von den Proportionen des menschlichen Körpers (1854) ${ }^{379}$ e Ästhetische Forschungen (1855). ${ }^{380}$ Zeising deixa claro em seus escritos que ele pretendia estabelecer princípios fundamentais da beleza direcionados "não somente para

\footnotetext{
${ }^{374}$ Semper refere-se à historische Schule. A crítica às expressões revivalistas da época e à cópia de formas do passado é uma constante em seu discurso desde sua primeira obra publicada, no entanto, vale lembrar que o próprio Semper, mais tarde, por suas obras construídas, foi caracterizado como um historicista por teóricos modernos de princípios do século XX. Conferir, por exemplo, MUTHESIUS, Hermann. Style Architecture and Building-Art, op.cit., p.68.

375“...die Anforderungen der Gegenwart nach ihnen zu modeln, anstatt, wie es natürlicher scheint, die Lösung der Aufgabe aus ihren Prämissen, wie sie die Gegenwart gibt, frei heraus zu entwickeln...". SEMPER, Der Stil, vol. I, op.cit., p.XV.

376 Ibidem.

377“...Zurücktragen des Schönen aus der Erscheinungswelt in die Idee...”. SEMPER, Der Stil, vol. I, op.cit., pp. XVIII-XIX

${ }^{778}$ MALLGRAVE, Harry F. Gottfried Semper: architect of the nineteenth century, 1996, op.cit.

379 ZEISING, Adolf. Neue Lehre von den Proportionen des menschlichen Körpers: aus einem bisher unerkannt gebliebenen, die ganze Natur und Kunst durchdringenden morphologischen Grundgesetze entwickelt und mit einer volständigen historischen Uebersicht der bisherigen Systeme begleitet. Leipzing: Rudolph Weigel, 1854.

380 ZEISING, Adolf. Ästhetische Forschungen. Frankfurt an Main: Verlag von Meidinger Sohn und Comp., 1855.
} 
o esteta, mas também para o metafísico e para o filósofo"381, excluindo desta lista o artista, pois acreditava que os propósitos deste último eram distintos daqueles do esteta. ${ }^{382}$ Semper desaprova tal ponto de vista, uma vez que, como coloca Harry F. Mallgrave, o autor do Der Stil tinha a crença de que a "Estética deveria servir à arte e não se tornar um exercício intelectual isolado cheio de abstrações conceituais". 383

Sua crítica aos estetas abrange uma crítica à compreensão da beleza como "a combinação de formas individuais para [alcançar] um efeito geral"384, que supostamente agradaria e satisfaria nosso "senso artístico". ${ }^{385}$ Contrapondo sua teoria do Estilo a tais concepções, Semper argumenta que "há também uma concepção estilística daquilo que é belo na arte", ${ }^{386}$ que "concebe a beleza de modo unitário, como produto ou resultado, não como soma ou série. ${ }^{387}$ Os estetas, por exemplo, não abordavam a obra da perspectiva do material e do propósito a ser alcançado, aspectos que Semper considera fundamentais no conceito de Estilo, sobretudo em se tratando de artes decorativas e Arquitetura.

Essa consideração do ponto de vista do material na especulação teórica sobre o Estilo não deve ser creditada exclusivamente a Semper, já que outros teóricos também vinham discutindo a noção sob este viés. ${ }^{388}$ Uma das importantes referências do estudioso hamburguês foram os escritos do historiador da arte Karl Friedrich von Rumohr (1785-1843), quem Semper conheceu pessoalmente e cujas pesquisas teóricas mencionou em suas

\footnotetext{
381 "...nicht bloß für den Ästhetiker, sondern auch für den Methaphysiker und für den Philosophen...”. ZEISING, Ästhetische Forschungen, op.cit., p.VII.

382 lbidem.

383 "....aesthetics should serve art and not become an isolated intellectual exercise riddled with conceptual abstractions". MALLGRAVE, Gottfried Semper: architect of the nineteenth century, op.cit., p.273.

384“...ein Zusammenwirken einzelner Formen zu einer Totalwirkung...”. SEMPER, Der Stil, vol. I, op.cit., p.VI.

385 “...künstlerischen Sinn...”. Id. Ibid., p.VI.

386 "...[However], there is also a stylistic conception of what is beautiful in art...". SEMPER, Gottfried. The Attributes of Formal Beauty. In: HERRMANN, Gottfried Semper: in search of architecture, op.cit., p.241.

387 "[Die Stillehre dagegen] fasst das Schöne einheitlich, als Produkt oder Resultat, nicht als Summe oder Reihe..."SEMPER, Der Stil, vol. I, op.cit., p.VII, grifos do autor.

388 Desde fins do século anterior, estudiosos vinham progressivamente reconhecendo aspectos táteis, mecânicos e materiais como essenciais para a beleza da Arquitetura, como foi o caso, por exemplo, de Heinrich Hübsch e sua proposta do Rundbogenstil. (Conferir HÜBSCH, Heinrich et.al. In What Style Should We Build?, op.cit.). No meio intelectual de língua alemã, muito provavelmente um dos impulsos que suscitou essa perspectiva mais sensória para a Arquitetura foram os estudos de Herder sobre a escultura, apresentados em sua obra Plastik de 1778, em que o autor contraria a dominância exclusiva da percepção visual na abordagem da escultura, defendendo a valorização do tato (paralelamente a esta correspondência entre escultura e tato, estariam aquelas entre pintura e visão e música e audição). Conferir HERDER, Johann Gottfried. Escultura. Algunas observaciones sobre la forma y la figura a partir del sueño plástico de Pigmalión. Introd., trad. y notas de Vicente Jarque. València: universitat de València, 2006.
} 
publicações. ${ }^{389}$ Rumohr foi um erudito que, nas primeiras décadas do século XIX, fez oposição à tradição que advém dos estudos de Winckelmann e à perspectiva de abordagem da obra de arte sob o ponto de vista do ideal, argumentando pela importância da consideração de fatores como necessidade, propósito e material. No primeiro volume de sua obra Italienische Forschungen, Rumohr define estilo como a "conformação habitual bem sucedida às exigências internas do material", ${ }^{390}$ consideração que provavelmente levou Semper a caracterizá-lo como "o primeiro a traçar a noção de Estilo para sua verdadeira raiz empírica". 391

Apesar desse reconhecimento quanto à importância do material, Semper critica veementemente aqueles que acreditavam que "o mundo das formas arquitetônicas surge apenas das condições estruturais e materiais e somente [a partir] daí seria possível maior desenvolvimento". ${ }^{392}$ Trata-se de outra corrente científica da época, apontada pelo autor como materialista, e da qual ele cita como exemplo aqueles que, opondo-se à narrativa vitruviana da gênese da Arquitetura a partir de uma cabana original em madeira, defendiam a posição de que o templo dórico teria surgido diretamente das necessidades de um único material, a saber, a pedra. ${ }^{393}$ Este posicionamento teórico era o caso de Violletle-Duc, quem Semper também julga negativamente por sua (le-Duc) argumentação que as formas cilíndricas das colunas dos templos seriam resultado de seu rolamento nas descidas das pedreiras. ${ }^{394}$

O material, coloca Semper, "é somente um dos muitos fatores a cujas exigências internas o artista tem que se submeter e que é sua tarefa enfatizar". 395 Em seu ponto de vista, a ideia de Estilo não se refere somente à forma, ela trata dos "componentes da forma que não são a forma em si, mas sim ideia, força, material e meio, por assim dizer, os componentes prévios e as condições básicas

\footnotetext{
389 Segundo Harry Francis Mallgrave, Semper conheceu Rumohr ainda nos anos de juventude, no período em que esteve na Itália em meio a sua viagem às terras clássicas. Cf. Gottfried Semper: architect of the nineteenth century, op.cit. Conferir página 61.

390“...ein zur Gewohnheit gediehenes sich Fügen in die inneren Forderungen des Stoffes...”. RUMOHR, Karl Friedrich von. Italienische Forschungen. Berlin: Nicolai Verlag, vol I, 1827, p.87.

391 "[...Rumohr...] was the first to trace the notion of style to its true empirical root...". SEMPER, The atributes of formal beauty, op.cit., p.243.

392 "...es sei die arch.Formenwelt ausschliesslich aus stofflichen konstruktiven Bedingungen hervorgegangen und liesse sich nur aus diesen weiter entwickeln...". SEMPER, Der Stil, vol.I, p.XV, colchetes nossos.

393 SEMPER, Der Stil, vol. II, 1863, op.cit.

394 Ibidem, p.210, nota 1.

395 "[I believe that the 'crude material'] is only one of several factors the inner exigencies of which the artist has to submit to and which it is his task to emphasize". SEMPER, The attributes of formal beauty, op.cit., p.243, aspas do autor.
} 
da forma". ${ }^{396}$ A ideia de Estilo em Semper, além de não considerar a obra somente do ponto de vista de sua recepção formal, implica em conhecer os fatores variados que interferem no artefato, ou seja, que contribuíram em seu processo fenomênico.

Semper considera que há dois tipos de fatores, os internos e os externos à obra. Os fatores internos referem-se às "as exigências da própria obra e as quais estão baseadas em certas leis da natureza ou da necessidade, que são as mesmas em todos os tempos e sob toda circunstância". ${ }^{397}$ Nestes fatores internos, um dos itens a se analisar são os chamados motivos artísticos, ou seja, as idéias simbólicas que são incorporadas ou "vestidas" pelos tipos ou formas básicas - as formas mais antigas. ${ }^{398}$ Trata-se aqui, da "parte histórica da teoria do estilo", ${ }^{399}$ uma vez que se propõe a investigar as formas originárias e suas manifestações históricas, suas "roupagens" formais ao longo da história da arte. No Der Stil, Semper explora tanto os motivos da arte decorativa, que tiveram como expressão originária o Ornamento, quanto seu desenvolvimento posterior nos quatro motivos da Arquitetura.

Ainda considerando os aspectos internos da obra, o autor se refere a uma segunda parte da teoria como "teoria técnica do estilo", 400 que deveria especular "como com nossos meios as formas transformaram-se de modos diferentes a partir dos motivos, e como o material é tratado segundo princípios de estilo por nossa técnica avançada". ${ }^{401}$ Esta parte da teoria é a que Semper mais investiga no Der Stil, mas, por outro lado, também é a que ele reconhece dificuldades em estabelecer princípios válidos para as condições contemporâneas, considerando os avanços recentes da indústria no trato com os materiais.

Já dentre os fatores externos à obra em si, Semper reconhece as "influências locais, temporais e pessoais", ${ }^{402}$ como, por exemplo,

\footnotetext{
396 "[Sie sucht] die Bestandtheile der Form die nicht selbst Form sind, sondern Idee, Kraft, Stoff und Mittel; gleichsam die Vorbestandtheile und Grundbedingungen der Form". SEMPER, Der Stil, vol. I, op.cit., p.VII, grifos do autor.

397 "... the exigencies of the work itself and which are based upon certain laws of nature and of necessity, which are the same at all times and under every circumstance". SEMPER, London lecture of November 11, op.cit., p.11.

398 Ibidem.

399 “... historische Theil der Styllehre...”. SEMPER, Wissenschaft, Industrie und Kunst, op.cit., p.17.

400 "...technischen Styllehre...". Ibidem, p.18.

401“.... wie mit unseren Mitteln sich die Formen aus den Motiven anders zu gestalten haben, und wie das Stoffliche bei unserer fortgeschrittenen Technik nach Stylgrundsätzen zu behandeln sei..... Ibidem., p.17.

402“...örtlichen, zeitlichen, persönlichen Einflüsse...”. Ibidem., p.19.
} 
a constituição climática e física de um país, as instituições políticas e religiosas de uma nação, a pessoa ou a corporação pela qual a obra é solicitada, o lugar para o qual é destinada, e a ocasião na qual foi produzida. Finalmente, também a personalidade individual do artista. ${ }^{403}$

Observa-se que Semper, de certo modo, dá continuidade e desenvolvimento ao discurso sobre o Estilo de Quatremère de Quincy - cujos escritos eram do conhecimento de Semper e que inclusive por vezes mencionaos em suas publicações - no sentido de reconhecer o condicionamento dos artefatos a fatores particulares e com isso o aspecto relativo deste conceito. É nesse sentido que se pode compreender a proposta semperiana de uma teoria empírica da arte para referir-se à teorização do Estilo. ${ }^{404}$ Isto porque o autor não associa Estilo a apriorismos conceituais - como fora com os gêneros clássicos de construção - mas sim a fatos empíricos, originados em experiências diversas, que logicamente variam de acordo com as circunstâncias. Esta argumentação é sustentada já em seu discurso da origem da Arquitetura, na medida em que a cabana primitiva é referenciada pelo autor mediante exemplares reais, pautados na etnologia, não em algum modelo natural, como sustentava Laugier, por exemplo.

As variáveis ou fatores do Estilo são também apontados por Semper como "coeficientes", termo que ele busca nas ciências naturais. Ao longo do século XIX, a incipiente construção de muitos campos científicos do conhecimento, como a Arquitetura, se fiou muitas vezes em fundamentos das ciências naturais, como uma estratégia de conferir certo estatuto de cientificidade e de se firmar como um conhecimento fundado na razão. Na teorização do Estilo em Semper, isto é observado também na sua proposição de uma equação que serviria como analogia matemática para o que ele compreendia do conceito. Trata-se da fórmula $\mathrm{U}=\mathrm{C}(\mathrm{x}, \mathrm{y}, \mathrm{z}, \mathrm{t}, \mathrm{v}, \mathrm{w} \ldots),{ }^{405}$ na qual $\mathrm{U}$ seria a obra artística, de arte decorativa ou Arquitetura, ou, como o autor coloca, "o resultado geral". ${ }^{406}$ Já as

\footnotetext{
403"...the climate and physical constitution of a country, the political and religious institutions of a nation, the person or the corporation by whom a work is ordered, the place for which it is destined, and the Occasion on which it was produced. Finally also the individual personality of the artist." SEMPER, London lecture of November $11 \ldots$, op.cit., p.12. ${ }^{404}$ Conferir nota 364.

405 Curiosamente, quanto a esta equação, há um fato que deve ser levado em conta, que é justamente a sua ausência na publicação Der Stil (1860 e 1863).

406"...the general result...". SEMPER, For some months I had the honour to read in this room a paper..., Manuscrito n.124, Semperarchiv an der ETH Zürich, 1853, fol.5.
} 
letras $x, y, z, t, v, w$... seriam os diferentes coeficientes que atuam sobre a obra, e C seria a "função" ou o modo a partir do qual os coeficientes trabalham. ${ }^{407}$

A descrição de C como "função" não é casual, refere-se aos usos e propósitos dos objetos ou das obras, ou seja, corresponde a necessidades práticas humanas e Semper acredita serem estas invariáveis, ou seja, "as mesmas em todos os tempos e sob toda circunstância". 408 Trata-se, pois, de leis fixas, ahistóricas, ao contrário dos coeficientes, que podem variar em termos de localização, clima, destinatário, personalidade do artista, entre outros. Neste sentido, C é o elemento determinante para o resultado final, pois é a partir dele que os outros itens operam e, com isso, qualquer alteração de $C$ confere um resultado completamente distinto. Assim Semper descreve a relação entre os elementos dessa fórmula:

logo que um ou alguns destes coeficientes varia, o resultado deve variar do mesmo modo, se $x$ se torna $(x+a)$, o resultado será bastante diferente daquele que nós chamamos agora $\mathrm{U}$; mas ele permanecerá, no princípio, idêntico ao último, estando conectado a ele por uma relação comum a qual é expressada pela letra C. Do mesmo modo, se x, y, z, t, etc., permanecem os mesmos, mas se $\mathrm{C}$ muda, então $U$ mudará de um modo diferente a antes. Ele será fundamentalmente diferente daquilo que era antes, apesar dos coeficientes $x, y, z, t, v$, etc., não terem sofrido mudança alguma. ${ }^{409}$

Ao se fiar em pressupostos das ciências naturais para teorizar um tema tão caro a sua época, Semper procura critérios mais objetivos de julgamento e criação artística e maiores garantias de previsibilidade para as produções contemporâneas, uma vez que "onde o resultado não mostra modificações que correspondem aos elementos modificados que constituem uma função, aí ele está falso e faltando em qualidade". ${ }^{410}$ A garantia da qualidade subentendida na fórmula estava no fato de esta função matemática, conforme explica Mari

\footnotetext{
407 Id. Ibid.

408 "...the same at all times and under every circunstance". Ibidem, fol.6.

409 "As soon as one or some of these coefficients vary, the result must vary likewise, if $x$ becomes $(x+a)$, the result will be quite a different one from that, which we call now $U$; but it will, in the principle, remain identical to the last, being connected with it by a common relation which is expressed by the letter $C$. Likewise, if $x, y, z$, t, etc. remain the same but if $C$ changes, then $U$ will change in an other manner than before. It will be fundamentally different from what it was before, although the coefficients $x, y, z, t$, $v$, etc., have undergone no change". Ibidem, fol.5.

410 "... where the result does not show modifications that correspond to the changed elements making up a function, there it is false and lacking in quality...". SEMPER, Gottfried. The attributes of formal beauty, op.cit., p. 241.
} 
Hvattum, contribuir para "determinar a correta ou incorreta correspondência entre uma obra de arte e suas origens". 411

Essa correspondência com as origens deve ser entendida em um sentido amplo, como uma correspondência com todos os fatores implicados no processo de tornar-se um fenômeno, daí não ser incorreto, acredita Semper, "falar de um Estilo em madeira, um Estilo em tijolo, um Estilo em cantaria, e por aí vai", ${ }^{412}$ assim como de um "Estilo Chinês, Estilo Indiano, Estilo de Luís XIV, Estilo de Rafael, Estilo Eclesiástico, Estilo Rural, etc."413 Trata-se de expressões usadas na linguagem comum que, segundo ele, apesar de aparentemente muitas vezes apontarem para concepções distintas, indicam certa intuição de suas correlações, como, por exemplo, um tratamento semelhante dado a obras de mesma localidade, de mesmo material, para um mesmo comitente, de um mesmo artífice, entre outros fatores que são enfatizados na obra. ${ }^{414}$

Mas mais importante que os fatores isolados é a correspondência com o propósito mais geral da obra, ou, consoante expõe Semper, com seu assunto, ideia, tema ou matéria. ${ }^{415} \mathrm{O}$ tema está acima dos fatores, ele motiva-os e é o que de certo modo define os limites do Estilo. Trata-se, aqui, como se pode notar, do significado maior, mais amplo da obra, que toda obra artística com Estilo deveria explicitar e que, conforme o autor, refere-se, de modos variados, ao "homem em todas as suas relações e conexões com o mundo externo", ${ }^{416}$ ou seja, o homem como um indivíduo, descolado da condição de natureza e ele em suas diversas formas de coletividade. E, se para Semper, nos monumentos arquitetônicos é o Ornamento e todo o revestimento decorativo aquilo que

\footnotetext{
411 "...to determine the correct or incorrect correspondence between an artwork and its origins...". HVATTUM, Gottfried Semper and the problem of historicism, op.cit., p.109.

412"So darf man von einem Holzstyle, Backsteinstyle, Quaderstyle u.s.w. sprechen". SEMPER, Über Baustyle, op.cit., p.12.

413“...Chinese Style, Indian Style, Style of Louis XIV, Style of Rafael, Ecclesiastical Style, Rural Style, etc.". SEMPER, London lecture of November 11, 1853, op.cit., p.12.

414 SEMPER, The attributes of formal beauty, op.cit.

415 Em Über Baustyle, Semper atentou para o duplo sentido desta última palavra - Stoff, em língua alemã, que pode ser matéria (material) no sentido físico ou no sentido de assunto (tema) - e a importância de ambos sentidos para sua teoria do estilo. Após explicar que toda obra deve exibir o "material enquanto matéria física" em sua aparência, ele prossegue afirmando que "entretanto, sob [o termo] matéria entendese ainda algo maior, a saber, a tarefa, o tema para a utilização artística". Tradução nossa de "Aber unter Stoff versteht man noch etwas Höheres, nämlich die Aufgabe, das Thema zur künstlerischen Verwerthung". SEMPER, Über Baustyle, op.cit., p.12.

416 “...den Menschen in allen seinen Verhältnissen und Beziehungen zur Aussenwelt...” Ibidem, p.12.
} 
evidencia o tema principal desta arte, ou seja, a relação do homem com o corpo social coletivo, o Ornamento se mostra em Semper como sinônimo de Estilo. ${ }^{417}$

A importância da correspondência ao propósito maior da obra é destacada na definição do termo Estilo pelo teórico: "Estilo é o evidente destaque da ideia básica em significado artístico e de todos coeficientes internos e externos, os quais, por sua encarnação em uma obra de arte, influenciaram-na de modo modificador". ${ }^{418}$ Estilo seria este acordo entre forma e o conteúdo; ${ }^{419}$ e este destaque dado à ideia no discurso de Semper confere maior importância ao artista, a sua personalidade e vontade individual - o fator mais importante do Estilo, a quem Semper dirige sua proposta de "estética prática" do Der Stil - na harmonização destes dois itens:

portanto, a livre vontade do espírito humano criativo é tomada em primeiro lugar como o fator mais importante na questão do surgimento dos estilos arquitetônicos, a qual [livre vontade] deve se mover livremente em suas criações dentro de determinadas leis maiores da tradição, da demanda e da necessidade, mas se apropria destas leis mediante sua interpretação e utilização livre e objetiva e, por sua vez, as faz subserviente. ${ }^{420}$

Nota-se que há similitudes entre o conceito semperiano de Estilo e aquele tradicional associado à Retórica antiga, como Mallgrave sugere. Conforme este autor,

assim como o estilo para o orador ou compositor localiza-se na exploração formal de um dado tema através de dispositivos ornamentais e harmônicos, também o estilo na arquitetura reside no artista compreender e solicitar as formas e detalhes adequados para seus motivos ${ }^{421}$

Caso o artista não seja bem-sucedido nesta tarefa, o resutado final é deficiente, ou melhor, a obra é carente de Estilo: "ausência de estilo é, então,

\footnotetext{
417 Joseph Rykwert, ao comparar Semper e Adolf Loos, sustenta que "seguindo a Gottfried Semper [...], Loos iguala estilo a ornamento..." RYKWERT, A casa de Adão no paraíso, op.cit., p.23.

418 "Styl ist das zu künstlerischer Bedeutung erhobene Hervortreten der Grundidee und aller inneren und äusseren Coefficienten, die bei der Verkörperung derselben in einem Kunstwerke modificirend einwirkten". SEMPER, Wissenschaft, Industrie und Kunst, op.cit., p.15.

419 MALLGRAVE, The idea of style, op.cit.

420 "Daher kommt der freie Wille des schöpferischen Menschengeistes als wichtigester Faktor bei der Frage des Entstehens der Baustyle in erster Linie in Betracht, der freilich bei seinem Schaffen sich innerhalb gewisser höherer Gesetze des Ueberlieferten, des Erforderlichen und der Nothwendigkeit bewegen muss, aber sich diese durch freie objective Auffassung und Verwerthung aneignet und gleichsam dienstbar macht'. SEMPER, Über Baustyle, op.cit, p.10, colchetes nossos.

421 "Just as style for the orator or composer lay in the formal exploitation of a given theme through ornamental and harmonic devices, so style in architecture resides in the artist understanding and soliciting the proper forms and details for his motives". MALLGRAVE, The idea of style, op.cit., p.346.
} 
segundo esta definição, a expressão para as falhas de uma obra, que surgem do descuido na exploração estética dos meios apresentados para sua conclusão". ${ }^{422}$

Estilo, pode-se dizer, é um atributo qualitativo do artefato, de responsabilidade do artífice. Como esclarece Semper em outro local, ele é

a quintessência daquelas qualidades de uma obra de arte que vêm à tona quando o artista sabe e observa as limitações impostas sobre sua tarefa pelo caráter particular de todos os coeficientes contribuidores e, ao mesmo tempo, leva em consideração e dá ênfase artística a tudo que, dentro destas limitações, estes coeficientes contribuidores oferecem, desde que isto sirva ao propósito da tarefa. ${ }^{423}$

A ênfase artística necessária para evidenciar o Estilo seria um "adequado vestido arquitetônico", 424 aquilo que se dá a ver na obra de arte, aquilo que é visível, a aparência e que, segundo Semper, o artífice confere à obra mediante sua ornamentação. Mas para escolher este vestido arquitetônico, esse artífice teria que compreender os Ornamentos de sua cultura e o processo do tornar-se do qual eles resultaram, sobretudo em termos de forma e de material.

\subsection{O Ornamento é a linguagem do Estilo}

Semper sustenta que "a arte tem sua linguagem própria"425 e esta é formada pelos tipos formais, os quais são fundamentalmente simbólicos para 0 autor. Isto porque estes tipos são a reificação de motivos ou ideias simbólicas que correspondem a gestos ou procedimentos de fabricação artística, ou seja, aos propósitos mais fundamentais. E os motivos primordiais, originários de toda fábrica artística, eram, para o autor, os Ornamentos têxteis.

\footnotetext{
422“Styllosigkeit ist dann nach dieser Definition der Ausdruck für die Mängel eines Werkes, welche aus der Unbeholfenheit in ästhetischer Verwerthung der gebotenen Mittel zu seiner Vollendung entstehen". SEMPER, Wissenschaft, Industrie und Kunst, op.cit., p.15.

423 "...the quintessence of those qualities of a work of art that come to the fore when the artist knows and observes the limitations imposed on his task by the particular character of all contributary coefficients and, at the same time, takes into account and gives artistic emphasis to everything that, within these limitations, these contributary coefficients offer, provided this will serve the purpose of the task". SEMPER, The attributes of formal beauty, op.cit., p.243, grifos do autor.

424 “...geeignete Architektonische Kleid...”. SEMPER, Über Baustyle, op.cit., p.31.

425 "Die Kunst hat ihre besondere Sprache..." SEMPER, Der Stil, vol. I, op.cit., p.1.
} 
Por corresponderem a necessidades fundamentais do homem necessidades de cunho material e também estético -, os motivos originários são ahistóricos. Ou seja, em todos os tempos e lugares, as ideias fabricadoras originárias são as mesmas para todos os indivíduos, sobretudo para os indivíduos primitivos, que estavam mais próximos do estado de natureza. Isto se deve à crença de Semper acerca da analogia entre as formas da arte e as formas da natureza, pois a arte segue as leis do universo, reproduzindo o modo pelo qual a natureza cria. ${ }^{426}$

As leis da natureza eram as responsáveis por toda a variedade formal no universo a partir de poucas formas básicas; e o mesmo ocorria com a arte:

tal como a natureza em sua infinita abundância é, pois, extremamente econômica em seus motivos, como se mostra uma permanente repetição em suas formas básicas, como ela modifica milhares de vezes de acordo com o estágio formativo das criaturas e com as condições variadas de suas existências, [...] como a natureza possui sua história evolutiva, dentro da qual os motivos antigos novamente se insinuam em toda nova formação, do mesmo modo estão sujeitos à arte somente poucas formas normais e tipos, os quais derivam da mais antiga tradição; eles reaparecem constantemente, todavia oferecem uma variedade infinita, e como os tipos da natureza eles têm sua própria história. ${ }^{427}$

Logo, assim como a natureza, "a arte não inventa nada", ${ }^{428}$ pois seus motivos, sendo os mesmos desde o começo da criação, assim permaneciam. 0 que Ihes ocorria era que tinham sua continuidade histórica assegurada em virtude de reinterpretações sofridas pelos tipos artísticos nas diversas culturas. Originariamente, os indivíduos primitivos, guiados por seu instinto artístico, teriam reproduzido e adaptado as formas da natureza em atendimento a suas necessidades ou propósitos. ${ }^{429}$ As gavinhas de plantas trepadeiras, por exemplo, que na natureza são responsáveis pela ligação da planta a outras plantas ou a corpos vizinhos, teriam inspirado o motivo do adorno de pescoço, os colares

\footnotetext{
426 Conferir nota 273.

427"So wie nämlich die Natur bei ihrer unendlichen Fülle doch in ihren Motiven höchst sparsam ist, wie sich eine stetige Wiederholung in ihren Grundformen zeigt, wie aber diese nach den Bildungsstufen der Geschöpfe und nach ihren verschiedenen Daseinsbedingungen tausendfach modificirt, [...] wie die Natur ihre Entwickelungsgeschichte hat, innerhalb welcher die alten Motive bei jeder Neugestaltung wieder durchblicken, eben so liegen auch der Kunst nur wenige Normalformen und Typen unter, die aus urältester Tradition stammen, in stetem Wiederhervortreten denoch eine unendliche Mannigfaltigkeit darbieten, und gleich jenen Naturtypen ihre Geschichte haben". SEMPER, Der Stil, v.I, op.cit., p.VI.

428 "[...in Wahrheit,] die Kunst erfindet nichts...". SEMPER, Der Stil, v.II, op.cit., p.91, grifo do autor. 429 lbidem.
} 
têxteis - que, por exemplo, evidenciam a ligação da cabeça com o resto do corpo -, ou qualquer outra forma de ornamento linear têxtil. E, na história da humanidade, à medida que novas necessidades foram surgindo, novas adequações e interpretações foram feitas.

Outro exemplo de adaptação das formas da natureza seria o caso dos artefatos cerâmicos - vasos, tigelas, colheres, entre outros -, os quais, de acordo com 0 autor, diferentemente do artefato têxtil que tinha essencialmente 0 propósito de ligação, resumiam-se em quatro propósitos principais, a saber, conter, recolher, encher e verter líquidos. A eles era associada a forma do ovo, que era uma forma natural representante da mais pura expressão da idéia de conter, ou seja, era um motivo simbólico de uma espécie de reservatório. De acordo com Semper, para o indivíduo utilizá-lo como reservatório, ele necessitou adaptar sua forma, como fazer uma abertura e talvez achatá-lo em sua parte inferior para que ele pudesse servir de recipiente, inserir uma alça, um bico, e por vezes até uma base para atender às diferentes necessidades. ${ }^{430}$ Raciocínio de adaptação semelhante teria ocorrido com os artefatos das outras técnicas, carpintaria e estereotomia. ${ }^{431}$

Nota-se nessa reflexão que há um esforço do autor, mediante comparação e analogia, em associar as formas históricas às formas naturais, investindo ambas de um sentido simbólico que tem como fundamento um propósito a elas associado. Tal procedimento comparativo de Semper teve como referência o trabalho do naturalista francês Georges Cuvier (1769-1832), quem, na primeira metade do século XIX, procurou compreender como se organizavam biologicamente tanto os seres vivos de sua época quanto aqueles já extintos, mediante um método de classificação natural.

Em uma de suas estadias em Paris, Semper frequentou o Jardin des Plantes, parte do Muséum national d'histoire naturelle, no qual pode presenciar

\footnotetext{
430 lbidem.

431 Segundo esclarece Quitzsch "apesar da categoria do belo ter seu fundamento último nas formas e em suas leis, isso não significa que a arte deva imitar totalmente a natureza. Não pode fazê-lo, em primeiro lugar, nas formas individuais. Não se trata da cega imitação da natureza, mas sim da contemplação das leis que constituem o fundamento de suas formas: isto é o que espera o autor, pelo que o artista deve conhecer tais leis, mas também criar a forma artística dentro dos limites atribuídos a ele, evitando a imitação esquemática e cega...”. Tradução de: “...benché le categorie del bello abbiano il loro fondamento ultimo nelle forme naturali e nelle loro leggi, ciò non significa che l'arte debba imitare in tutto la natura. Non può farlo, in primo luogo, nelle singole forme. Non la cieca imitazione della natura, ma la contemplazione delle leggi che costituiscono il fondamento delle sue forme: questo auspica l'autore, per il quale l'artista deve conoscere tali leggi, ma anche creare la forma artística entro i limiti a lui assegnati, evitando schematiche e cieche imitazione...". QUITZSCH, Heinz. La visione estetica di Semper, op.cit., pp.91-92.
} 
uma exposição de Cuvier em que remanescentes fósseis de animais eram exibidos comparativamente em séries ao lado de esqueletos dos tempos contemporâneos. ${ }^{432} \mathrm{Em}$ sua proposta metodológica, o naturalista estabelecia uma matriz comparativa, por exemplo, de órgãos de animais - existentes ou extintos - de uma mesma espécie, em que o princípio comparativo estava na função de cada órgão e suas partes. Antes de identificações formais, é a função comum dos órgãos que agrupa as semelhanças, a qual, mesmo não apresentando elementos visivelmente idênticos, evidencia a repetição e variabilidade nas criações da natureza. ${ }^{433}$

Do conteúdo da exposição, Semper concluiu que

nós vemos o mesmo esqueleto repetindo-se continuamente, mas com inumeráveis variedades, modificadas por desenvolvimentos graduais dos indivíduos e pelas condições de existência que eles têm que preencher. Ali nós vemos algumas partes deixadas de fora, outras partes somente indicadas, as quais são extremamente desenvolvidas em outros indivíduos. ${ }^{434}$

Isto reforçou a crença de Semper de que as leis que orientam os fenômenos naturais também podem ser percebidas nas produções artísticas. Para ele, assim como no mundo animal, também na História da Arte era evidente certa repetição e diferenciação em suas formas. Isto Ihe foi sugerido por esta metolodogia comparativa, usual no campo científico oitocentista, e que, no caso das incipientes "ciências dos homens" avaliava os fenômenos históricos antes em suas relações-padrão do que em sua particularidade histórica, o que, podese dizer, tomava manifestações temporalmente distintas como contemporâneas. Ao privilegiar a busca de determinados padrões, tem-se uma análise mais

\footnotetext{
432 MALLGRAVE, Gottfried semper: architect of the nineteenth century, op.cit.

${ }^{433}$ Conforme coloca Michel Foucault, "a partir de Cuvier, a função, definida sob a forma não-perceptível do efeito a atingir, vai servir de meio-termo constante e permitir relacionar um a outro conjuntos desprovidos da menor identidade visível. Aquilo que, para o olhar clássico, não passava de puras e simples diferenças justapostas a identidades, deve agora ser ordenado e pensado a partir de uma homogeneidade funcional que o suporta em segredo". FOUCAULT, Michel. As palavras e as coisas. Uma arqueologia das ciências humanas. Trad. Salma Tannus Muchail. São Paulo: Martins Fontes, 2000, pp.363-364.

434"We see the same skeleton repeating itself continually, but with innumerable varieties, modified by gradual developments of the individuals and by the conditions of existence they had to fulfill. There we see some parts left out, some other parts only indicated, which are exceedingly developed on other individuals". SEMPER, For some months I had the honour to read in this room a paper..., Manuscrito n.124, Semperarchiv an der ETH Zürich, 1853, fol.4.
} 
objetiva, apropriada aos pressupostos de racionalidade da ciência, no entanto, a historicidade própria a cada fenômeno fica em segundo plano. 435

Outro campo em que os estudos comparativos avançavam na época de Semper era o das investigações das línguas, e Semper observa aí um caminho que deve ser percorrido também pela arte de seu tempo:

como a mais recente pesquisa linguística está empenhada em mostrar as relações de parentesco dos idiomas humanos uns com os outros, em perseguir as palavras em seu percurso transformativo no decorrer do tempo e conduzi-las até um ou mais pontos nos quais elas se encontram em formas primordiais comuns [..] exatamente assim se justifica um esforço análogo no campo da pesquisa artística, o qual dedica atenção à evolução das formas artísticas desde seus embriões e raízes a suas transferências e ramificações, aos quais elas [as formas] certamente pertencem. ${ }^{436}$

Assim como o orador enriquece seu discurso com o estudo das origens e modificações dos vocábulos, podendo usar palavras não usuais, antigas ou raras, por exemplo, também o arquiteto pode lançar mão de semelhante recurso nas obras arquitetônicas, estudando a linguagem da arte e usando-a para transformar os tipos antigos: 437

o público interessado e a maioria dos arquitetos atuantes seguem estas tradições mais inconscientemente, mas aquele arquiteto que reconhece os símbolos antigos de sua língua em seu valor primordial e que tem em conta o modo como que eles, com a própria arte, historicamente se transformaram em forma e significado, tem a mesma vantagem que a pesquisa comparativa da linguagem e o estudo do parentesco primordial das línguas concedem ao orador atual. ${ }^{438}$

\footnotetext{
435 Para maior aprofundamento sobre o método comparativo de Semper e suas relações com os métodos das ciências naturais no século XIX, conferir HVATTUM, Mari. Gottfried Semper and the problem of historicism, op.cit., pp.114-145.

436"Wie nun die neueste Sprachforschung bestrebt ist, die verwandtschaftlichen Beziehungen der menschlichen Idiome zu einander nachzuweisen, die einzelnen Wörter auf ihrem Gange der Umbildung in dem Laufe rückwärts zu verfolgen und sie auf einen oder mehrere Punkte zurückzuführen, woselbst sie in gemeinsamen Urformen einander begegnen [...] eben so lässt sich ein analoges Bestreben auf dem Felde der Kunstforschung rechtfertigen, welches der Entwicklung der Kunstformen aus ihren Keimen und Wurzeln, ihre Uebergängen und Verzweigungen diejenige Aufmerksamkeit widmet, die ihnen ohne Zweifel gebührf'. SEMPER, Der Stil, vol.I, op.cit., pp.1-2, colchetes nossos.

437 Com sua teoria dos motivos e tipos artísticos, Semper, de certo modo, está propondo um novo léxico ornamental para a Arquitetura e para as artes decorativas. Este novo vocabulário não consistia exatamente na proposição de algo novo; tratava-se antes da reinterpretação dos tipos artísticos antigos, os quais, segundo o autor, passavam por um processo de "desintegração" [Zersetzung] devido à perda da vitalidade e legitimidade da iconografia clássica tradicional. SEMPER, Wissenschaft, Industrie und Kunst, op.cit., p.27. 438 "Das beschauende Publikum und die Mehrzahl der ausführenden Architecten folgt diesen Traditionen mehr unbewussterweise, aber denselben Vorteil, den die vergleichende Sprachforschung und das Studium der Urverwandtschaften der Sprachen dem heutigen Redekünstler gewähren, hat derjenige Baukünstler in seiner Kunst voraus, der die ältesten Symbole seiner Sprache in ihrer ursprünglichsten Bedeutung erkennt
} 
Se na semelhança de traços entre os vocábulos observava-se um parentesco, ou seja, raízes comuns, que permitiam mapear o desenvolvimento das palavras no tempo e no espaço, tal procedimento possibilitava encontrar pistas acerca das significações originárias dos próprios tipos ornamentais, pois

tal como as raízes da linguagem sempre afirmam sua validade e em todas posteriores transformações e alargamentos dos conceitos - os quais se amarram nela - a forma básica novamente evidencia-se, assim também é impossível ao mesmo tempo inventar uma nova palavra para um novo conceito, sem falhar no primeiro objetivo, isto é, o ser compreendido[...]. ${ }^{439}$

Este era o caso, evidente para Semper, do sentido originário têxtil da Arquitetura, que poderia ser comprovado ao se comparar os vocábulos em alemão Wand [parede] e Gewand [vestimenta]. ${ }^{440}$ A semelhança entre ambos atestava o propósito essencial da parede, o de vestir ou revestir - quando era 0 caso do revestimento. Outras semelhanças estão entre as palavras Zaun [cerca] e Saum [bainha], assim como entre Naht [costura] e Not [necessidade].

No entanto, se na teorização de Semper, como coloca Michael Gnehm, "a função vem das palavras às formas", ${ }^{441}$ nota-se que a semelhança de traços não é necessariamente formal. Gnehm sustenta que Semper empreende uma interpretação fundamentada em uma circularidade de conceitos entre as palavras e a linguagem que surge dos sons, não exatamente dos signos escritos. ${ }^{442}$ Para esse autor, em Semper, "a etimologia se efetua com base na linguagem oral". 443

No Der Stil, o autor apresenta alguns dos principais motivos ornamentais que ele acredita terem impulsionado os principais tipos nas diferentes culturas. Tem-se como exemplos o cordão, a faixa, a costura e a bainha. O cordão é

\footnotetext{
und sich von der Weise Rechenschaft ablegt, wie sie, mit der Kunst selbst, sich geschichtlich in Form und Bedeutung umwandelten". SEMPER, Der Stil, v.l, op.cit., p.7.

439 "So wie die Sprachwurzeln ihre Geltung immer behaupten und bei allen späteren Umgestaltungen und Erweiterungen der Begriffe, die sich an sie knüpfen, der Grundform nach wieder hervortreten, wie es unmöglich ist, für einen neuen Begriff zugleich ein ganz neues Wort zu erfinden, ohne den ersten Zweck zu verfehlen, nämlich verstanden zu werden". Id.Ibid., pp.6-7.

440"A palavra alemã Wand, paries, dá a reconhecer sua origem. Os termos Wand e Gewand correspondem a uma mesma raiz. Eles indicam o material trançado, que formava a parede". Tradução de:"Der deutsche Ausdruck Wand, paries, giebt seinen Ursprung zu erkennen.Die Ausdrücke Wand und Gewand sind Einer Wurzel entsprossen [sic]. Sie bezeichnen den gewebten oder gewirkten Stoff, der die Wand bildete". SEMPER, Die vier Elemente, op.cit., p.57, nota de rodapé.

441 "[Klar ist, ] dass diesen Formen die Funktion von Wörtern zukommt...". GNEHM, Michael. Stumme Poesie. Architektur und Sprache bei Gottfried Semper. Zürich: gta Verlag, 2004, p.82.

442 lbidem.

443 “...die Etymologie anhand der Lautsprache vornimmt”. Ibidem, p.91.
} 
formado pela junção rítmica de peças unitárias formando uma ordem eurítmica; na medida em que seus elementos estão unidos e se referenciam a um ponto central, ele expressa o conceito de unir. A faixa, por sua vez, junta partes que não pertencem a ela, ao mesmo tempo em que ela enquadra estas partes, igualmente compondo um arranjo eurrítmico e destacando o centro. A costura e a bainha, para o autor, estão intrinsecamente relacionadas. Das duas, a costura é a que recebe maior destaque por Semper, pois, segundo ele, a relação conceitual e etimológica entre Naht [costura] e Not [necessidade], indicava e legitimava um axioma fundamental da prática artística:

originalmente empregada em vestimentas e coberturas, através de uma associação de idéias muito antiga e mesmo pelo uso lingüístico, ela se tornou o símbolo e a analogia universais para qualquer junção em uma relação firme de superfícies originalmente separadas ${ }^{444}$

A costura é o motivo que melhor evidencia o propósito de unir; ela úne superfícies de mesma natureza, e, diferentemente da faixa, que atúa ao longo do comprimento da superfície, ela age na dimensão da largura, mediante um movimento rítmico da direita para a esquerda, como em zigue-zague. Já a bainha funciona como uma costura e ao mesmo tempo como uma faixa, atuando na largura como costura e longitudinalmente como uma faixa. Ela ainda marca a terminação do trabalho, coroando-o, seja na sua parte superior ou inferior.

O teórico investiga diversos exemplos de tipos ornamentais que ele acredita terem sido originados destes quatro motivos têxteis e, comparativamente, procura mostrar como o propósito deles é o mesmo tanto na Arquitetura, quanto nas artes decorativas e nas vestimentas (figuras 14 a 27).

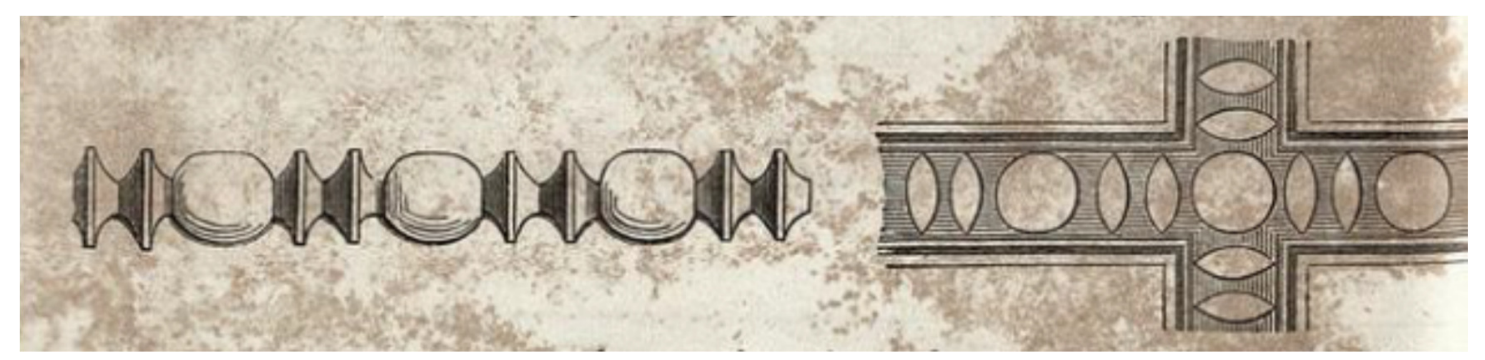

Figura 14 - Cordão de pérolas e nós e sua estilização em uma moldura ornamental. Desenhos de Semper. Fonte SEMPER, Der Stil, vol.I, 1860.

444 “...ursprünglich auf Gewänder und Decken angewendet, durch uralte Begriffsverknüpfung und selbst sprachgebräuchlich das allgemeine Analogon und Symbol jeder Zusammenfügung ursprünglich getheilter Oberflächen zu einem festen Zusammenhange geworden ist'. SEMPER, Der Stil, v.l, op.cit., pp.78-9. 

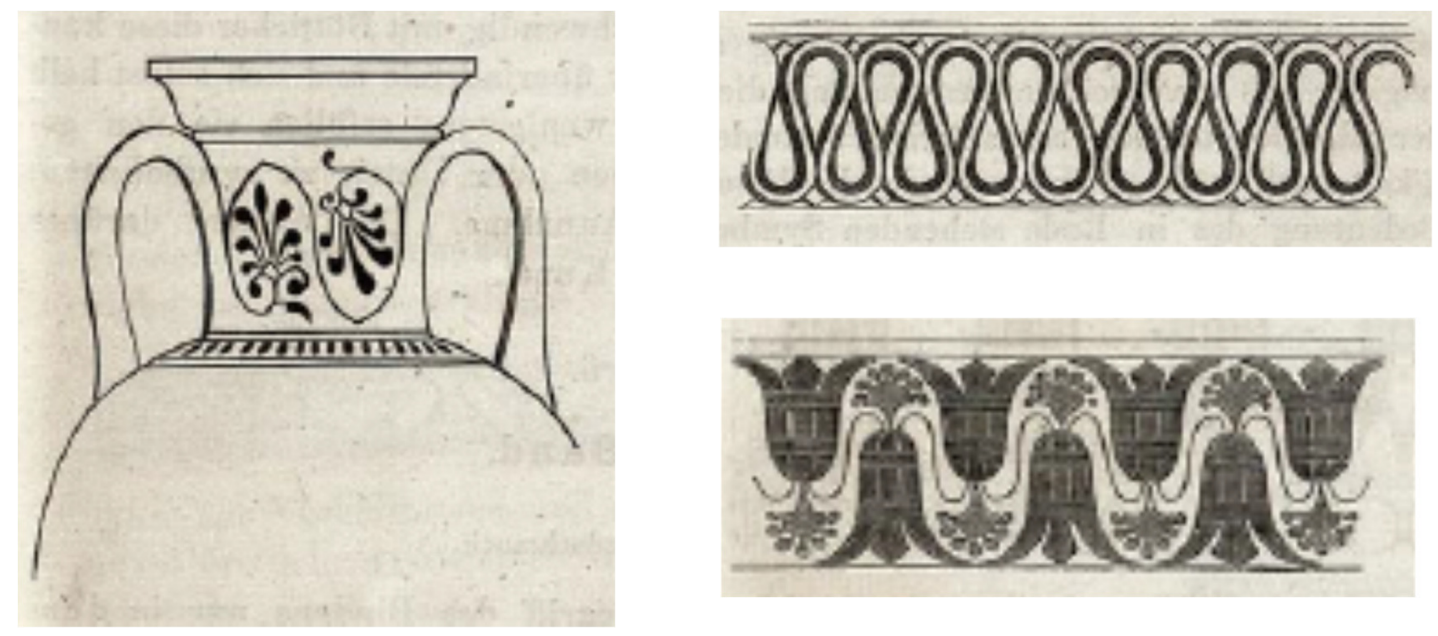

Figuras 15 a 17 - À direita dois tipos de cordões, abaixo uma coroa de flores e acima uma sequência de ondas. À esquerda, um cordão marcando o pescoço de um vaso cerâmico. Desenhos de Semper. Fonte: SEMPER, Der Stil, vol.I, 1860.
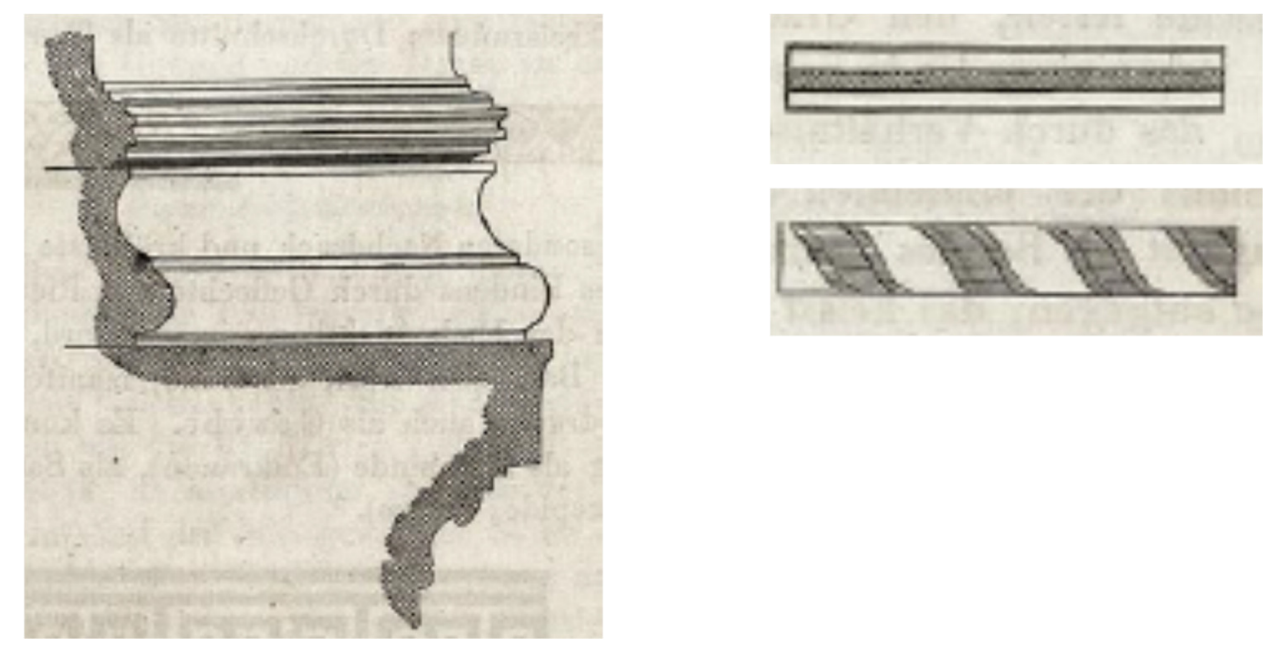

Figuras 18 a 20 - À direita tipos de faixas e à esquerda sua exemplificação nos toros da base jônica. Desenhos de Semper. Fonte: SEMPER, Der Stil, vol.I, 1860.
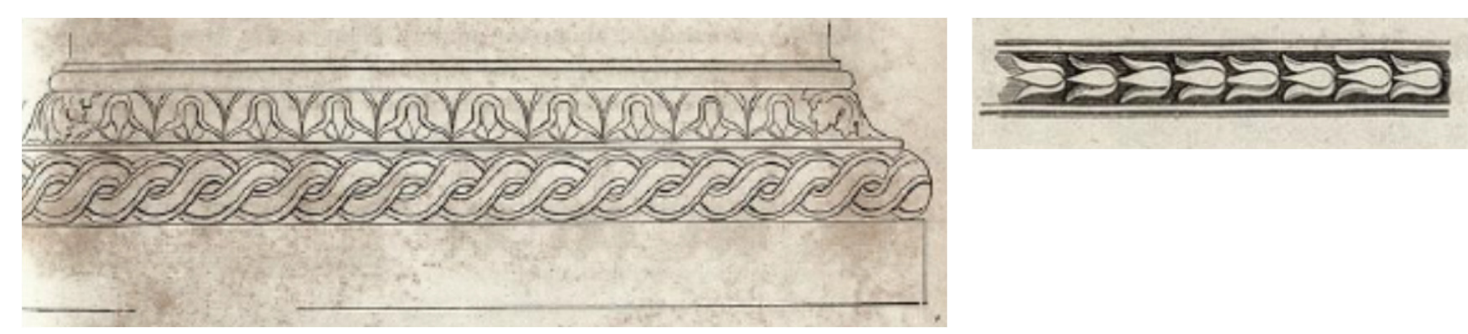

Figuras 21 e 22 - Exemplos de cordões estilizados, usados na arquitetura. Desenhos de Semper. Fonte: SEMPER, Der Stil, vol.I, 1860. 

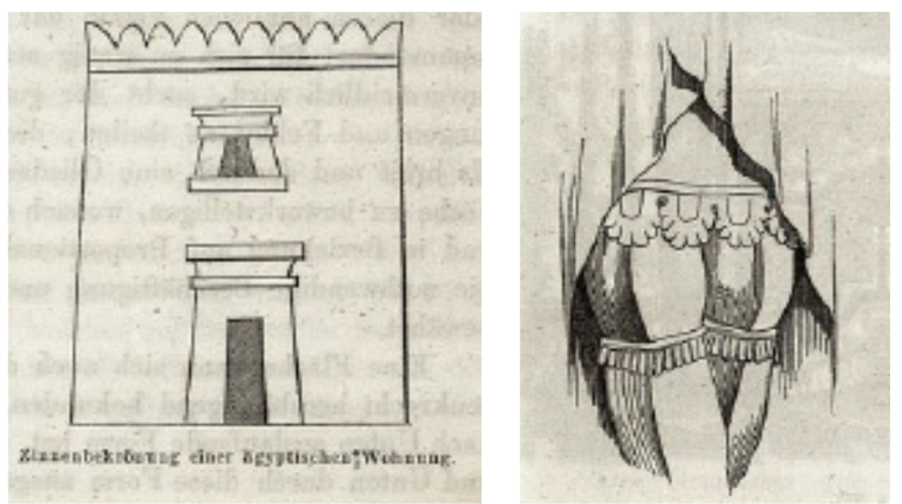

Figuras 23 e 24 - Edificação coroada com ameias e as franjas de uma vestimenta medieval. Desenhos de Semper. Fonte: SEMPER, Der Stil, vol.I, 1860.
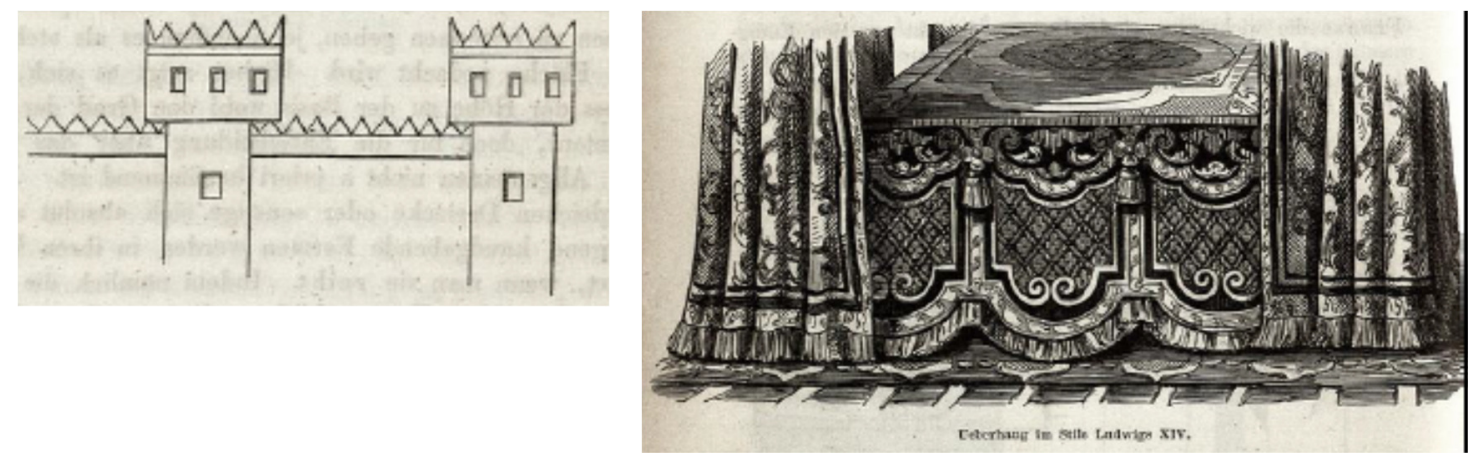

Figuras 25 e 26 - Castelo assírio com ameias e franjas de um dossel estilo Luis XIV. Desenhos de Semper. Fonte: SEMPER, Der Stil, vol.I, 1860.

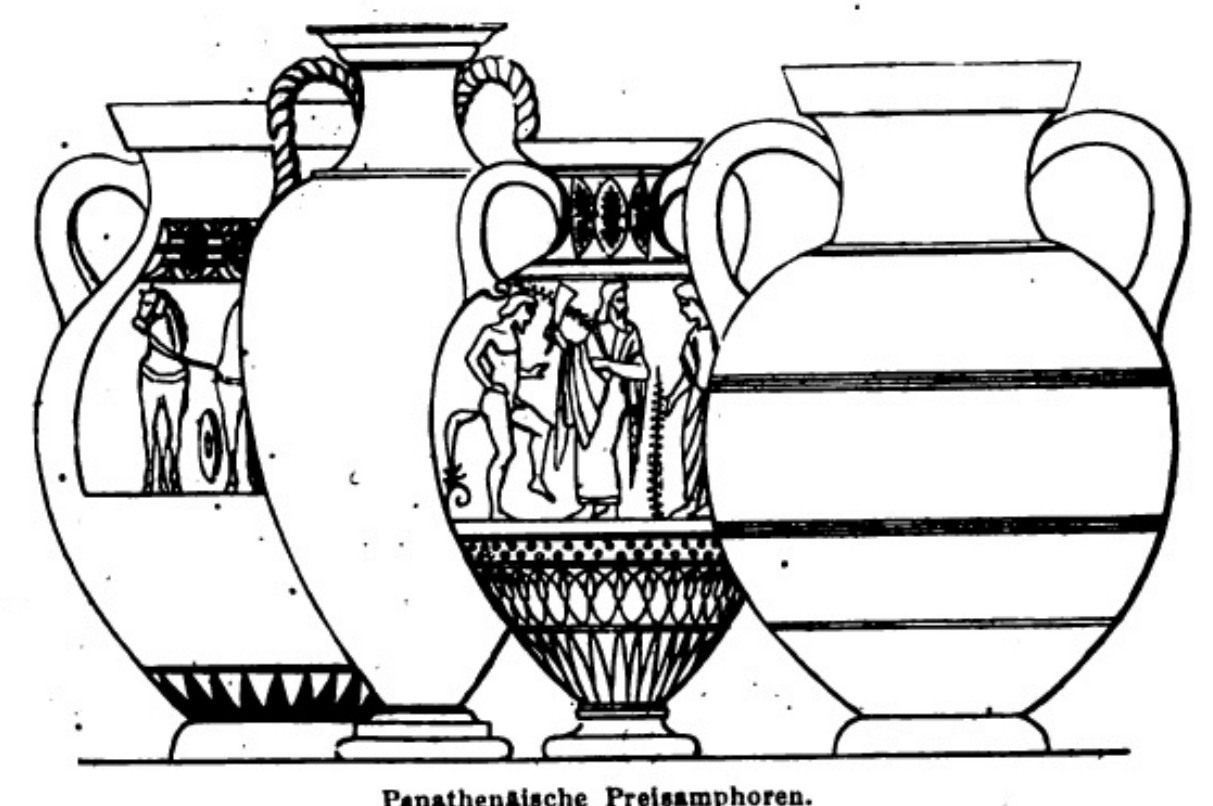

Figura 27 - Anforas das premiações panatenaicas exibindo como decoração cordões e faixas. Desenho de Semper. Fonte: SEMPER, Der Stil, vol.II, 1863. 
Não obstante o evidente - para Semper - contato entre as culturas, o teórico sabe que, o que faz o mesmo motivo aparecer como um tipo semelhante em um mosaico grego e posteriormente um romano, como meandros (figuras 28 e 29), por exemplo, não é simplesmente a transmissão formal dos símbolos, mas também, e principalmente, o domínio e a transmissão da técnica, do trabalho com o material, um dos principais fatores dessa concepção do Estilo. ${ }^{445}$

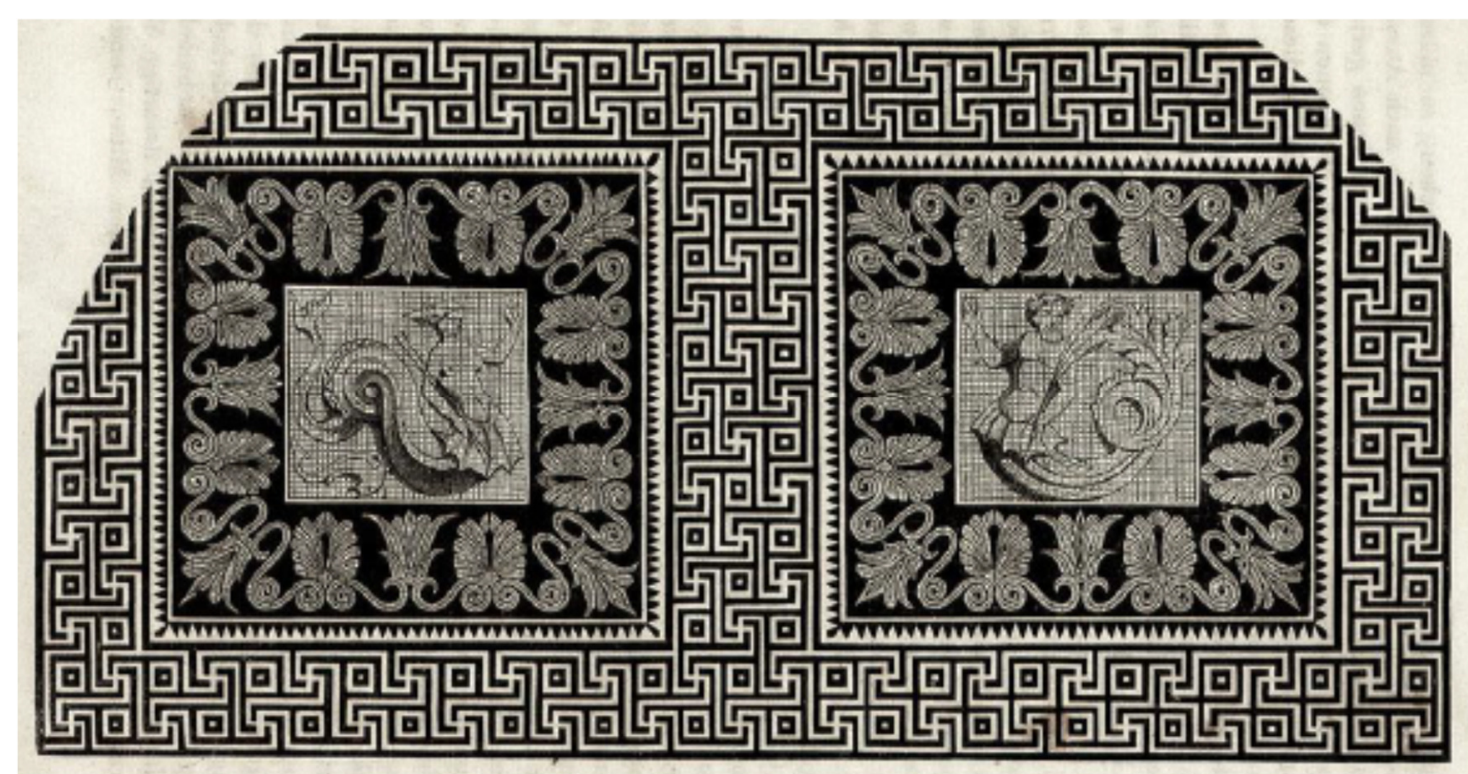

Figura 28 - Representação de piso de mosaico do pronau do templo de Zeus Olímpico em Atenas, com bordas de meandros como sobrevivência da bainha, segundo Semper. Desenho do autor. Fonte: SEMPER, Der Stil, vol.I, 1860.

445 Quanto a isto, é interessante perceber o que afirmou posteriormente o teórico Ernst Cassirer: "Arte e ofício, actividade plástica e habilidade artesanal só se separaram lentamente; e precisamente nos pontos altos do desenvolvimento artístico é que a sua conexão costuma ser particularmente íntima. Nenhum artista pode falar verdadeiramente a sua língua se não a aprendeu antes na relação continuada com o seu material'. Tragédia da cultura. In: SERRÃO, Adriana V. (ed.). Philosophica, n.23, Lisboa, 2004, p.149. Mais adiante, na mesma página, Cassirer afirma o estreito vínculo da técnica com a tradição e estende esta associação igualmente para o mundo das formas: "Cada época toma da anterior determinadas formas e transmite-as à seguinte. A linguagem das formas toma uma firmeza tal que determinados temas permanecem unidos fortemente com certos modos de expressão, a ponto de os encontrarmos sempre de novo nas mesmas formas ou em formas apenas ligeiramente modificadas. Esta "lei de persistência", que é valida para o movimento continuado das formas, constitui um dos factores mais importantes do desenvolvimento artístico...". 


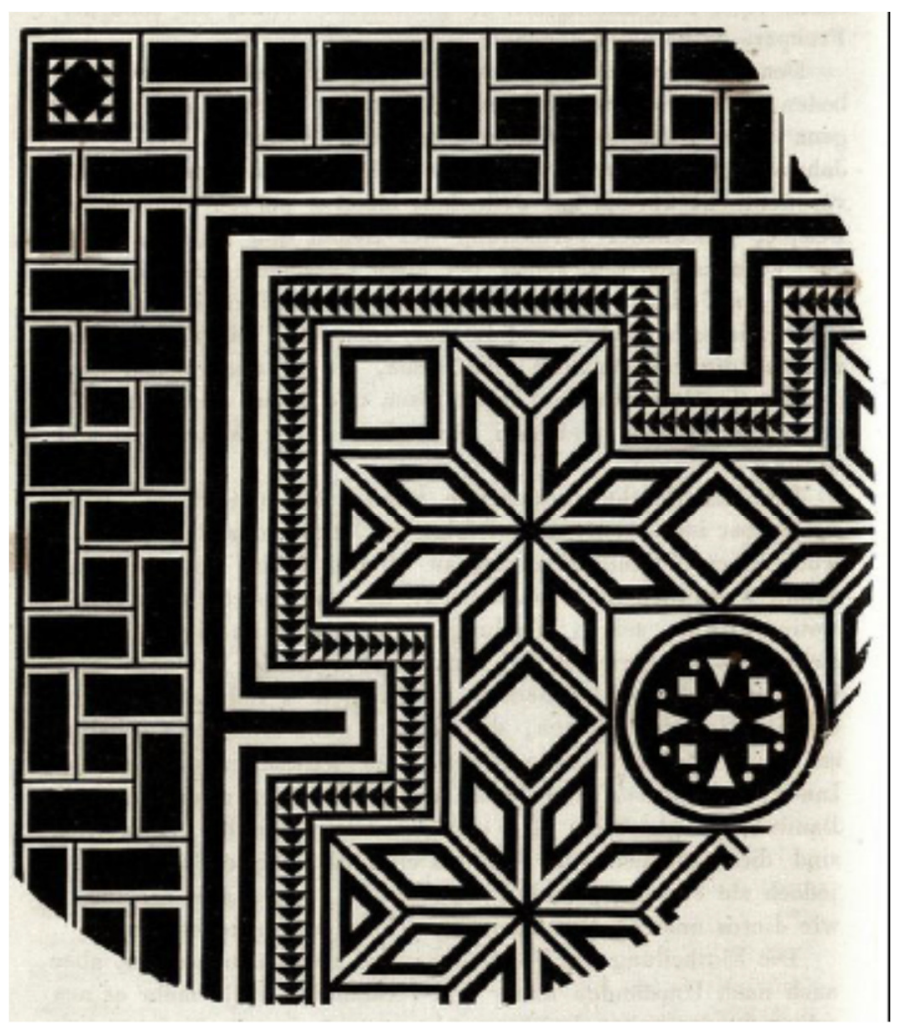

Figura 29 - Representação de um piso de mosaico romano, no qual, segundo Semper, as bordas são um tipo de meandro, e indicam sobrevivência da bainha têxtil. Fonte: SEMPER, Der Stil, vol.I, 1860.

\subsection{A mão, o material e o artifício}

O Estilo para Semper está fundamentalmente atrelado a um saber-fazer

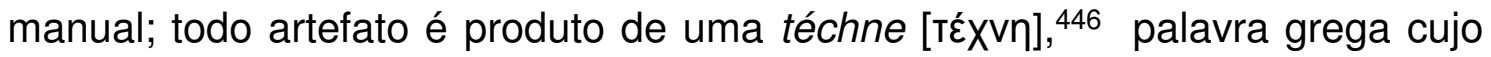
sentido ressoa na etimologia do vocábulo alemão Kunst, ${ }^{447}$ e que evidencia a acepção tradicional do artístico, como já no De Architectura havia sido teorizado. ${ }^{448}$ Daí o fato de Semper criticar a expressão contemporânea "artes técnicas", 449

uma expressão que, através do seu pleonasmo, indica, apropriadamente o suficiente, ou seja, o absurdo das condições artísticas modernas, através do qual um grande abismo,

446 Conferir capítulo 1, nota 51. O filósofo Martin Heidegger, em A origem da obra de arte. (Trad. Idalina Azevedo e Manuel António de Castro. SP: Edições 70, 2010), considera que o sentido do termo como resultado de um "trazer à frente" [hervorbringen] a idéia na mente do artífice, que alcançaria o resultado por meio dos procedimentos para sua execução.

447 Conferir nota 271.

448 Conferir nota 31.

449"technischen Künste”. SEMPER, Der Stil, vol. I, op.cit., p.VII. 
desconhecido dos gregos, separa as chamadas artes menores e as do mesmo modo denominadas artes maiores... ${ }^{450}$

A separação entre artes maiores e artes menores era tão absurda quanto infundada, uma vez que - como sugere seu discurso sobre as origens - "o desenvolvimento das artes práticas e industriais alcançou um alto nível antes da arquitetura como uma arte independente ter sido mesmo pensada," ${ }^{451}$ ou seja, "as artes estavam muito avançadas em sua aplicação para o adorno, armas, implementos e vasos muitos milhares de anos antes dos monumentos serem construídos". ${ }^{452}$ Semper quer dizer com isso que todo artefato, seja ele um objeto utilitário, um Ornamento arquitetônico, uma Arquitetura, ou mesmo uma pintura ou escultura, é não somente derivado de algum tipo de adorno ou objeto de uso $^{453}$ - tendo inclusive tomado emprestado destes os princípios da beleza formal - como também, e principalmente, produto de uma atividade manual associada a um pensamento simbólico.

Nesse sentido, Arquitetura e artes decorativas não possuíam hierarquização entre si; pelo contrário, ambas são identificadas por Semper como fazendo parte da Tectônica, denominação anteriormente explorada por Karl Otfried Müller para referir-se à classe de artefatos em que a criação e a fabricação são contíguas, e nas quais "a ideia artística da obra deva surgir

450 "Ein Ausdruck der durch seinen Pleonasmus die Verkehrtheit der moderne Kunstzustände, wonach eine weite, den Griechen unbekannte, Kluft die sogenannten Kleinkünste und die ebenfalls sogenannten hohen Künste trennt, treffend genug bezeichnet..." Id. Ibid., p.VII, nota 1.

451 "...the development of practical and industrial arts had reached a high level before architecture as an independent art had even been thought of". SEMPER, The Attributes of Formal Beauty, op.cit., p.223.

452 "...the arts were far advanced in their application to adornment, weapons, implements, and vessels many thousands of years before monuments were built". Id.Ibid., p.223.

453 Afirmação que contrariava o pensamento de muitos teóricos contemporâneos. Owen Jones, por exemplo, na primeira proposição de sua Gramática do Ornamento, afirma que "as artes decorativas advêm da arquitetura e devem atendê-la adequadamente". JONES, Owen. A gramática do ornamento, op.cit., p.23. 
naturalmente da definição do propósito ${ }^{454}$ para se ter um sentimento vivo e profundo". 455

A noção de Estilo na Tectônica semperiana aborda e dá ênfase à habilidade manual, pois é o trabalho da mão do artífice em lidar com as características do material e com as técnicas e ferramentas empregadas que reproduzi o procedimento criador da natureza, dando sentido ao artefato. $O$ autor recorre à origem latina do termo Estilo para sustentar essas suas ideias. Estilo, deste modo, vem de stylus, que consistia no "estilete, o instrumento do qual os antigos se serviam para escrever e desenhar"456 em tábuas de cera, que, servindo como metáfora para o conceito, conduz à reflexão de que:

à ferramenta pertence, primeiro, a mão que guia, e um propósito, que conduz esta última. Aqui estão implícitos os momentos técnicos e pessoais do surgimento de uma obra de arte. Então, por exemplo, a cinzelagem do metal requer outro estilo que 0 [tratamento] do gesso. Assim se diz também, por exemplo, que Donatello e Michelangelo são parecidos em estilo, e por aí vai. Ambos estão corretos. Depois pertence à ferramenta e à mão que guia, o material a ser tratado, a ausência de forma a ser recriada em forma. Em primeiro lugar, o material como matéria física, o qual toda obra da arte deve refletir em sua aparência, por assim dizer. Assim o templo grego em mármore, por

${ }^{454}$ A questão do propósito [Zweck; ou finalidade, objetivo] ou adequação ao propósito [Zweckmäßigkeif] possuía no século XIX uma acepção mais ampla que aquilo que no século XX ficou conhecido como função ou funcionalidade. Schinkel usava-os para se referir tanto à distribuição espacial da planta, quanto à escolha e junção dos materiais apropriados à planta ou até à seleção e adequada localização dos Ornamentos. Cf. SCHINKEL, Karl F. Literary Fragments. In: MALLGRAVE, Harry F (ed.). Architectural theory, volume l: an anthology from Vitruvius to 1870. Oxford: Blackwell Publishing, 2006, pp. 401-403. De acordo com Mallgrave (Ibidem), a teoria arquitetônica alemã foi em grande parte conduzida por esta noção e em parte isto se deve às idéias presentes na Crítica da Faculdade do Juízo de Kant (op.cit.). Nesta obra, Kant estabelece dois tipos de beleza, a "beleza livre" e a "beleza dependente". A primeira seria desinteressada, intuída sem um propósito ou objetivo na mente, já a segunda seria aquela para a qual nós trazemos um propósito particular no julgamento. Esta última teria sido compreendida como mais adequada, por exemplo, à construção. Ainda Mallgrave (Ibid., p.398) esclarece que August Schlegel foi um dos que deram continuidade e elaboração a esta noção do propósito, associando-a à Arquitetura. Segundo ele, Schlegel reconhecia que, se a Arquitetura ficasse presa ao propósito, não seria reconhecida como uma arte. O que a caracterizaria como uma arte era a "aparência da adequação ao propósito", no sentido de que ela deveria reproduzir as leis da natureza, como "regularidade, simetria, proporção e as leis físicas e psicológicas da forma (contra a gravidade) ". Esta idéia é muito próxima da que Semper desenvolveu acerca da natureza da Tectônica.

455 “...die Kunstidee des Werks aus seiner Zweckbestimmung für ein lebendiges und tiefes Gefühl natürlich hervorgehen müsse". MÜLLER, Handbuch der Archäologie der Kunst, op.cit., p.11. Na mesma obra (p.10), Tectônica é assim definida pelo autor: "Daqui resultam uma série de artes, as quais dão forma e desenvolvem utensílios, recipientes, edificações e lugares de reunião dos homens, por um lado conforme a determinação do propósito, mas por outro em conformidade com sentimentos e idéias artísticas. Nós chamamos esta série de atividades mistas de Tectônica; seu cume é a Arquitectônica, a qual mais se eleva da necessidade e que pode tornar-se uma potente representação de sentimentos profundos". Tradução de "Hieraus geht eine Reihe von Künsten hervor, welche Geräthe, Gefässe, Wohnungen und Versammlungsorte der Menschen zwar einerseits nach ihrer Zweckbestimmung, aber andrerseits in Gemässheit von Gefühlen und Kunstideen, gestalten und ausbilden. Wir nennen diese Reihe gemischter Thätigkeiten Tektonik; ihr Gipfel ist die Architektonik, welche am meisten vom Bedürfniss sich emporschwingen, und zu einer machtvollen Darstellung tiefer Empfindungen werden kann".

456"Styl ist der Griffel, das Instrument, dessen sich die Alten zum Schreiben und Zeichnen bedienten...". SEMPER, Über Baustyle, op.cit., p.11. 
exemplo, é diferente em estilo do quase idêntico templo grego de pedra porosa. ${ }^{457}$

A mão era a responsável por evidenciar o gesto criador, por deixar registrado o propósito do artefato e, sobretudo, por impor os limites do trato com o material; tais limites ficam evidentes no aspecto final, no tratamento dado, e são precisamente eles que diferenciam o valor simbólico do trabalho com um determinado material do valor simbólico do trabalho com outro material.

Alina Payne esclarece que o papel da mão no conceito de Estilo em Semper difere daquele na noção de Estilo conforme compreendida pela Tradição Clássica a partir de Giorgio Vasari, isto é, como a maneira particular de um artista trabalhar. ${ }^{458}$ Isso porque em Semper, não se trata de uma noção subjetiva, que busca por aspectos da personalidade de quem faz, mas sim, pode-se dizer, de uma antropológica, que aborda o artífice genericamente enquanto indivíduo, ${ }^{459}$ agente criador, que vive uma experiência - que está associada a um aprendizado, a um saber apreendido - e a ela atribui sentidos. Payne afirma que

... o interesse de Semper era coerente com sua declaração de abertura na introdução [do Der Sti], onde ele anunciou que, diferentemente dos historiadores da arte, ele estava procurando analisar o processo artístico, não o produto final. De modo a oferecer uma solução viável para a deterioração angustiante das artes, ele argumentou que a raiz própria do comportamento artístico e seu papel no desenvolvimento da forma tinham que ser explorados - por isso sua ênfase na feitura e em seu agente, a mão do artífice. 460

Essa ênfase na mão do artífice como um dos fatores preponderantes da criação artística ia de encontro às condições artísticas contemporâneas, submetidas aos métodos e inovações da indústria moderna. Em seus escritos, Semper lamenta a depreciação do trabalho de fabricação, não só a divisão das

\footnotetext{
457 "Zu dem Werkzeug gehört aber zunächst die Hand, die es führt, und ein Wille, der letztere leitet. Hier sind also die technischen und persönlichen Momente der Entstehung eines Kunstwerkes angedeutet. So erfordert z.B. das Treiben des Metalles einen andern Styl als das Giessen. So sagt man z.B. auch, Donatello und Michelangelo seien im Styl verwandt, u.s.w. - Beides gleich richtig. Sodann gehört zu dem Werkzeuge und der Hand, die es führt, der zu behandelnde Stoff, das in die Form umzuschaffende Formlose. Zunächst der Stoff als physische Materie, den jedes Werk der Kunst in seinem Erscheinen gleichsam reflektiren soll. So ist z.B. der griechische Marmortempel im Style verschieden von dem sonst nahezu identischen grieschichen Tempel aus Porosstein ". Id.Ibid., pp.11-12.

${ }^{458}$ PAYNE, Alina. From ornament to object, op.cit. 459 Id.lbid.

460"...Semper's interest was consistent with his opening statement in the introduction where he had announced that, unlike art historians, he was seeking to analyze artistic process, not the end product. In order to offer a workable solution to the distressing deterioration of the arts, he argued, the very root of artistic behavior and its role in the development of form had to be explored - hence his emphasis on making and its agent, the artisan's hand'. Ibid., pp.48-49, grifo da autora.
} 
tarefas, como também a depreciação dos materiais por seu tratamento pela máquina, algo que, para o autor, ocasionava um menoscabo do próprio sentido da obra. ${ }^{461}$

Em suas considerações sobre os artefatos industriais da grande exibição londrina de 1851, o teórico surpreende-se com o fato de que "o mais duro pórfiro e granito corta-se como giz, pule-se como cera, [assim como] o marfim é amaciado e pressionado em formas". ${ }^{462}$ Nota-se que se trata de situações em que a máquina e os métodos modernos de fabricação inviabilizam o registro da manipulação da mão e das ferramentas no contato com a matéria, algo que, para o autor, solapa tanto o valor simbólico dos materiais - como, por exemplo, o aspecto de solidez e massividade denotado pelos trabalhos em pedra - , quanto das formas resultantes. ${ }^{463}$ Quanto a isto, Semper questiona:

como devemos tratar o granito agora? É difícil fornecer uma resposta satisfatória para isso! $O$ que se segue será provavelmente que nós deveríamos empregá-lo lá somente onde sua durabilidade é recorrida, e a partir desta última condição depreender as regras para seu tratamento estilístico. ${ }^{464}$

Uma das importantes regras estilísticas encontra-se sugerida nessa úlima frase, a de que a obra "deve ser e parecer como sendo uma consequência lógica e natural da matéria prima". ${ }^{465} \mathrm{O}$ atributo qualitativo de uma obra com Estilo é, antes de tudo, que ela seja tratada adequadamente em relação às propriedades do material utilizado. Segundo Semper, na contemporaneidade, tal princípio deveria ser apreendido tanto por quem fabrica a obra, quanto pelo profissional requerido somente para dar instruções e criar padrões para o fabricante. ${ }^{466}$ Nota-

\footnotetext{
461 SEMPER, Wissenschaft, Industrie und Kunst, op.cit.

462 “...der härteste Porphyr und Granit schneidet sich wie Kreide, polirt sich wie Wachs, das Elfenbein wird weich gemacht und in Formen gedrückt”. Id.Ibid., p.9.

463 Ibidem.

464 "Wie sollen wir nun den Granit behandeln? Schwer ist es, darauf eine genügende Antwort zu geben! Das Nächste wird wohl sein, dass wir ihn nur da anwenden müssen, wo seine Dauerhaftigkeit in Anspruch genommen wird, und aus dieser letzteren Bedingung die Regeln für seine stylistische Behandlung entnehmen". Id.Ibid., p.18.

465 "...eine gleichsam natürliche logisch abgeleitete Consequenz des Rohstoffes zu sein und so zu erscheinen....". SEMPER, Der Stil, vol.I, op.cit., pp.95-6.

466 Ibidem. O mesmo princípio vale para o caso em que a máquina substituir a mão no processo de fatura do artefato. O teórico sustenta que os indivíduos deveriam dominar a matéria-prima e aprender a subordinar as máquinas aos materiais e suas propriedades naturais. Nesse sentido, observa-se que, ao contrário de seu contemporâneo John Ruskin, Semper não condena a utilização da máquina nos processos de fabricação artística. Colocando questões que no século seguinte seriam melhor desenvolvidas nos métodos de ensino da escola da Bauhaus, o teórico argumenta por um uso consciente da máquina a partir da consideração dos limites e potencialidades dos materiais e de suas características, que deveriam ser conhecidos primeiramente pela experiência manual do artífice.
} 
se que tal argumentação assume relevante justificativa ao se considerar o contexto oitocentista dos artefatos da indústria moderna, ou seja, por um lado a dissimulação de materiais e as inovações em seus tratamentos, por outro a repetição de formas do passado incorporadas em substâncias carentes de sentidos e relações simbólicas. Semper contrapõe a isto a ideia de que é pelo trabalho contínuo com o material que os tipos ornamentais foram explorados em cada cultura, ou seja, é dominando a matéria e técnica de sua época que o artífice consegue dominar a linguagem artística de seu tempo.

Além disso, sustenta o autor que, em todas as culturas antigas, quando novos materiais - muitas vezes mais duráveis - foram utilizados em substituição aos antigos, os motivos antigos foram reinterpretados em novos tipos, adaptados às circunstâncias do novo material, e, nestes novos tipos, sempre sobrevivem traços formais da técnica antiga, traços que, como esclarece Mallgrave, atuam "aludindo simbolicamente aos materiais usados no passado". ${ }^{467}$

Como os tipos originários são têxteis para o autor, Semper sempre observa uma reminiscência desta técnica nos artefatos; daí, por exemplo, os ornamentos lineares que aparecem em vasos cerâmicos, derivados originariamente da cestaria (figura 30). Para o autor, a transmissão das formas nas diferentes culturas sempre foi orientada por esse processo de mudanças de material - processo que ele denominou de Stoffwechsel,$-{ }^{468}$ e é esta transposição da matéria que orienta, ou, pode-se dizer, condiciona, a repetição e diferenciação dos ornamentos.

\footnotetext{
467"symbolically alluding as it were to the materials used in the past". MALLGRAVE, Gottfried Semper. architect of the nineteenth century, op.cit., p. 284.

468 O significado literal de Stoffwechsel é mudança de material. Conforme se pode perceber no Deutsches Wörterbuch de Jacob e Wilhem Grimm, (op.cit.), este termo era relativamente novo na região de língua alemã do século XIX, indicando "mudança das substâncias" [Wandel der Stoffe], "a partir das quais os seres orgânicos se constituem" [aus welchen organische Wesen sich aufbauen], ou seja, seria o termo "metabolismo" ou o processo metabólico" da biologia. Esta expressão só aparece nos escritos mais tardios de Semper, apesar de essa ideia já estar presente na obra Die vier Elemente. De acordo com Mallgrave (Gottfried Semper: architect of the nineteenth century, op.cit), Semper provavelmente entrou em contato com este termo e seu conceito por meio das teorias químicas e materialistas de seu colega do Politécnico de Zurique, o fisiologista Jakob Moleschott. No verbete Stoffwechsel do Deutsches Wörterbuch de Jacob e Wilhem Grimm (op.cit.), aparece a definição deste termo conforme a cunhou Moleschott em sua obra Der Kreislauf des Lebens ( $1^{a}$ ed. 1852): "pois como o comércio da alma é a circulação, por isto é o eterno circular da substância a alma do mundo", tradução nossa do original "denn wie der Handel die Seele ist des Verkehrs, so ist das ewige Kreisen des Stoffes die Seele der Welt". Mallgrave (Ibid., p.285) vê esta apropriação do termo na teoria de Semper como uma tentativa de se alinhavar com o que ele via como "as forças progressivas da comunidade científica" [the progressive forces of the scientific community] e ao mesmo tempo "contestando a crença principal (materialista) das recentes teorias alemãs na arte" [countering the main thrust of recent German theories in arf].
} 


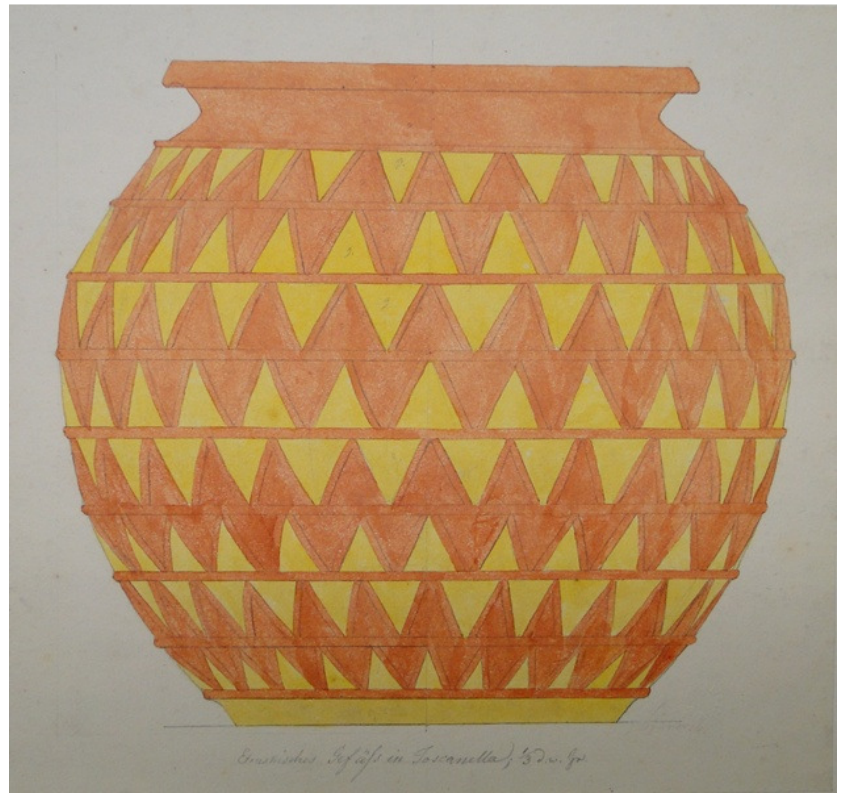

Figura 30 - Vaso etrusco da Toscana, cujo ziguezague indica uma reminiscência têxtil. Desenho de Semper. Fonte: arquivo da ETH de Zurique.

Um caso emblemático para Semper é o dos relevos assírios, cujos remanescentes o estudioso pode conhecer em visitas que realizou ao Museu do Louvre e pelo contato com as publicações que surgiram das expedições do francês Paul Emile Botta (1802-1870), e do inglês, Austen Henry Layard (18171894). ${ }^{469}$ Segundo o teórico hamburguês, tipos ornamentais dos tapetes assírios - famosos na sua época pelas esplêndidas cores e pela destreza na representação de figuras fantásticas, como animais místicos, leões, dragões, entre outros - sobreviveram nos revestimentos em pedra coloridos das salas dos palácios deste povo (figuras 31 e 32). Estes revestimentos decorativos reproduziam os tapetes antigos, como se fossem "tapetes em pedra" (figuras 33 e 34), para imortalizar os atos solenes que representavam.

469 Até meados do século XIX, era muito escasso o conhecimento dos europeus sobre a Assíria, tanto sua história quanto sua localização. Em grande medida, o que se sabia era decorrente das descrições de autores clássicos, como Heródoto, e algumas referências contidas na Bíblia, como no Gênesis e no Livro de Jonas. Foi após as expedições de um francês, Paul Emile Botta (1802-1870), e de um inglês, Austen Henry Layard (1817-1894), na década de quarenta (expedições cujos espólios formaram parte das coleções do Museu do Louvre e do Museu Britânico), que esta antiga civilização pode ser mais bem conhecida pelos europeus, acarretando seus remanescentes por despertar a curiosidade e a imaginação do público europeu, haja vista, por exemplo, sua apropriação nas pinturas de Delacroix. No entanto, ainda nesta época havia confusões quanto ao que realmente constituía o império assírio. Botta, por exemplo, publicou o resultado de suas escavações realizadas na localidade de Khorsabad em uma obra com o título Monument de Ninive (1849-1850) por acreditar ter sido ali a cidade de Nínive, mencionada na Bíblia. Também Layard publicou, por exemplo, Nineveh and ist remains (2 v.,1848-1849), obra que descreve seu trabalho de escavação na área de Nimrud. Já Semper, por vezes, ao se referir à Assíria, queria dizer o próprio império Assírio (1350612 a.C.) e também o posterior império Neo-babilônico (612-539 a.C.). 


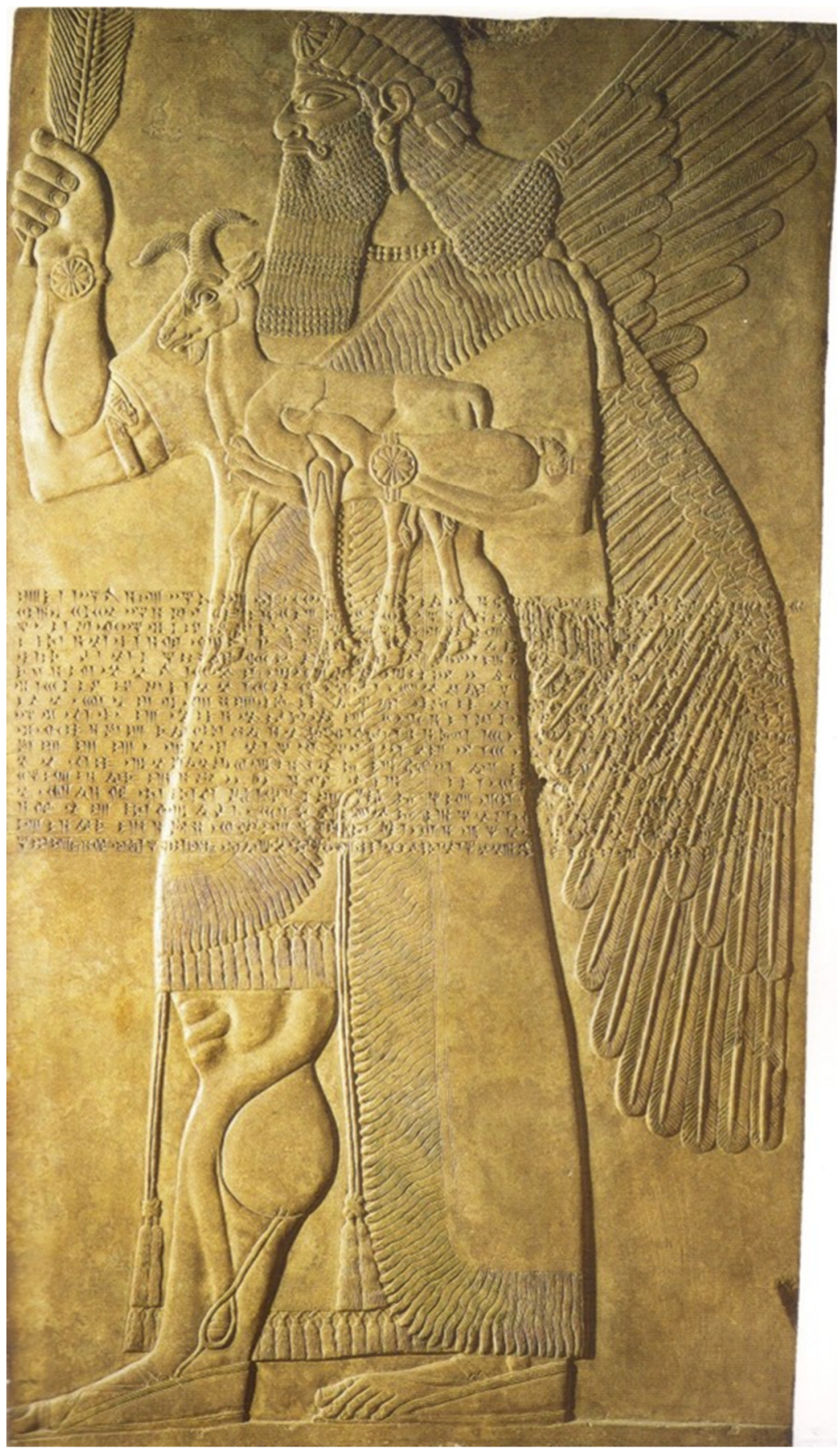

Figura 31 - Representação de um "espírito protetor" assírio. Relevo de palácio em Nimrud, cerca de 875-860 a.C. Fonte: CURTIS, J.E., READE, J.E., Art and Empire, 1995. 


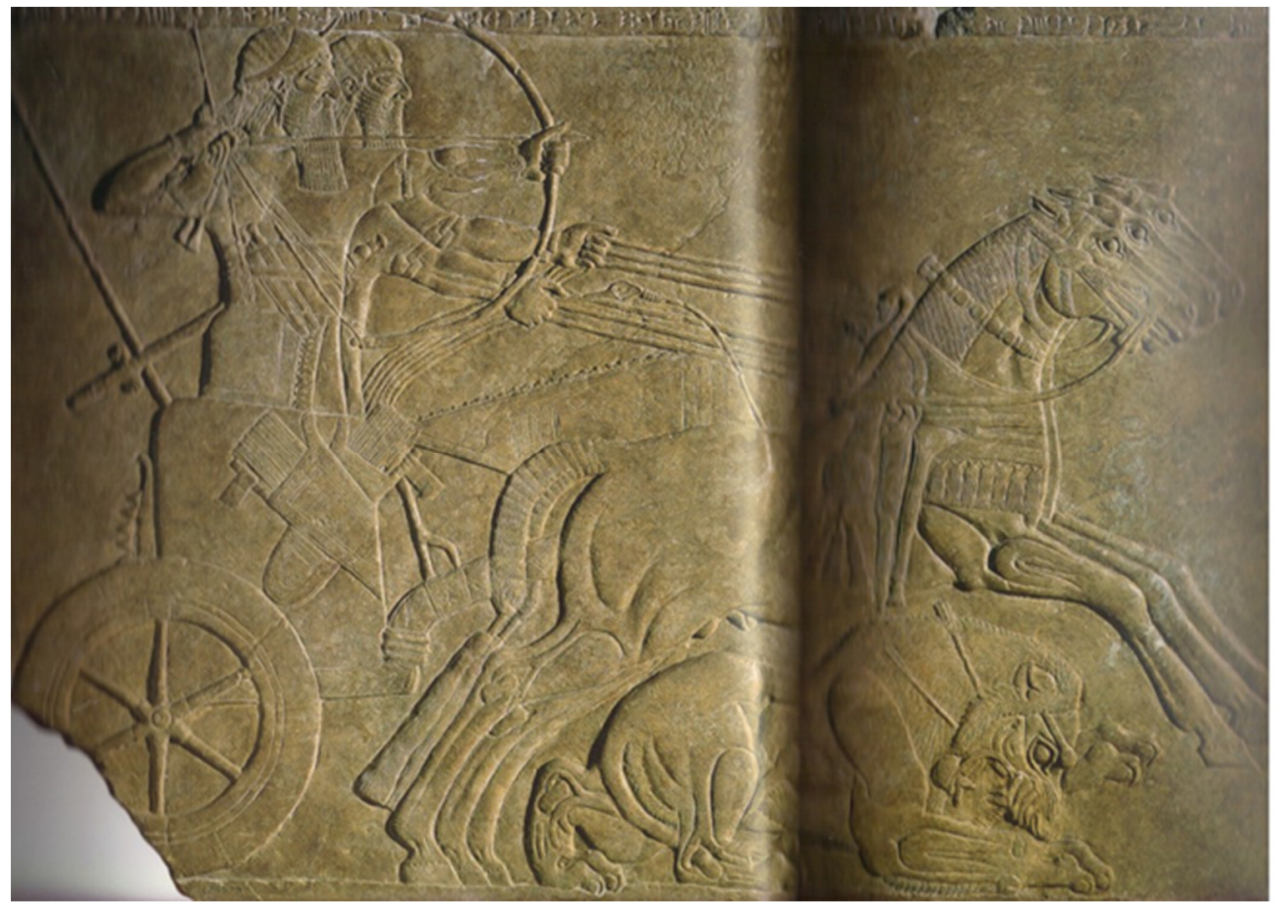

Figura 32 - Representação assíria de uma caça ao leão real, representante das forças selvagens da natureza, que deveriam ser controladas pelo rei, representado pela figura à frente (provavelmente Ashurnasirpal). Relevo (incompleto), de um palácio em Nimrud, cerca de 875-860 a.C. Fonte: CURTIS, J.E., READE, J.E., Art and Empire, 1995.

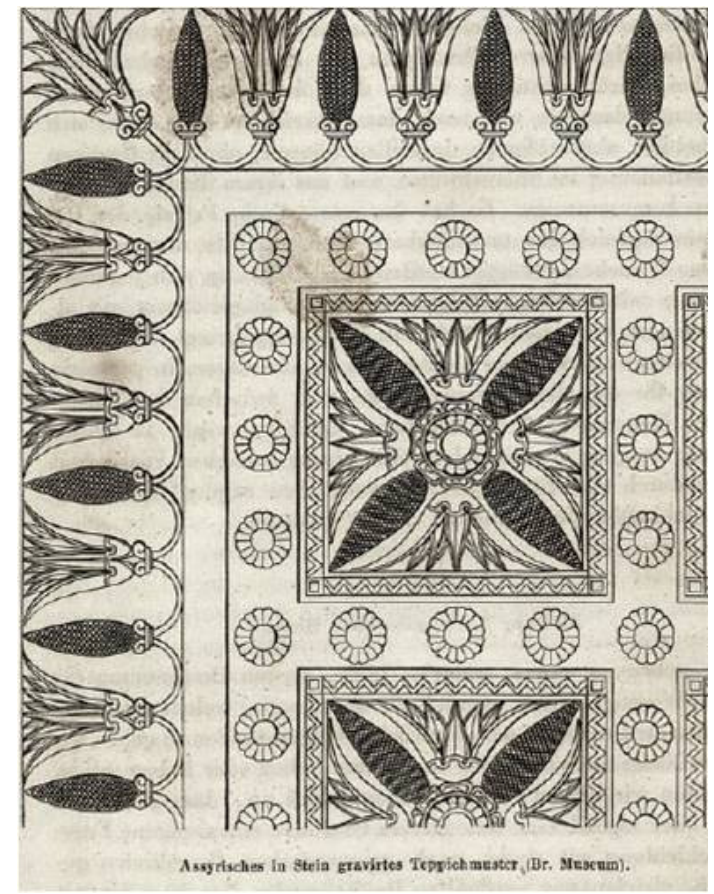

Figura 33 - Padrão de tapete assírio gravado em pedra. Desenho de Semper feito a partir do acervo do Museu Britânico. Fonte: SEMPER, Der Stil, vol.I,1860.

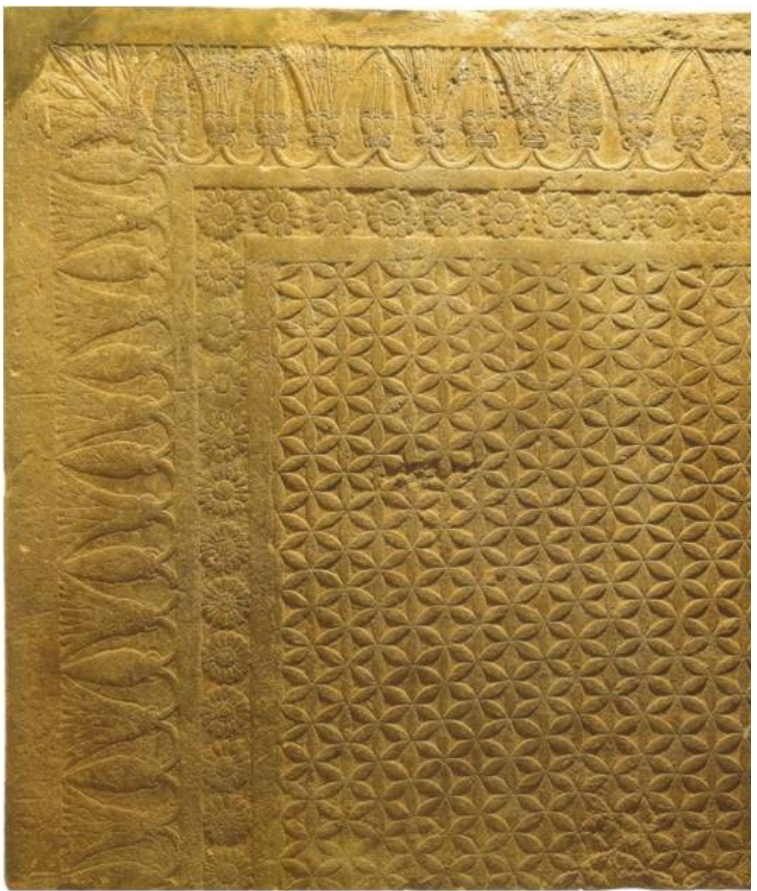

Figura 34 - Exemplo de "tapete de pedra" assírio, parte de uma das soleiras da sala do trono de Ashurbanipal em Nínive. Fonte: CURTIS, J.E., READE, J.E., Art and Empire, 1995. 
que atestava para Semper esta passagem do têxtil para a escultura pintada ou relevo pintado nos assírios, era não só a representação linear em perfil, que era muitas vezes destacada com contornos fortes - próprios ao bordado, segundo o autor -, mas principalmente a recorrência, nos relevos, de motivos ornamentais que são típicos da tapeçaria, como borlas, ${ }^{470}$ cadilhos $^{471} \mathrm{e}$ bainhas (figuras 35 e 36 ). 472
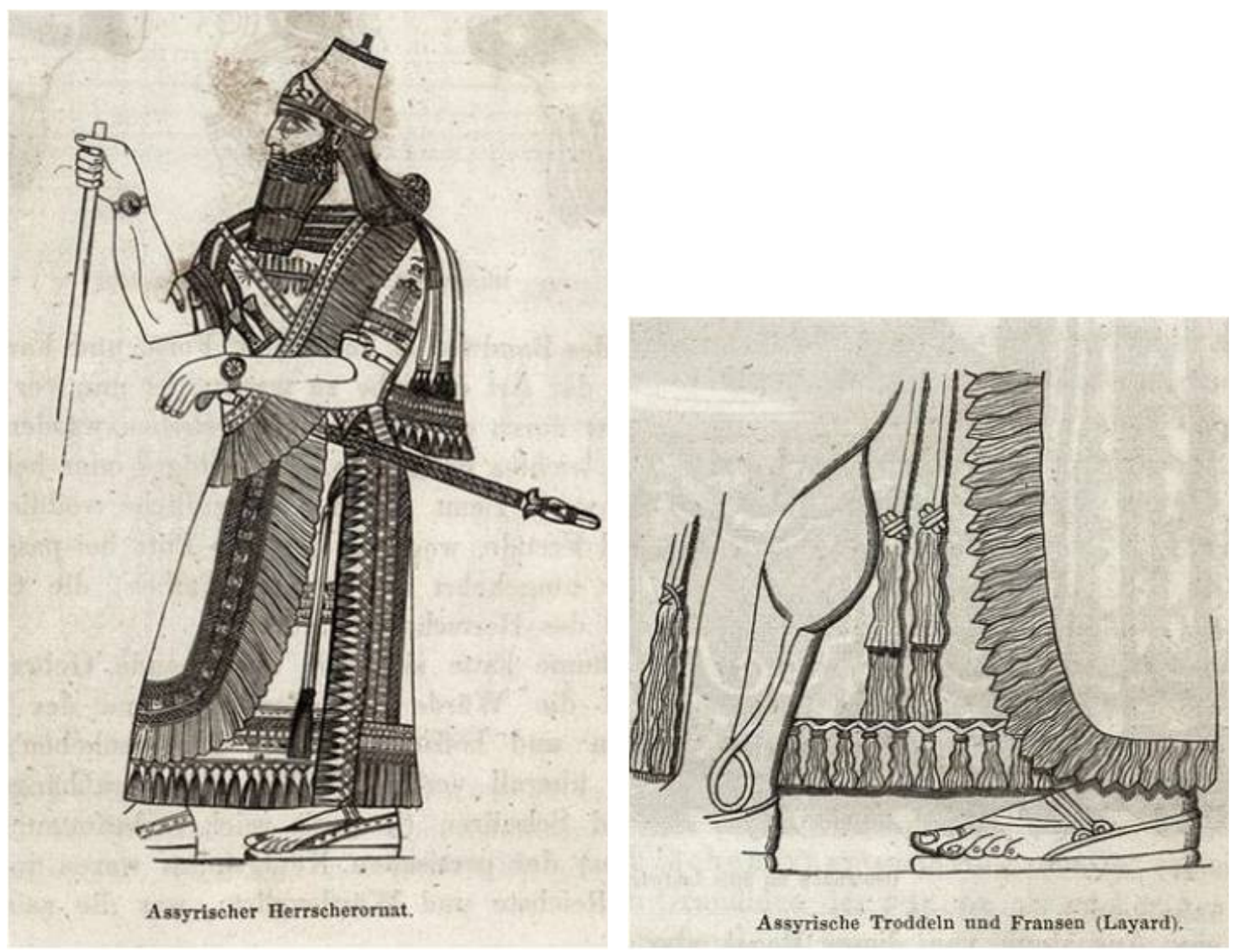

Figuras 35 e 36 - Hábito do soberano assírio, com borlas e cadilhos. Desenhos de Semper a partir da obra de Layard. Fonte: SEMPER, Der Stil, vol.I, 1860.

Entre o discurso de Semper sobre o Ornato e o de Vitrúvio revelam-se afinidades, pode-se dizer. Para ambos, os Ornamentos de modo algum são elementos arbitrários, pois representam, pode-se dizer, a memória de um

\footnotetext{
470 Obra de passamanaria, formada por um suporte do qual pendem vários fios.

471 Fios de tecido soltos, sem trama, formando uma franja.

472 Segundo Semper, "'As figuras assírias] mostram músculos duramente expressos, como com contornos rodeados de fios, a predominância de acessórios ornamentais e vestimentas bordadas, assim como muitas outras concepções primitivas e desajeitadas da origem da arte a partir dos têxteis e de exageros infantis, mas não de uma maneira morta...". Tradução nossa de "Dort zeugen [assyrischen Gestalten] hartausgedrücktes Muskelwerk, wie mit Zwirnfäden umzogene Kontouren, Vorherrschen des ornamentalen Beiwerkes und der gestickten Gewänder sowie manches andere von dem technischen Ursprunge der Kunst aus der Textrin, von primitive unbeholfener Auffassung und von kindlicher Uebertreibung, aber nicht von todter Manier,...". SEMPER, Der Stil, vol..I, op.cit., p.359.
} 
material e um ofício anteriores; no entanto, eles diferem quanto à ordem e à lógica dessa memória. Se para Vitrúvio os elementos ornamentais do entablamento dos templos clássicos como tríglifos, métopas, dentículos e mútulos desenvolveram-se da transformação de uma construção em madeira para uma em pedra e remetem a este costume, para Semper, o que Vitrúvio descreve por triglífos, por exemplo, e que ficou estabelecido pela Tradição Clássica como representando as tábuas que fazem o acabamento da vista em topo da estrutura transversal de sustentação do telhado nos templos dóricos, originalmente não tinha nenhuma relação com construção em madeira, pelo contrário, foi provavelmente derivado do têxtil, pois é como se fosse uma bainha indicando resquícios do zigue-zague da costura e inclusive é um motivo recorrente em pisos de mosaico (figura 37). ${ }^{473}$

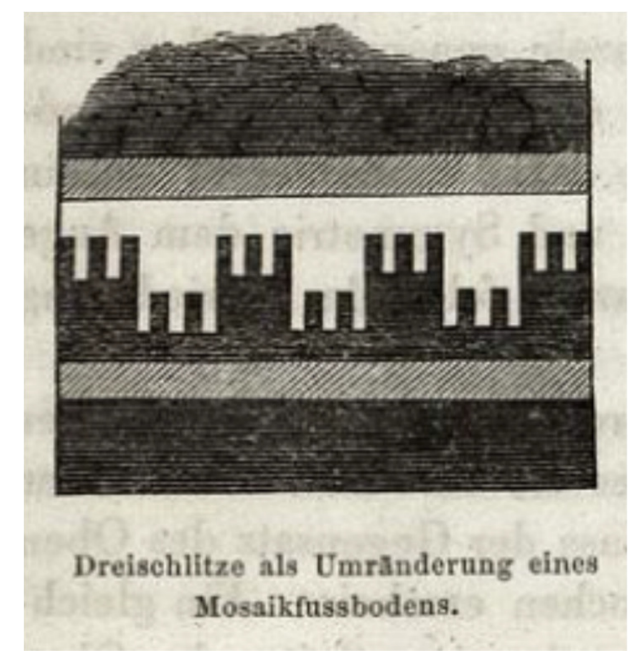

Figura 37 - Tríglifos como borda de um piso de mosaico, desenho de Semper. Fonte: SEMPER, Der Stil, vol.I, 1860.

Por outro lado, a argumentação de Semper acerca dos Ornamentos aproxima-se também daquilo que sustentaram alguns teóricos rigoristas no século XVIII, como Carlo Lodoli, por exemplo, na medida em que este, criticando a tradição vitruviana da crença na mudança da madeira para a pedra, defendia, em contrapartida, a observância estrita das necessidades do material em termos de maleabilidade, resistência, textura, entre outras. Em Semper, na mudança de material, por mais que os ornamentos evidenciem reminiscências da técnica

${ }^{473}$ SEMPER, Der Stil, vol. I, op.cit. 
antiga, sua aparência é condicionada pelo novo material. Trata-se, pode-se dizer, de uma ética na fabricação, de adequação dos meios aos fins, que faz frente completamente à certa prática consuetudinária defendida por Vitrúvio.

Outra afinidade do Ornato semperiano com o de Vitrúvio, e também com o exposto por Alberti, está na importância do Ornamento em conferir um aspecto agradável ao olhar. Isso porque, na compreensão de Semper, ele serve tanto para esconder as imperfeições e falhas ocasionadas pela transposição de material, quanto para realçar as formas bem resolvidas. ${ }^{474}$ Somado a isso, ele age também de modo a dissimular justamente o aspecto de matéria inerte e todos os limites a ela associados, como peso e resistência. Se o adorno corporal dissimula a realidade ordinária do homem, seu estado de natureza, elevando qualquer um à condição de pessoa, o Ornamento usado na obra de Arquitetura, sua decoração de um modo geral, mascara o aspecto construtivo, e, com isto, possibilita a transmissão de sentidos ao espectador, de ideias ou assuntos, e deste modo, eleva a construção ao status de monumento. ${ }^{475}$ Semper qualifica estes propósitos do Ornato como a tarefa de "fazer da necessidade uma virtude". 476 Trata-se aqui, de um artifício necessário, ou - para usar uma expressão que é título de uma obra de Joseph Rykwert - da "necessidade do artifício". ${ }^{477}$

Um exemplo fornecido pelo autor é o caso dos chalés Suíços em que as rachaduras que eventualmente surgem nas vigas em madeira devido às tensões resultantes das cargas são em muitas localidades trabalhadas com ornamentos lineares entalhados ao longo de seu comprimento, em direção ao centro, de modo que "as rachaduras que seguem a mesma direção desaparecem entre as incisões horizontais onduladas". 478 Outro caso mencionado ocorre em paredes decorativas de ladrilho ou pedra incrustada, nas quais a própria decoração, incrementada pelo colorido, atenua ou mascara as linhas das juntas e com elas

\footnotetext{
474 Semper sustenta que ele serve para "corrigir certa indeterminação ou também certos limites transgredidos da pura forma...". Tradução de "...um gewisse Unbestimmtheiten oder auch gewisse überschrittene Grenzen der reinen Form zu corrigieren...". SEMPER, Der Stil, v.II., op.cit., p.85

475 Nota-se aqui que, ao defender, a dissimulação dos aspectos ligados à materialidade da Arquitetura na aparência da obra, o teórico, de certo modo, alinha seu pensamento ao dos filósofos idealistas que viam nas características materiais uma limitação da Arquitetura como arte.

476 “... aus der Noth eine Tugend zu machen”. SEMPER, Der Stil, v.I, op.cit., p.79.

477 RYKWERT, The necessity of artifice, op.cit..

478"So verschwinden die Risse, der gleichen Richtung folgend, zwischen den horizontal gewellten einschnitten". SEMPER, Der Stil, vol. II, op.cit., p.258.
} 
a materialidade construtiva, deste modo, evidenciando somente os elementos representados (figura 38).

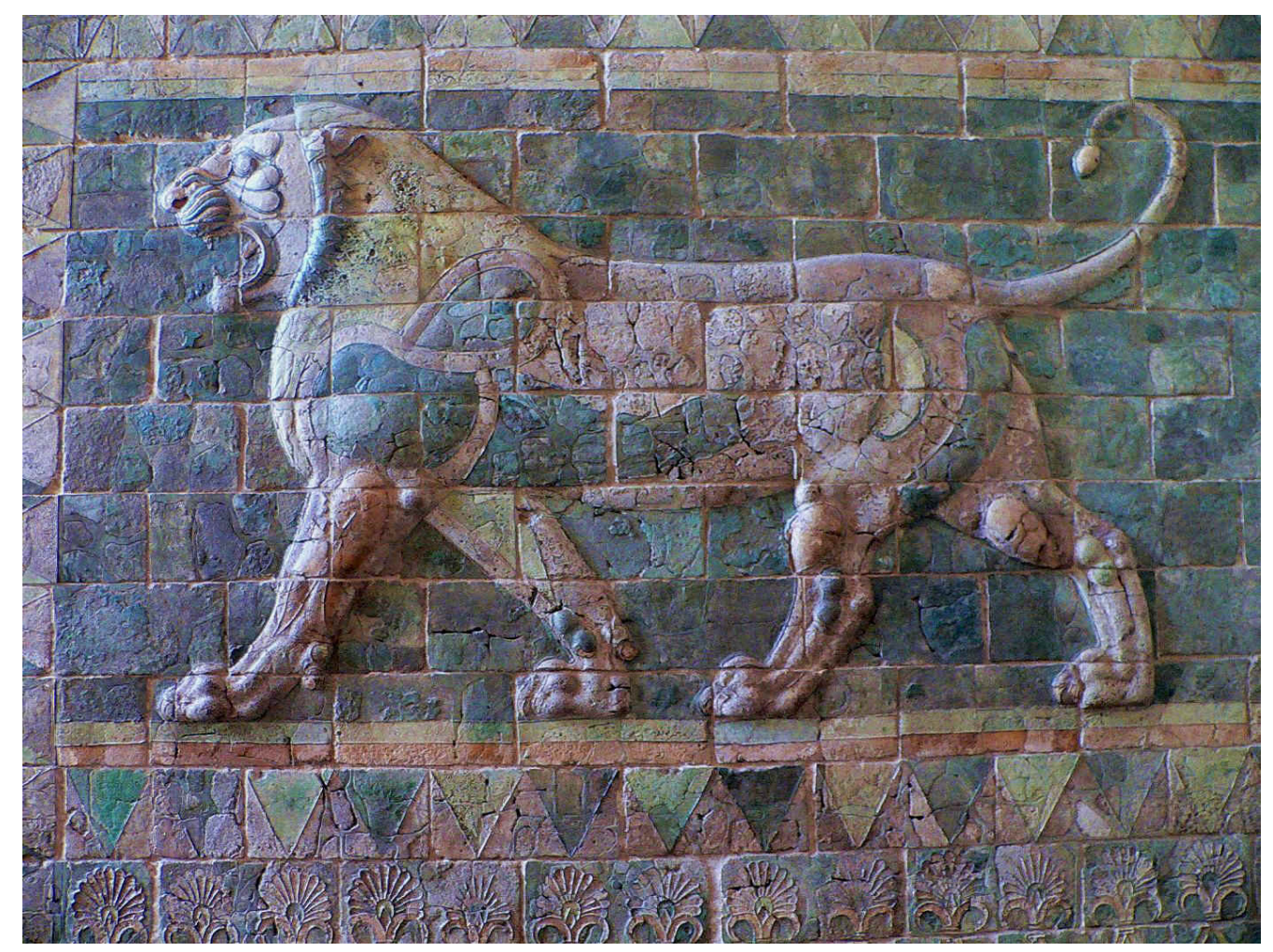

Figura 38 - Representação de leão em ladrilhos coloridos, palácio de Susa, antigo império persa. Fonte: historyofpaintings.com

Um importante exemplo do Der Stil em que Semper discorre sobre o Estilo de uma obra analisando-o conjuntamente às transformações estilísticas do Ornamento é o da sítula egípcia (figura 39). Trata-de de um recipiente cerâmico, em formato semelhante a uma gota e com uma alça superior, usado para recolher água do Nilo. Semper argumenta que seu formato e sua composição são adequados ao propósito de recolher água e estão em conformidade às condições em que esta atividade era desenvolvida nesta civilização. Isto porque no Egito a água era recolhida do rio, não brotava de rochas, por isto seu formato em gota com uma alça superior. A alça também era adequada para o modo como o recipiente era carregado, em uma grande vara com uma sítula em cada ponta e sendo sustentada por dois carregadores.

Somado a isso, o autor procura demonstrar como alguns ornamentos do modelo de sítula que ele analisa evidenciam a transposição de material que o artefato sofreu nesta cultura. Originalmente um tubo de couro amarrado na boca, 
as faixas de hieróglifos que partem do aro superior indicam, na interpretação de Semper, as antigas dobras do couro, bem como os ornamentos vegetais na parte debaixo apontam para possíveis marcas no antigo material em virtude do desgaste devido ao peso da água, além de dissimularem quaisquer imperfeições na cerâmica. Por fim, a análise conclusiva de Semper é que o formato geral da situla egípcia - o qual é reforçado pelos ornamentos - expressa a força da gravidade, remete a um aspecto de peso e - associado a ele - de dominação que Semper observa também na arquitetura egípcia, aspecto que corresponde a uma característica da civilização egípcia de um modo geral, como se mostrará a seguir.

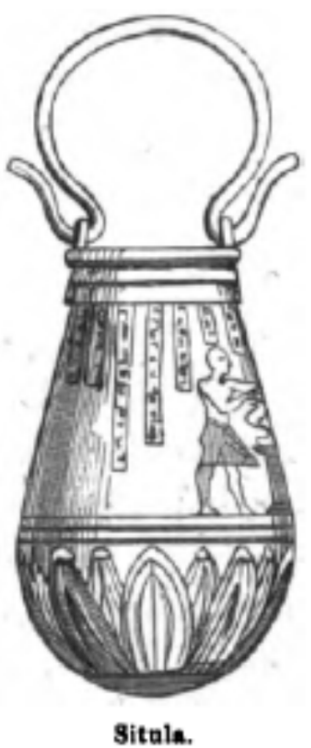

Figura 39 - Sítula egípcia, desenho de Semper. Fonte: SEMPER, Der Stil, vol.I, 1860. 


\section{O ORNAMENTO COMO ORDEM}

Gottfried Semper tem a opinião de que "a confusa mistura de formas"479 dos artefatos contemporâneos é devida, em grande medida, a uma falta de consciência da seriedade do propósito, daquilo que é adequado e apropriado em termos da forma e dos Ornamentos que a decoram. ${ }^{480}$ No caso da Arquitetura, o risco de se ter uma confusão é maior, uma vez que, para o autor, esta arte caracteriza-se justamente pela junção de partes separadas, pelo "modelar e cortar materiais naturais e sem forma [transformando-os] em formas regulares" ${ }^{481}$ as quais necessitam de princípios ordenadores.

Em um contexto em que as relações lógicas entre as partes da Arquitetura, anteriormente fundamentadas no sistema de ordens clássico, não possui mais a autoridade de antes, Semper, com sua teorização sobre o Ornamento, procura refundar estas relações, restabelecer, por exemplo, a unidade e o sentido de adequação entre as partes estruturais e decorativas da edificação. Trata-se de restabelecer uma ordem, a qual, para Semper, evidenciou-se de modo exemplar só na Arquitetura grega. Isso porque, para o autor, esta Arquitetura

teve suas ressureições e não morrerá em seus princípios pelo fato de que são fundamentados na natureza, porque eles são de verdade geral e absoluta, e falam a nós em uma linguagem a qual é compreensível por si mesma em qualquer época e em qualquer lugar, aquela da própria natureza. ${ }^{482}$

Só os gregos souberam expressar mais claramente em suas arquiteturas a legalidade da natureza, só eles intuíram e seguiram mais fielmente as leis do universo em seus artefatos, algo que seria demonstrável pelo sentido que a

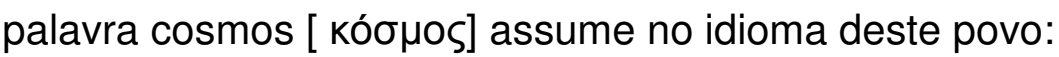

o rico e preciso idioma dos helenos tem a mesma palavra para a designação da decoração com a qual nós adornamos a nós

\footnotetext{
479 Idem nota 20.

480 SEMPER, Wissenschaft, Industrie und Kunst, op.cit.

481 "O primeiro passo em direção à Arquitetura como uma arte verdadeira seria modelar e cortar materiais naturais e sem forma [transformando-os] em formas regulares..." Tradução de "The first step towards architecture as a real art would appear to be the modelling and cutting [of] natural and formless materials into regular forms...". SEMPER, On architectural symbols, op.cit., p.62.

482"... had its ressurections and will never die in its principles for the reason because they are based upon nature, because they are of general absolute truth, and speak to us in a language which is comprehensible by itself in every age and at every place, that of nature alone". Id.Ibid., p.62.
} 
mesmos e aos objetos de nosso apreço e a mais elevada legalidade da natureza e ordem do universo [...]. Para o heleno, o adorno era, em sua legalidade cósmica, o reflexo da ordem geral do universo como ela se nos apresenta concretamente aos sentidos no universo fenomenal... ${ }^{483}$

Semper crê que o modo como os gregos ornamentavam era um exemplo a ser seguido na contemporaneidade, não copiado, mas emulado. Cada cultura deveria elaborar seus tipos ornamentais tendo em vista a linguagem universal da natureza, a qual se apresenta de modo incontestável nas arquiteturas dos helenos. Só os princípios manifestos ali são adequados para a lógica de mercado mundial que se evidenciava em meados do século e que teve seu mais vívido exemplo na exposição industrial londrina de 1851.484

Nessa nova ordem capitalista que se impunha - resultado de um processo que parecia inexorável aos olhos do teórico $0^{485}$ - os artefatos, para servir a esse mercado mundial, deveriam ter suas peculiaridades atenuadas, sobretudo as de conteúdo religioso - que são próprias a cada cultura em particular -, e ter seu propósito ressaltado. Pois este sim é universal, o mesmo em todos os tempos e lugares, e destacá-lo permite que a obra seja compreensível por qualquer um. ${ }^{486}$

O papel ordenador do Ornamento é justamente este, acredita Semper, o de corresponder ao propósito particular de cada artefato e evidenciar tanto este quanto sua forma. ${ }^{487}$ Por um lado, isto implica em atender a uma conveniência na escolha das decorações, ou seja, dos assuntos a que elas se referem - algo que remete ao postulado do decoro clássico -, como os gregos fizeram com seus artefatos cerâmicos, por exemplo, ao explorar "a referência de cenas báquicas, [assim como] da gavinha de vinha, da folha de hera, das cabeças de pantera,

\footnotetext{
483 "die reiche und präcise Sprache der Hellenen hat dasselbe Wort zur Bezeichnung des Zierrathes, womit wir uns und die Gegenstände unserer Neigung schmücken, und der höchsten Naturgesetzlichkeit und Weltordnung.[...] Dem Hellenen war der Schmuck in seiner kosmischen Gesetzlichkeit der Reflex der allgemeinen Weltordnung, wie sie uns in der Erscheinungswelt den Sinnen fasslich entgegentritt...". SEMPER, Über die formelle Gesetzmässigkeit des Schmuckes..., op.cit., p.101.

${ }^{484} \mathrm{Em}$ Wissenschaft, Industrie und Kunst (op.cit., p.3), Semper caracteriza a exposição de 1851 como um "mercado mundial" [Weltmarket] que deixou estímulos marcantes em muitos que a experienciaram e cujas consequências de longo alcance eram impossíveis de serem medidas.

$485 \mathrm{O}$ autor observa que, na exposição, em muitas das principais potências, "tudo é calculado e feito sob medida para o mercado". Tradução de "Alles ist auf den Markt berechnet und zugeschnitten". Ibidem, p.24. ${ }^{486}$ Os efeitos dessa lógica do mercado já estavam em rápido andamento nas condições de construção de casas nos Estados Unidos. Conforme o estudioso (Ibidem), as habitações desta nação, suas partes, componentes construtivos, mobiliário e elementos decorativos não eram desenhados para terem uma destinação particular, antes eram feitos para servirem e se adaptarem a qualquer lugar.

487"Além das condições mais gerais do Estilo, o Ornamento deve ainda, em segundo lugar, corresponder pormenorizadamente ao propósito particular e à forma de todo recipiente". Tradução de "Ausser den allgemeineren Bedingungen des Stils muss das Ornament noch zweitens der besonderen Bestimmung und Form jedes Gefässes im Einzelnen entsprechen". SEMPER, Der Stil, vol.II, op.cit., p.86.
} 
das máscaras para recipientes de beber e misturar, ou das cenas de jogos competitivos e da folha de oliva para ânforas panatenaicas e semelhantes". ${ }^{488}$ Por outro, isto se refere também à "relação puramente formal, do meio decorativo aplicado, qualquer que seja ele, com o recipiente". ${ }^{489}$ Isto quer dizer que, como o Ornato não é um meio autônomo, ou seja, necessita de um suporte, com o qual se relaciona, e só tem seu sentido completado quando utilizado neste suporte seja ele o corpo humano, um objeto ou uma edificação - seu propósito mais geral é organizar a sintaxe formal deste suporte, ou melhor, da obra como um todo.

Tendo como referência a arquitetura dos templos gregos, que nos escritos de Semper é na maioria das vezes investigada em diálogo com a dos egípcios e assírios, Semper procura evidenciar quais são os locais apropriados ao Ornato na obra arquitetônica. Trata-se de estabelecer uma ordem visual, na qual estão ao mesmo tempo implicados e intrinsecamente relacionados atributos de beleza, estruturais e utilitários da edificação. O escopo do presente capítulo é demonstrar, mediante a análise do discurso de Semper sobre a ornamentação de gregos, egípcios e assírios, esse papel ordenador atribuído aos "investimentos simbólicos da estrutura nua, com a ajuda dos quais nós damos um significado mais elevado, expressão artística e beleza" à Arquitetura. ${ }^{490}$

\subsection{A união do princípio decorativo ao princípio estrutural}

Uma das principais referências e interlocuções de Semper na elaboração de uma teorização do Ornamento foram os estudos do arqueólogo de língua alemã Karl Bötticher (1806-1889). A partir da década de 1840, Bötticher obteve reconhecimento no meio erudito por suas investigações sobre a arquitetura

\footnotetext{
488 O trecho completo é "[isto se refere não só aos assuntos das representações, que se utiliza para propósitos decorativos, e sua escolha correspondente, como por exemplo] a referência de cenas báquicas, da gavinha de vinha, da folha de hera, das cabeças de pantera, das máscaras para recipientes de beber e misturar, ou das cenas de jogos competitivos e da folha de oliva para ânforas panatenaicas e semelhantes...". Tradução de "[Diess betrifft nicht sowohl das Gegenständliche der Darstellungen, die man zu dekorativen Zwecken benützt, und deren passende Wahl, wie z.B.] der Bezug bakchischer Scenen, der Weinranke, des Epheublattes, der Pantherköpfe, der Masken, zu Trink- und Mischgefässen, oder der Kampfspielscenen und des Oelblattes zu panathenäischen Amphoren und dergl. andere..." Id.Ibid., p.86-7, colchetes nossos.

489 "...das rein formale Verhalten der angewandten dekorativen Mittel, welcher Art sie sein mögen, zu dem Gefässe". Id.lbid., p.87.

490"... symbolical investments of the bare structure, with the aid of which we give higher significance, artistical expression and beauty to the last'. SEMPER, On architectural symbols, op.cit., p.61.
} 
grega, publicadas na obra Die Tektonik der Hellenen (1844-1852). ${ }^{491}$ Como o título sugere, Bötticher segue a definição de Tectônica de Müller 492 e seu enfoque direciona-se à arquitetura do templo dórico grego em pedra, que ele vê como a expressão tectônica mais perfeita, criação espontânea e autóctone da tribo dórica. ${ }^{493}$ Para o autor, trata-se de um ideal, que não necessariamente deve ser copiado - seu estudo pretende "trazer a essência da Tectônica helênica em teoria, em ponto de vista" ${ }^{494}$ _, mas sim ter seus princípios tomados como referência para a Arquitetura de sua época, ${ }^{495}$ a qual encontrava-se desunificada em virtude da difusão dos revivalismos na primeira metade do século. ${ }^{496}$

Bötticher compreende a Arquitetura como composta por duas partes, a parte construtiva, denominada Kernform, e a parte decorativa e embelezadora, a Kunstform. ${ }^{497}$ A parte decorativa de modo algum deveria ser tomada como algo supérfluo, pelo contrário, a ornamentação assume em sua obra uma importância fundamental; consoante explica Frank-Lothar Kroll, para Bötticher,

uma construção sem 'formas decorativas' seria não mais que um amontoado de pedras mortas, uma ossatura sem a menor importância artística e profundamente não estética. Falta o adorno, então também arte e beleza estão incompletas. ${ }^{498}$

\footnotetext{
491 BÖTTICHER, Karl. Die Tektonik der Hellenen. Potsdam: Verlag von Ferdinand Riegel, 1852. O primeiro volume foi publicado em 1843, o livro 4 do segundo volume em 1849, os livros 2 e 3 do segundo volume em 1851 e a edição completa em dois volumes surgiu no ano de 1852.

492 Bötticher inclusive dedica Die Tektonik der Hellenen a Müller, além de Karl Friedrich Schinkel (1781 1841), duas das principais referências de seus estudos. Sua definição do termo é a seguinte: "sob Tectônica compreendemos em sentido estrito: a atividade formativa de edificações e equipamentos, na medida em que a mesma consiga sustentar eticamente sua tarefa resultante da necessidade da vida espiritual ou física, e então não somente corresponder às meras necessidades através de uma conformação corpórea necessária materialmente, mas sim poder elevar esta última também à forma artística". Tradução de "Unter Tektonik begreifen wir im engeren Sinne: die bauliche und Geräthebildende Werkthätigkeit, sobald dieselbe ihre aus Bedürfnissen des geistigen oder physichen Lebens hervorgegangenen Aufgaben ethisch zu durchbringen vermag, und sonach nicht allein dem bloßen Bedürfnisse durch eine materiell nothwendige Körperbildung zu entsprechen, sondern die Letztere auch noch zur Kunstform zu erheben vermag". BÖTTICHER, Die Tektonik..., v.l, op.cit., p.3.

${ }^{493}$ Id. Ibid.

494 “...das Wesen der hellenischen Tektonik zur Theorie, zur Anschauung zu bringen...”. Id.Ibid., p.IX.

495 Sobre as investigações de Bötticher acerca do Estilo, conferir HAVTTUM, Mari. Crisis and correspondence: style in the nineteenth century. Architectural Histories, n.I, vol. I, pp.1-8, 2013.

496 SCHWARZER, Mitchell. Ontology and representation in Karl Bötticher's theory of tectonics. In: Journal of the Society of Architectural Historians, Vol. 52, No. 3, Set., 1993, pp. 267-280.

497 As traduções literais destes dois termos seriam respectivamente, forma núcleo ou forma essência e forma de arte ou forma artística. Optou-se aqui por manter os vocábulos na língua original, conforme criados pelo autor. Em edição posterior de Die Tektonik, o autor usa ao invés de Kernform a palavra Werkform. A tradução de Werk é obra, trabalho, tarefa.

498 'Ein Bau ohne 'Zierformen' wäre nicht viel mehr als ein Haufen toter Steine, ein Gerippe ohne den geringsten künstlerischen Wert und zutiefst unästhetisch. Felht der Schmuck, so sind auch Kunst und Schönheit unvollständig". LOTHAR-KROLL, Das Ornament in der Kunsttheorie des 19.Jahrhunderts, op.cit., p.22-3, aspas do autor.
} 
Mas também a parte mecânica é um item fundamental, que não pode ser negada, pois para Bötticher ela constitui a essência da Arquitetura e é o que a particulariza. Na relação entre estrutura e decoração, ${ }^{499}$ a Kunstform, longe de ser explorada arbitrariamente, deveria como que "surgir" da Kernform e decorála, algo que historicamente só foi alcançado com perfeição pelos gregos. ${ }^{500}$

Semper entrou em contato com os escritos do colega durante os anos de exílio em Londres, momento a partir do qual, consoante coloca Herrmann, ele se apropriou de parte das ideias do autor de Die Tektonik, muitas vezes utilizando-as sem a devida referência. ${ }^{501}$ Mas, diferentemente de Bötticher, que em sua obra tem como foco os gregos, no Der Stil Semper se dispõe a investigar a relação entre a Kernform e a Kunstform em alguns dos principais povos da Antiguidade. Os monumentos, principalmente de egípcios, assírios e gregos, são estudados tendo em vista a conexão da estrutura com aquilo que Semper compreendia ser o elemento que caracteriza a Arquitetura em todos os tempos e o que distingue os diferentes Estilos, ou seja, o revestimento decorativo.

Consoante o autor do Der Stil, enquanto nos egípcios a estrutura das massivas paredes encontra-se escondida por trás das placas decorativas, ocultando a atenção a um dos importantes aspectos da Arquitetura, a saber, a "estrita observância dos princípios estáticos e mecânicos, quer dizer, das leis as quais a própria natureza observa na criação de suas várias formas", 502 as colunas dos palácios assírios, estruturas de carpintaria revestidas por placas de metal, já mostram uma mudança em relação a isto.

Foi a introdução do metal como material de revestimento que possibilitou relevantes transformações nos utensílios e na Arquitetura assíria. Revestir núcleos de madeira com placas metálicas, segundo o autor, é uma prática originária de antigas estátuas de culto, foi utilizada no mobiliário assírio e em

\footnotetext{
499 A separação da Arquitetura em estrutura e decoração já havia sido sugerida por outros estudiosos, como Hegel, por exemplo, mas foi Bötticher quem estruturou uma teoria a partir disto. Sobre a relação de Bötticher e Hegel, conferir KROLL, Frank-Lothar. Das Ornament in der Kunsttheorie des 19. Jahrhunderts, op.cit.,pp. 19-27.

500 Apesar da evidente predileção pelo classicismo grego, Bötticher não concordava com a assunção de que o templo helênico e seus ornamentos teriam surgido de uma cabana em madeira; pelo contrário, para ele, todas as formas foram diretamente derivadas da pedra. Esta mesma racionalidade construtiva deveria guiar a arquitetura contemporânea, na medida em que o conhecimento arquitetônico deveria estar fundado na realidade dos materiais e das demandas práticas e utilitárias. Cf. SCHWARZER, Mitchell. Ontology and representation in Karl Bötticher's theory of tectonics, op.cit.

501 Conferir HERRMANN, Wolfgang. Semper and the archeologist Bötticher. In: Gottfried Semper: in search of architecture, op.cit., pp.139-152.

502 "...the strict observance of the statical and mechanical principles, that is to say to the laws which nature itself observes in the creation of its various forms". SEMPER, On architectural symbols, op.cit., p.61.
} 
seguida alcançou as construções deste povo, ou seja, trata-se de algo que foi sendo transmitido entre as gerações. ${ }^{503}$ No revestimento do mobiliário, os ornamentos resultam das dobras, curvas e rebites do metal e mostram uma maior liberdade e riqueza decorativa do que os trabalhos de móveis somente em madeira, como Semper procura demonstrar em uma comparação entre um carro de combate egípcio em madeira e um assírio revestido com metal (figuras 40 e 41):504
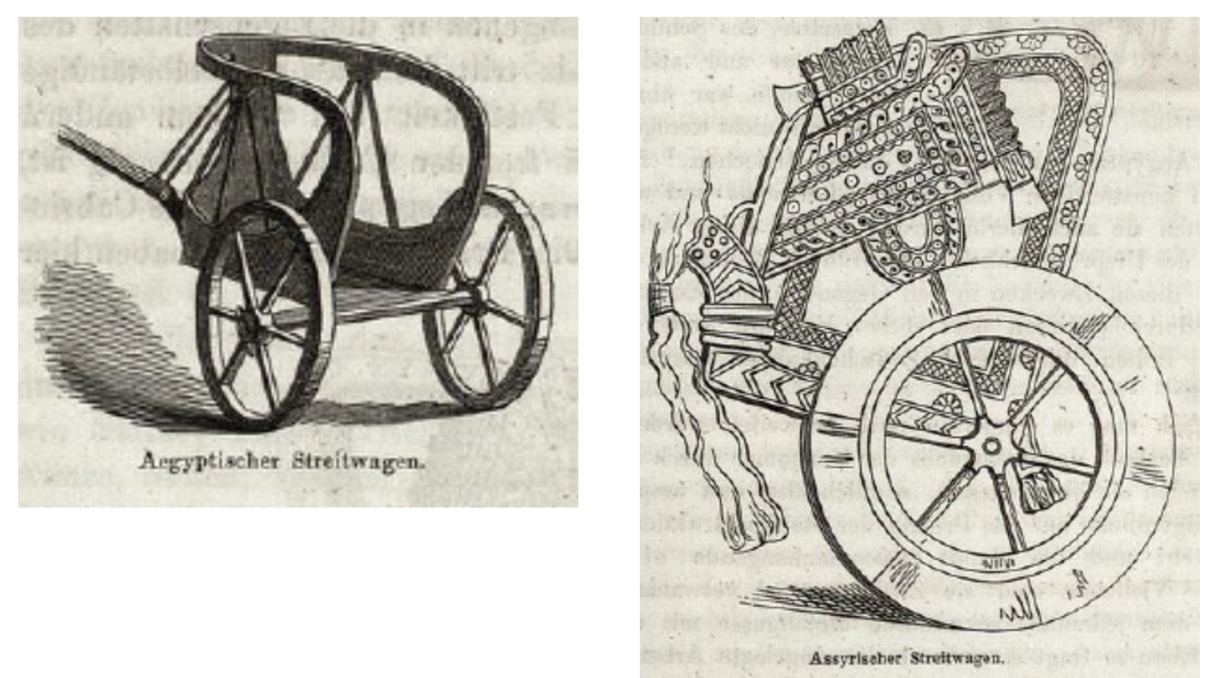

Figuras 40 e 41 - Carros de combate egípcio e assírio, desenhos de Semper. Fonte: SEMPER, Der Stil, vol.I, 1860.

O autor atesta que, com o tempo, percebeu-se que o metal também apresentava a rigidez e a estabilidade necessárias a ponto de o núcleo em madeira ser tomado como prescindível e estabelecer-se, no mobiliário e nas colunas arquitetônicas dos assírios, o "princípio da construção tubular"505 ou construção oca em metal. A partir do domínio desta técnica, estrutura e decoração estão associadas, partem de um mesmo material e de um mesmo princípio, e os ornamentos não parecem terem sido aplicados "de fora".

Com isso, Semper chega à conclusão de que, comparativamente aos egípcios, só nos assírios o princípio ornamental [Kunstschema ou ornamentale Prinzip] está associado ao princípio construtivo [Strukturschema ou konstruktive Prinzip], ou seja, ambos são os mesmos e um só e estão evidentes na aparência:

503 SEMPER, Der Stil, vol.I, op.cit.

504 Id. Ibid.

505 "Prinzip der Tubularkonstruktion". Ibidem, p.376. 
revelam-se duas antíteses: o estilo arquitetônico da Ásia ocidental (o caldeu-assírio) e o estilo arquitetônico do Egito faraônico, oposições [manifestadas] nas condições mais gerais de surgimento e crescimento dos modelos arquitetônicos de ambos países, nos aspectos das massas que eles evidenciam... $\mathrm{Na}$ arquitetura caldeu-assíria, mais tardia e já desenvolvida, o revestimento é juntamente o princípio construtivo e ornamental; a única solidez na edificação é sua crosta e procedimentos puramente técnicos que geram o Kunstschema arquitetônico e até o ornamento...O [Estilo] egípcio, pelo contrário, não quer de qualquer modo o revestimento ligado à ideia segundo a estrutura, e então esta última absorve efetivamente o revestimento; a estrutura torna-se pedra massiva, o revestimento é cinzelado a partir dela, retendo, pode-se assim dizer, sua própria essência antiestrutural...506

\section{Segundo Semper, a técnica da construção tubular}

domina completamente a totalidade dos utensílios dos assírios e aí se desenvolve no modo mais notável, por assim dizer, de dentro para fora; quer dizer, o que antes dava a sustentação da estrutura, [...] transfere suas funções para a casca envoltória e desaparece; por fim, unem-se ambos, o momento estrutural e o formal! ${ }^{507}$

Isto significa que a ornamentação deve fazer parte da estrutura, surgir "de dentro para fora", como um organismo, uma planta que se desenvolve a partir da semente. O extremo oposto ocorreria no Egito, de arquitetura inorgânica, característica que o autor procura destacar, muitas vezes forçosamente, como é o caso da coluna com capitel em forma de botão de lótus (figura 42), que segundo ele "não pode existir sem o imaginado pilar interno"508 :

como aquelas pupadas ou mumificadas colunas com capitéis de botão, também todas as paredes, segundo os mesmos princípios, são totalmente, por assim dizer, embrulhadas em tapetes; o núcleo em pedra como tal, a saber, como estrutura,

\footnotetext{
506 "Zwei Antithesen stellten sich heraus: der Baustil des westlichen Asiens (der chaldäo-assyrische) und der Baustil des pharaonischen Aegyptens, Gegensätze [...] in den allgemeinsten Entstehungs- und Wachsthumsbedingungen der architektonischen Gebilde beider Länder, [...] in den Massenerscheinungen die sie bieten...Die Bekleidung ist in der späteren schon ausgebildeten chaldäo-assyrischen Baukunst das gemeinsam konstruktive und ornamentale Prinzip; das einzig Feste am Hause ist dessen Kruste, und rein technische Proceduren, die [...] generiren das architektonische Kunstschema, und sogar das Ornament...Der Aegypter dagegen will nicht dass die Bekleidung irgend wie der ldee nach mit der Struktur zusammenhange und doch absorbirt diese faktisch die Bekleidung; die struktur wird massiv steinern, die Bekleidung wird aus ihr herausgeschnitten, hat aber ihr eigenes, man möchte sagen antistruktives Sein...". SEMPER, Der Stil, vol.I, op.cit., p.443.

507 "Diese Technik beherrscht vollständig das gesammte Geräthewesen der Assyrier, und sie entwickelt sich daran in höchst bemerkenswerther Weise, sozusagen von Innen nach Aussen, das heisst, was früher den Halt der Struktur gab [...], überträgt seine Funktionen an die umgebende Schale und verschwindet; letztere vereinigt in sich beides, das struktive und das formale Moment!" Ibidem, pp.389-390.

508 "...ohne den hinzugedachten inneren Pfeiler nicht bestehen kann..." lbidem, p.422.
} 
não chega a aparecer, também não atua diferentemente, na medida em que mantém a si mesmo ereto e permanece firme. ${ }^{509}$

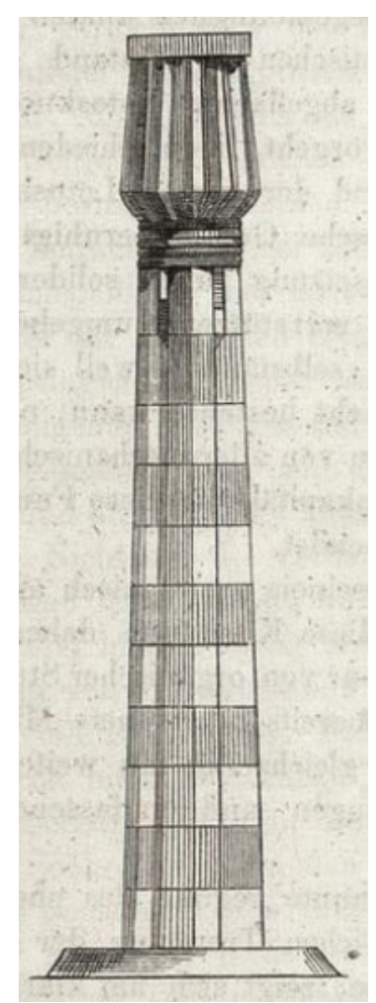

Figura 42 - Coluna egípcia com capitel de botão de lótus, desenho de Semper. Fonte: SEMPER, Der Stil, vol.I, 1860.

O processo técnico que nos assírios uniu o princípio decorativo ao estrutural, segundo Semper, foi herdado pelos gregos e na Hélade alcançou seu ápice: "Assim, Strukturschema e Kunstschema tornam-se idênticos e o pensamento orgânico, que mantém na Hélade seu emprego ideal na arquitetura, já é aqui manifestado em um modo real ".510 Assim como nas colunas assírias, também nas colunas dos templos gregos - sobretudo aqueles do tempo de Péricles -, responsáveis pela sustentação da cobertura, é possível notar que decoração e estrutura estão unidas. A estrutura está visível e é decorada pelos

\footnotetext{
509"Wie jene verpuppten oder mumisirten Säulen mit Knospenkapitäl, sind auch sämmtliche Mauern, demselben Prinzipe gemäss, gleichsam in Teppiche total eingewickelt; der steinerne Kern als solcher, als Struktur nämlich, tritt nicht zur Erscheinung, fungirt auch nicht anders als insoweit er sich selbst aufrecht erhält und fest ist...". Ibid.,pp.422-423

510 "So werden Strukturschema und Kunstschema identificirt und der organische Gedanke, der in Hellas seine ideale Anwendung in der Baukunst erhält, ist hier schon in realer Weise ausgesprochen". Ibidem, p.390.
} 
os ornamentos, os quais são ou pintados diretamente na pedra, ou, quando são esculpidos nela são em seguida pintados, o que indica que, de modo semelhante ao Estilo assírio, "o Estilo arquitetônico grego não conhece nenhuma diferença entre 'Kernschema' e 'Kunstschema'. ${ }^{511}$ E o revestimento decorativo, que nos assírios era em metal, nos gregos passa a ser somente "a cor, o mais sutil e incorpóreo revestimento". 512

Essa é a grande mudança conquistada pelo Estilo grego, pois ter somente a cor como revestimento, implica que, segundo Semper, o templo helênico,

é libertado de seus propósitos materiais, e somente aparece como portador do pensamento formal, enquanto este, ao mesmo tempo através da dissimulação das juntas da pedra, sobretudo do material construtivo, de certo modo se emancipa deste último [do material]. ${ }^{513}$

O revestimento grego, segundo Semper, consistia em um fino véu transparente, uma espécie de verniz, ${ }^{514}$ que permitia que a cor do mármore por trás reluzisse através e aparecesse como que misturada às cores do revestimento, dependendo da distância de observação e do brilho dos raios do sol. ${ }^{515}$ Logo, emancipar-se da matéria não quer dizer prescindir do material, ele não somente atua em uma espécie de jogo de mostrar-se e esconder-se por trás do referido véu, contribuindo com a aparência final, como também é responsável por condicionar a forma, consistindo, deste modo, na "chave" para compreendêla:

o material é negado somente em um certo sentido, a saber, em sua aparência material enquanto tal, em sua específica naturalidade e cor, as quais não são utilizadas como meio para a decoração; mas, ao mesmo tempo, ao criar a forma, precisamente para esquecer o material, [é que] suas características devem ser tomadas em conta. Assim, o material

\footnotetext{
511“...kennt der griechische Baustil keinen Unterschied zwischen 'Kernschema' und 'Kunstschema”. Ibid., p.444.

512 “...die Farbe, als die subtilste körperloseste Bekleidung [...]”. Ibid., p.445, grifo do autor.

513" Der hellenische Tempel [...] ihrem materiellen Dienste befreit wird, und nur als Trägerin des formalin Gedankens auftritt, während sie diesen zugleich durch das Verstecken der Steinfugen, des Baustoffes überhaupt, von letzterem gleichsam emancipirt...". Id.lbid., pp.443-444.

514 Isso porque, para o autor, ele era resultado da técnica da encáustica.

515 Quanto às considerações de Semper acerca da policromia grega, conferir os seguintes escritos deste autor: Vorläufige Bemerkungen über bemalte Architectur und Plastik bei den Alten, op.cit., On the study of polychromy and its revival (In: FALKENER, Edward. The museum of classical antiquities: a quarterly journal of architecture and the sister branches of classic art. London: John W. Parker and Son,1851, pp.228-246) $e$ Die vier Elemente der Baukunst, op.cit., capítulos1-4.
} 
tornou-se, por assim dizer, a chave para a compreensão da forma... ${ }^{516}$

Na medida em que "o princípio grego é aquele o qual mais se emancipou da necessidade da natureza", ${ }^{517}$ pode-se dizer que a arquitetura grega, é aquela em o Ornamento cumpre seu papel mais elevado, um papel que deveria ser perseguido na contemporaneidade, aquele de "fazer da necessidade uma virtude" 518

\subsection{Ornamento como símbolo estrutural da Arquitetura}

Karl Bötticher não somente postulou que a ornamentação deveria surgir da estrutura e decorá-la, mas também estabeleceu que se tratava de uma relação simbólica, que seguia as leis da natureza:

- princípio da tectônica helênica é comprovadamente inteiramente idêntico ao princípio da natureza criadora: manifestar na forma o conceito de cada criação. Deste princípio único surge uma lei da forma, a qual coloca-se bem acima da arbitrariedade individual do sujeito atuante, dentro de seus limites admite somente a verdadeira e maior liberdade e abre uma fonte inesgotável de invenção. ${ }^{519}$

Essa lei da forma, responsável pela manifestação do conceito, evidenciase no sentido de que, se "a Kernform de cada parte é a diretriz mecanicamente necessária, estaticamente atuante; a Kunstform por outro lado [é] somente a característica esclarecedora da função", ${ }^{220}$ ou seja, para Bötticher, o propósito

\footnotetext{
516“...Der Stoff wurde nur in gewissem Sinne negirt, nämlich dessen materielles Hervortreten als solcher, in seiner spezifischen Naturwüchsigkeit und Farbe, die als Mittel der Dekoration nicht benützt wurden; aber zugleich musste, gerade um das Stoffliche vergessen zu machen, dessen Eigenschaften bei der Formgebung volleste Rechnung getragen werden. So blieb der Stoff gleichsam der Schlüssel zu dem Verständnisse der Form....". SEMPER, Der Stil, vol.I, op.cit.,p.448.

517"Das Grieschiche Prinzip ist dasjenige welches sich am moisten von der Naturnothwendigkeit emancipirte". SEMPER, Exzerpte und Notizen zu Böttichers "Tektonik der Hellenen", Manuscrito n.150, Semperarchiv an der ETH Zürich, 1853, fol.I. O conteúdo deste manuscrito foi retirado da transcrição do mesmo constante na obra de Michael Gnehm, Stumme Poesie, op.cit.,pp.206-9.

${ }^{518}$ Conferir capítulo 3, nota 476.

519" Das Princip der hellenischen Tektonik ist nachweisbar ganz identisch mit dem Principe der schaffenden Natur: den Begriff jedes Gebildes in seiner Form auszusprechen. Aus diesem Principe allein entspring ein Gesetz der Form, welches hoch über der individuellen Willkühr des werkthätigen Subjektes steht, innerhalb seiner Gränzen die allein wahre, die hochste Freiheit einschließt und der Erfindung eine unversiegbare Quelle eröffnet'. BÖTTICHER, Die Tektonik der Hellenen, 1852, vol.I, op.cit., p.XIV.

520 "Die Kernform jedes Gliedes ist das mechanisch nothwendige, das statisch fungirend Schema; die Kunstform dagegen nur die Funktion-erklärende Charakteristik”. Id.Ibid., p.XV.
} 
da Kunstform seria o de representar simbólica e artisticamente a atividade estática que corresponde a cada membro estrutural. ${ }^{521}$

A constatação por Bötticher de que, nas teorias estéticas, "a percepção subjetiva da arte e da natureza havia separado a essência mecânica da Arquitetura de seu simbolismo artístico", ${ }^{522}$ leva o autor a postular que o Ornamento, ao invés de atender ao livre curso da imaginação e contribuir para a superação do viés utilitário da edificação, deve se firmar em uma relação de complementaridade com tais atributos mecânicos, ou seja, ele deve ser tratado como símbolo construtivo destas partes.

Para esclarecer melhor suas ideias, em Die Tektonik Bötticher apresenta ilustrações dos ornamentos dos templos gregos, por exemplo, daqueles presentes no cima dórico, ou nos perfis das bases das colunas, e procura demonstrar como estes ornamentos, mediante seus diferentes graus de curvatura, assinalam os conflitos de forças atuando naquela parte (figuras 43 a 45).

O fato de grande parte destes ornamentos ilustrarem estilizações de padrões de folhagens reforça a analogia orgânica com a natureza, uma vez que os distintos tipos de curvatura dos perfis de certo modo dramatizam a reação da "força vital da planta" às cargas que atuariam sobre ela, como ocorria entre esta força vital e a própria força da gravidade no mundo vegetal. A intensidade da carga é diretamente proporcional à curvatura do perfil ornamental - este é um dos fundamentos do simbolismo construtivo de Bötticher e o sentido da linguagem arquitetônica para ele. Segundo Mallgrave, "o importante para Bötticher é que toda linha se torna uma metáfora, e atrás de toda forma há uma tectônica elaborada e um propósito artístico". ${ }^{523}$

\footnotetext{
521 Id.Ibid. Segundo o autor, a decoração é tomada "como o que ela na realidade somente deve ser, como envoltória, conceito simbolizante perante os olhos do verdadeiro núcleo atuante". Tradução nossa de "...[Dekoration] als das was sie in der That nur sein soll, als Begriff-symbolisirende Hülle des wirklich fungirenden Kernes vor Augen". Ibid., p.8, grifo do autor.

522 "[In aesthetics], the subjective perception of art and nature separated architecture's mechanical essence from its artistic symbolism". SCHWARZER, Ontology and representation in Karl Bötticher's theory of tectonics, op.cit., p.267.

523 "The important thing for Bötticher is that every line becomes a metaphor, and behind every form there is an elaborate tectonic and artistic purposiveness". MALLGRAVE, Harry Francis. Animism, empathy and ornament in XIXth century Germanic theory. In: VARELA, Ariane Varela (org.) Ornamento, tra arte e design. Interpretazioni, percorsi e mutazioni nell'ottocento. Basel: Schwabe Verlag, 2013, p.65.
} 


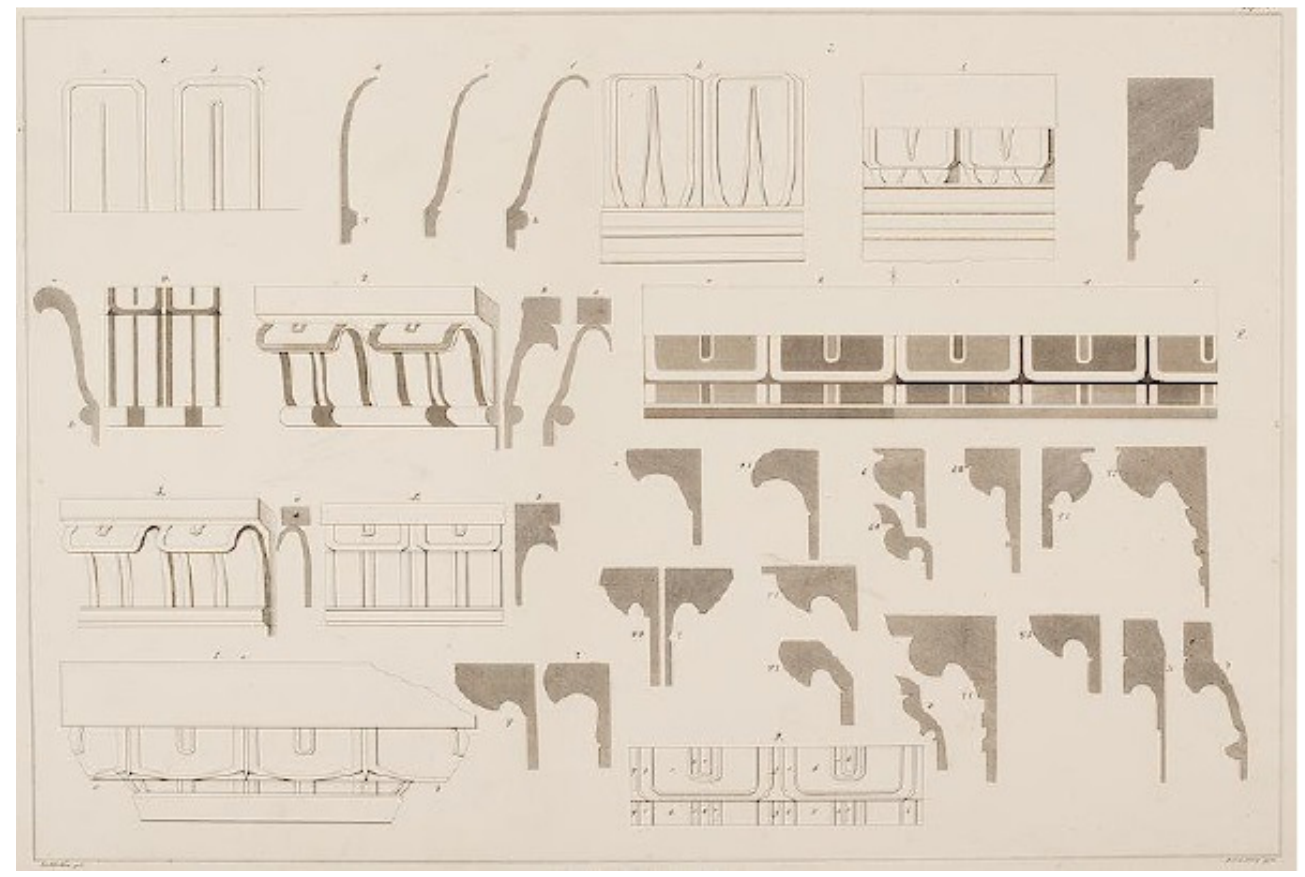

Figura 43 - Perfis de cima indicando tipos de carregamento. Fonte: BÖTTICHER, Die Tektonik der Hellenen, vol.I.,1852.

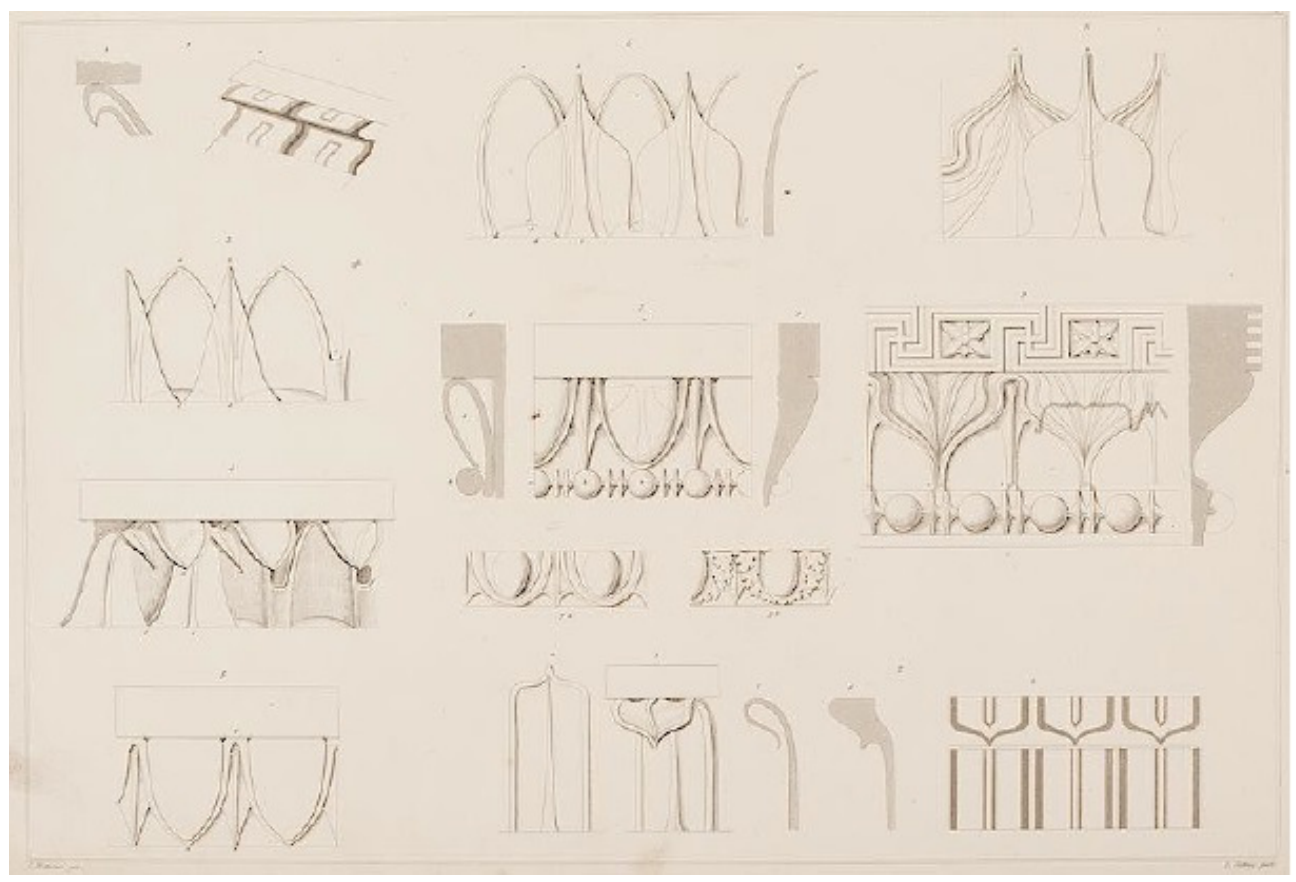

Figura 44 - Tipos de óvalo-e-dardo e folha-e-dardo, em vista e em perfil. Fonte: BÖTTICHER, Die Tektonik der Hellenen, vol.I, 1852. 


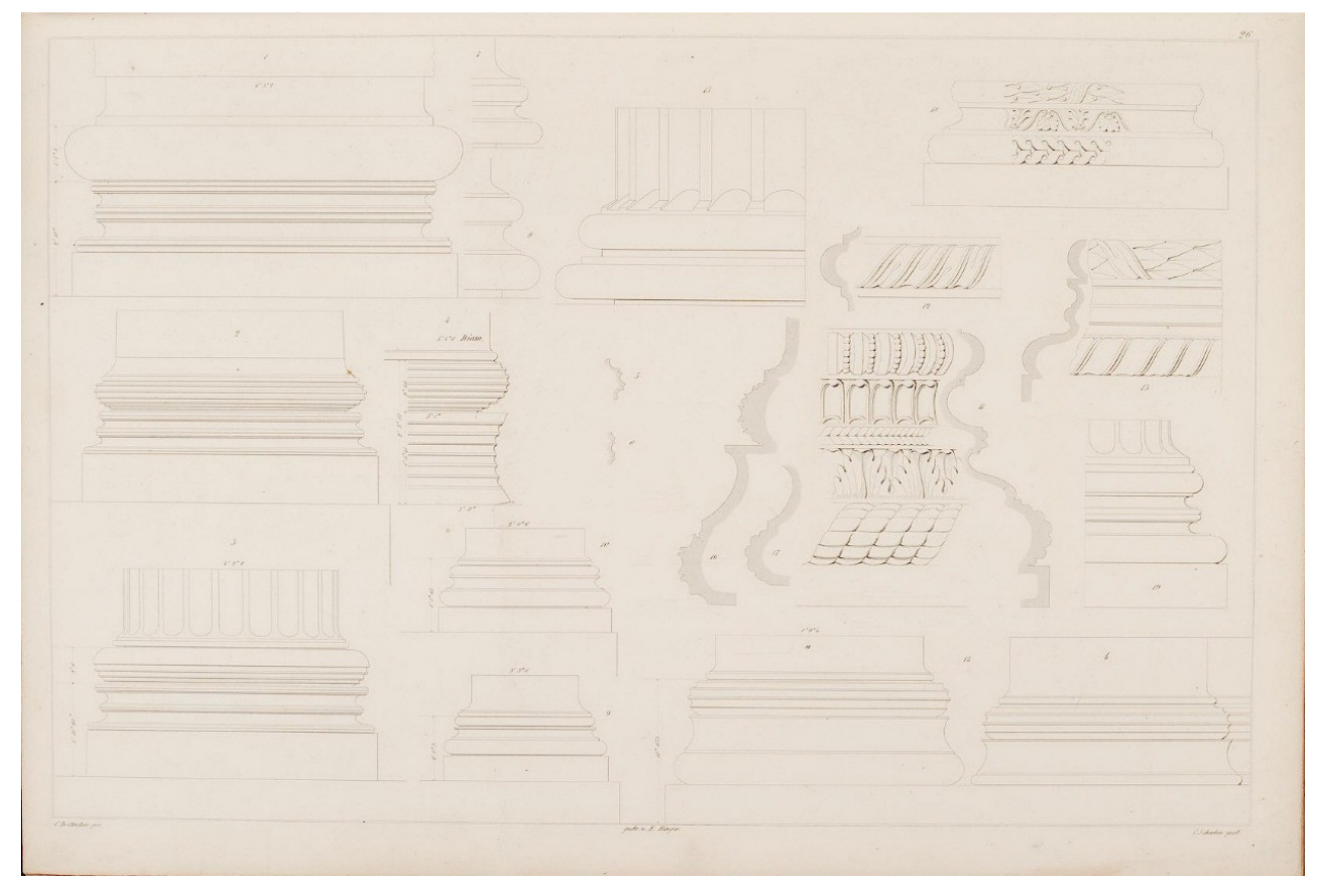

Figura 45 - Estudos das bases das ordens e das curvaturas dos perfis, considerando as forças de compressão a que são submetidas. Fonte: BÖTTICHER, Die Tektonik der Hellenen, vol.I, 1852.

Pode-se notar que Semper se referencia em parte das ideias de Bötticher ao classificar como "símbolos estruturais" os Ornamentos que expressam os conflitos de forças atuando em cada membro ou parte estrutural da edificação. ${ }^{524}$ Segundo o autor do Der Stil, tais símbolos foram muito explorados pelos gregos e muitos deles "foram tirados ou derivados de analogias na natureza e [eram] auto-compreensíveis para qualquer um que tem alguma intuição da natureza e da significação dinâmica das formas naturais". ${ }^{525}$ Eles pressupõem que "uma parte da construção supõe-se estar recebendo carga"526 e que, por sua resistência, esta parte é capaz de resistir a esta carga.

\footnotetext{
524 Sobre o sistema de forças que Semper reconhece em todo fenômeno, conferir capítulo 2. Mitchell Schwarzer e Harry F. Mallgrave postulam que uma das prováveis referências tanto de Bötticher, quanto de Semper - que o seguiu - nesta ideia de a arquitetura seguir as leis mecânicas da natureza foi Arthur Schopenhauer, sobretudo sua obra "O mundo como vontade e como representação". Segundo Schwarzer, "na estética de Schopenhauer, a tarefa da arquitetura era desdobrar a 'Ideia' da matéria rígida. Utilizando o templo grego como seu principal exemplo, Schopenhauer descreveu a coluna e o entablamento como elementos coincidentes da expressão arquitetônica de gravidade, rigidez, solidez e peso". Tradução de "In Schopenhauer's aesthetics, the task of architecture is to unfold the 'Ideia' of rigid matter. Using the Greek Temple as his principal example, Schopenhauer described the column and entablature as coincident elements of the architectural expression of gravity, rigidity, hardness and weight'. SCHWARZER, Ontology and representation in Karl Bötticher's theory of tectonics, op.cit., p.270. Conferir também MALLGRAVE, Animism, empathy and ornament in XIXth century Germanic theory, op.cit., pp.59-72.

525 "[...most of the symbols employed] were taken or derived from analogies in nature and self-understandig for every one who has some feeling for nature and the dynamical signification of natural forms". SEMPER, On architectural symbols, op.cit., p.63.

526 “... a part of the construction is supposed to be burdened..... Id.Ibid., p.64.
} 
Semper reitera a ideia do colega de que é pela curvatura dos perfis dos Ornamentos que se observa essa resistência à carga, sobretudo naqueles que seguem padrões de folhagem (figuras 46 e 47). Segundo o teórico hamburguês, "quando mais carregadas, as folhas irão curvar-se mais ainda e inclinar para suas raízes ou para a faixa pela qual supõe-se que elas estejam fixas na parte estrutural". ${ }^{527}$ Acrescenta ainda que, pela variação das linhas dos perfis, que podem ser infinitas - dependendo da quantidade de carga atuando -, é possível combinar diferentes escalas de proporção dos materiais de construção adequadas a cada tipo de carga. ${ }^{528}$ Nota-se aqui, nesta tentativa de associar 0 Ornato a padrões de proporção que exibiriam o aspecto ou aparência de solidez da edificação, certa afinidade ao antigo princípio vitruviano da firmitas. ${ }^{529}$

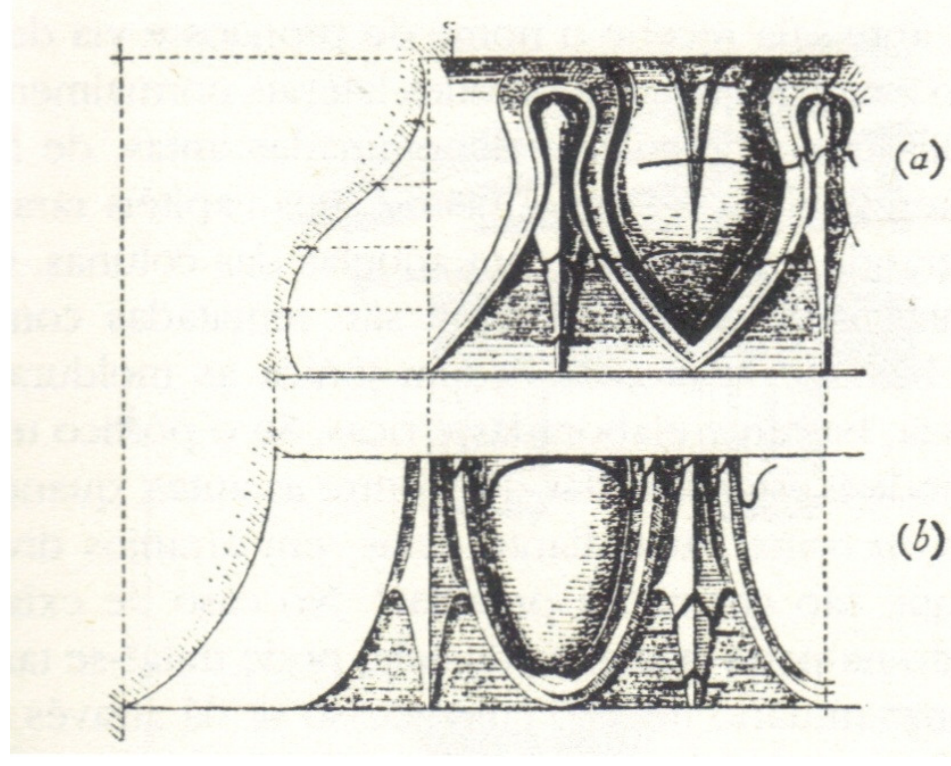

Figura 46 - Perfis de curvatura dupla (a) e de curvatura simples (b). Motivos folha-e-dardo (a) e óvalo-e-dardo (b). Fonte: ROBERTSON, D.S., Arquitetura grega e romana, 2014.

\footnotetext{
527“"when more burdened, the leaves will still more bend and incline to their roots or to the band by which they are supposed to be fastened on the structural part'. Id.Ibid., p.64.

528 "A variação das linhas elásticas formadas pelas folhas curvadas é infinita e tão variada quanto a expressão que nós somos capazes de dar à parte em que o ornamento é aplicado, com respeito a sua função estática. Por este caminho nós podemos ter os meios de ajustar nossas proporções materiais das partes estruturais para qualquer modo musical ou melhor, arquitetônico. " Tradução de "The variation of the elastic lines formed by the bending leaves is infinite and as manifold as the expression which we are enabled to give to the part on which the ornament is applied, with respect to its statical function. By this way we shall have the means of tuning our material proportions of the structural parts, for any intended musical or rather architectural mode whatever". Id.Ibid., p.64.

${ }^{529}$ Conferir capítulo 1.
} 


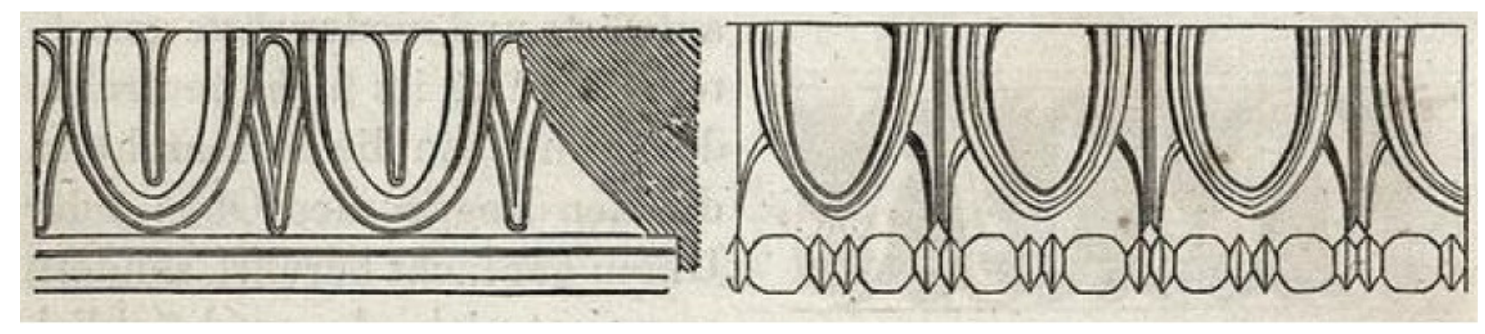

Figura 47 - Tipos de folha-e-dardo (esq.) e óvalo-e-dardo com contas de rosário (dir.). Desenhos de Semper. Fonte: SEMPER, Der Stil, vol.I, 1860.

Apesar da referência em Bötticher, Semper contrapôs-se a várias ideias do colega que iam de encontro a sua concepção do Estilo e que demonstram divergências entre os dois teóricos quanto a uma teoria tectônica, sobretudo no que se refere ao Ornamento. Foram estas discordâncias conceituais que permitiram a Semper amadurecer sua concepção sobre o Ornato. Uma delas refere-se à própria origem da Tectônica.

Se para Bötticher a Tectônica é exclusivamente helênica, criação autóctone do solo grego e originária da pedra, para Semper ela é originária da técnica têxtil, reconhece modificações de materiais ocorridas por motivos diversos em detrimento da permanência de certos traços formais e não é restrita às produções artísticas dos gregos. O teórico hamburguês inclusive, como se observa em seu discurso, é um grande opositor da ideia da autoctonia das criações helênicas ${ }^{530}$ - noção difundida a partir dos escritos de Winckelmann ${ }^{531}$ -, em seus escritos, para ele, todas elas são o resultado de empréstimos e heranças de outros povos, como é o caso do revestimento.

Outra divergência é quanto à origem das formas. O autor de Die Tektonik sustenta que a forma surge do conceito, ou seja, todo fenômeno natural, toda forma da natureza, é a expressão de um conceito, uma ideia interna que deve estar aparente no fenômeno. No entanto, aí é que Semper observa uma das contradições da teoria do colega, pois, Bötticher, ao reconhecer o Ornato como

\footnotetext{
530 Semper sustenta que "a cultura helênica só poderia ter surgido do húmus de antigas condições há muito mortas e desintegradas e de motivos estrangeiros trazidos de fora e que não são mais compreensíveis em seu significado original". Tradução de "Hellenische Bildung konnte nur auf dem Humus vieler längst erstorbener und verwitterter früherer Zustände und fremder von Aussen herübergetragener in ihrer ursprünglichen Bedeutung nicht mehr verstandener Motive entstehen". SEMPER, Die vier Elemente..., op.cit., p.52.

531 Winckelmann, ao discorrer sobre o surgimento da arte na Grécia declara que "os gregos, em vez de terem tomado o gérmen dos outros povos, podem perfeitamente ser considerados seus inventores, e o cultivaram como uma planta natural do país". Traução de "...los griegos, en vez de haber tomado el germen de los otros pueblos, pueden ser considerados perfectamente como sus inventores, y lo han cultivado como uma planta natural del país". WINCKELMANN, Johann Joachim. Historia del arte en la Antigüedad, op.cit., p. 123.
} 
conceito simbolizante daquilo que é real, acaba, de certo modo, por deslegitimar a efetiva necessidade da decoração, ainda mais porque as partes estruturais são capazes por si mesmas de executar suas atividades estruturais. Bötticher afirma:

desta maneira a forma externa, através da função viva e da essência interna, é formada [...]: assim a tectônica pode produzir a expressão que revela tal essência e atividade mecânica na exterioridade de seus corpos representados, pelo material morto e inorgânico do qual ela forma estes corpos, nada diferente de aparente e, por assim dizer, como formado e aplicado de fora. ${ }^{532}$

Apesar do autor de Die Tektonik sustentar a indissociabilidade entre a Kunstform e a Kernform, inclusive esclarecendo que ambas são concebidas ao mesmo tempo no intelecto, ${ }^{533}$ seu discurso dá margem à interpretação de uma separação de ambas:

segundo tal perspectiva, a Tectônica antiga procede com sentidos muito autênticos, já que ela separa bem perceptivelmente o revestimento decorativo do núcleo, como [algo] construtivo não necessário, do construtivo e necessário volume do núcleo, e ela representa como [se fosse] aplicado ou acrescentado de fora. ${ }^{534}$

À explicação da origem de toda forma em um conceito, por exemplo, Semper contrapõe o argumento de que "o princípio mecânico do membro não é concebido, mas sim surge da necessidade". 535 Por outro lado, na reflexão semperiana, não é só o Ornato que é simbólico, então, questiona Semper, em Die Tektonik, por que "o autor separa a Kernform da Kunstform pelos detalhes, por que não também pelo todo da estrutura [?]". ${ }^{536}$ Toda forma é simbólica, o que tornava o conceito de Bötticher questionável. Deste modo, o Ornamento não é o

\footnotetext{
532"... auf diese Weise durch die lebendige Funktion und innere Wesenheit die äußere Form in lebensthätigem Ausdrukke [wird] gebildet [...] : so kann die Tektonik einen solchen Wesenheit und mechanische Thätigkeit verrathenden Ausdrukk in den Äusserlichkeiten ihrer darstellenden Körper, bei dem todten anorganischen Materiale woraus sie diese Körper bildet, nicht anders als scheinbar und gleichsam als von außen angebildet oder angelegt erzeugen". BOTTICHER, Die Tektonik...op.cit., pp.7-8.

${ }^{533}$ Segundo o autor, ".... pensamento em ambos é um só, ambos nasceram juntos. O conceito de cada parte somente torna-se evidente com sua manifestação em fenômeno [...] já que toda materia manifesta-se através de uma animação dos pensamentos". Tradução nossa de "...der Gedanke an beide ist Eins, sie werden beide mit einander geboren. Erst mit ihrer Erscheinung wird der Begriff jedes Gliedes offenbar, [...] da ja jeder Materie [...] durch Gedanken Belebtes erscheint'. Id. Ibid., p.XV.

534 "nach solcher Ansicht verfährt die antike Tektonik mit sehr richtigem Sinne so, daß sie die decorative Bekleidung des Kernes, als struktiv nicht nothwendig, von dem struktiv nothwendigen Kernvolumen desselben, ganz wahrnehmbar sondert und sie wie angelegt oder von außen angefügt darstellf'. Id.Ibid., p.8.

535“...das mechanische Schema des Gliedes wird nicht koncipirt, sondern geht aus der Nothwendigkeit hervor". SEMPER, Exzerpte und Notizen zu Böttichers "Tektonik der Hellenen", op.cit., fol.I.

536" Der Verfasser trennt die Kernform von der Kunstform bei den Details, warum nicht auch bei dem Ganzen der Träger". Id.lbid., fol.I.
} 
único responsável pelo sentido das obras, como é possível perceber em uma definição que Semper apresenta ao tratar dos símbolos arquitetônicos: para o autor, os ornamentos consistem em "investimentos simbólicos da estrutura nua, com a ajuda dos quais nós damos um significado mais elevado, expressão artística e beleza a esta última [Arquitetura]". ${ }^{537}$

Outra divergência está justamente na questão dos sentidos evidenciados por estes símbolos estruturais. Como em Bötticher a decoração representada por tais símbolos é tomada "como o que ela na realidade somente deve ser, como envoltória, conceito simbolizante perante os olhos do verdadeiro núcleo atuante", ${ }^{338}$ o autor pressupõe a Arquitetura como uma arte autônoma, autorreferente, pois os significados que ela gera não se referem a nada externo a si mesma, mas sim, a suas próprias características mecânicas e construtivas. Já Semper critica este posicionamento, acrescentando sua convicção de que "as partes de uma obra de arte arquitetônica justificam-se como partes materiais da construção não somente por seu significado real ou simbólico, mas possuem também significado tradicional e histórico". ${ }^{539}$ Ou seja, Semper reconhece que esses símbolos possuem um propósito interno, o de apontar para as cargas atuantes, mas eles também e, principalmente, remetem a um propósito externo mais elevado, a uma ideia. Trata-se dos sentidos que os tipos ornamentais assumem em cada cultura e que dependem também dos fatores externos do Estilo, como da destinação da obra. O autor cita como exemplo o tratamento que os gregos deram a seus símbolos estruturais:

por exemplo, eles pegavam para a moldura, cuja função estática, como uma faixa ou amarração, era frequentemente simbolizada por uma coroa de folhas, diferentes tipos de folhas, de acordo com as diferentes destinações da edificação à qual a moldura pertencia. As folhas de louro pertenciam a Apolo, folhas de vinho a Baco, as folhas de mirto a Vênus, etc. Os caracteres das folhas eram diferentes, mas as significações estáticas gerais dos símbolos mantiveram-se inalteradas. ${ }^{540}$

\footnotetext{
${ }^{537}$ Conferir nota 490, grifos nossos.

538 "...[Dekoration] als das was sie in der That nur sein soll, als Begriff-symbolisirende Hülle des wirklich fungirenden Kernes vor Augen". BÖTTICHER, Die Tektonik..., op.cit., p.8, grifos do autor.

539"Die Theile eines architectonischen Kunstwerkes erklären sich nicht blo $\beta$ aus ihrer reellen oder symbolischen Bedeutung als materielle Theile der Construction, sondern haben auch traditionelle und historische Bedeutung". SEMPER, Exzerpte und Notizen zu Böttichers "Tektonik der Hellenen", op.cit., fol.I. 540 "For instance, they took for the moulding, whose statical function, as a band or a tie, was often symbolized by a wreath of leaves, different kinds of leaves, according to the different destinations of the building to which the moulding belonged. The laurel leaves belonged to Apollo, wine leaves to Bacchus, mirth leaves to Venus, etc. the characters of the leaves were different, but the general statical significations of the symbols remained unaltered'. SEMPER, On architectural symbols, op.cit., pp.63-4.
} 
Além disso, Semper, diversamente do colega, também defende que o colorido é parte fundamental do sentido destes símbolos. Para ele, as cores utilizadas nos templos gregos eram cores convencionais daquela cultura e não tinham um comprometimento com a fidelidade às cores da natureza, seu comprometimento é com facilitar a compreensão do propósito mecânico de cada parte. ${ }^{541} \mathrm{O}$ teórico sustenta que "uma obra de arquitetura não pode ser pensada e compreendida em seus verdadeiros sentidos sem seu apropriado complemento de cores". ${ }^{542}$ No entanto, consoante expõe Mallgrave, diferentemente de Bötticher e procurando reafirmar que a ornamentação helênica se emancipou da dependência material em todos os aspectos, Semper sugere que o sentido estático que as cores reforçam não seria exatamente "uma transferência de uma carga gravitacional para baixo, mas um campo de força de resistência movendo-se para cima"543 (figura 48).

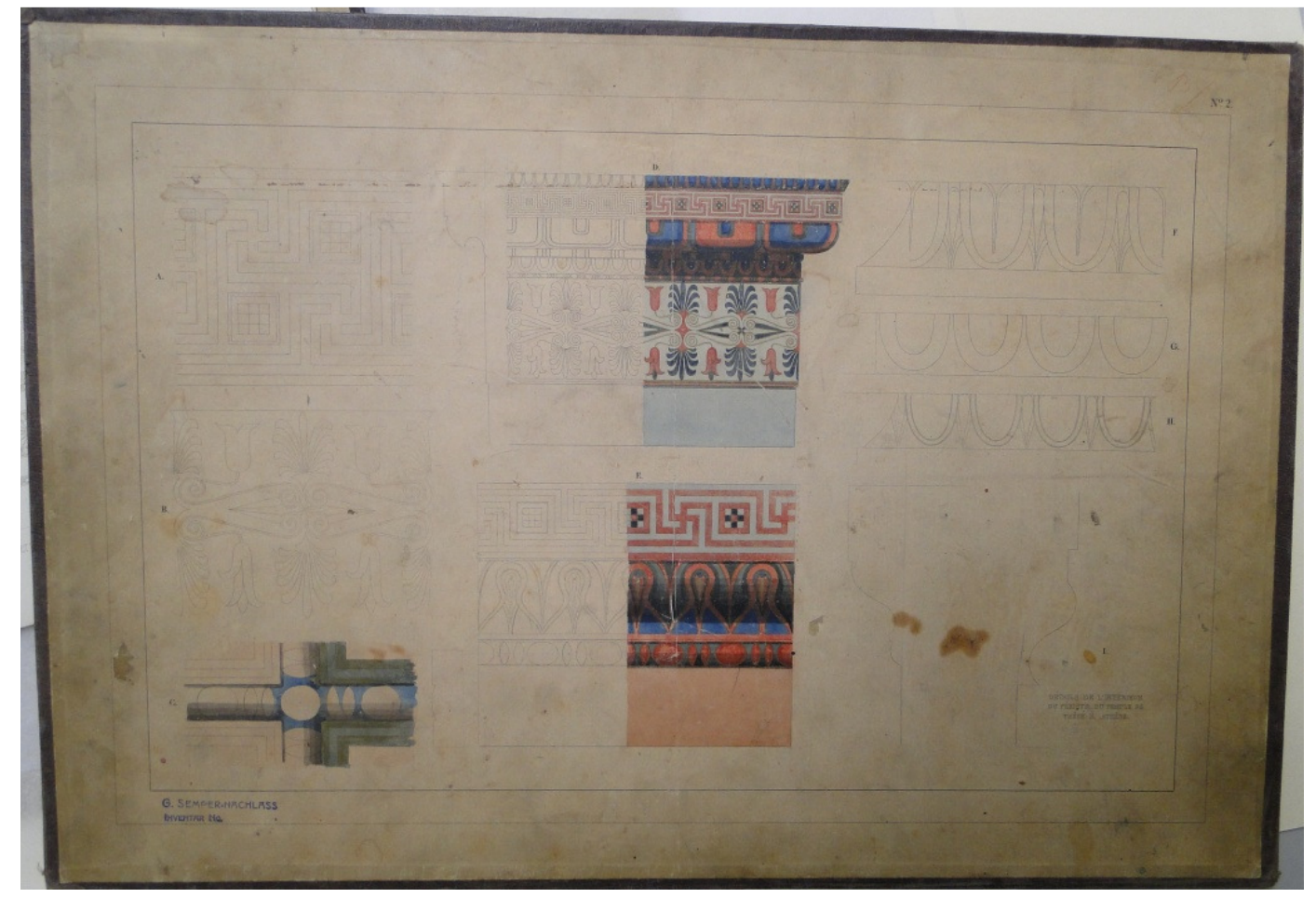

Figura 48 - Prancha de desenhos de Semper mostrando seus estudos da policromia clássica. Fonte: arquivo ETH de Zurique.

541 SEMPER, On architectural symbols, op.cit.

542 "Ein architektonisches Werk kann ohne seine richtige Farbenergänzung gar nicht in seinem wahren Sinne gedacht und aufgefasst warden..." SEMPER, Der Stil, v.I, op.cit., p.458.

543 "a transfer of a gravitacional load downward but as upward-moving force-field of resistance...". MALLGRAVE, Animism, empathy and ornament in XIXth century Germanic theory, op.cit., p.68. 


\subsection{Unidade entre beleza, aspectos estruturais e de utilidade}

$\mathrm{Na}$ análise dos Estilos egípcio, assírio e grego, Semper observa uma gradativa evolução. O egípcio, objeto da maior crítica do autor, é desaprovado não somente pela suposta separação, no revestimento, entre princípio construtivo e princípio artístico, mas sobretudo pelo caráter hierático e distante da natureza de sua decoração. Ao comparar esse Estilo com o dos assírios, o autor observa que enquanto nos egípcios as decorações das placas de pedra de seus monumentos mostram uma arte "embalsamada como uma múmia e assim completamente petrificada", 544 apresentando muitas vezes "signos caligráficos ou fórmulas convencionais de uma linguagem primordial lapidária, uma crônica pintada", 545 nos revestimentos assírios já é possível notar "por tudo uma aspiração em direção ao naturalismo", 546 em formas que "se apresentam e dão uma imagem mais ou menos bem feita de uma ação ou situação". ${ }^{547}$

Para Semper, a decoração egípcia, por exemplo, aquela encontrada nas pinturas murais ou aquela observada nos motivos vegetais das colunas (figuras 49 e 50), apresenta um simbolismo particular, dominado pela consagração religiosa, no qual os tipos em nada remetem à obra, a seus propósitos mecânicos internos, mas sim a valores externos, a saber, valores místicos e religiosos. Esses tipos exemplificam outra categoria de símbolo arquitetônico descrito por Semper, os símbolos tendenciosos ou místicos, que materializam determinado conteúdo religioso dos diferentes grupos culturais.

Consoante o autor, esses símbolos atuam remetendo "à destinação especial da edificação, ou ao Deus do templo e à religião dos fundadores", ${ }^{448} 0$ que evidencia que são símbolos convencionais, particulares de cada grupo cultural, e por isto, são compreensíveis somente para "aqueles que eram iniciados nos segredos da religião". 549 Em contraposição aos símbolos estruturais, conclui Semper, os tendenciosos não são de fácil e imediata

\footnotetext{
544 “...zur Mumie einbalsamirt und so gänzlich versteinert [wie in Aegypten]”. SEMPER, Der Stil, v.I, op.cit, p.359.

545“...[ägypitischen Bilder], kalligraphische Zeichen, konventionelle Formeln einer lapidarischen Urkundenschrift, gemalte Chronik". Id.Ibid., p.359.

546 “....bei alledem Naturwahre erstrebend...”. Id. Ibid., p.359.

547 “.... stellen jene assyrirscher Gestalten [...] sich selbst dar, geben sie das mehr oder weniger gelungene Bild einer Handlung oder einer Situation..." Id. Ibid., p.359.

548"...to the special destination of the building, or to the God of the temple and the religion of the founders" SEMPER, On architectural symbols, op.cit, p.63.

549 “...those who were initiated into the secrets of religion". Id.Ibid., p.63.
} 
compreensão. ${ }^{550}$ Qualquer indivíduo que tivesse um conhecimento da natureza e também certa noção de estática compreenderia os símbolos estruturais, já os símbolos tendenciosos, por sua vez, necessitam de um conhecimento prévio da religião, das lendas e dos mitos da cultura que os criou, não consistindo em uma linguagem universal, e, com isso, não seriam adequados para a época contemporânea..$^{51}$
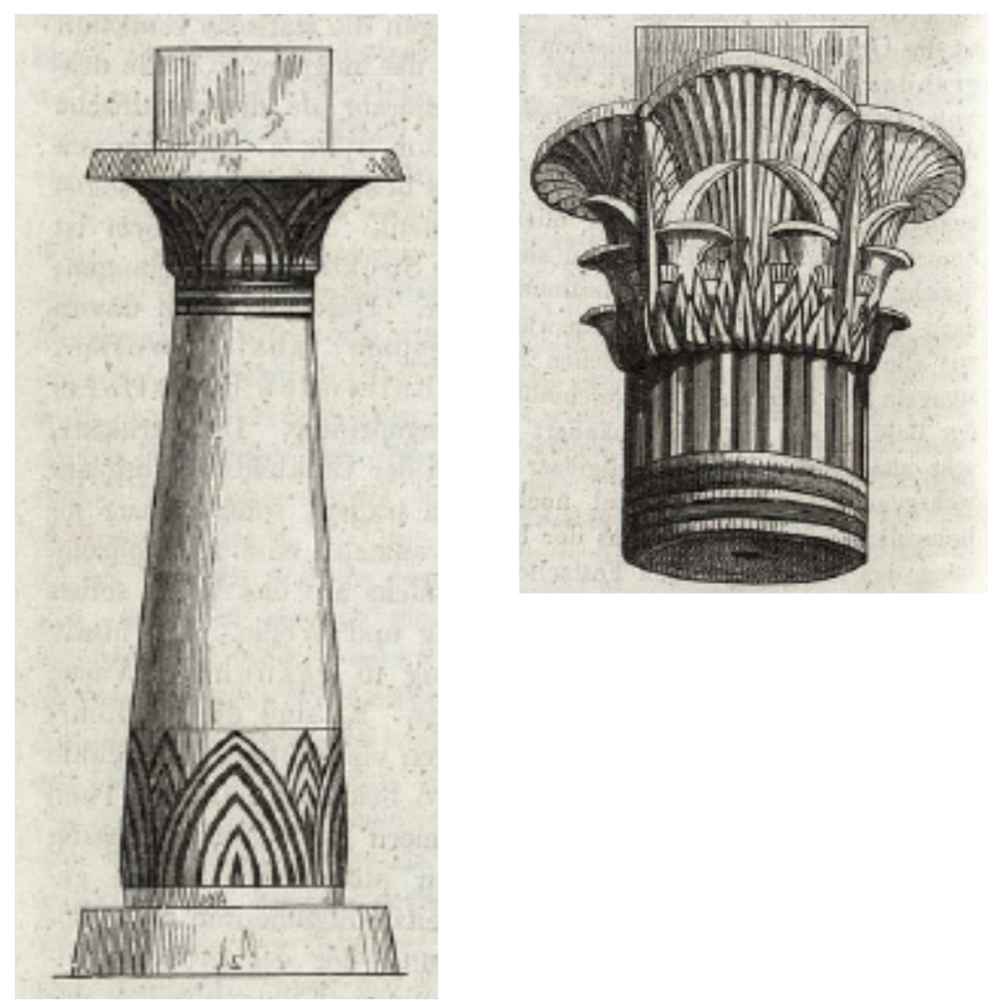

Figuras 49 e 50 - Coluna e capitel egípcios com motivos vegetais, desenhos de Semper. Fonte: SEMPER, Der Stil, vol.I, 1860.

A decoração egípcia do período faraônico é povoada por esse tipo de símbolo místico, acredita o autor. Nesta civilização, tais símbolos remetem à instituição religiosa - a qual era dominada por uma "aristocracia nacional hierática"552 - e a sua consagração. Como o revestimento monumental, enquanto princípio arquitetônico, caracteriza-se por ser um fenômeno coletivo da cultura, ${ }^{553}$ esta decoração, sustenta Semper, expressa justamente a dominação do indivíduo pela autoridade religiosa, ou seja, a submissão do individual no

\footnotetext{
550 SEMPER, On architectural symbols, op.cit. 551 Id. Ibid.

552“....hieratischen Landesaristokratie...”. SEMPER, Der Stil, vol.I, op.cit, p.406.

553 Conferir capítulo 2.
} 
coletivo, assim como a submissão das artes no coletivo. ${ }^{554}$ Nota-se nesta convicção a exemplificação do conceito de Estilo de Semper, no sentido de que o autor observa uma correspondência entre aspectos culturais, mais precisamente políticos, e expressão artística dos egípcios, abordagem adotada também no tratamento de assírios e gregos.

Nos caldeus-assírios, apesar de já ser possível observar casos em que o princípio artístico encontra-se unido ao estrutural, Semper considera que a arte e, consequentemente o indivíduo, assim como nos egípcios, ainda não estão totalmente livres, algo que ele conclui mediante a constatação do caráter e do duplo propósito que assume ali o Ornamento.

Por um lado, os tipos ornamentais deste povo, como nos egípcios, apresentam um significado místico ou religioso, expresso particularmente mediante a representação convencional de figuras de animais fabulosos ou bestas, que são também recorrentes em suas tapeçarias e decorações murais. ${ }^{555}$ Por outro lado, nas colunas, muitos destes tipos místicos, por analogia a determinadas funções que esses animais ou partes deles exercem no mundo real, remetem ao propósito do membro estrutural da edificação, mas sem indicar algum tipo de atuação orgânica das cargas, como ocorre na ornamentação dos gregos.

Segundo Semper, ocorre tanto nas colunas quanto no mobiliário assírios a situação de que "muitas costas de animais domesticados servem para carregar; é, portanto, disso compreensível que se dê aos membros de suporte uma vaga semelhança às costas de um animal"556 ou, no caso específico do mobiliário, os pés serem representados com patas de animais, fazendo uma alusão à mobilidade do artefato (figuras 51 e 52).

\footnotetext{
554 Consoante o autor, "a vida real do povo egípcio [...] teve que, todavia, com o progressivo crescimento do novo regime, gradualmente também aqui desaparecer e se submeter ao estilo hierático". Tradução nossa de "das eigentliche Volksleben Aegyptens [...] musste freilich mit fortschreitendem Wachsen des neuen régime allmälig auch hier verschwinden und dem hieratishen Stile unterliegen". SEMPER, Der Stil, vol.I, op.cit, p.406.

555 Conferir capítulo 2.

556 “...dient der Rücken mancher Hausthiere zum Tragen; es liegt daher nahe den tragenden Gliedern [...], eine entfernte Aehnlichkeit eines Thierrückens zu geben". Id.Ibid., p.387.
} 


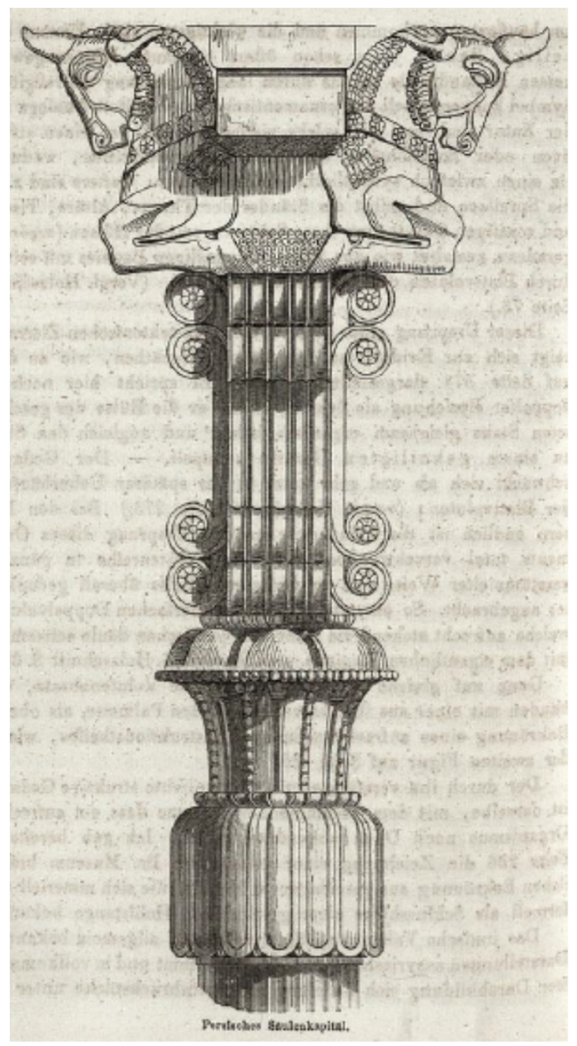

Figura 51 - Capitel de coluna persa, povo que deu continuidade à arte assíria, desenho de Semper. Fonte: SEMPER, Der Stil, vol.I, 1860.

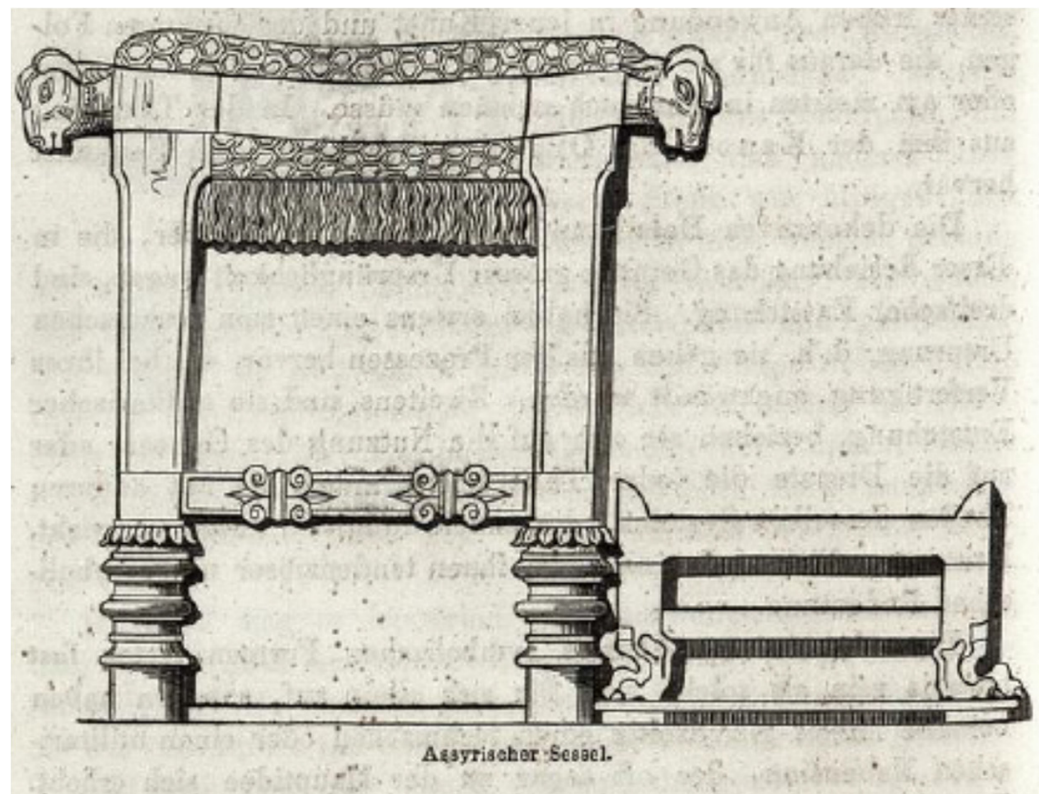

Figura 52 - Cadeira assíria, com formas aludindo ao dorso e às patas de animais, desenho de Semper. Fonte: SEMPER, Der Stil, vol.I, 1860. 
Somado a isso, nessas decorações assírias, tanto nas de parede quanto nas das colunas, as formas, segundo o teórico, ainda denunciam sua origem têxtil, pois a representação das figuras, por mais que demonstre um esforço em direção ao naturalismo, ainda é rígida e apresenta forte marcação das linhas, o que para Semper indica ainda estar presa à técnica do bordado. ${ }^{557}$ Logo, tanto o sentido tendencioso das figuras representadas quanto a representação destas figuras indicam para Semper que, assim como nos egípcios - mas em menor grau -, também nos assírios a arte e o povo se encontram submetidos a um sistema político marcado por uma aristocracia despótica. ${ }^{558}$

Nota-se que Semper observa uma relação inversamente proporcional entre dominação político-religiosa e liberdade do indivíduo, incluindo aí liberdade artística. $^{559} \mathrm{O}$ exemplo paradigmático utilizado por ele para ilustrar como egípcios e assírios vivem essa condição de submissão aos poderes religiosos e políticos é o modo como o local do fogo - local sagrado que teria se transformado no altar das instituições religiosas destas civilizações - é disposto nos monumentos. Nos principais monumentos desses dois povos, o templo egípcio e a pirâmide assíria, o ponto principal da construção, o foco espiritual que tudo governava, "perde seu significado próprio e [então] é glorificado não o deus, mas sim o poder daqueles que o estabeleceram". 560 Isto porque, segundo Semper, nos templos egípcios, formados por vários compartimentos, uns dentro dos outros, a divindade se encontra escondida em uma jaula atrás das várias paredes, em um "núcleo invisível", no qual "a idéia de hierarquia está encarnada". ${ }^{561}$ Nas pirâmides assírias, apesar da divindade estar ao ar livre, o fato dela estar elevada por uma poderosa subestrutura, no topo da pirâmide, evidencia como o homem, "em uma provocadora competição com as belezas da

\footnotetext{
557 lbidem.

558 Ibidem.

559 O que o leva a exaltar as expressões de períodos tidos como de menor dominação da lgreja, como o Renascimento italiano e a República francesa do século XIX. Em um manuscrito de seu período de exílio londrino ( "Remarks upon artistic taste among the people and the means of its development", Manuscrito n.89, Semperarchiv an der ETH Zürich, 1853, fol. 38-39), ele afirma que, no Renascimento, com a retomada da tradição dos antigos nas Repúblicas italianas, contrariamente aos efeitos da dominação anterior da Igreja, "a liberdade na escolha das formas dominou e produziu aquele repentino e miraculoso crescimento" ("...freedom in the choice of forms has held sway and produced that sudden and miraculous growth..."). Também durante a República na França no século XIX o teórico reconhece um grande avanço na indústria artística, que para ele (Ibid., fol.44) deve-se ao favorecimento da liberdade e do talento individual, o qual "não foi perturbado por uma influênia individual muito poderosa a qual antes era forçado a obedecer" (..."has not been disturbed by a too powerful individual influence which it before was forced to obey").

560 “... [in beiden] verliert er seine eigene Bedeutung, und nicht der Gott, sondern die Macht derer, die ihn setzen, wird verherrlicht'. SEMPER, Die vier Elemente..., op.cit., p.86, colchetes nossos.

561 "Die Idee der Hierarchie ist in ihm [unsichtbaren Kern] verkörpert". Id.Ibid., p.85.
} 
natureza, ousou imitá-las nos lugares em que elas estão ausentes", ${ }^{562}$ demonstrando, com isso, certa arrogância despótica.

No extremo oposto está o templo helênico. Na Hélade a edificação religiosa encontra-se a céu aberto, em um distrito chamado santuário, o qual está em uma subestrutura de pedra mais ou menos elevada e separada do resto da cidade por uma escadaria. O templo está em uma plataforma de altura moderada, com um pátio peristilar no interior, aos fundos do qual está a imagem da divindade. ${ }^{563}$ Ele "se sobressai acima do átrio para resplandecer em sua própria beleza, com seu frontão ricamente coroado, a casa de deus". ${ }^{564}$ Continua Semper:

sacerdotes espertos não mais mantém ela [a divindade] presa em uma gaiola escondida, ela não mais serve uma arrogância despótica alto nas nuvens como símbolo e imagem ameaçadora do próprio poder. Ela não serve ninguém, é o seu próprio propósito, uma representante da própria perfeição e da humanidade grega deificada nela. Somente um povo livre sustentado por um sentimento nacional pode compreender e criar tais obras. ${ }^{565}$

Para um povo livre, também a arte deve ser livre e expressar a vontade individual do artífice, ao invés de ter que se submeter a propósitos de consagração religiosa e de autoridade política. Para Semper, isto explica porque só na Grécia houve o pleno desenvolvimento das "artes elevadas" junto ao templo. Pintura e escultura só se desenvolveram ali porque havia condições políticas para tal e também porque só os gregos compreenderam o verdadeiro sentido da "cosmética pura". 566

Esse sentido da ordem cósmica, antes de ser aplicado na arquitetura helênica, se evidenciou nos adornos corporais desse povo, tanto na composição dos mesmos, quanto no modo como eles eram utilizados no corpo humano. Os

\footnotetext{
562 “...man sie [die Naturschönheiten], in trotzigem Wetteifer mit ihr, an Orten, wo sie fehlten, nazubilden wagte". Id. Ibid., pp.85-6.

563 Semper sugeriu que a forma do templo grego, uma cela com telhado e peristilo, por sobre uma estilóbata e no topo da Acrópole, teria vindo do encontro de características fenícias (cela com telhado e peristilo), somadas aos terraços assírios - que teriam referenciado o santuário helênico no topo da Acrópole e sobre uma estilóbata - e à forma linear e processional do templo egípcio. Cf. SEMPER, Die vier Elemente..., op.cit., capítulo 5.

564 “...ragt es über den ihm zur Verherrlichung in eigener Schöne prangende Hallen hinaus mit seiner reich gekrönten Giebel, das Haus des Gottes". Id.Ibid., p.93.

565 "Nicht mehr halten ihn kluge Priester in verborgenem Käfig gefangen, nicht mehr dient er despotischem Uebermuthe hoch in den Wolken als Symbol und Drohbild eigener Macht. Er dient Niemandem, ist sich selbst Zweck, ein Vertreter der eigenen Vollkommenheit und des in ihm vergötterten griechischen Menschenthumes. Nur ein freies von Nationalgefühl getragenes Volk kann solche Werke verstehen und schaffen". Ibidem, p.93.

566 “...reinen Kosmetik...” SEMPER, Über die formelle Gesetzmassigkeit des Schmucks..., op.cit., p.102.
} 
artefatos de embelezamento dos gregos eram formados por uma clara distinção entre jóia e engaste. $O$ engaste seria o que "atua mecanicamente, agarra, encadeia, une", ${ }^{567}$ é nele onde supostamente estariam as forças atuantes no artefato. Já a jóia é aquilo que é encadeado e preso pelo engaste, é o elemento que

está terminado em si mesmo, está suportado, e atua somente através de suas relações com as partes semelhantes - as partes visuais do adorno - e com o objeto adornado, não se manifesta conflito algum de forças construtivas mecânicas ativas nele. ${ }^{568}$

Em seu emprego no corpo humano do cidadão grego, esses adornos seguiam plenamente as leis da beleza formal - simetria, euritmia, proporcionalidade e direção $0^{569}$ - e eram aplicados ou nas terminações das partes, nas quais tinham o propósito de destacá-las - como em adornos usados nas cabeças, por exemplo - ou nas ligações entre as partes, em que também as destacavam, além de marcarem a ligação e a proporção entre elas, como colares, cintos ou pulseiras.

Semper acredita que só após explorar estes adereços no corpo humano eles foram empregados pelos gregos em sua arquitetura, seguindo a mesma ordem cósmica. A lógica que "anima" o corpo dos indivíduos pelo adorno - ao dissimular seu estado de natureza e conferir-lhe um estatuto de pessoa procede de modo semelhante na Arquitetura, que tem transcendida sua condição de matéria inerte. Nota-se que Semper reinterpreta, a seu modo, a associação clássica entre Arquitetura e corpo humano, e, segundo Günther Oesterle, ao sustentar que os adornos usados na Arquitetura são, de certo modo, uma espécie de imitação daqueles usados primeiramente no indivíduo, Semper atualiza para a época moderna, um princípio do classicismo estabelecido por Winckelmann e que é sugerido em sua (Semper) definição da palavra Cosmos, a saber, o princípio "segundo o qual o artista moderno não deve imitar a natureza, mas somente o que é o [seu] reflexo". 570 Ou seja, o artista moderno deve mirar o modo como as produções helênicas foram concebidas.

\footnotetext{
567“...es fungirt mechanisch, es fasst, verkettet, bindet...”. Id.Ibid., p.126.

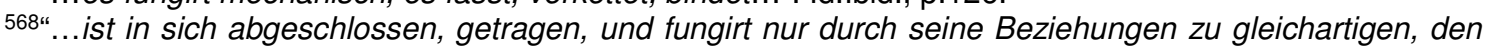
Schmuck bildenden Theilen, und zu dem geschmückten Gegenstande, es zeigt sich kein Conflict von mechanisch structiven Kräften in ihm thätig". Id.Ibid., p.126.

569 Conferir capítulo 2.

570 "...selon lequel l'artiste moderne ne doit pas imiter la nature mais seulement ce qui e nest le reflet..." OESTERLE, Günther. Gottfried Semper: la destruction et la réactualisation du classicisme. In: Revue
} 
Tanto a composição do adorno quanto o modo como ele foi utilizado no corpo humano foram reproduzidos na arquitetura helênica, acredita Semper. Primeiro, a distinção entre engaste e jóia aparece em uma clara diferenciação entre o Ornamento puro, ou seja, como símbolo estrutural, associado aos "tipos tomados das técnicas mais originária", ${ }^{571}$ como "as coroas e guirlandas, os bouquets, os cordões, cordas, colares, tranças e faixas," 572 - que por vezes pode apresentar certo conteúdo tendencioso, como a associação do tipo de folha ao Deus do templo - e a arte tendenciosa, que na verdade não se trata mais necessariamente de símbolos no sentido de serem tipos convencionais. São, de um modo geral, representações, que pressupõem um assunto e que nos gregos é arte livre, porque ali o artífice é livre para representar, na pintura e na escultura pintada, as histórias, lendas e mitos de seu povo. ${ }^{573}$

Nota-se que a evolução do revestimento decorativo entre os três povos antigos - na qual os antigos tapetes sofrem transformações técnicas e materiais até se tornarem pintura ou escultura pintada nos gregos - foi acompanhada por uma evolução nas representações das decorações destes revestimentos, na medida em que, se nos assírios já era possível se notar um empenho em direção ao naturalismo - mas nos quais "arte livre neles ainda não se desprendeu do Ornamento"574 - nos gregos tem-se um naturalismo consumado.

A jóia e o engaste têm seu paralelo na arte livre e no Ornamento puro e, assim como o engaste prende a jóia, também o Ornamento, como originariamente é têxtil, tem o propósito de ligar as representações de pintura e escultura às outras partes da edificação. Isto só ocorre porque também o modo como os Ornamentos são utilizados na Arquitetura segue ordem semelhante a do corpo humano. Como o Ornato amarra, encadeia e une, seu lugar são as

germanique international (trad. Klaus Briegleb), n.2, 1994, p.72. Neste texto, o autor se limita a citar dois principais pressupostos teóricos em que Semper destruiu e atualizou o classicismo, a saber, a negação do protótipo da cabana primitiva em madeira e a sugestão de imitação dos adornos dos gregos, ao invés da imitação direta da natureza.

571“...die der ursprünglichsten Technik entnommenen Typen...”. SEMPER, Über die formelle Gesetzmässigkeit des Schmuckes..., op.cit., p.127.

572“...die Kränze und gereiheten Blattgewinde, die Bouquets, die Schnuren, Stricke, Ketten, Geflechte und Bänder...”. Id., Ibid., p.127.

573 Segundo Semper foi no século V que as artes maiores alcançaram a perfeição na Grécia: "a pintura de parede, quer dizer, a verdadeira pintura histórico-monumental, alcançou, com transições, sua mais sublime direção, atráves de Polignoto e seus famosos contemporâneos". Tradução de "Die Wandmalerei, d.h. die eigentlich historisch-monumentale, erreicht nun mit Uebergängen am Ausgange dieser Stilperiode ihre erhabenste Richtung, durch Polygnot und seine berühmten Zeitgenossen". SEMPER, Der Stil, vol.I, op.cit., p.454.

574“Die freie Kunst hat sich an ihnen noch nicht aus dem Ornamente abgelöst”. Id.Ibid., p.386. 
molduras, os limites e terminações das partes ou as ligações entre uma parte e outra.

Entre Ornamento e arte livre há uma diferenciação orgânica de localização. Enquanto um é ativo mecanicamente e a outra passiva, o primeiro localiza-se nos lugares de atuação das cargas e a outra nos locais neutros, que nos templos seriam os tímpanos, as métopas e as paredes das celas. Segundo Semper, a arte de conteúdo tendencioso "pode e deve se desenvolver somente em um fundo neutro, que não funcione técnica e estruturalmente. ${ }^{" 575}$ Esta sintaxe formal já havia sido reproduzida em peças cerâmicas helênicas, nas quais os ornamentos encontram-se nas extremidades ou nas junções entre as partes, como entre o pescoço e a barriga do recipiente ou entre a barriga e o pé, e as representações pictóricas permanecem no espaço neutro da barriga (figura 53).

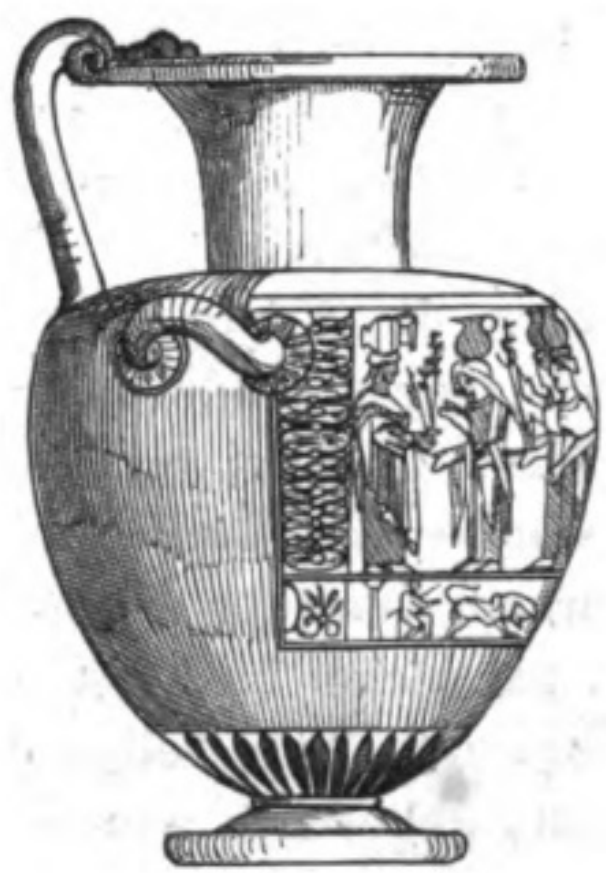

Eydria.

Figura 53 - Hídria grega, desenho de Semper. Fonte: SEMPER, Der Stil, vol.II, 1863.

O Ornamento empregado no templo grego, assim como aquele da cerâmica helênica e o que adorna o corpo do cidadão, segue as leis da beleza formal. Como exemplos apresentados pelo autor tem-se as gotas do

575“...nur auf neutralem, nicht technisch und struktiv funktionirendem Boden entfalten kann und soll'. Ibidem, p.86. 
entablamento dórico que são análogas aos brincos usados em ambos os lados das orelhas e reforçam a simetria; toros e astrágalos que cumprem o mesmo papel que os colares e apontam para a euritmia e a proporção entre as partes verticais; e o acrotério do templo que tem como análogo qualquer adorno marcando a cabeça e que aponta para a direção ou para o suposto sentido do movimento - um atributo tridimensional e corpóreo desconsiderado pelos estetas de sua época, avalia o autor. ${ }^{576}$ Estes três tipos de Ornamento não somente reforçam três princípios formais do templo, eles dão a ver essas relações e mostram como, nos monumentos religiosos helênicos, diferentemente daqueles dos egípcios e assírios, estes princípios da beleza estão em equilíbrio.

$\mathrm{Na}$ compreensão do teórico hamburguês, nas diversas obras arquitetônicas criadas pelo homem, as relações estabelecidas entre esses três princípios abstratos da beleza não são as mesmas, ora um é mais dominante, ora outro. A síntese dessas relações é caracterizada por Semper como o princípio da "autoridade de conteúdo" ou "unidade de propósito", 577 que seria o propósito maior da obra, distinto em cada sociedade. O autor esclarece que

os três princípios do adornar destacados devem contribuir com uma unidade de propósito no fenômeno adornado, ou seja, eles devem, em sua impressão conjunta, evidenciar e refletir, vantajosamente, sua própria natureza e caráter. ${ }^{578}$

No templo egípcio, sustenta Semper, há o prevalecimento do princípio de direção na medida em que a edificação, com o propósito de atender ao rito da procissão, se configura no sentido longitudinal. Na pirâmide assíria, predomina o princípio de simetria fechada reforçado pela massividade exacerbada das várias subestuturas que se encerram em si mesmas e coroam-se com o templo com a divindade no topo. O equilíbrio e a independência dos três fatores só são encontradas no templo helênico, características que o autor observa também na configuração do homem: "no templo grego, na sua mais completa riqueza e

\footnotetext{
576 Semper sustenta que a maior diferença entre sua concepção da beleza daquela dos estetas é que "eu compreendo a imagem das coisas corpóreamente, ou melhor, estereometricamente, enquanto a última [a dos estetas] aceita somente figuras planimétricas que, com a percepção das coisas, surgem como imagem". Tradução de "...ich das Bild der Dinge körperlich oder vielmehr stereometrisch fasse, während letztere sich nur auf die planimetrischen Figuren einlässt, die mit der Anschauung der Dinge als Bild entstehen". SEMPER, Über die formelle Gesetzmässigkeit des Schmuckes..., op.cit, pp.124-5, colchetes nossos. 577 Inhaltsautorität ou Zweckeinheit. SEMPER, Der Stil, vol.I, op.cit., p.XLII.

578 "Die drei bezeichneten Prinzipe des Schmückens müssen nun zweckeinheitlich an der geschmückten Erscheinung zusammenwirken, d.h., sie müssen in ihrem Gesammteindrucke das Wesen und den Charakter derselben vortheilhaft hervorheben und wiederspiegeln...". SEMPER, Über die formelle Gesetzmässigkeit des Schmuckes..., op.cit., p.115.
} 
maior liberdade, a unidade de propósito evidencia-se analogamente como no homem, [ou seja] na mais pura harmonia!". ${ }^{579}$ Algo que evidencia que, diversamente dos monumentos de egípcios e assírios, que estão a serviço do corpo coletivo enquanto Estado e instituição religiosa, o monumento grego atende à humanidade, ao homem enquanto indivíduo livre.

Como marca paradigmática do sentido de liberdade encarnado no templo helênico está o frontão do Partenon 580: "o frontão coroante de Atenas é, como o semblante da deusa, ao mesmo tempo o dominante da proporcionalidade, a quintessência da simetria e refletor da procissão sacrificial que se aproxima". ${ }^{581}$ O frontão reflete os ritos sacrificiais mediante as representações históricas e cênicas do tímpano, representações de pintura e escultura, "a mágica que afeta a alma através da arte em suas formas e manifestações mais variadas". 582

Enquanto símbolo estrutural, o Ornamento, conforme sua origem têxtil, sua aparência linear e sua localização na obra indicam, deve ser aquilo a que ele se propõe a ser, um elemento de ligação e de indicação do sentido estático da forma que ele decora. Enquanto forma embelezadora convencionalmente interpretada em cada cultura, ele deve esclarecer ao olhar as relações formais abstratas da obra arquitetônica e destacar as expressões artísticas mais elevadas, permitindo com isso, uma adequada correspondência ao propósito maior da obra, sua ideia. Quando tudo isso ocorre, como no caso da Grécia clássica, "permite-se que o belo formal apareça ao mesmo tempo bom e correspondente ao propósito"583 e tem-se aí, para o consagrado autor do Der Stil, a significação plena do Ornato arquitetônico, que deveria ser perseguida na época contemporânea.

\footnotetext{
579“...in dem griechischen Tempel tritt die Zweckeinheit analog wie bei dem Menschen, bei vollstem Reichthum und grösster Freiheit in reinster Harmonie hervor! SEMPER, Der Stil, vol..l, op.cit., p.XLIII.

${ }^{580} \mathrm{Na}$ analogia entre arquitetura e corpo humano, o frontão seria como a cabeça, a qual é "aquela parte que, por sua vez, metaforicamente representa o homem inteiro...". Tradução de "[das Haupt, als] derjenige Theil, welcher gleichsam den ganzen Menschen sinnbildlich repräsentirt..." SEMPER, Über die formelle Gesetzmässigkeit des Schmuckes..., op.cit., p.109.

Athene's krönendes Giebelfeld ist wie das Antlitz der Göttin zugleich die Dominante der Proportionalität, der Inbegriff der Symmetrie und der Reflektor des opfernd nahenden Festzuges". SEMPER, Der Stil, vol.I, op.cit., p.XLIII.

582 "Der Zauber der durch die Kunst in ihren verschiedensten Arten und Manifestationen auf das Gemüth wirkt...". Id.Ibid., p.XXIII.

583 "...lässt das Formell-Schöne zugleich als gut und zweckentsprechend erscheinen". SEMPER, Über die formelle Gesetzmässigkeit des Schmuckes..., op.cit., p.20.
} 


\section{CONSIDERAÇÕES FINAIS}

Quando Quatremère de Quincy, no verbete Caractère da última versão de seu Dictionnaire, critica os "gêneros de indústria barata" que "lançaram em circulação ornamentos que se tornaram insignificantes por sua própria multiplicidade", os quais "nada mais são que entulhamento fastidioso e que nos edifícios desempenham o mesmo papel que os bordados sobre os tecidos!", 584 Semper era ainda um jovem aspirante a arquiteto que, após alguns anos de estudo em Paris - anos que coincidiram com Quincy à frente da Académie des Beaux-Arts - se lançava na tradicional aventura de conhecer as terras clássicas.

Exatamente vinte anos após esta data, o arquiteto, já internacionalmente conhecido pela autoria do teatro de ópera de Dresden, divulga publicamente sua teoria do Estilo, 585 a qual visava confrontar o tal "entulhamento fastidioso" - que parecia ter alcançado seu cume com a Exposição industrial londrina de 1851 -, mas que, diversamente do pensamento do mestre francês, reconhece e assume os vínculos fundamentais que os ornamentos possuem com os bordados, e, de um modo geral, com os têxteis.

Por um lado, a teoria do Ornamento que Semper elabora põe em questão justamente o pensamento acadêmico que nas primeiras décadas do século XIX é tributário de Quincy, aquele no qual o Ornato arquitetônico, "uma camada anexada do mesmo material e realizada com as mesmas ferramentas da arquitetura", ${ }^{586}$ assim como esta última como um todo, era observado do ponto de vista da escultura, ou seja, deveria ser monocromo, seguindo um modelamento de luz e sombra. ${ }^{587}$ Certamente motivado por investigações no

\footnotetext{
584 "Não se saberá dizer quantos diferentes gêneros de indústria barata se multiplicaram sob toda sorte de materiais e lançaram em circulação ornamentos que se tornaram insignificantes por sua própria multiplicidade. Quantas esfinges, leões, águias, vasos, troféus, candelabros, trípodes, altares, caduceus, aljavas, coroas, ramos de louros etc. que nada mais são que entulhamento fastidioso e que nos edifícios desempenham o mesmo papel que os bordados sobre os tecidos!". Tradução de: "On ne saurait dire combien différens genres d'industrie économique ont multiplié sous toutes sortes de matières, et jeté dans la circulation, des ornemens devenus insignifians par leur multiplicité même. Combien des sphinxs, de lions, d'aigles, de vases, de trophées, de candélabres, de trépieds, d'autels, de caducées, de carquois, de couronnes, de branches de laurier, etc. qui ne deviennent qu'on remplissage fastidieux, et ne jouent plus dans les édifices d'autre rôle que celui des broderies sur les étoffes!". QUATREMÈRE DE QUINCY, Dictionnaire historique d'architecture, 1832, Première Tome, op.cit., p.307.

$585 \mathrm{Na}$ obra Wissenschaft, Industrie und Kunst (op.cit.), de 1852.

586 "...it [ornament] was an attached layer of the same material and achieved with the same tools as architecture". PAYNE, From ornament to object, op.cit., p.8

${ }^{587}$ Segundo van Zanten, em princípios do século XIX, os estudantes da Académie - cuja supervisão era de responsabilidade de Quincy - estudavam arquitetura, mais particularmente as ordens clássicas, seguindo métodos da escultura, em que o modelamento das formas era conseguido mediante um tratamento monocromo de luz e sombra. Isto se deve ao fato de Quincy sustentar a tradicional associação entre ordens
} 
meio intelectual alemão, que desde fins do século anterior vinham progressivamente reconhecendo a importância das características dos materiais para estética e o sentido da Arquitetura, ${ }^{588}$ Semper postula o Ornamento como algo fundamentalmente material, tridimensional e colorido. Matéria, técnica e cor condicionam seus sentidos e sua aparência final. No entanto, por outro lado, pode-se dizer que Semper reelabora os vínculos do Ornamento com a teoria clássica da Arquitetura, a qual teve como derradeiro bastião o autor do Dictionnaire. O Ornamento é o que caracteriza o Estilo de uma obra arquitetônica e o que evidencia sua ordem, ordem que é sustentada pelo teórico hamburguês mediante uma unidade imprescindível entre beleza, aspectos estruturais e de propósito ou utilidade da obra.

Talvez a grande contribuição de Semper à teoria da Arquitetura e das artes de um modo geral tenha sido a de reconhecer o Ornato com elemento da cultura, existente desde os primórdios da humanidade. Como o impulso artístico é uma faculdade inerente ao homem e implica em uma tentativa de reproduzir a ordem do universo, em última instância, como coloca Papapetrus, em Semper, todo artefato fabricado pelo homem, em todos os tempos e em todas as culturas, é um Ornamento. ${ }^{589}$

O legado da teorização semperiana do Ornamento, apesar de direta ou indiretamente profícuo, não teve os desdobramentos que talvez o autor esperasse, haja vista a pretensão e o fôlego teórico do Der Stil. O historiador vienense Alois Riegl, já em seu primeiro livro, Stilfragen (1893) - obra que coloca em questão os dois principais temas do Der Stil, Estilo e Ornamento -, apesar de referenciar-se em alguns pressupostos do colega, empenha-se em superar os próprios fundamentos do conceito de Ornamento em Semper. Nesta obra, Riegl não somente procura demonstrar a insubmissão do Ornamento aos condicionantes técnicos e materiais, ${ }^{590}$ como também concebe-o tendo vida histórica autônoma, ou seja, como independente do meio cultural, além de esvaziado de conteúdo simbólico.

e corpo humano. VAN ZANTEN, David. Architectural polychromy life in architecture. In: MIDDLETON, Robin (ed.) The Beaux-Arts and the nineteenth-century French architecture. London: Thames and Hudson, 1982, p.197-215.

588 Conferir nota 388

589 PAPAPETRUS, World ornament, op.cit.

590 RIEGL, Problems of style..., op.cit. 
Mas, não obstante esta e outras investigações do estudioso de Viena que evidenciem interlocuções - mesmo que críticas - com a teoria do Ornamento de Semper, o interesse de Riegl nesse assunto é dirigido à formação do campo da História da Arte. ${ }^{591} \mathrm{Na}$ área da Arquitetura propriamente, a defesa semperiana do Ornato foi literalmente sentenciada. $\mathrm{O}$ arquiteto Hermann Muthesius, um dos entusiastas pioneiros na constituição de uma arquitetura moderna, já havia defendido que a forma não ornamentada também tinha valor artístico ${ }^{592}$ quando Adolf Loos, em 1908, publica Ornament und Verbrechen, ensaio que refuta a legimitidade do Ornamento na vida do homem moderno, ${ }^{593}$ e que, como coloca Alina Payne, teve o efeito de uma "auto-proclamação do modernismo em sua forma mais lúcida e concisa". 594

Pode-se dizer que o processo de superação do Ornamento é consumado no momento em que o Modernismo assume um consenso internacional na segunda década do século vinte, momento que é bem ilustrado no título da publicação associada à exposição da Werkbund de 1924, Die Form ohne Ornament 595 e cujo tema é de certa forma retomado na publicação de Le Corbusier do ano seguinte, L'art décoratif d'aujourd'hui, que trouxe a célebre máxima: "a arte decorativa moderna não possui decoração"596. Nesta perspectiva, bastante questionável, a virtude não está no Ornamento, como o propunha Semper, mas em sua excomunhão.

\footnotetext{
591 É importante ter em mente que Riegl e outros empenhavam-se em constituir a História da Arte como disciplina autônoma. Tal processo exigiu a negociação com outros campos e atores, daí a referência constante a Gottfried Semper - renomado arquiteto da época, cujos escritos tangenciavam uma série de outras disciplinas - para legitimar certas noções, mas também a necessidade de se distinguir de seus escritos e da própria Arquitetura.

592 Trata-se da publicação Stilarchitektur und Baukunst, de 1902, na qual o autor sustenta também que "o impulso fatal pelo ornamento fez surgir toda a angústia artística contemporânea". Tradução de "the fateful impulse for ornament conjured up the entire contemporary artistic distress". MUTHESIUS, Style Architecture and Building-Art..., op.cit., p.88.

593 LOOS, Adolf. Ornamento y delito y otros escritos. Trad. Lourdes Cirlot y Pau Pérez. Barcelona: Ed. Gustavo Gili, 1972.

594 "Modernism's self-proclamation in its most lucid and concise form". PAYNE, From ornament to object, op.cit., p.2.

595 Traduzida como "a forma sem ornamento", a publicação é uma documentação dos objetos expostos na exposição Die Form, organizada pela Werkbund em Stuttgart.

596 "I' art décoratif moderne n'a pas de décor". LE CORBUSIER. L'art décoratif d'aujourd'hui. Paris: Arthaud, 1980, p.84. Essa publicação de Le Corbusier acompanhou a exibição do pavilhão L'Esprit Nouveau, de Le Corbusier e Amédée Ozenfant na Exposition internationale des arts décoratifs et industriels modernes de 1925.
} 


\section{REFERÊNCIAS}

\section{BIBLIOGRAFIA DE GOTTFRIED SEMPER:}

\section{Manuscritos}

Geschichte der Baukunst, Manuscrito n.19, Semperarchiv an der ETH Zürich, 1834, fols.1-38.

Remarks upon artistic taste among the people and the means of its development, Manuscrito n.89, Semperarchiv an der ETH Zürich, 1853, fols.188.

For some months I had the honour to read in this room a paper..., Manuscrito n.124, Semperarchiv an der ETH Zürich, 1853, fols.1-28.

Exzerpte und Notizen zu Böttichers "Tektonik der Hellenen", Manuscrito n.150, Semperarchiv an der ETH Zürich, 1853, fols 1-44.

\section{Artigos e livros}

Vorläufige Bemerkungen über bemalte Architectur und Plastik bei den Alten. Altona: Johann Friedrich Hammerich, 1834.

Die vier Elemente der Baukunst. ein Beitrag zur vergleichenden Baukunde. Braunschweig: Vieweg und Sohn, 1851.

On the study of polychromy and its revival. In: FALKENER, Edward. The museum of classical antiquities: a quarterly journal of architecture and the sister branches of classic art. London: John W. Parker and Son,1851, pp.228-246.

Wissenschaft, Industrie und Kunst. Vorschläge zur Anregung nationalen Kunstgefühles, bei dem Schlusse der Londoner Industrie-Ausstellung. Braunschweig: Vieweg und Sohn, 1852.

London lecture of November 11, 1853. In: PELLIZZI, Francesco (ed.). RES: Anthropology and Aesthetics, New York, London: Cambridge University Press, 1983, v. 6, pp.5-31.

London lecture of autumn 1854: On architectural symbols. In: PELLIZZI, Francesco (ed.). RES: Anthropology and Aesthetics, New York, London: Cambridge University Press, 1985, v. 9, pp.61-67.

Über die formelle Gesetzmassigkeit des Schmucks und dessen Bedeutung als Kunstsymbol. Zürich: Meyer \& Zeller, 1856. 
Der Stil in den technischen und tektonischen Künsten, oder, Praktische Aesthetik. Ein Handbuch für Techniker, Künstler und Kunstfreund. Frankfurt: Verlag für Kunst und Wissenschaft, 1860, v.l.

Der Stil in den technischen und tektonischen Künsten, oder, Praktische Aesthetik. Ein Handbuch für Techniker, Künstler und Kunstfreund. München: Friedrich Bruckmann's Verlag, 1863, v.II.

Über Baustyle. Zurich: Druck und Verlag von Friedrich Schultess, 1869.

The basic elements of architecture (Introduction to "Comparative Building Theory"). In: HERRMANN, Wolfgang. Gottfried Semper: in search of architecture. Cambridge, Massachusetts: MIT Press, 1984, pp.196-203.

The Attributes of Formal Beauty. In: HERRMANN, Wolfgang. Gottfried Semper: in search of architecture. Cambridge, Massachusetts: MIT Press, 1984, pp.219244.

The four elements of architecture and other writings. Trans. Harry Francis Mallgrave and Wolfgang Herrmann. Cambridge: Cambridge University Press, 1989.

Style in the Technical and Tectonic Arts; or Practical Aesthetics. 2 vol. Trans. Harry Francis Mallgrave and Michael Robinson. Los Angeles: Getty Research Institute, 2004.

Semper: El estilo. (El estilo em las artes técnicas y tectónicas, o, Estética práctica y textos complementários). Trad. Juan Ignacio Azpiazu. Buenos Aires: Azpiazu ediciones, 2013.

Escritos fundamentales de Gottfried Semper. El fuego y su protección. Edición y prólogo de Antonio Armesto. Trad. Manuel García Roig Barcelona: Fundación Arquia, 2014.

\section{BIBLIOGRAFIA GERAL}

ALBERTI, Leon Battista. Da arte de construir. Tratado de Arquitetura e Urbanismo. Trad. e Org. Sérgio Romanelli. SP: Hedra, 2012.

ALEXANDRE JÚNIOR, Manuel. Prefácio. In: ARISTÓTELES. Retórica. Tradução de Manuel Alexandre Júnior, Paulo Farmhouse Alberto e Abel do Nascimento Pena. Lisboa: Imprensa Nacional - Casa da Moeda, 2005.

. Introdução. In: ARISTÓTELES. Retórica. Tradução de Manuel Alexandre Júnior, Paulo Farmhouse Alberto e Abel do Nascimento Pena. Lisboa: Imprensa Nacional - Casa da Moeda, 2005. 
ALGAROTTI, Francesco. Saggio sopra l'Architettura. Veneza: Stamperia Graziosi, 1784.

ARGAN, Giulio Carlo. Lo artístico y lo estético. Madrid: Casimiro Libros, 2010.

AZEVEDO, Ricardo Marques de. Antigos modernos. Estudo das doutrinas arquitetônicas nos séculos XVII e XVIII. SP: Fauusp, 2009.

Arquitetura falante. In: MUHAN, Adma; LAUDANNA, Mayra;

BAGOLIN, Luiz A. (org.) Retórica. SP: Annablume; IEB, 2012, pp.45-62.

Preceptivas artísticas. In: AZEVEDO, Ricardo Marques de;

D’Agostino, Mário Henrique Simão; Loewen, Andrea Buchidid. Preceptivas Arquitetônicas. São Paulo: Annablume, 2015, pp.11-14.

. Ordens de arquitetura. In: AZEVEDO, Ricardo Marques de;

D’AGOSTINO, Mário Henrique Simão; LOEWEN, Andrea Buchidid. Preceptivas Arquitetônicas. São Paulo: Annablume, 2015, pp.205-223.

As doutrinas rigoristas do século XVIII. In: AZEVEDO, Ricardo Marques de; D’Agostino, Mário Henrique Simão; Loewen, Andrea Buchidid. Preceptivas Arquitetônicas. São Paulo: Annablume, 2015, pp.275-295.

AZEVEDO, Ricardo Marques de; D’AGOSTINO, Mário Henrique Simão; LOEWEN, Andrea Buchidid. Apresentação. In: AZEVEDO, Ricardo Marques de; D’Agostino, Mário Henrique Simão; Loewen, Andrea Buchidid. Preceptivas Arquitetônicas. São Paulo: Annablume, 2015, pp.7-9.

AZPIAZU, Juan Ignacio. Prefacio. In: Semper. El estilo. (El estilo em las artes técnicas y tectónicas, o, Estética práctica y textos complementários). Trad. Juan Ignacio Azpiazu. Buenos Aires: Azpiazu ediciones, 2013, pp. IV-XI.

BARTHES, Roland. A retórica antiga. Tradução de Lede Pinto Mafra Fruzun. In: COHEN, Jean et. al. Pesquisas de Retórica. Rio de Janeiro: Ed. Vozes, 1975, pp.147-221.

BELL, Quentin, The Schools of Design. London: Routledge \& Kegan Paul, 1963.

BENEVOLO, Leonardo. História da arquitetura moderna. SP: Ed. Perspectiva, 1998.

BERLAGE, Hendrik Petrus. "Thoughts on Style in Architecture" in:

MALLGRAVE, Harry Francis (ed.). Hendrik Petrus Berlage: Thoughts on Style, 1886-1909.

BLETTER, Rosemarie H. On Martin Fröhlich's Gottfried Semper. In:

Oppositions, n.4, outubro de 1974, p.146-153. 
BÖTTICHER, Karl. Die Tektonik der Hellenen. Potsdam: Verlag von Ferdinand Riegel, 1852, v.1.

CALLEBAT, Louis. Rhetorique et Architecture dans le De Architecture de Vitruve. In : GROS, Pierre. (a cura di) Le Profect de Vitruve. Object, Destinataires et Réception du De Architecture, Acte de Colloque International (Rome, 26-27/03/1993), Rome, 1994.

CASSIRER, Ernst. A filosofia do lluminismo. Trad. Álvaro Cabral. Campinas: Editora da Unicamp, 1992.

Lisboa, 2004.

Tragédia da cultura. In: SERRÃO, Adriana V. (Ed.). Philosophica, n.23,

CHESTNOVA, Elena. 'Ornamental design is... a kind of practical science'. Theories of ornament at the London School of Design and Department of Science and Art. In: Journal of Art Historiography, n.11, 2014, pp.1-18. Disponível em https://arthistoriography.files.wordpress.com/2014/11/chestnova.pdf. Acesso em 20.out.2015.

CHIAPPETTA, Angélica. Uma arte da memória do século XVII. In: MUHAN, Adma; LAUDANNA, Mayra; BAGOLIN, Luiz A. (org.) Retórica. SP: Annablume; IEB, 2012, pp.63-89.

CICERO. De oratore; or on the character of the orator. In: CICERO. Cicero on oratory and orators. Trans. J. S. Watson. NY: Harper and Brothers, 1875, pp.5261.

COLLINS, Peter. Los ideales de la arquitectura moderna; su evolución (17501900). Barcelona: Ed. Gustavo Gili, 1977.

COLQUHOUN, Alan. Três tipos de historicismo. In: tradição clássica: 1980-1987. SP: Cosac \& Naify, 2004, pp.23-37. Modernidade e

CUNHA, Antônio Geraldo da [et.al.]. Dicionário Etimológico Nova Fronteira da Língua Portuguesa. RJ: Editora Nova Fonteira, 1982.

CURTIS, J.E., READE, J.E. (ed.) Art and empire. Treasures from Assyria in the British museum. London: British museum press, 1995.

D’AGOSTINO, Mário Henrique S. As palavras e as pedras. In: Desígnio: revista de história da arquitetura e urbanismo. Universidade de São Paulo. Faculdade de Arquitetura e Urbanismo. Área de concentração de pós-graduação. História e fundamentos da arquitetura e urbanismo. São Paulo: Annablume, - n.5 março de 2006, pp.39-44.

A beleza e o mármore. $\mathrm{O}$ tratado De Architectura de Vitrúvio e o Renascimento. SP: Annablume, 2010. 
. Vitrúvio, De Architectura. In: AZEVEDO, Ricardo Marques de;

D’Agostino, Mário Henrique Simão; Loewen, Andrea Buchidid. Preceptivas Arquitetônicas. São Paulo: Annablume, 2015, pp.15-38.

D’AGOSTINO, Mário Henrique Simão; LOEWEN, Andrea Buchidid. Retórica e Ornamento em Vitrúvio e Alberti. In: AZEVEDO, Ricardo Marques de; D'AGOSTINO, Mário Henrique Simão; LOEWEN, Andrea Buchidid, Preceptivas Arquitetônicas, op. cit., 2015, pp.89-108.

D'AVILER, Augustin Charles. Cours d'Architecture qui comprend les ordres de Vignole, avec des commentaires, les figures \& descriptions de ses plus beaux bâtiments, \& de ceux de Michel-Ange, plusieurs nouveaux desseins, ornemens \& préceptes concernant la distribution, la décoration, la matiere \& la construction des edifices, la maçonnerie, la charpenterie, la couverture, la serrurerie, la menuiserie, le jardinage \& tout ce qui regarde l'art de bâtir ; avec une ample explication par ordre alphabetique de tous les termes. Paris: chez Nicolas Langlois, 1691.

DURAND, Jean-Nicholas-Louis. Précis des leçons d'architecture donnés à L'École Polytechnique. Paris : chez l'auteur, à l'École Polytechnique, 1802, Premier volume.

ECK, Caroline van. Classical rhetoric and the visual arts in early modern Europe. Cambridge : Cambridge university press, 2007.

. Figuration, tectonic and animism in Semper's Der Stil. In: The journal of architecture, volume 14, number 3, 2009, pp.325-337.

ELIADE, Mircea. Mitos, sonhos e mistérios. Lisboa: Edições 70, 2000.

. Mito e Realidade. Trad. Pola Civelli. São Paulo: Perspectiva, 2011.

FÉLIBIEN, André. Des principes de l'architecture, de la sculpture, de la peinture et des arts qui en dépendent, avec un dictionnaire des termes propes à chacun de ces arts. Paris : chez Jean-Baptiste Coignard, 1676.

FOUCAULT, Michel. As palavras e as coisas. Uma arqueologia das ciências humanas. Trad. Salma Tannus Muchail. São Paulo: Martins Fontes, 2000.

FRÖHLICH, Martin. Gottfried Semper. zeichnerischer Nachlass an der ETHZürich. Basel: Birkhäuser, 1974.

GEORGIADIS, Sokratis. Sempers schwierige Rückkehr aus dem zweiten Exil. In: Werk, Bauen + Wohnen, n.4, 1992, pp.61-2.

GIEDION, Sigfried. Espaço, Tempo e Arquitetura. O desenvolvimento de uma nova tradição. Trad. Alvamar Lamparelli. SP: Martins Fontes, 2004. 
GLEITER, Jörg. Rückkehr des Verdrängten. Zur kritischen Theorie des Ornaments in der architektonischen Moderne. Weimar: Universitätsverlag der Bauhaus-Universität Weimar, 2002.

. Ornament: the battleground of theory. In: GLEITER, Jörg (ed.) Zona \#4. Ornamento. Ritorno del represso. Bolzano: Facoltà di Design e Arti dela Libera Università di Bolzano, n.8, 2009, pp.14-18.

GNEHM, Michael. Stumme Poesie. Architektur und Sprache bei Gottfried Semper. Zürich: gta Verlag, 2004.

GOETHE, Johann Wolfgang von. Arte e artesanato. In: Escritos sobre arte. Introdução, tradução e notas de Marco Aurélio Werle. Sp: Imprensa oficial do estado de SP, 2008.

GRIMM, Jacob e Wilhem. Deutsches Wörterbuch (reprodução eletrônica do original de 1854). 33v. Munique: Universidade de Trier, 1984.

GROS, Pierre. Ornamentum chez Vitruve : le debat sur le décor architectural à la fin de l' epoque hellénistique. In : GROS, Pierre (org.) Vitruve et la tradition des traités d'Architecture - fabrica et ratiocinatio. Rome : Publications de l'école française de Rome, 2006, pp. 389-398. Disponível http://books.openedition.org/efr/2517. Acesso em 15.nov.2015.

. Voluptas chez Vitruve. In : Vitruve et la tradition de traités d'Architecture : fabrica et ratiocinatio. Rome : Publications de l'école française de Rome, 2006, pp.485-488. Disponível http://books.openedition.org/efr/2517. Acesso em 15.nov.2015.

. La notion d'ornamentum de Vitruve à Alberti. Perspective, Paris, 1, 2010, pp.130-136. Disponível em < http://perspective.revues.org/1226>. Acesso em 20.nov.2015.

HARATHER, Karin. Haus-Kleider. Zum Phänomen der Bekleidung in der Architektur. Wien/Koln/Wiemar: Böhlau, 1995.

HEIDEGGER, Martin. A origem da obra de arte. Trad. Idalina Azevedo e Manuel António de Castro. SP: Edições 70, 2010.

HERDER, Johann Gottfried. Escultura. Algunas observaciones sobre la forma y la figura a partir del sueño plástico de Pigmalión. Introd., trad. y notas de Vicente Jarque. València: universitat de València, 2006.

HERRMANN, Wolfgang.Gottfried Semper im Exil. Basel: Birkhäuser, 1978. Gottfried Semper: theoretischer Nachlass an der ETH-Zürich. Basel: Birkhäuser, 1981. 
. In exile: Semper in Paris and London. In: Gottfried Semper: in search of architecture. Cambridge, Massachusetts: MIT press, 1984, pp.9-83.

. Semper and the archeologist Bötticher. In: Gottfried Semper: in search of architecture. Cambridge, Massachusetts: MIT press, 1984, pp.139152.

Semper's position on the primitive hut. In: Gottfried Semper. in search of architecture. Cambridge, Massachusetts: MIT press, 1984, pp.165173.

. Intoduction. In: HÜBSCH, Heinrich et.al. In What Style Should We Build? The German Debate on Architectural Style. Trans. Wolfgang Herrmann. Santa Monica: Getty Center for the History of Arts and the Humanities, 1992, pp.1-60.

HILDEBRAND, Sonja. Concepts of creation: historiography and design in Gottfried Semper. In: WOODFIELD, Richard (ed.). Journal of art historiography, n.11, Dec. 2014.

HOUZE, Rebecca. Hungarian nationalism, Gottfried Semper and the Budapest Museum of Applied Art. In: Studies in the decorative arts. Chicago: The university of Chicago press, 2009, v.16, n.2, pp.7-38.

HÜBSCH, Heinrich. In welchem Style sollen wir bauen ? Karlsruhe: Chr. Fr. Müller Hofbuchhandlung und Hofbuchdruckeren, 1828.

HÜBSCH, Heinrich et.al. In What Style Should We Build? The German Debate on Architectural Style. Trans. Wolfgang Herrmann. Santa Monica: Getty Center for the History of Arts and the Humanities, 1992.

HUCHET, Stéphane. Horizonte tectônico e campo "plástico" - de Gottfried Semper ao grupo Archigram. Pequena genealogia fragmentária. In: MALARD, Maria Lúcia (org). Cinco textos sobre arquitetura. BH: Editora da UFMG, 2005, pp.169-233.

HVATTUM, Mari. Gottfried Semper and the problem of historicism. Cambridge: Cambridge University Press, 2004.

. Crisis and correspondence: style in the nineteenth century.

Architectural Histories, n.l, vol.I,pp.1-8, 2013. Disponível em

http://journal.eahn.org/articles/10.5334/ah.an/. Acesso em 4.abr.2016.

IRMSCHER, Günter. Kleine Kunstgeschichte des europäischen Ornaments seit der frühen Neuzeit (1400-1900). Darmstadt: Wissenschaftliche Buchgesellschaft, 1984.

JONES, Owen. The grammar of ornament. London: Day \& Son, 1856. 
KANT, Immanuel. Crítica da Faculdade do Juízo. RJ: Ed. Forense Universitária, 2005.

KARGE, Hendrik. Projecting the future in German art historiography of the nineteenth century: Franz Kugler, Karl Schnaase and Gottfried Semper. In: WOODFIELD, Richard (ed.). Journal of art historiography, n.9, Dec. 2013.

KLEMM, Gustav. Allgemeine Kulturgeschichte der Menschheit. Leipzig: Teubner: 1843-1852.

KOSELLECK, Reinhart. Futuro passado: contribuição à semântica dos tempos históricos. Trad. Wilma Patrícia Mass, Carlos Almeida Pereira. RJ:

Contraponto, Puc-Rio, 2006.

KOSSOVITCH, Leon. Tradição Clássica. In: Desígnio: revista de história da arquitetura e urbanismo. Universidade de São Paulo. Faculdade de Arquitetura e Urbanismo. Área de concentração de pós-graduação. História e fundamentos da arquitetura e urbanismo. São Paulo: Annablume, - n.5 março de 2006, pp.15-21.

KROLL, Frank-Lothar. Das Ornament in der Kunsttheorie des 19. Jahrhunderts. Hildesheim, Zürich, New York: Georg Olms Verlag, 1987.

KRÜGER, Mário. A escrita do De Re Aedificatoria de Leon Battista Alberti. In: AZEVEDO, Ricardo Marques de; D’AGOSTINO, Mário Henrique Simão; LOEWEN, Andrea Buchidid. Preceptivas Arquitetônicas. São Paulo: Annablume, 2015, pp.39-88.

LAUGIER, Marc-Antoine. Essai sur l'architecture.Paris: chez Duchesne, 1755.

LE CORBUSIER. L'art décoratif d'aujourd'hui. Paris: Arthaud, 1980.

LEONI, Claudio. Art, production and market conditions Gottfried Semper's historical perspective on commodities and the role of museums. In: WOODFIELD, Richard (ed.). Journal of art historiography, n.11, Dec. 2014.

LEOPOLD, J. Culture in comparative and evolutionary perspective: E. B. Tylor and the making of primitive culture. Berlin: Reimer: 1980.

LIMA, Clóvis Antônio Benedini. Ratio venustatis: razões da beleza nos livros I e III do De Architectura de Vitrúvio. 2015. 222p. Dissertação (Mestrado em Arquitetura e Urbanismo apresentado para a faculdade de Arquitetura e Urbanismo da Universidade de São Paulo), São Paulo, 2015.

LOEWEN, Andrea Buchidid. Lux pulchritudinis. Sobre beleza e ornamento em Leon Battista Alberti. SP: Annablume, 2012.

A beleza como Ornamento e os tratados de arquitetura do Renascimento. In: AZEVEDO, Ricardo Marques de; D’Agostino, Mário 
Henrique Simão; Loewen, Andrea Buchidid. Preceptivas Arquitetônicas. São Paulo: Annablume, 2015, pp.129-153.

LOOS, Adolf. Ornamento y delito y otros escritos. Trad. Lourdes Cirlot y Pau Pérez. Barcelona: Ed.Gustavo Gili, 1972.

MALLGRAVE, Harry Francis. The idea of style: Gottfried Semper in London. 1983. 375f. Tese (Doutorado em Arquitetura apresentado para as Graduate Faculties of the University of Pennsylvania), Filadélfia, 1983.

. Gustav Klemm and Gottfried Semper. the meeting of ethnological and architectural theory. In: RES: Anthropology and Aesthetics, New York, London: Cambridge university press, 1985, v.9, pp.68-79.

. Introduction. In: SEMPER, Gottfried. The four elements of architecture and other writings. Trans. Harry Francis Malgrave and Wolfgang Herrmann. Cambridge: Cambridge University Press, 1989.

. Gottfried Semper. architect of the nineteenth century. New Haven: Yale University Press, 1996.

. Modern architectural theory: a historical survey, 1673-1968.

Cambridge: Cambridge university press, 2005.

(ed.). Architectural theory, volume l: an anthology from Vitruvius to 1870. Oxford: Blackwell Publishing, 2006.

Animism, empathy and ornament in XIXth century Germanic theory. In: VARELA, Ariane Varela (org.) Ornamento, tra arte e design. Interpretazioni, percorsi e mutazioni nell'ottocento. Basel: Schwabe Verlag, 2013, pp.59-72.

MEMMO, Andrea. Elementi dell'Architettura lodoliana ossia l'arte del fabricare com solidità scientifica e com eleganza non capricciosa. Roma:Stamperia Pagliarini, 1786.

MORAES BARROS, Fernando R. de. Introdução. In: SCHELLING, F.W.J. Sobre a relação das artes plásticas com a natureza. Introd., trad. e notas Fernando R. de Moraes Barros. BH: Ed. UFMG, 2011, pp.7-26.

MORITZ, Karl Philipp. Versuch einer Vereinigung aller schönen Künste und Wissenschaften unter dem Begriff in sich selbst Vollendeten. In: Berlinische Monatsschrift, vol.5, 1785, pp.225-30.

1793.

Vorbegriffe zu einer Theorie der Ornamente. Berlin: Karl Matz-Dorff's,

MÜLLER, Karl O. Handbuch der Archäologie der Kunst . Breslau: Josef Max und Komp Verlag, 1830. 
MUTHESIUS, Hermann. Style Architecture and Building-Art, transformations of architecture in the nineteenth century and its present conditions. Trans.

Stanford Anderson. Los Angeles: Getty Research Institute, 1994.

OCÓN FERNÁNDEZ, María. Ornament und Moderne. Theoriebildung und Ornamentdebatte im deutschen Architekturdiskurs (1850-1930). Berlin: Dietrich Reimer Verlag, 2004.

OECHSLIN, Wagner. Stilhülse und Kern: Otto Wagner, Adolf Loos und der evolutionäre Weg zur modernen Architektur. Zurich: gta Verlag, 1994.

Gottfried Semper und Jacob Burckhardt: der unterschiedliche Blick auf die Renaissance. In: BEYER, Andreas; TÖNNESMANN, Andreas; MARKSCHIES, Alexander (Hrsg.) Zeitschrift für Kunstgeschichte. Müncher: Deutscher Kunstverlag, 2009, n.72, 1, pp.99-110.

OESTERLE, Günther. Gottfried Semper: la destruction et la réactualisation du classicisme. In: Revue germanique international (trad. Klaus Briegleb), n.2, 1994, pp.59-72

ORELLI-MESSERLI, Barbara von. Gottfried Semper (1803-1879). Die Entwürfe zur dekorativen Kunst. Petersberg: Michael Imhof Verlag, 2010.

PAPAPETRUS, Spyros. World ornament. The legacy of Gottfried Semper's 1856 lecture on adornment. In: PELLIZZI, Francesco (ed.). RES: Anthropology and Aesthetics, New York, London: Cambridge University Press, 2010, v.57/58, pp.309-329.

PATETTA, Luciano. Los revivals en arquitectura. In: ARGAN, Giulio Carlo et al. El pasado en el presente: el revival en las artes plásticas, la arquitectura, el cine y el teatro. Barcelona: Ed. Gustavo Gili, 1977, pp.129-163.

PAYNE, Alina. The architectural treatise in the Italian Renaissance.

Architectural invention, ornament and literary culture. Cambridge: Cambridge university press, 1999.

Ut poiesis architectura. Tectonics and poetics in architectural criticism circa 1570. In: KUTTNER, Ann; PAYNE, Alina; SMICK, Rebekah (ed.). Antiquity and its interpreters. Cambridge: Cambridge university press, 2000, pp.145-158.

Reclining bodies: figural ornament in Renaissance architecture. In: DODDS, George; TAVENOR, Robert (ed.). Body and Building. Essays on the changing relation of body and architecture. Cambridge, London: the MIT Press, 2002, pp.95-113.

. L'ornement architectural: du language classique des temps modernes à l'aube du XXe siècle. Perspective [En ligne], n.1, 2010, p.77-96. Disponível em http://perspective.revues.org/1220. Acesso em 5.nov.2015. 
From ornament to object: genealogies of architectural modernism. New Haven: Yale University Press, 2012.

PEREIRA, Isidro S.J. Dicionário Grego-Português e Português-Grego. Porto: Livraria Apostolado da Imprensa, 1969.

PERRAULT, Claude. Les dix livres d'Architecture de Vitruve corrigez et traduits nouvellement en François avec des notes et des figures. Paris: chez JeanBaptiste Coignard, (1673) 1684.

PEVSNER, Nikolaus. Os pioneiros do desenho moderno: de William Morris a Walter Gropius. SP: Martins Fontes, 1980.

. High Victorian design. In: Studies in art, architecture and

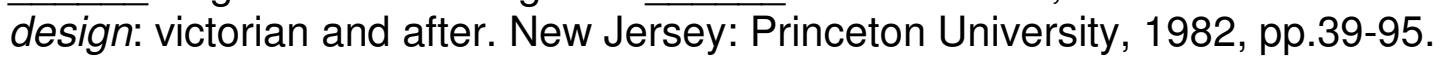

QUATREMÈRE DE QUINCY, Antoine-Chrysostôme. Dictionnaire historique d'architecture, comprenant dans son plan les notions historiques, descriptives, archaeologiques, biographiques, théoriques, didactiques et practiques de cet art. Paris: Librairie d'Adrien Le Clère et Cie, 1832, Première et Second Tome.

QUITZSCH, Heinz. La visione estetica di Semper. Trad. Daria Rescaldani. Jaca Book: Milano, 1991.

REDGRAVE, Richard. Supplementary report on design. In: EXHIBITION OF THE WORKS OF INDUSTRY OF ALL NATIONS. Reports by the juries on the subjects in the thirty classes into which the exhibition was divided. London: William Clowes and Sons, 1852.

RIEGL, Alois. Problems of style: foundations for a history of ornament. Trans. Evelyn Kain. Princeton: Princeton University Press, 1992.

ROBERTSON, D. S. Arquitetura grega e romana. Trad. Julio Fischer. SP: Martins Fontes, 2014.

ROSA, Elis Piera. O símbolo e a alegoria nos textos teóricos de Goethe (de 1772 a 1798). 2012. 161f. Dissertação (Mestrado em estudos Literários apresentado para a Faculdade de Ciências e Letras da Universidade Estadual Paulista Júlio de Mesquita Filho -UNESP), Araraquara, 2012.

RUMOHR, Karl Friedrich von. Italienische Forschungen. Berlin: Nicolai Verlag, vol I, 1827.

RYKWERT, Joseph. Inheritance or tradition? In: (ed.). Architectural Design, vol.49, n.5-6, London, 1979, pp.2-6.

Gottfried Semper and the conception of style. In: The necessity of artifice: ideas in architecture. New York: Rizzoli, 1982. 
A casa de Adão no paraíso: a ideia da cabana primitiva na história da arquitetura. Trad. Ana Gabriela G. de Lima, Anat Falbel, Margarida Goldsztajn e Mário Henrique S. D’Agostino. São Paulo: Perspectiva, 2003.

. A coluna dançante: sobre a ordem na arquitetura. Trad. Andrea Buchidid Loewen, Maria Cristina Guimarães, Cassia Naser. São Paulo: Perspectiva, 2015.

SCHAFTER, Debra. The order of ornament, the structure of style. Theoretical foundations of modern art and architecture. Cambridge: Cambridge University Press, 2003.

SCHÜTTE, Ulrich. Ordnung und Verzierung: untersuchungen zur deutschsprachigen Architekturtheorie des 18.Jahrhunderts. Braunschweig, Wiesbaden: Friedrich Vieweg und Sohn, 1986.

SCHWARZER, Mitchell. Ontology and representation in Karl Bötticher's theory of tectonics. In: Journal of the Society of Architectural Historians, Vol. 52, No. 3, Set., 1993, pp. 267-280.

SUMMERSON, John. A linguagem clássica da arquitetura. SP: Martins Fontes, 2006.

TODOROV, Tzvetan. Teorias do Símbolo. Tradução Enid A. Dobránszky. Campinas, SP: Papirus, 1996.

TOGNON, Marcos. Arquitetura, corpo e tradição clássica: ilustrar Vitrúvio. In: Desígnio: revista de história da arquitetura e urbanismo. Universidade de São Paulo. Faculdade de Arquitetura e Urbanismo. Área de concentração de pósgraduação. História e fundamentos da arquitetura e urbanismo. São Paulo: Annablume, - n.3 março de 2005, pp.45-52.

UNGUREANU, Cosmin. Sia funzion la rappresentazione. Carlo Lodoli and the crisis of architecture. RIHA Journal, n.18, 21 march 2011, pp.1-25.

VAN ZANTEN, David. Architectural polychromy life in architecture. In: MIDDLETON, Robin (ed.) The Beaux-Arts and the nineteenth-century French architecture. London: Thames and Hudson, 1982, p.197-215.

VÁRZEAS, Marta. Introdução. In: LONGINO, Dionísio. Do sublime. Trad., introdução e comentário Marta Isabel de O. Várzeas. SP: Annablume, 2015.

VENTURI, Lionello. Historia de la crítica de arte. Barcelona: Debolsillo, 2004.

VIOLLET-LE-DUC, Eugène-Emmanuel. Dictionnaire raisonné de l' architecture française du XIe au XVesiècle. Paris: A. Morel éditeur, 1866, vol.8.

VITRÚVIO. Tratado de Arquitetura. Tradução, introdução e notas M. Justino Maciel. SP: Martins Fontes, 2007. 
WERLE, Marco Aurélio. Apresentação. In: BATTEUX, Charles. As Belas-Artes reduzidas a um mesmo princípio. Trad. Natalia Maruyama e Adriano Ribeiro. SP: Imprensa oficial do estado de SP, 2009.

WIGLEY, Mark. White walls, designer dresses: the fashioning of modern architecture. Cambridge: MIT Press, 1995.

WINCKELMANN, Johann Joachim. Historia del arte em la Antigüedad. Trad. Manuel Tamayo Benito. Madrid: Ed. Aguilar, 1955.

WITTKOWER, Rudolf. La arquitectura en la edad del Humanismo. Buenos Aires: Editorial Nueva Visión, 1958.

WORNUM, Ralph. The exhibition as a lesson in taste. In: THE CRYSTAL PALACE EXHIBITION. ILLUSTRATED CATALOGUE - LONDON, 1851. New York: Dover publication, 1970.

ZACZEK, lain. Introdução [à edição brasileira da Grammar]. In: JONES, Owen. A gramática do ornamento: ilustrado com exemplos de diversos estilos de ornamento. Tradução de Alyne A. Rosenberg. SP: Ed. Senac São Paulo, 2010.

ZEISING, Adolf. Neue Lehre von den Proportionen des menschlichen Körpers: aus einem bisher unerkannt gebliebenen, die ganze Natur und Kunst durchdringenden morphologischen Grundgesetze entwickelt und mit einer volständigen historischen Uebersicht der bisherigen Systeme begleitet. Leipzing: Rudolph Weigel, 1854.

Ästhetische Forschungen. Frankfurt an Main: Verlag von Meidinger Sohn und Comp., 1855.

ZEISING, Andreas. Haus und Herd: Wagner, Semper und die Urhütte. In: ZEISING, Andreas; IMORDE, Joseph (Hrsg.) Wahn und Wirkung. Perspektiven auf Richard Wagner. Siegen: Universitätsverlag Siegen, 2014; 